Crucible in the Classroom: The Freedpeople and Their Teachers

Charlottesville, Virginia, 1861-1876

Lauranett Lorraine Lee

Richmond, Virginia

B.A., Mundelein College, 1985

M.A., Virginia State University, 1993

A Dissertation presented to the Graduate Faculty of the University of Virginia in Candidacy for the Degree of

Doctor of Philosophy

Department of History

University of Virginia

May 2002

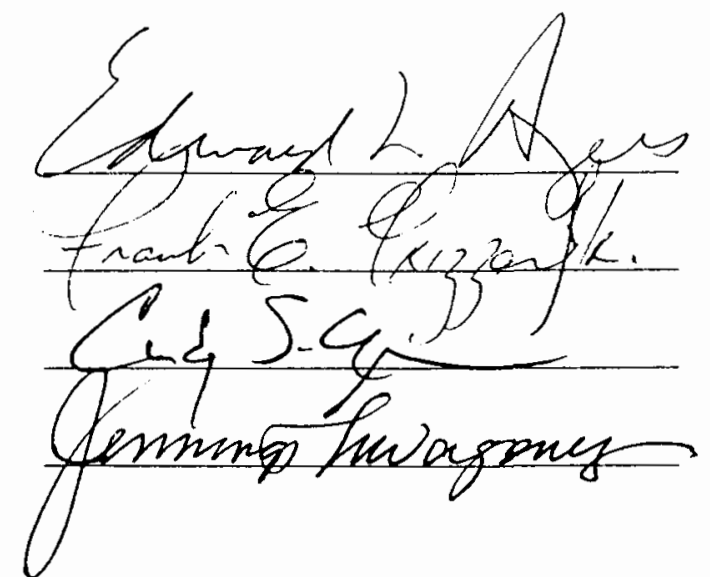




\author{
Abstract \\ Crucible in the Classroom: The Freedpeople and Their Teachers \\ Charlottesville, Virginia, 1861-1876
}

This study examines connections between emancipation, education, and identity. It explores the impact of freedom by recovering the daily lives of African Americans and their teachers in Charlottesville, Virginia, between 1861 and 1876. Both freedpeople and teachers learned to reshape their private aspirations while making sacrifices and concessions. The papers of two teachers sponsored by the New England Freedmen's Aid Society, Philena Carkin and Anna Gardner, provide the foundation for this study.

Three studies in particular inform my investigation. Rehearsal for Reconstruction (1964) by Willie Lee Rose examines the people of Port Royal at a crucial moment in American history. Lawrence Levine discusses the belief and value systems of enslaved people in Black Culture and Black Consciousness (1977). Leon Litwack's Been in the Storm So Long (1979) addresses the freedpeople's struggles from a regional perspective. These studies illuminate the paths freedpeople walked as they moved toward a new way of being in the world.

Exploring the world behind the words, asking questions of the sources, and listening to the multiple answers that arise became the methodology upon which this study was founded. My intent is to recover the daily devotion to freedom. Trailing the freedpeople and their teachers as they move about Charlottesville, looking at their local world when more people began to have new opportunities, 
and considering the link between education and identity offers a great deal of room to roam.

Moving beyond an examination of race, class, and gender, this study examines the era in terms of reconstructing the self. Both freedpeople and female schoolteachers willingly built new lives for themselves. My focus on a small group of people recovers both collective and individual distinctions within the emancipatory experience. Hence, this study is a process of seeing individuals with memories, dreams, hopes, and fears. 
TABLE OF CONTENTS

Part I

Chapter One: Background 1

Chapter Two: "Envisioning Hope 19

Chapter Three: The Enemy's Territory 42

Chapter Four: Harvesting the Future $\quad 70$

Part II

Introduction to the Papers of Philena Carkin 105

$\begin{array}{ll}\text { Editorial Note } & 107\end{array}$

$\begin{array}{ll}\text { The edited letters of Philena Carkin } & 108\end{array}$

Appendix I: The Reminiscences of Philena Carkin 158

Appendix II: Report on Prominent Whites and Freedmen 252

$\begin{array}{ll}\text { Bibliography } & 257\end{array}$ 


\section{Dedications}

I am thankful to my God and all my ancestors for bringing me on this path even when I kicked and screamed. For nine years I have delved into southern waters; now, I feel as if I have come up for a long, cool breath of air. Through it all many good people have sustained me. I have much admiration and respect for my advisor, Edward Ayers, who read every draft and commented accordingly. My advisor from Virginia State University, Edgar Toppin, not only encouraged me to pursue a doctorate, he also encouraged me to stick with it. The love and prayers of my parents, Clarence and Gloria Lee, have been constant. I am also grateful to my siblings, especially "Mann" and Jacqueline who endured my late night calls for computer help as well as my last minute requests for loans. My nephews Travon, Brandon, and Christopher, and my niece, Lorraine, have patiently waited for me to spend more time with them. My goddaughters, Keisha and Lauren, have been equally patient. My extended family, particularly my aunt Dora Walker and my cousin Simon Harris, extended support throughout this entire process.

I am thankful to my friends who offered assistance in a variety of ways: Pamila Gant, Betsey Brinson, Kay Peaslee, Debbie Usry, Gayle Schulman, Patricia Click, Beth O’Leary, Gail Neave, Barbara Bair, Dianne Swann-Wright, Liz Cherry Jones, Bill and Iva Condrey, Robert Morehouse, Dorothy Cowling, Grace Lessner, Diana Westbrook, Bob Vernon, Marilyn Milio, Jane and Eugene Foster, Nell Painter, Leslie Middleton, Elsa Barkley Brown, Greg Kimball, Karen Butler, Lori Boyd, Martin and Jane Davis, Greg Echols, Glenda Gilmore, Greg French and his family, and Steve Haas.

I am grateful to Peg O'Brien at the Albemarle County Historical Society. I have much gratitude to all those at the Massachusetts Historical Society who made me feel welcome 
especially at Christmas time; I benefited from a Mellon fellowship there. Likewise, the Alicia Monti fellowship at the Boston Pubic Library helped me to conduct further research. Roberta Zonghi's staff was equally kind. I have also benefited from several other fellowships: the State Council of Higher Education for Virginia, Commonwealth Fellowship, the National Historic Publications and Records Commission, Documentary Editing Institute Internship; Association of Black Women Historians and Black Classic Press, Drusilla Dunjee Houston Award, and The University of Virginia, Graduate History Fellowship—thanks, Dean Robert Huskey and Professor Ayers.

My committee members, Cindy Aron, Frank Grizzard, and Jennings Wagoner, worked with me to make my dissertation defense an absolutely wonderful experience. Elizabeth Stovall, as well as Kathleen Miller, Lottie McCauley, and Ella Wood, the secretarial staff in the history department, always had a kind word and warm smile. They helped lighten the load, even until the very end. Doris Lamb in the Graduate Arts and Sciences office and Heidi Winters, Professor Ayers' assistant, always stayed calm in the midst of chaotic moments. Michael Plunkett, in special collections at Alderman Library and his staff, especially Regina Rush, helped me tremendously. I appreciate your assistance.

Thanks also go out to my former colleagues in the history department at Old Dominion University, especially Anne and Alan Harris. I also thank the wonderful staff and students. Gratitude also is extended to Charles Bryan at the Virginia Historical Society, who stayed in touch with me after I entered the Ph.D. program. James Kelly and Frances Pollard and her staff at VHS came to my rescue on several occasions. The Library of Virginia staff also helped me on numerous occasions.

To all these and more, I thank your for keeping me on my path. 


\section{Chapter One: Background}

Resolved - that we, the colored people of Charlottesville tender our sincere thanks to the Freedmen's Aid Society of Boston for the generous assistance it has rendered us by establishing a school in our midst and thereby laying the foundation of our education. ${ }^{1}$

Written on heavy paper with frayed corners, now yellowed and slightly stained, this message from the past with no date or names attached opens a doorway into nineteenth-century Charlottesville. Behind the forty-two words are stories about groups of people who challenged traditional ideas about race, region, and intellect.

This seemingly straightforward quotation raises several intriguing questions. Does this passage speak for all colored people of Charlottesville? What is the Freedmen's Aid Society of Boston? What is its history? How long was it active in Charlottesville? Who did it send to Charlottesville and in what capacity? What is the name of the school it established? When was the school established? How were the teachers treated by members of the Charlottesville community? In what ways did the students and their teachers change the larger community? Anticipating their rights as freed people, blacks began to reconstruct their lives prior to the Confederacy's demise. Their emancipation experience found its roots in spiritual, intellectual, and political realms.

\footnotetext{
${ }^{1}$ Massachusetts Historical Society, New England Freedmen's Aid Society Papers, catalogued with "Letters Received." The resolution was possibly made in 1875; in a letter written by Philena Carkin on June 21, 1875, she refers to a resolution.
} 
Exploring the world behind the words, asking questions of the sources and listening to the multiple answers that arise became the method upon which this study is founded. Trailing the freedpeople and their teachers as they move about Charlottesville, Virginia, looking at their local world when more people began to have new opportunities, and considering the link between identity, education, and self-definition offers a great deal of room to roam. This study focuses on the disfranchised in Mr. Jefferson's town, those who were excluded from Jefferson's vision of an educated citizenry, and those who were among the first to teach the disfranchised in a formal environment.

Located in the middle belt of the Appalachian uplands, Albemarle County rests approximately 70 miles east of Richmond and 120 miles southwest of Washington, D.C. The Blue Ridge Mountains border the western edge of the county while the Rivanna River, a navigable branch of the James River, is nestled within its borders. ${ }^{2}$ Both free blacks and slaves were enumerated in the 1790 census of Albemarle County, the first national census taken under the Constitution. By the middle of the eighteenth century, the Piedmont area had become larger, healthier, and more prosperous than the Tidewater area. Slaves were introduced into the Piedmont area from the time it was first settled. Some came directly from Africa but the majority came from the Tidewater area where

\footnotetext{
${ }^{2}$ Originally, an Indian village called Monasukapanough occupied a large area of land about a half mile above the Rivanna River. It was the home of the Saponi Indians, who were members of the large Monacan Confederacy. They also belonged to the Sioux language group. See David I. Busnell, Jr., "Evidences of Indian Occupancy in Albemarle County, Virginia," Smithsonian Miscellaneous Collections 89 (1933), 7-10. Charlton G. Holland, Jr., "Albemarle Before 1700," Magazine of Albemarle County History 9 (1949), 5-12. Hereafter cited as $\mathrm{MACH}$.
} 
many of the slaves were introduced in Virginia. ${ }^{3}$ By the middle of the

seventeenth century wealthy landowners passed legislation aimed at maintaining

their large numbers of chattel slaves. ${ }^{4}$ Initially, the proportion of slaves in the

population was smaller in the Piedmont than in the Tidewater area. Their

numbers rose rapidly to between 40 and 45 percent and remained in that range

for decades. As more enslaved women were brought into the area, the sex ratio

among slaves became nearly equal. As a consequence, family life among slaves

was an integral part of the area. Large numbers of slave children, strong family

ties, and extended kin networks in the slave quarters were common on Piedmont

plantations. In Albemarle County, less than 5 percent of the slaves were hired

out. $^{5}$

${ }^{3}$ John Hammond Moore, Albemarle: Jefferson's County, 1727-1976 (Charlottesville: Albemarle County Historical Society, 1976), 115, 118.

${ }^{4}$ Between 1801 and 1849 wealthy landowners were granted the power to appoint constables, assess and collect taxes, establish laws for the preservation of the peace, impose penalties, and restrain "dogs going at large" and "free Negroes, mulattoes, or slaves." Revised Ordinances of the Corporation of Charlottesville, Together With a Digest of the Acts of the General Assembly Relating To the Town of Charlottesville (Charlottesville: James Alexander, Printer, 1849), 4-11. ${ }^{5}$ Philip D. Morgan, "Slave Life in Piedmont Virginia, 1720-1800," in Carr, Morgan, and Russo, editors, Colonial Chesapeake Society (Chapel Hill: University of North Carolina Press, 1988), 433-84. Also see: Allan Kulikoff, "The Origins of Afro-American Society in Tidewater Maryland and Virginia, 1700-1790," William and Mary Quarterly 3d series, 35 (1978), 245 n. 49. Clement Eaton, "Slave-Hiring in the Upper South: A Step Toward Freedom" in The Mississippi Valley Historical Review (March 1960, vol. XLVI, no. 4), 663-678. Eaton found that although the percentage was relatively low in Albemarle, in Lynchburg, an important tobacco-manufacturing center, more than 50 percent of the slaves were hired. See page 674).

In the eighteenth century large stable plantations in the Tidewater broke up, agricultural production changed fundamentally, and black communities on old Tidewater holdings were dispersed to the Piedmont. Some argue that this caused a move from a local, family-based, African identity, to a more pan-Virginian, African-American identity. James Sidbury has a good discussion of the breaking up of the old Tidewater holdings and movement to the Piedmont, especially its effect on black consciousness. See Ploughshares into Swords: Race, Rebellion, and Identity in Gabriel's Virginia, 1730-1810 (Cambridge University Press, 1997). In Flight and Rebellion: Slave Resistance in Eighteenth-Century Virginia, Gerald Mullin analyzes the differences between African and native-born slaves. Especially see chapters 1-3. 
By 1810 both the enslaved and free black population in Albemarle County

exceeded 50 percent. A few blacks earned their living through skilled work. The Robert Scott family of father, mother, and three sons were described as "accomplished musicians."6 Other Charlottesville slaves were midwives, carpenters, and blacksmiths. Most blacks, however, were employed in agriculture. As small landholders turned to the production of tobacco, the number of slaves needed to work the land increased. ${ }^{7}$

By 1820, a small percentage of the free black population lived in communities on the outskirts of the town, most often in small close-knit units. One such place located north of Charlottesville was named Free State. Free blacks co-existed within a diverse population that included a large number of slaves as well as middling and elite whites. The presence of free blacks raised fears of rebellion and facilitated the founding of the Albemarle Auxiliary Colonization Society. Operating as a branch of the national organization, the group conducted fundraising activities to send the blacks among them back to Africa. ${ }^{8}$

\footnotetext{
${ }^{6}$ Phillip T. Drotning, A Guide to Negro History in America (Garden City, New York: Doubleday \& Company, Inc., 1968), 208; Dumas Malone, Jefferson and His Time: Volume Six: The Sage of Monticello (Boston: Little, Brown and Company, 1981), 402; Charlottesville Central Gazette, November 10, 1824.

${ }^{7}$ Allan Kulikoff, Tobacco and Slaves: The Development of Southern Cultures in the Chesapeake, 1680-1800 (Chapel Hill: University of North Carolina Press, 1986). By 1850 (and until 1859), the total number of hogsheads of tobacco produced in Albemarle more than tripled. The production of tobacco brought about other changes, too. Property ownership increased among small land owners, those whose acreage was valued at $\$ 1$ to $\$ 499$, and among those who owned acreage valued at $\$ 10,000$ or more. As a result of tobacco's prominence, home manufactures decreased. Virginians become more dependent on the North for finished goods. Corn growing declined among all groups except for middling producers. Anne Lenore Stauffenberg, "Albemarle County: 1850-1870: An Economic Survey Based on the U.S. Census" (University of Virginia, Masters Thesis, 1973), 15, 21-24, 41.

${ }^{8}$ John Hammond Moore, Albemarle: Jefferson's County, 1727-1976 (Charlottesville: Albemarle County Historical Society, 1976), 115, 118. Patricia Hickin, "Anti-slavery in Virginia, 1831-1861" (Ph.D. dissertation, University of Virginia, 1968). For classic definitions of class, class formation,
} 
Census records for 1850 indicate that 54 percent of white households owned at least one slave. Within the next ten years ownership of slaves increased 13 percent. The increase came from a sizable number of small farmers able to buy land and field hands. In 1860, Albemarle's black population of slaves and free blacks outnumbered whites. ${ }^{9}$

When the Civil War came, white males expressed their fears about the management and discipline of their slaves. One prominent planter, Thomas J. Randolph, petitioned for the exemption of an overseer on his plantation, explaining that "the mountains and a river frame an area of roughly nineteen miles in which 270 slaves and seventy nine white people live." Of the latter, "several had relocated, twelve were in the service, and two had volunteered." Furthermore, he estimated, "thirty (white) women and thirty (white) children remained." Others also protested the lack of exemptions for overseers. W. T. Early claimed that the state draft depleted the homefront of white males. The white inhabitants of the plantations were left defenseless and in the hands of slaves. Not only could this lead to economic problems, it might very well raise the specter of rebellion within their midst. ${ }^{10}$

and class consciousness see E. P. Thompson, The Making of the English Working Class (New York, 1963), 9-12. Albert J.Raboteau, "The Black Experience in Evangelicalism: The Meaning of Slavery in African-American Religion: Interpretive Essays in History and Culture, Timothy E. Fulop and Albert J. Raboteau. Regarding the American Colonization Society, Raboteau discusses the attitude and influence of black clergymen. See page 99.

${ }_{9}^{9}$ Manuscript returns, Forty Eighth Census, National Archives, Washington, D. C. See also, John Hammond Moore's Albemarle: Jefferson's County, 1727-1976 (Charlottesville: Albemarle County Historical Society, 1976), pp. 111-126. See also Suzane Lebsock, The Free Women of Petersburg: Status and Culture in a Southern Town, 1784-1860 (New York: W. W. Norton, 1984) for a discussion of women and land ownership.

${ }^{10}$ William Blair, Virginia's Private War: Feeding Body and Soul in the Confederacy, 1861-1865 (New York: Oxford, 1998), 46, 50. See W. T. Early to Honorable John Letcher, March 12, 1862, Executive Papers, Library of Virginia. 
Once the Civil War began, most of the white citizens of Albemarle entered the war wholeheartedly. One observer, R. T. W. Duke, Jr., later recalled that the tunics and trousers worn by members of the sons of Liberty and the Southern Guards were sewn in Charlottesville's Town Hall. The hall had become "a gigantic tailor shop and every tailor in town was there cutting out gray uniforms whilst the ladies basted them and sewing women sewed them up." The effects of the Civil War were felt throughout the county as well as in households. The effects were most evident in the community of Charlottesville as well as at the University of Virginia. All of Charlottesville's five churches had agreed to contribute their bells to make cannons. Individuals donated "hand-bells, fire fenders, candlesticks, preserving kettles, boilers, curtain rings, \&c - one lady sending in her engraved card-plates." 11

Albemarle became an important medical center for the Confederacy. By late August 1861, the Charlottesville community was "a vast hospital for the sick and wounded of our army." Local citizens opened their homes to nurse the soldiers. Duke, a young boy in the 1860 s, later recalled the work of citizens. "Nurses were very scarce and the ladies in the town each in turn helped to nurse." Creating a place for themselves and making a contribution to the Confederate cause helped white women stretch the traditional roles to which they previously had been bound; in this way they asserted their patriotism. "My mother had her regular

\footnotetext{
${ }^{11} \mathrm{MACH} 10$ (1950), 28-30. The MACH 22 (1964) issue focuses on the Civil War. It devotes fifteen articles to the war effort in Albemarle County. Herbert A. Thomas, Jr., "The Nineteenth Virginia Regiment, 1861-1865," MACH 25 (1967), 5-35.
} 
turn and occasionally I went with her."12 Oftentimes, children, both male and female, learned lessons of responsibility as a part of citizenship. They also saw the raw consequences of war. "I recall car-loads of wounded unloaded and figures of men, desperate-wounded carried on stretchers into the wards from the cars," Duke recalled. Joseph Jones, an expert on diseases and a major in the Confederate hospital department, calculated that the Charlottesville General Hospital admitted 21,540 cases between July 1861 and February $1865 .^{13}$ Charlottesville, however, because of its location, did not suffer the physical devastation that many other localities endured.

Two weeks after the war began the Charlottesville Baptist Church "held a special session." On April 29, 1861, the church minutes noted that the leaders of the church had decided "to consider the request of the colored members in the communication from Fairfax Taylor." ${ }^{14}$ Acting as a representative for some of the slaves and free blacks, Taylor was chosen most likely because he was his own man and because he also knew how to communicate on a level that whites respected. Taylor, "formerly a slave, freed by his own purchase could not only read and write, but also had "some knowledge of grammar." In addition, he was "well respected in the community"15

\footnotetext{
${ }^{12}$ Duke Family Papers, University of Virginia, Alderman Library, Special Collections.

${ }^{13}$ Chalmers L. Gemmill, "The Charlottesville General Hospital, 1861-1865," MACH vol. 22 (1964): 91-160. James O. Breeden, "Insights into the Medical Statistics of the Charlottesville General Hospital, 1861-1865," MACH vol. 30 (1972), 43-59.

${ }^{14}$ Minutes, Charlottesville Baptist Church, April 29, 1861.

${ }^{15}$ Report on Prominent Whites and Freedmen, March - May 1867, Miscellaneous Records, Records of the Assistant Commissioner for the State of Virginia, Bureau of Refugees, Freedmen, and Abandoned Lands, 1865-1869, Reel 67.
} 
Whether Taylor had written or actually spoken in church on that spring evening, we do not know. We do know that the "colored members" of the integrated church made a request to the officials to license Brother John Thompson Randolph to preach. Randolph, a white man, had come to the church in 1852 and had been added to a committee to instruct the black population of the church. The committee on which he served increased the black membership "considerably." Having had time to work with him and learn his ways, some of the 842 black congregants found in him an ally.

On March 16, 1862, less than a year after the initial request, the black congregants petitioned for the ordination of John Randolph. A month after his ordination the new minister reported that "the colored members had at their recent meeting requested him to make known to the church their desire to separate from this Church in order to form an independent African Church." A committee was appointed to determine the desires of the blacks congregants. One committee member relayed their petitions to the white congregants, stating, "the colored members of the Baptist church at Charlottesville respectfully ask of their brethren:

1 - that, they with the sanction of said brethren, obtain a place of worship for themselves to be held in trust for their use.

2 - that, henceforth they may be allowed to select their own Pastor, Deacons, clerk, Treasurer, and their delegates to the various Associations and in which they may obtain representation. 3 - that, they may have the right to decide all matters of membership and discipline according to Baptist usage; and in general to be independent of the White church so far as to the laws of the State and just views of expediency allow. 
4 - that, they be allowed to select the trustees to hold the property for them, with the understanding that the said trustees shall be the white members of the Charlottesville Baptist church. ${ }^{16}$

Their petition illuminates four areas of black ideology: a desire on the part of the petitioners to own communal property, the privilege of self-representation, independence from white control, and willingness to cooperate within the prevailing customs. Despite the freedpeople's request for self-selection, the committee recommended that a white representative be present at any associations where blacks gathered. Whether Farifax Taylor and the other members discussed or accepted this amendment is unknown. However, B.W. Snead, a white committee member, later recorded that "the petition of the colored brethren was granted." The parent church offered its basement as a meeting place until permanent arrangements could be made.

In the early spring of 1863 , the status of the black congregants was discussed again in a business meeting. Some of the black members questioned their place within the parent church. The free black members felt they had not received the respect due them. "The pastor, for the past year, uniformly discriminated against the free persons and those who acted with them, in favor of the slaves, who in the main quietly acquiesced." Finally, on April 20, 1864, "800 colored members

\footnotetext{
${ }^{16}$ Minutes, Charlottesville Baptist Church, April 20, 1863.
} 
were dismissed by letter, who formed the Delevan Church." ${ }^{17}$ The first three ministers of Delevan were white men selected by the parent church. ${ }^{18}$

The founding members of the Delevan Church perceived themselves as worthy of better treatment than they had been accorded. As a traditional form of political action, petitioning inverted the notion of black subordination and inferiority. Black members wanted more freedom than whites were willing to allow. The actions of the freedpeople are those of a people who understood the value of patronage ties and written documents. Ironically, blacks had initiated a fundamental change by using literacy, a powerful tool of the dominant class. They pushed the boundaries of traditional race relations even before slavery had crumbled. In various ways, the African American population asserted itself as the Civil War ground to a halt. In 1864 a union cavalry raid five miles northeast of Charlottesville left its mark with burned fences, missing stock, and runaway slaves.

In January 1865, the editor of the Charlottesville Chronicle, J. C. Southall, expressed disapproval after blacks held a social event in the town hall. "If some formal steps are not taken to put our servants on the basis of servants, no legislative act will be necessary to declare their emancipation." Southall recognized the erosion of the status quo as blacks stepped out of their place. "A class may be free long before their enfranchisement is announced on the statue

\footnotetext{
${ }^{17}$ On March 12, 1863, Dr. William F. Broaddus presided at his first business meeting of the Charlottesville Baptist Church. Jeffersonian Republican, July 2, 1879. The Delevan Church was also spelled "Delavan."

${ }^{18}$ The first three pastors were Rev. John T. Randolph, Rev. James H. Fife and Rev. John Walter George. See: Richard I. McKinney, Keeping the Faith: A History of the First Baptist Church, 1865-1980 (Charlottesville: First Baptist Church, West Main Street, 1981), 44-45.
} 
book."19 No matter how blacks challenged their status, however, they confronted their reality daily.

Advertisements frequently filled the pages of the newspaper. "Nine valuable Negroes at auction. We will sell at our auction rooms on the 6 of March (Court Day) a likely young Negro Man, and a young woman, healthy, and a good house servant, with seven children. They will be sold for cash."20 The Court Days that whites awaited and enjoyed held a different meaning for blacks. Never knowing how the day would end, enslaved black men, women, and children viewed Court Day with dread and trepidation.

Then, in March 1865, General Sheridan's troops swept through town. In a letter to his daughter, one farmer wrote, "the citizens of the town suffered but little, many of them had guards." His estimation of the property that was taken included "corn, meat, flour, horses and negroes." Even though he "could form no correct estimate," he believed "the County has lost many hundred horses, and from 1500 to 2000 negroes.” A reporter from the Lynchburg Daily Virginian claimed, "large numbers of Negroes mounted on stolen horses were seen going off with the Yankees." Self-preservation overrode any concerns of punishment, fear, or loyalty. Likewise, neither did gender constraints deter women's decision to escape slavery. "Women with little children in their arms seemed as eager to be off as the men." 21

\footnotetext{
${ }^{19}$ Charlottesville Chronicle, January 4, 1865.

${ }^{20}$ Charlottesville Chronicle, March 1, 1865.

${ }_{21}$ Margaret W. Fowler Clark, "The Surrender of Charlottesville," MACH, vol. 17 (1958-59); John R. Brown, "The Battle of Rio Hill, Feb. 29, 1864," MACH vol. 22 (1963-64); Mary Rawlings,
} 
Once freedom came, Charlottesville, like countless localities, began the process of adjustment. On the first night of freedom, Georgianna Preston, finally a free woman, recalled, “Ole folks was shoutin' an' singin' songs. Dar's one dey sung purty nigh all night. Don't know who started it, but soon's dey stopped, 'nother one took it up an' made up some mo' verses.

Ain't no mo' blowing' dat fo' day horn.

Will sing, chillun, will sing. Ain't no mo' crackin' dat whip over John, Will sing, chillun, will sing.

Across the south, freedom songs sprung up. Young and old articulated the end of the slave regime. "'Member de fust Sunday of freedom. We was all sittin' roun' restin' an' tryin' to think what freedom meant an' ev'ybody was quiet an' peaceful, all at once ole sister Carrie who was nea' bout a hundred started into talking:"'

Tain't no mo' sellin' today,

Tain't no mo' hirin' today,

Tain't no pullin' off shirts today, Its stomp down freedom today! Stomp it down!

As the feeling of freedom swept through the group, they picked up the tune and carried it out into the air. "Fust thing you know dey done made up music to Sister Carrie's stomp song an' sang an' shouted dat song all de res' de day. Chile, dat was one glorious time!"22

editor, "Sheridan's Raid Through Albemarle, from a letter written by E. R. Watson to his daughter, Mrs. J. Henry Smith," MACH, vol. 14 (1954-1955); Lynchburg, Daily Virginian, March 9, 1865. ${ }^{22}$ Charles L. Perdue, Jr., Thomas E. Barden and Robert K. Phillips, Weevils in the Wheat: Interviews with Virginia Ex-Slaves (Charlottesville: University Press of Virginia, 1976), 58-59, 234-35. For a variety of the freedom songs improvised by the freedpeople. See pages 117,128 , 242, 268. Also, see Gregg D. Kimball's essay, "African, American and Virginian: The Shaping of Black Memory in Antebellum Virginia, 1790-1860" in Where These Memories Grow: History. 
Elite whites expressed their feelings in quite a different way. Public displays of emotion became part of the grieving process. In Richmond, one woman who witnessed the changing of the times remembered the morning of April 3, 1865, when "the Confederate flag that fluttered above the capitol came down and the stars and stripes were run up we covered our faces and cried aloud." Even in their private moments, loss permeated everything. Writing in her diary one month after the end of the war, Sarah Strickler Fife spoke for a segment of those elite whites who now found themselves adjusting to a new order: "I truly believe that African slavery is right. I love it \& all the South loves it. It suits us, \& I do not see how we can do without it." Her deep conviction of white supremacy belied a dependence on an enslaved black population. ${ }^{23}$

When Lt. Colonel Franklin Stratton, agent of the Bureau of Freedmen, Refugees and Abandoned Lands (which came to be known as the Freedmen's Bureau) arrived in Charlottesville in 1865 he reported that a few disorders had

\footnotetext{
Memory and Southern Identity edited by Fitzhugh Brundage (Charlotte: University of North Carolina Press, 1999), 57-77. The appropriation of liberty occurred prior to 1865 , however. During the Civil War, Thomas Wentworth Higginson, a white union commander of a black regiment remembered, "Just as I took and waved the flag, which now for the first time meant anything to these poor people, there suddenly arose, close beside the platform a strong male voice (but rather cracked and elderly), into which two women's voices instantly blended, singing, as if by impulse that could no more be repressed. My country, 'tis of thee, Sweet land of liberty of thee I sing!" See Thomas Wentworth Higginson, Army Life in a Black Regiment (Boston: Fields, Osgood, \& Co., 1870), p. 40.

${ }^{23}$ Sarah Strickler Fife Diary, May 15, 1865, p 56, (University of Virginia, Special Collections.) See also Robert Herndon Fife papers. Anne Freudenberg, editor, "Sheridan's Raid: An Account by Sarah A.G. Strickler," MACH 22 (1964): 57-66. For reactions of Southern women to the war, see Faust, Mothers of Invention: Women of the Slaveholding South in the American Civil War. Particularly see chapter four, "We Must Go to Work, Too", pp. 80-113. Elizabeth Fox-Genovese analyzes problems surrounding the use of the concept of patriarchy in her essay, "Gender, Class, and Power: Some Theoretical Considerations," History Teacher, XV (1982), 255-276. For a discussion of the post-Revolution era see Fox-Genovese's "Cavaliers and Ladies, Bucks and Mammies: Gender Conventions in the Antebellum South" (a paper presented at the Smith College Conference on Conventions of Gender, Feb, 1984) in which she compares Northern and Southern developments.
} 
occurred. He did not specify whether it was the black or white citizens who in "the various localities between here and the Blue Ridge" had been subjected to "small bands of mauraders and robbers." He believed that "there is much need of a military post at this place to preserve order and to protect the citizens."

Perhaps seeing the great mobility of blacks also prompted Stratton to request assistance.

Blacks moved beyond their former boundaries at a dizzying rate. In an effort to determine the extent of their freedom, they traversed both the countryside and the town. Their presence was particularly noted in the fall of 1865 , only months after the war ended. Southall reported, "They flock to town as to a sort of paradise." Finally free to gather en masse, blacks unabashedly acknowledged their new status. When the agents from the Freedmen's Bureau held a meeting in the courthouse yard in October, the editor reported, "On Thursday Charlottesville was black with freedmen. They poured in from all the surrounding country. We suppose fully one thousand or twelve hundred were assembled."24 Eager to learn and adjust to their new status, freedpeople courageously gathered in the courtyard where they had formerly been taken as objects to be sold. ${ }^{25}$

\footnotetext{
${ }^{24}$ Charlottesville, Chronicle, October 7, 1865.

25 In Charlottesville's historic court square is a building called "Number Nothing." A slate sign on the south side of Number "0" with the words "site of slave block" is attached to the building. In James Alexander, Early Charlottesville: Recollections of James Alexander, 1828-1874, edited by Mary Rawlings (Charlottesville, 1942), 19. Mr. Holman W. Walsh recalled that a stone 18 inches high by 15 inches wide by 30 inches was at the curb on the south side of Number " 0 " when he worked there as a young lawyer in 1906. As late as December 1864 Richmond slave traders, Dickinson and Hill, sold male slaves for $\$ 5,300$ each, a boy for $\$ 4,650$ and a girl for $\$ 5225$. See Robert Harold Gudmestad, "The Richmond Slave Market, 1840-1860" M. A. Thesis, University of Richmond, 1993, p. 116 from Lucy Chase Papers. In an interview with 106-year-old Mrs.

Rebecca Fuller McGinness, she recalled a tree stump in front of the Albemarle County Court house. "My grandmother told me that they used to sell slaves on that tree stump." See David A.Maurer, Daily Progress, Charlottesville, February 14, 1999.
} 
Captain Crandon, a Bureau agent, clarified a number of issues in that fall meeting. The freedpeople learned "the lands were not to be divided among the colored people," and that the next year was not going to be "a sort of Jubilee." Consequently they needed to "begin work now and to make contracts at once, and get homes." Crandon further cautioned the freedpeople to "expect modest wages" because "the whites have got no money at present." In addition, Crandon spoke on more personal matters. "As to your families: you should get them together." He urged the newly freedpeople to "stay in the neighborhoods where they found themselves, and not rush to the cities and towns." ${ }^{26}$ Yet, the freedpeople still came into town day after day, exploring emancipation. As freedpeople they now found themselves in a new world.

Capitalizing on the freedpeople's illiteracy and their desire for land, some whites hatched schemes to defraud them. In Albemarle, an illiterate elderly black man "bought" from a white man a piece of land and a shack. With his "purchase" he received a paper, which was supposedly a deed. When the sheriff read the "deed" it stated, "as Moses lifted up the serpent in the wilderness, so have I lifted fifty dollars out of this old nigger's pocket."27 Freedpeople longed to become literate and they pursued education with a fierce determination. "The Lord has sent us books and teachers. We must not hesitate a moment, but go on and learn all we can." They understood education to be a valuable

\footnotetext{
${ }^{26}$ Charlottesville Chronicle, Oct. 7, 1865. Also, see Leon Litwack, Been in the Storm So Long: The Aftermath of Slavery (New York: Vintage Books, 1980). Chapter Six, "The Feel of Freedom: Moving About" (pp. 292-335) discusses the responses of white and federal officials to black mobility across the South.

${ }_{27}$ Workers of the Writers' Program of the Work Projects Administration in the State of Virginia, The Negro in Virginia John F. Blair, Publisher, Winston-Salem, North Carolina, 1994, 243.
} 
commodity. They not only consumed education, they invested in it, securing a wealth that could not be ripped from them. ${ }^{28}$

As early as 1866 superintendents of the Freedmen's Bureau in the subdistricts responded to a request for information. The report illuminates how education was used in the postbellum rural areas to exact a price from recipients. The superintendent in the fourth district (central Virginia), stated:

In agricultural districts the best mode of teaching the freedmen and their children is to have it specified in their [work] contracts that they are to receive so much instruction - deducting for this purpose a small amount of their wages if necessary. ${ }^{29}$

Yet, despite the hands needed to tend the fields, freedpeople continually pursued education. Children especially were encouraged, in fact, expected, to attend school, as well as contribute to the family household chores. Oftentimes, older adults would be in attendance also. Teachers frequently found it necessary to operate schools during the evening hours to accommodate those who thronged to the schoolhouse.

Surrounded by poverty and dissolution, freedpeople and their teachers nonetheless envisioned a better life as they sought to reconstruct the Southern states economically and socially. From Richmond, freedmen teacher Martha $\mathrm{H}$. Chace wrote: "This week, hearing that there was much suffering among the poor on the 'Basin,' which is the principal valley of the city, between the canal and

\footnotetext{
${ }^{28}$ See Jane Guyer's essay for an Africanist perspective on the value of knowledge. Jane Guyer, "Wealth in People as Wealth in Knowledge: Accumulation and Composition in Equatorial Africa" Journal of African History (1995): 91-120. Asa B. Whitfield to Julia A. Shearman, April 17, 1867, American Missionary Association Archives.

${ }^{29}$ Consolidated Report relative to Schools in the Fourth District, Virginia, as required by Circular No. 23, July 18, 1866. Freedmen's Bureau Records, Reel 14, Microcopy 1053.
} 
river, I visited there one morning: found the report true. The cry on the 'Basin' was, as it is all over the city, louder for work than for charity, 'Give me work, for which I can get money to pay my rent and buy bread for my children, and I'll scuffle along without help from Government."30

Massachusetts was the first of the northern states to enact new rules against beggars. In 1866 the Republican-dominated legislature passed an "Act Concerning Vagrants and Vagabonds." Just a month before the new law took effect, Congress had enacted the Civil Rights Act, thereby nullifying the Southern Black Codes, which punished freed slaves for vagrancy and idleness. At the very moment Massachusetts statesmen were engaged in constructing an apparatus of labor compulsions, Republican statesmen in Washington were enshrining the legal supremacy of free labor as a cornerstone of Reconstruction.

When the former head of the Confederate Bureau of War, Robert G. H. Kean, returned to his home, Edgehill, in Albemarle County, he commented on the employment situation in his diary. On many farms blacks had quit en masse. Although the former masters tried to retain the workers, some of the masters simply hired whomever they could find. At $\$ 5$ per month (specie) for a first-class man and \$3 for a first-class woman, freedpeople were hard pressed to remain on familiar ground when they believed they could do better elsewhere. ${ }^{31}$

The contradictory aspects of labor contracts prevailed throughout the southern states after the Civil War. The Freedmen's Bureau carried a double message: an affirmation of the former slaves' right to liberty and a warning that

\footnotetext{
${ }^{30}$ The Freedmen's Record, volume 2, no. 4, April 1866.

31 John Hammond Moore, Albemarle: Jefferson's County, 1727-1976, pp. 219-20.
} 
freedom barred dependence. However, some believed that the bureau was designed to "feed the niggers in idleness." ${ }^{32}$ The head of the bureau, Gen. Oliver Otis Howard, in an effort to dispel the notion that its mission was charitable, declared, "freedom does not mean the right to live without work at other people's expense." Although entitled to choose their employers and to earn wages, former slaves were not free to refuse to labor. The bureau made explicit the double meaning of emancipation: "While the freedmen must and will be protected in their rights, they must be required to meet these first and most essential conditions of a state of freedom, a visible means of support, and fidelity to contracts." 33

Orlando Brown, head of the Freedmen's Bureau in Virginia, declared that blacks must "feel the spur of necessity, if it be needed to make them self reliant, industrious and provident. ${ }^{34}$ On November 7,1866, a teacher in Richmond discerned from the freedpeople surrounding him that "they (the colored people), will be ready, I think, to tax themselves, and intelligently support free schools, long before the "dominant race" are ready to do the same."35

\footnotetext{
${ }^{32}$ Frank Leslie's Illustrated Newspaper carried a cartoon that depicted black men sitting around at the Freedmen's Bureau office playing and listening to the banjo. The caption reads: "The popular idea of the Freedmen's Bureau - plenty to eat and nothing to do." Oct. 6, 1866.

${ }_{33}$ U.S. Congress, House, Orders Issued by the Commissioner and Assistant Commissioners of the Freedmen's Bureau, House Executive Document 70, serial Set 1256, 39 Congress, 1 session, 1865, pp. 139, 155.

${ }^{34}$ William T. Alderson, "The Influence of Military Rule and the Freedmen's Bureau on Reconstruction in Virginia, 1865-1870", unpublished dissertation, Vanderbilt University, 1952.

${ }^{35}$ Freedmen's Record, volume 2, no. 12, December 1866. See James D. Anderson, The Education of Blacks in the South, 1860-1935 (Chapel Hill: The University of North Carolina Press, 1988) who argues that public education in the South came from the beliefs and behavior of former slaves who campaigned for free schooling.
} 


\section{Chapter Two: Envisioning Hope}

We have been compelled, under pain of death, to submit to injuries deeper and darker than the earth ever witnessed in the case of any other people. We have been forced to silence and inaction to look on the infernal spectacle of our sons groaning under the lash; our daughters ravished; our wives violated; and our firesides desolated, while we ourselves have been led to the shambles, and sold like beasts of the field. ${ }^{36}$

Grappling with ideas about freedom after the Civil War must have been a complex and difficult job for those living through the times. The memory of life as a slave left an indelible mark. It shaped the movements of the freedpeople as they entered a new epoch of their lives. Understanding the process of emancipation at the local level has remained elusive. What ideas, values, and traditions ordered the world of the freedpeople? How did the pursuit of literacy shape the daily enactment of freedom?

Fearing the power of literacy, some slaveholders adopted extraordinary efforts to keep blacks from becoming educated. One Virginian tried to ensure that his slave boy remained illiterate. The boy, who delivered mail throughout the neighborhood, was instructed not to look at the addresses on the letters. When the boy arrived with the mail, someone from each household on the route would search through the sack to find the letters belonging to members of that household. ${ }^{37}$ At times the price of illiteracy was devastating. A cowardly letter

\footnotetext{
${ }^{36}$ Leon Litwack, Been in the Storm So Long, pp 518-19. In August 1865 several representatives to the Convention of the Colored People of Virginia expressed the concerns of their constituents in an equally eloquent manner.

${ }^{37}$ Regarding the prevalence of literacy, see Theresa A. Singleton, "The Archaeology of Slave Life," in Before Freedom Came: African American Life in the Antebellum South, ed. Edward D. C.
} 
from a Charlottesville slaveholder to a prominent slavetrader in Richmond held a sadness for all parties involved, especially for Frances, an enslaved young female. "This will be handed to you by my servant Frances," Mr. Crawford wrote, adding that he believed "positively that she is the finest chamber-maid I have ever seen in my life." Seventeen-year-old Frances did not know that she was to be sold. "I could not tell her," Crawford claimed, adding that he owned "all her family, and the leavetaking would be so distressing." Whether he was referring to his own distress or that of the enslaved family is not clear. Yet, despite his obvious regard for hard work and family ties he felt "compelled to sell her to pay for the horses that I have bought, and to build my stable." ${ }^{18}$

As early at 1788, Thomas Jefferson introduced a model for a comprehensive school plan for white males. Continually rejected by the Virginia legislature, other methods became more prevalent. Most Southern states created literacy funds to assist in the education of indigent children. Few options existed for most whites in the middling class who sought an education. Often, laws in some Southern as well as Northern states required that masters instruct both black and white apprentices in literacy as well as job-related skills. Scholars estimate that from 5

Campbell, Jr., with Kym S. Rice (Richmond and Charlottesville: Museum of the Confederacy and University Press of Virginia, 1991), p. 171; Barbara Finkelstein, "Reading, Writing, and Acquisition of Identify in the United States: 1790-1890," in Regulated Children/Liberated Children: Education in Psychohistorical Perspective ed. Barbara Finkelstein (New York: Psychohistory Press, 1979), p. 138, No. 50. For a brief discussion of the efforts of blacks to obtain an education immediately following the war, see Janet Duitsman Cornelius, When I Can Read My Title Clear: Literacy, Slavery, and Religion in the Antebellum South (University of South Carolina Press, 1991), pp. 142-150.

${ }^{38}$ Swann: Printed and Manuscript African Americana, Feb. 15, 2001, public auction sale 1888, number 31, autographed letter from A. M. F. Crawford to Messrs Dickenson \& Hill, slave dealers in Richmond, Virginia. 
percent to 10 percent of the slave population learned to read. ${ }^{39}$ Many

Southerners still relied on voluntary parental, community, and church education initiatives. Characterized by a lack of structure, education in the South languished. Most white Southerners opposed additional taxation while apathy and political conservatism blocked education initiatives.

As the freed black population grew, so, too, did white anxiety about the education of this group. Organizations such as the American Colonization Society (ACS) supported several religious denominations that established schools for free blacks willing to emigrate to Africa. Between 1820 and 1830, nearly 1,400 free blacks received an education through this arrangement under ACS sponsorship. In 1829 the African Education Society of the United States was formed in an effort to support the founding of schools that would "afford persons of colour destined to Africa such an education in Letters, Agriculture and the Mechanical Arts, as might quality them for usefulness and influence in Africa." 40

After 1831, when Nat Turner led a rebellion against slavery, legislators prohibited the teaching of slaves. Yet, defying "anxious patriarchs" who constructed complex systems to maintain white supremacy, blacks learned to

\footnotetext{
${ }^{39}$ William E. Burghardt DuBois estimated that throughout the southern states about 5 percent of the enslaved population had learned to read by 1860 . Eugene Genovese placed the estimate closer to 10 percent.

${ }^{40}$ The full name of the American Colonization Society was the Society for the Colonizing of the Free Blackman of the United States. See Vincent P. Franklin, "Education for Colonization: Attempts to Educate Free Blacks in the United States for Emigration to Africa, 1823-1833," Journal of Negro Education, vol. 43, winter 1974.
} 
invert their enslaved position in society by feigning ignorance. ${ }^{41}$ Defiance against law and custom occurred in many forms. In both Northern and Southern communities, Sunday schools became sanctioned centers for teaching basic literacy skills. John Hartwell Cocke, master of Bremo Plantation, taught some of his slaves to read in the 1820s William Henry Ruffner, who later became Virginia's first superintendent of public instruction, held one of the earliest formal Sunday schools for blacks in Lexington, Virginia, in $1840 . .^{42}$

Both Southern and Northern white women also worked through Sunday schools to educate enslaved people. Letitia Burwell, daughter of a prominent Virginia slaveholder, remembered that from an early age she and her sister operated a "school" to teach the slaves. ${ }^{43}$ Women elsewhere led Sabbath schools and domestic skills classes. Betsey Cowles, a Northern abolitionist, taught a group of ten girls "possessing real black skins" in 1842 at Portsmouth Seminary in Ohio. Compelled to teach those whose skin was colored and who

\footnotetext{
${ }^{41}$ DuBoise, Black Reconstruction: An Essay toward a History of the Part which Black Folk Played in the Attempt to Reconstruct Democracy in America, 1860-1880 (New York: Atheneum), 1972. Eugene D. Genovese, Roll, Jordan, Roll: The World the Slaves Made (Vintage Books, New York), 1972. Richard D. Brown, Knowledge is Power: The Diffusion of Information in Early America, 1700-1865 (Oxford University Press, 1989). James C. Scott, Weapons of the Weak: Everyday Forms of Peasant Resistance (New Haven and London, 1990). Regarding the systems slaveholders designed as early as the Colonial era, see Kathleen M. Brown's Good Wives, Nasty Wenches, and Anxious Patriarchs (Chapel Hill: The University of North Carolina Press, 1996).

${ }^{42}$ Anne Boylan's Sunday School: The Formation of an American Institution, 1790-1880 (New Haven and London: Yale University Press, 1988) is an excellent study of the Sunday school movement. Among the Lexington citizens who felt led to teach black children to read and gain an understanding of the fundamentals of religion in his Sunday school was a Presbyterian deacon, Thomas Jackson, who is better known for his service as a Confederate general, which earned him the name "Stonewall." See Charles Wilson Dabney, Universal Education in the South (Chapel Hill: University of North Carolina Press, 1936).

${ }^{43}$ Letitia Burwell, A Girl's Life in Virginia before the War (Nashville, TN: American Methodist Episcopal Sunday School Union, 1909), pp. 7-22.
} 
"for this crime have been excluded from Sabbath School," Cowles defied society's expectations and proscriptions. ${ }^{44}$

Before the war began, one free black woman, Mary Smith Kelsey Peake, secretly taught both slaves and free blacks in Norfolk to read. When Union officers officially approved her teaching, she became one of the first native-born teachers supported by the American Missionary Association. Peake ushered in a new era in Southern education. ${ }^{45}$

New England also responded before freedom came by sending teachers and supplies to the South. Teachers went first to Port Royal, South Carolina, and Fortress Monroe, Virginia, ready to give "instruction in those areas of civilized life which the negro needs quite as much as book-learning." While supervising the contraband slaves at Fortress Monroe in 1861, Edward L. Pierce noted the people's "widespread desire to learn to read." Teachers arrived determined to inculcate "lessons of industry, of domestic management and thrift, lessons of truth and honesty, lessons which may help their pupils (children and adults) to unlearn the teachings of slavery." ${ }^{46}$ As cultural emissaries, the teachers would remake the South in the image of New England. Educational reformers believed that the process of "New Englandizing" the South could best be done through

\footnotetext{
${ }^{44}$ Julie Roy Jeffrey, The Great Silent Army of Abolitionism (Chapel Hill: The University of North Carolina Press, 1998), p. 129, p. 258, note 93. Letter from Betsy Cowles to Mother, Cowles Papers, Kent State University Library, September 28, 1842.

${ }^{45}$ Mary Smith Kelsey Peake (1823-1862) was born in Norfolk, Virginia, to a free black woman and a white father. Peake was educated in Alexandria, Virginia. At the age of sixteen, she relocated to Norfolk. Between 1847 and 1851, she founded a self-help organization called Daughters of Benevolence. In 1851 she married Thomas Peake, and they had a daughter in 1856. By January 1862 , she was teaching over fifty children in her day school as well as twenty adults in the evenings. One month later she died of tuberculosis.

${ }_{46}$ James D. Anderson, The Education of Blacks in the South, 1860-1935 (The University of North Carolina Press, 1988), p. 5. Freedmen's Record, 1865, vol. 1, no. 1.
} 
education and through women. The history of education began to take on a different garb as New England extended its reach. ${ }^{47}$

Criss-crossing the New England terrain, antebellum benevolent and reform organizations created new beginnings. The New England Freedmen's Aid Society (NEFAS) was one of the many organizations that educated the freedpeople. Founded in 1862, its first president was John S. Andrew, known as the "war governor" from Massachusetts. Among the members of the organization were many abolitionists. ${ }^{48}$ The group published its first edition of the Freemen's Record when the Thirteenth Amendment abolished slavery on January 31,1865 . The purpose of the publication was "to present information on the condition and progress of the Freedmen in the different departments of the South; and to indicate to the New England public the most appropriate channel through which to pour their charities to the Freedmen." 49

Within months after its formation in 1862, NEFAS sent thirty-one teachers to Port Royal, South Carolina, to teach the freedpeople. "The freedmen evince a most earnest desire to be educated," a founding member of NEFAS stated. "Their belief that reading and writing are to bring with them inestimable advantages, seems, in its universality and intensity, like a mysterious instinct." ${ }^{50}$

\footnotetext{
${ }^{47}$ Willie Lee Rose, Rehearsal for Reconstruction (Indianapolis: Bobs-Merrill Company, Inc., 1964).

${ }^{48}$ The Reminiscences of Philena Carkin, chapter one.

${ }^{49}$ The Thirteenth Amendment was ratified by enough states to add it to the Constitution in December 1865. See Freedmen's Record, January 1865, vol. 1, no. 1.

${ }^{50}$ Freedmen's Record, vol. 1, no. 4, April 1865, p. 53. Also see Litwack, pp. 335, 450, 471, 472 $6,484-5,500-1,521,547$ for a discussion of blacks' enthusiasm and their views regarding education.
} 
Many of the officials in the group were members of the Unitarian faith. Unlike the American Missionary Association, which attempted to address the religious aspects of the freedpeople's lives, the officials of NEFAS steered clear of religion. The society sought "absolute freedom from all sectarian connections and aims." Avoiding any potential quagmires, the officials clarified their position: "Our association is not committed to any political theory, nor does it enunciate any mooted theory of the equality of the races." NEFAS focused on literacy and encouraged intellectual and self-development. The society asked the readers of The Freedmen's Record whether it was "humane to leave this people to perish unsuccored? Is it better, is it safer to give them intellectual advantages, which the humblest classes in the free states enjoy, or to leave them to become dangerous classes in their ignorance and barbarism?"151

The officials of NEFAS raised the same specter that Horace Mann raised in his speeches. Although not a member of NEFAS, Mann was known as the "Father of the Common School" in New England. He strongly urged state intervention, or at least state influence, in local affairs. Mann advocated a nonsectarian Protestant Republicanism closer to the teachings of the Unitarian denomination. His concern about the South's effects on the "republican experiment" led him to call for a common school education that emphasized the need for public obedience rather than public participation. He also supported the assimilation of various ethnic groups into American society. The wealthy, who opposed Mann, felt they should not have to pay taxes for public schools when

\footnotetext{
${ }^{51}$ The Freedmen's Record, vol. 1, no. 4, April 1865.
} 
their children were attending private schools. "The aristocrats of Boston began to cry out, where shall we get our servants if the lower class is to be educated." 52 Mann countered by saying that without education the masses would become an ignorant rabble. He presented education as a stabilizing process. He also hoped to overcome economic divisions in Massachusetts. ${ }^{53}$

NEFAS also attempted to integrate the freedpeople into society. The society's officials worked with local officials as early as possible to implement a graded school system. In a statement about their mission, the officials asserted: "We shall never be willing to pause in our labors, until the earliest and dearest institution of New England, the free school, shall be established throughout the land." 54

By 1830 New England reformers had begun a system of common-school education on the state and local levels as envisioned by Jefferson. ${ }^{55}$ Reformers believed that a school system based on uniformity throughout the land would facilitate a national identity. They also believed that a nation composed of educated men would foster a civic-minded populace and a better republic. To that end they called for standards that encompassed teacher training, books,

\footnotetext{
${ }^{52}$ Boston Public School Records, Letter to Mrs. Ednah Dow Littlehale Chase, n.d.

53 Jonathan Messerli, Horace Mann: A Biography (New York: Knopf, 1972); Susan-Mary C. Grant, "Representative Mann: Horace Mann, the Republican Experiment and the South." ${ }^{54}$ Freedmen's Record, vol. 1, no. 4, April 1865.

55 By 1855 common school systems existed in ten counties and four cities throughout Virginia. William A. Maddox, The Free School Idea in Virginia Before the Civil War (Teachers College, Columbia University, New York, 1918).
} 
curriculum development and grading. Boston and New York became the model upon which all other school systems followed. ${ }^{56}$

Between 1830 and 1880 teaching had become women's work. When women first entered the teaching profession, a new set of beliefs glorified women's place in the home. ${ }^{57}$ School committees sought teachers who would fit this ideal woman: pious, pure, domestic and submissive. Many of the teachers who came to the South embodied two images of the mid-nineteenth century woman. One image stressed piety, purity, domesticity, and submissiveness: the components of what has been called "the cult of true womanhood." The cultural model of femininity during the nineteenth century placed demands on women to exhibit a genteel, ladylike demeanor with a self-sacrificing character. However, venturing into unknown territory, stamina, and self-sufficiency, combined with an adventuresome nature that had been well grounded in gentility, assured success in the mission field. This image emphasized physical fitness, higher education, and the ability to be an independent thinker. This was the ideal of real womanhood..$^{58}$

School committees used this ideal woman to redefine teaching as a feminine vocation. Educational reformers also believed that female teachers would be

\footnotetext{
${ }^{56}$ Carl F. Kaestle, Evolution of an Urban School System, pp. 159-84. Stanley K. Schultz, The Culture Factory, pp. 3-131. Michael B. Katz, Class, Bureaucracy and Schools, pp. 56-104. David B. Tyack, The One Best System, pp. 28-77. Jonathan Messerli, Horace Mann, p. 442. The Boston School Committee Records at the Boston Public Library provides insight into the formation and evolution of the common school system in Massachusetts, particularly Boston. ${ }^{57}$ Ann Douglas, The Feminization of American Culture (New York: Alfred A. Knopf, 1977).

${ }^{58}$ See Barbara Welter, "The Cult of True Womanhood, 1820-1860," in American Quarterly, 18 (Summer, 1966): 151-74. Frances B. Cogan, All-American Girl: The ldeal of Real Womanhood in Mid-Nineteenth Century America (Athens, 1989). Lori D. Ginzberg, Women and the Work of Benevolence: Morality, Politics and Class in 19th Century United States (New Haven, 1990).
} 
more amenable to changes within schools. Those changes included a longer school year, graded classes, and increased supervision. ${ }^{59}$ The number of $^{2}$ teachers increased in Massachusetts between 1834 and 1860 as more women became educated and sought teaching training. ${ }^{60}$ As the profession became more feminized, the number of male teachers declined. Still, the teaching force was never more than two percent of all white women between the ages of 15 to 60 years old. ${ }^{61}$

By 1865 petitions to increase the salaries of female teachers flooded the offices of the Boston School Committee. Citizens and taxpayers claimed that the salaries of the teachers were so low that they "were barely sufficient to enable them to maintain the social position to which their education and abilities entitle them." Citing an increase in living expenses "from fifty to one hundred percent during the past four years," the petitioners believed the high "reputation of our teachers and the mark of our schools" could not be maintained without fair compensation. Another petition from the assistants and primary teachers of the Boston school system stated that "board in 180 could be obtained for $\$ 3.00$ per week" but by 1865 board was "unattainable for less than $\$ 5.50$ and $\$ 6.00$ per

\footnotetext{
${ }^{59}$ In addition, women's lower wages allowed local school committees to implement these changes without raising taxes.

${ }^{60}$ In $1834,56.3$ percent of the teaching force was female. By 1860 , the percentage has risen to 77.8 percent.

${ }_{61}$ The literature on the feminization of the Protestant churches in the antebellum North includes Nancy F. Cott, "Young Women in the Second Great Awakening in New England," Feminist Studies 3 (1975): 15-29; Cott, Bonds of Womanhood, 126-59; Susan Juster, Disorderly Women: Sexual Politics and Evangelicalism in Revolutionary New England (Ithaca: Cornell University Press, 1994); Barbara Welter, "The Feminization of American Religion, 1800-1860" in Mary Hartman and Lois Banner, eds., Clio's Consciousness Raised: New Perspectives on the History of Women (New York: Harper Torchbooks, 1973): 137-57; Ann Douglas, The Feminization of American Culture (New York: Alfred A. Knopf, 1977).
} 
week, and this exclusive of fire and lights." The petitioners also stated "the prices of all kinds of fuel are double those of 1860." In addition, they claimed, not only had clothing costs increased, "but the very thread of silk with which it is sewed is of proportionate value." In the event of illness, "a teacher is required to pay to a substitute $\$ 1.25$ per day. An absence of one week involves a cost of $\$ 7.50$ with an additional expense for medical attendance and medicines" and on a salary of $\$ 10.50$ a week for those teachers who have served for at least four years, teachers were often hard pressed to live comfortably. Furthermore, "the Head Assistant of the Normal School," a position usually held by males, "received $\$ 600$ which salary has been increased 50 per cent." Another position, the Head Assistant of Grammar Schools "received $\$ 500$ which has been increased by 40 per cent." Yet, "the salaries of the assistant and primary teachers which were $\$ 450$ have been increased only 33 and 1/3 per cent." Acknowledging their assertiveness, primary teachers felt compelled to advocate for better wages "although delicacy counsels silent grief, a sentiment which we call justice leads us to imitate the renowned vocalist who loudly proclaimed his 'silent sorrow' through the streets of the city." In willfully stepping out of their place as long-suffering professional devotees, teachers and their advocates enacted freedom through the traditional channel of petitioning." ${ }^{62}$

Throughout the northeast, an army of supporters, many of them active in the abolitionist movement, readied themselves to educate the freedpeople. White women, in particular, challenged racial and gender norms by working among and

$\overline{62}$ Boston School Committee Records, Boston Public Library, December 1865. 
for African Americans. ${ }^{63}$ Between 1862 and 1865, NEFAS employed two hundred and twenty teachers. "The minimum salary of teachers of both sexes" was "twenty dollars per month and board, or thirty-five dollars per month without board, for the school year of ten months." Salaries were paid by the month and transportation was always paid, unless the teacher returned without orders. ${ }^{64}$ In 1864,43 teachers had been sent out and 28 were supported by auxiliary societies. In 1865, the number of teachers working under the auspices of NEFAS was 54, nine men and 45 women. Among the 54 teachers, several denominations were represented, including Unitarian, Quaker, Baptist, Methodist, and Orthodox Congregational Communions. In soliciting teachers, NEFAS "expects its teachers to be religious in character and influence," but they made clear they would impose "no sectarian tests. Its teachers, like its officers, represent almost every shade of religious opinions." 65

One of the main prerequisites NEFAS officials stressed for teachers was health "to insure energy, cheerfulness, and courage, for the work." Realizing the tremendous reserves teachers would need in this endeavor, the officials understood that "no person of the right disposition can be among the freedmen without feeling a constant temptation to overwork." Although they did not insist upon extra work, the officials also knew that "evening schools, sewing schools, Sabbath schools, are often added to the regular school-duties." Recalling earlier

\footnotetext{
${ }^{63}$ Julie Roy Jeffrey, The Great Silent Army of Abolitionism (Chapel Hill: University of North Carolina Press, 1998).

${ }_{64}^{64}$ Freedmen's Record, vol. 2, no. 6, June 1866, p. 108.

65 Freedmen's Record, vol. 1, no. 4, April 1865, pp. 49-50. See also Jacqueline Jones, Soldiers of Light and Love: Northern Teachers and Georgia Blacks, 1865-1873 (Athens: The University of Georgia Press, 1992) for an understanding of the American Missionary Association's ideology.
} 
letters from teachers, the officials emphasized the conditions teachers would often find. "The people are naked, hungry, sick: the teacher often aids in distributing the supplies, and caring for the bodily wants. Then, the people begin to trust in her, and come to her for advice and comfort and sympathy. This taxes the mind and heart as well as the body; and there must be a good stock of vitality to meet such a demand." 66 NEFAS officials determined that "one month, or six weeks of vacation is considered necessary for each teacher." The officials strictly adhered to this stipulation, claiming the Southern heat was too much for the teachers to endure.

In addition, teachers should have "earnestness of purpose. No mere youthful enthusiasm, love of adventure, or desire of change, will sustain a teacher through for labors and hardships of her work." Calling upon the need to step outside herself and envelop all people, prospectiverteachers were also admonished to "see in the freedmen the representatives of humanity." Appealing to the patriotic spirit, teachers "should feel also the importance of the work in relation to our country: that she is forming the people who are to influence very largely its future, for good or evil." Besides these attributes, officials in freedmen's aid organizations looked for women "with good moral character, a good New England education, and experience." Proud of the New England school system, and, in particular, the Boston school system, officials hoped to replicate "this system, with such modifications as new circumstances may require." When a gentleman told one of the officials, "you have taken our best teacher(s)," the

${ }^{66}$ Freedmen's Record, vol. 1, no. 5, May 1865. 
official replied "that is precisely what we mean to do: the freedmen need the best, already trained and experienced. New England can raise up new ones to fill their places for herself." ${ }^{67}$

\section{The tradition of benevolent work, prevalent among New England women,} changed geographic domain and took on a patriotic role. ${ }^{68}$ Anna Gardner was one of the first teachers sponsored by NEFAS. She was a native of Nantucket, Massachusetts, and her family had been involved in abolitionist activity for a number of years. Prior to her 1865 arrival in Charlottesville, Gardner had taught in New Bern, North Carolina. By the spring of 1866 The Freedmen's Record reported that 180 teachers had been sent to the South. ${ }^{69}$

Letters from teachers and students, as well as annual reports, solicitations, and editorials, filled the pages of the organization's newspaper, The Freedmen's

\footnotetext{
${ }^{67}$ Freedmen's Record, vol. 1, no. 5, May 1865. NEFAS officials also differentiated among the type of teachers they needed. "Where the work includes visiting the people at their homes, instructing them in housekeeping or branches of labor, or where the refugees flock in, sick and travel-worn, and needing immediate care - we need a different class of women. Those who have had the charge of large households, matrons of benevolent institutions - one who had gained a medical education, we have found work exactly fitted for them to do. Our young friends - the bright, enthusiastic girls whose hearts are full of zeal for the good cause ... we do not think it right to send them." Equally difficult, but necessary to refuse, the officials thought, were older women. "It is even harder to refuse those whom we fear are too old to go - those who, having worked faithfully for many years, feel as if they had yet some strength and life to give to the freedmen. If they occupy the places which more young and vigorous persons might have, they are standing in the way of the cause they love, instead of helping it forward."

${ }^{68}$ The American Missionary Association (AMA), the largest evangelical freedmen's aid society, was formed in 1842. Allied with the evangelical wing of American Protestantism, the organization proposed to purify the entire nation. See Jacqueline Jones, Soldiers of Light and Love: Northern Teachers and Georgia Blacks, 1865-1873 (Athens: University of Georgia Press, 1980), pp. 1448. Jones provides an overview of the different organizations that formed prior to and during the Civil War; however, the focus of her study is on AMA teachers in Georgia.

${ }^{69}$ Initially, NEFAS teachers were sent to South Carolina and Florida. However, by 1864, the officials had decided to consolidate the majority of their teachers into a few states in the upper South. The New York Society maintained 206 teachers by the spring of 1866 . The Philadelphia Society supported 60 teachers; Baltimore supported 50 teachers. The new societies of Cincinnati and Chicago financed 130 teachers while the American Missionary Association supported 327 teachers. See Willie Lee Rose, Rehearsal for Reconstruction (Indianapolis: Bobs-Merrill Company Inc., 1964) p. 333.
} 
Record. The conditions in which the teachers found themselves attested to the destitution of the freedpeople. From New Bern, Anna Gardner wrote, "Many are unable to attend school, for lack of the rags in which scores of those who come are clothed." 70

When Anna Gardner arrived in Charlottesville in the spring of 1865 , the white population did not welcome her with open arms. Initially, Gardner boarded in the Musgrove's family home. R. A. Musgrove, a white man, operated a dry goods store located on West Main Street. He had also established a tuition school for blacks. Thirty-two black students attended this school, where Musgrove taught reading, writing, and arithmetic. Gardner learned from the freedpeople that Musgrove's daughter was "ashamed to go into the street while her father was teaching niggers." Musgrove also augmented his family's income by taking in Gardner as a boarder, and, as a result, his daughter "threatened to leave his house." Consequently, Gardner moved out. But apparently circumstances became so dire that Musgrove was forced to open his home to other boarders. Musgrove's daughter "must have undergone quite a conversion, for they have taken in a number of Yankee men - officers," Gardner dryly noted. ${ }^{71}$

Located on "the south side of University Street, extending from the corner near the Dry Bridge to the Junction Depot," the three-story Delavan building had initially been a hotel built by Gen. John Hartwell Cocke. It then became a classical school, and then the barracks and finally a hospital for Confederate

\footnotetext{
${ }^{70}$ For the literate world of Anna Gardner, see her book, Harvest Gleanings (New York: 1881), Alderman Library, Special Collections, University of Virginia. Freedmen's Record, vol. 1, no. 1.

${ }^{71}$ NEFAS, Daily Records, Nov. 4, 1865; Freedmen's Record vol. 2, no. 1, Jan. 1866, p. 4.
} 
soldiers before it landed in the hands of the federal government. Large pillars flanked the front of the building. The Delevan was also known as the "Mudwall" because it was "covered with stucco stained with the tawny hue of Albemarle Clay. $^{72}$

One of Gardner's first letters from Charlottesville described her interactions with the freedpeople. "The colored people have been exceedingly kind and attentive to me. They were very shy at first, but as soon as convinced that I was really a friend they flocked from every quarter to render assistance." Opening their hearts and sharing their meager furnishings from their homes, they came "bringing chairs, tables, curtains, \&c." Yet for all their eagerness to help, Gardner noted a reticence on the former slaves' part as "they felt their way very cautiously, before giving me their confidence. ${ }^{73}$ The freedpeople showed a wariness born of years of servitude and submission. Fear had kept them shackled to a circumscribed world, both physically and psychically. Gardner recalled the fears of one woman who confided, "I wanted to come to you at once, but did not dare, we have been so afraid of white people." ${ }^{14}$ Nonetheless, they stepped out of their limited place to experiment with their newfound freedom.

As the freedpeople assumed new roles, Gardner began to move beyond her duties as a teacher. Surrounded by poverty, Gardner found herself meeting the basic needs of the freedpeople and sought to raise money for the purpose. She

\footnotetext{
${ }^{72}$ Mary Rawlings, ed., Early Charlottesville, Recollections of James Alexander, 1828-1874 (Charlottesville: Albemarle County Historical Society, 1942): pp. 102-3. Lay, The Architecture of Jefferson County, pp. 225, 228, 239-40.

${ }^{73}$ NEFAS, Daily Records, 1865, October 23, 1865; Freedmen's Record, vol. 1, no. 12, 1865, Charlottesville Chronicle, November 28, 1865

${ }^{14}$ Freedmen's Record, vol. 1, no. 12, December 1865.
} 
invited the readers of The Freedmen's Record to "look in upon the empty larders of these poor sufferers." J. C. Southall, editor of the Charlottesville Chronicle, also noted their dire straits. Often without food and many times living in cramped quarters, the freedmen "swarm in all the cellars and holes in the town, and in all the shanties on our suburbs," Southall said. Upon receiving contributions toward her efforts, Gardner wrote back to inform the contributors of how the money was used. "Thanks for the dollar received in your letter. I do not find any better way of disbursing small sums, than by purchasing five cent loaves of bread, and sending them by my waiting woman to the hungry people (colored); who are to be found in the barracks all around me."75

By making "the acquaintance of the colored people" before opening her school, Gardner "found one woman who was a slave up to the time of Lee's surrender, engaged in teaching a 'pay school." Isabella Gibbons was the mother of several children by William Gibbons, who was also enslaved. When NEFAS officials wrote their annual report, they referred to Isabella Gibbons as "the mother of several children, whom she must aid in supporting." The officials saw in Gibbons their reason for being. "She wishes to perfect her own education and become a teacher of her people." Conveniently overlooking the fact that Gibbons was married to a literate minister, Reverend William Gibbons, the officials cast Isabella in the role of a dependent, albeit, intelligent woman, in need of their support. In addition, she was worthy of their support because she had

${ }^{75}$ Freedmen's Record, vol. 2, no. 3, March 1866. In Early Charlottesville, James Alexander stated that "long wooden houses" on either side of the Delevan were erected for the sick at the outset of the Civil War, p. 108. 
contributed to the Union cause. "She is doubly precious to our hearts, as the devoted nurse of one of the noblest and best-beloved of our young officers, who died a prisoner in rebel hands." ${ }^{76}$ Thus cast as the loyal and worthy servant, deserving of all the benefits the Society could give, the officials claimed Isabella Gibbons as their protégée. Selected as a role model, Gibbons became part of the vanguard of the reconstructed South.

When a white woman said, "Now that the Northern lady has come to teach 'free school,' you will lose all your scholars," Gibbons bravely informed the lady "I shall not expect anybody to send children to me, when I send mine to the Northern lady." Gardner "devoted considerable time" training Gibbons "to be my assistant teacher." Gardner saw positive attributes in Gibbons, and she believed Gibbons possessed "one excellent qualification for a teacher, - a very distinct articulation in speaking and reading; almost entirely free from negro dialect." Gardner was so taken by Gibbons' ability that she doubted "whether a dozen persons could be found in Charlottesville, who can excel her in that respect." So impressed was Gardner with her abilities that she sought financial funding for Gibbons. "I would like to make a proposition to you to pay her something now, for assisting me, while she remains a scholar, in anticipation of being regularly employed as soon as she can qualify herself for that purpose. ${ }^{77}$ Before the end of the year, the society wrote back to "employ the colored woman, Mrs. Isabella Gibbons (sic), and we will pay her $\$ 10$ per month. ${ }^{178}$

\footnotetext{
${ }^{76}$ Freedmen's Record, vol. 2, no. 5, May 1866.

77- Freedmen's Record, vol. 2, no. 1, January 1866, pp. 4-5.

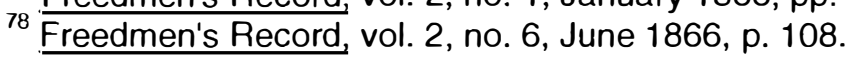


Gardner noted that Isabella Gibbons "reads well and writes." While still a slave, she risked her well-being as the "reader general all through the war, to the colored people, both free and slave." Transcending her role of mother and wife, Gibbons used her literacy skills to inform the larger community. Her literacy also helped the illiterate learn about the wider world in which they lived. Gibbons "has read to one colored man who has paid for a paper for the past four years, though he cannot read a word himself. He is exceedingly well-informed with regard to the events of the war, and the relation of the colored people to the government." ${ }^{79}$

Perhaps the black man knew President Lincoln had believed that with education blacks should qualify for citizenship, at least on a restricted basis. ${ }^{80}$ He might also have known that Frederick Douglass had called for Negro suffrage as an essential part of postwar Reconstruction. ${ }^{81}$ The National Anti-Slavery Standard proclaimed that "this is the negro's hour." The ballot for Negro men, the writer continued, was necessary in order to assure that the freedom achieved in the Thirteenth Amendment would not become a mockery. ${ }^{82}$ However, knowledge of these things did not give him or other black men the right to vote.

\footnotetext{
${ }^{79}$ Freedmen's Record, vol. 2, no. 1, January 1866.

${ }^{80}$ In 1864 Lincoln wrote to Gov. George M. Hahn of Louisiana asking "whether some of the colored people may not be let in [to the elective franchise] as, for instance, the very intelligent, and especially those who have fought gallantly in our ranks. The new legislature met in the fall of 1864 and failed to extend the franchise to any Louisiana blacks, despite their intellectual or economic standing.

${ }^{81}$ The Liberator. February 10, 1865.

82 National Anti-Slavery Standard, December 30, 1865. For the role played by women's rights leaders, particularly Elizabeth Candy Stanton and Susan B. Anthony, in achieving the Thirteenth Amendment, see James M. McPherson, The Struggle for Equality: Abolitionists and the Negro in the Civil War and Reconstruction (Princeton, N.J., 1964), pp. 125-26.
} 
"Such are the men that are deprived of voting, because, perforce, they have not been allowed to learn to read," Gardner fumed. ${ }^{83}$

Gardner, aware of political maneuverings from the newspapers, was probably referring to proposed restrictions on black mobility. By February 19, 1866, Southern state legislatures enacted the "Black Codes." These codes varied in hardness, but essentially they were a body of vagrancy and apprenticeship laws. In an effort to protect blacks, Congress attempted to enlarge the scope of the Freedmen's Bureau as a temporary bureau to care for the freedpeople as well as the abandoned lands of the South. In addition, Congress sought to empower the bureau to try by military commission persons accused of depriving freedmen of civil rights. Because eleven Southern states were not represented, Johnson used this fact to veto the bill, arguing that Congress had no power to legislate. He also claimed that military trials violated the Fifth Amendment. ${ }^{84}$

By April 9, 1866, the Civil Rights Act bestowed citizenship upon blacks and granted the same civil rights to all persons born in the United States (except Native Americans). Congress overrode the veto of President Johnson, who had condemned the measure as an unwarranted invasion of states' rights. The act enumerated various rights to inherit, purchase, lease, and convey real and personal property, including the right to make and enforce contracts, to sue, and give evidence.

\footnotetext{
${ }_{84}^{83}$ Freedmen's Record, vol. 2, no. 1, January 1866, pp. 4-5.

${ }^{84}$ The Black Codes were initially enacted in Mississippi on November 24, 1865, where they were particularly harsh, as they were in Louisiana. Georgia's Black Codes were relatively lenient.
} 
On its heels followed the Fourteenth Amendment. The amendment came about so quickly in large measure because of the widespread doubt as to the constitutionality of the Civil Rights Act. The amendment for the first time defined national citizenship to include blacks and threw the protection of the federal government around rights that might be invaded by the states. ${ }^{85}$

Because so many freedpeople sought an education, Gardner found it necessary to create a selection system. Children as well as adults were grouped according to their abilities. Before the process was too long under way, she professed herself "agreeably surprised at the ease and alacrity with which the scholars fell into line of classification. About one third could read in the Second Reader, one third could spell words of two or three letters, and the remainder were ignorant of the alphabet."

In addition to sending teachers, New England supplied books as well. NEFAS officials noted the "ever increasing calls for schoolbooks of many kinds" from freedmen teachers. As Boston school officials selected new textbooks, Mrs. Hannah E. Stevenson, secretary of the committee on teachers for NEFAS, asked the school officials to donate "the discarded books for the benefit of the freedpeople." She had noted "the changes occasionally made in books used in our Common Schools," and believed that "the discarded ones could be given to this Committee for immediate use in the Schools of its teachers, now employed in the instruction of Freed People from Washington to Jacksonville inclusive."

\footnotetext{
${ }^{85}$ See John Hope Franklin's Reconstruction after the Civil War (Chicago: The University of Chicago Press, 1994, 2d ed.). On the Civil Rights Act of 1866, see pp. 60-61, 66, 222. On the Fourteenth Amendment, see pp. 61-8, 80-82, 110, 168, 196, 222.
} 
When her letter was read at the quarterly meeting of the Boston School

Committee, the members agreed that "such books now no longer used in the

Primary Schools belonging to the city be placed at the disposal of the New

England Freedmen's Aid Society." 86 The textbooks included McGuffey's Reader

(as well as McGuffey's_Eclectic First Reader), Webbs' Normal Reader, and The

National First through Fifth Reader (sometimes referred to as Parker and

Watson). A variety of books were used for other subjects. They included

Sanders Spelling Book as well as the National Elementary Speller. In 1866,

Arnold Henry Guyot of New York published Physical Geography and Common

School Geography. Augustus Mitchell of Philadelphia published A System of

Modern Geography as well as Mitchell's Primary Geography. Lydia Maria Child

published The Freedmen's Book, which was written specifically for Southern

blacks. It contained biographical sketches of heroes of black liberation that were meant to inspire pride and self-determination in the children. ${ }^{87}$

Gardner did her best to adhere to the small class sizes (of 55 to 57 ), which had become the Boston standard. She found the goal difficult to accomplish as old and young "have thronged to my room, leaving me scarcely an hour by myself." The two thirds who had some knowledge were part of a group who had received exposure to letters in one way or another. Basing her classification on

\footnotetext{
${ }^{86}$ Boston School Committee Records, January 31, 1865, March 14, 1865.

${ }_{87}$ McGuffey's Reader was published in Cincinnati during the 1840s and '50s. TheMcGuffey's Eclectic First Reader was particularly popular. Webb's Normal Reader, published by Shelton \& Co. in New York during the 1850s and '60s, was another widely used textbook. The National First Through Fifth Reader was the most widely used series. It was published by A. S. Barnes \& Co. in New York during the last half of the 1860s. A. S. Barnes also published The National Elementary Speller in 1866. Sanders' Spelling Book was published in the $1840 \mathrm{~s}$, '50s and '60s by Charles W. Sanders.
} 
the existing structure in the Boston school system, Gardner limited the enrollment. $^{88}$

Undeterred, students continued to seek instruction despite the overcrowded conditions in the schoolroom. Gardner increased her working hours to help those who could not attend school during the day because of work obligations. "I have also kept a night school for adults in my room." Soon after spending time with the students she commented on the extent of the freedpeople's desire and determination to acquire an education in comparison to Northern white students: "They often seek knowledge with more avidity, and acquire it more readily than those learning the same branches at the North." Gardner was able to report toward the end of 1865 that she had "a pleasant school of fifty scholars." 89

${ }^{88}$ Education reforms in the Boston school system had changed the size of classes from sixty to fifty-six. The grammar school was composed of children between the ages of eight and sixteen in classes no larger than fifty-six. See minutes of the Boston School Committee, Boston Public Library.

${ }^{89}$ Freedmen's Record, vol. 2, no. 1, January 1866, p. 4. 


\section{Chapter Three "The Enemy's Territory"}

One year of peace had not effaced the outward scars of war.

Remnants of old uniforms, old canteens, and the bleaching bones of horses were scattered all about, while here and there stockades and other defensive works still remained. ${ }^{90}$

Philena Carkin

Charlottesville, Virginia, 1866

On February 16, 1866, Philena Carkin had come into the New England

Freedmen's Aid Society offices in Boston. By February 28, she had received her commission to teach and made her way to Charlottesville, Virginia. Not much is known of Philena Carkin prior to or following her stay in Charlottesville. She was the sixth of Josiah and Jemima Carkin's nine children. The family lived in Tyngsborough Township in Middlesex County, Massachusetts, about sixty miles northwest of Boston near Lowell. In 1855, Josiah Carkin listed himself as a farmer; by 1860 , however, the 57 -year-old man listed himself as a stone-cutter with real estate valued at $\$ 400$ and personal property of $\$ 25$. Philena's younger brother, Harrison, fought in the Civil War, while one of their younger sisters, Angelina, became a teacher. ${ }^{91}$

The majority of mid-nineteenth century New England teachers were native-

${ }^{90}$ Philena Carkin, "The Reminiscences of My Life and Work among the Freedmen of Charlottesville, Virginia, from March 11866 to July 1 1875", University of Virginia Archives, Alderman Library, Special Collections. Hereafter cited as Carkin, Reminiscences.

${ }^{91}$ The following are birth dates of the offspring of Josiah and Jemima (Burrows) Carkin: Henry (1827), Silas (1829), Elvira (1832), Reuben (1834), Irena (1836), Philena (1838), Harrison (1840), Angelina (1841), and Martha Maria (1844). Vital Records of Tyngsborough, Massachusetts (Salem, Massachusetts, 1913), 13, \#96; 1855 and 1865 Massachusetts State Censuses for Townsend and Tyngsborough, compiled by Ann S. Lainhart (Boston, 1989), 109-8; Eighth Census of the United States, 1860, Roll 506, (Massachusetts, Middlesex County, 48). During the Civil War Harrison Carkin fought as a volunteer and as a private in Company C, $14^{\text {th }}$ Regiment. Elias Nason, A History of the Town of Dunstable, Massachusetts (Boston, 1877), 192. 
born Protestant Americans. Most were of British and Northern Irish descent.

Because of limited economic opportunities and career choices, females more often went directly from their parents' homes to normal schools where they received training to become teachers. A large number came from farms. The owner-manager and artisan classes combined accounted for 40 percent of the students. Female teachers in Massachusetts always earned about 60percent less than their male counterparts. In addition to pursuing their intellectual interests, economic independence was another motive to teach. As late as 1867, when one young woman, Nellie Gay, searched for a teaching position all she wanted was "at least two dollars a week."

Adjusting to life in the South proved a constant challenge to the teachers from New England. Most likely Carkin was a member of the Congregationalist or Universalist faith. Both these denominations emphasized education. Carkin found herself competing with the religious habits of her students. "One of the greatest difficulties we had to contend with in our work, was the occasional spell of madness which would attack the chief part of the community of colored people, called a religious revival." Carkin believed that "when the frenzy was at

\footnotetext{
${ }^{92}$ Richard M. Bernard and Maris Avinovskis, "The Female School Teacher in Ante-Bellum Massachusetts," in Journal of Social History 10 (1977) pp 332-45. Thanks to Martin and Jane Davis. In addition, women's lower wages allowed local school committees to implement changes without raising taxes. See also Anne Douglass, The Feminization of America regarding cultural changes in the education field. For a study of literacy and females in New England between 1750 and 1820 see Kathryn Kish Sklar, "The Schooling of Girls and Changing Community Values in Massachusetts Towns, 1750-1820" in History of Education Quarterly, vol. 33, no. 4 (Winter 1993) pp 511-41. Jo Anne Preston, "Female Aspiration and Male Ideology" in Current Issues in Women's History, 1989, pp. 171-182.
} 
its height, all sense of responsibility in other matters became second to the one idea of saving souls." 93

Where religion was concerned, she believed the freedpeople lost their ability to reason. The religious revivals tested her patience. "Meetings would be held every night far into the small hours of the morning where, not only men and women, but even little children, many not more than five or six years old, would be exhorted and prayed for, until frightened and excited, they would be led trembling and crying to the 'mourners bench'." Acknowledging the presence of children exemplifies the acceptance among freedparents to include their children in matters deemed important. Carkin attended a revival where she watched as "they would seem to fall in fits, and roll upon the floor, groaning and praying; the more ignorant the subject, the greater and more wonderful were the manifestations of a new birth."94

Casting them as "victims of the prevailing mania," Carkin noted that her students "would lose all interest in their studies, and possibly give up school entirely for a time, until the heat of the spiritual contest was over," after which time they "would return to us, anxious to be installed in their old positions as pupils." Carkin viewed their emotional outbursts as signs of a gullible people, easily led by that which they could not understand. "Before many weeks had

\footnotetext{
${ }^{93}$ Alderman Library, University of Virginia, The Reminiscences of Philena Carkin. ${ }^{94}$ On religious conversions, specifically regarding enslaved blacks, see Lawrence $W$. Levine, Black Culture and Black Consciousness: Afro-American Folk Thought From Slavery to Freedom (Oxford University Press, 1977), pp. 36-37, 39, 42, 60-61, 453 n. 31. On revivalism see pages $18-19,21-22,34,38-39,61,232,451$.
} 
passed, the bountiful harvest of converts would be much reduced by many backsliders."

Of Charlottesville, Carkin noted "The people of the place were professedly religious and there were a goodly number of churches of the various Orthodox denominations - Presbyterians, Methodists, Baptists, Carmelites, etc." Sunday sales were prohibited. Those found guilty of selling "goods, wares, merchandise, spirits, or wine" were fined $\$ 10$. This ban did not apply to tavern keepers or to other citizens if they felt an emergency existed at the time of the transaction. Another Sabbath regulation stated that goods brought to town for sale on that day could be confiscated, one half to go to the informer and one half to the town itself. $^{95}$

Carkin considered at least one among the freedpeople, however, as a "very honest and intelligent young woman." Margaret Terry shared her conversion experience with Carkin who believed that "this girl - Margaret - was of a naturally curious turn of mind, and anxious to attain the highest spiritual good through any source that offered opportunity." Margaret attempted to "make her companions understand her feelings" but to no avail as "their minds so full of their own crude ideas of what religion meant they failed utterly to comprehend her views." Carkin assumed that Margaret "always felt there was a mistake, because her quiet desire for spiritual good seemed so different from the wonderful experiences she had heard related by others." Aware that the "great mass of the colored people held very unique views as to what constituted

\footnotetext{
${ }^{95}$ Woods, Albemarle, p. 162.
} 
religion," Carkin attempted to explain their religious beliefs as best she could. "It seemed to be a subtle something which elevated its subject to the dignity of a 'child of God,' without in the least affecting his moral attitude towards his fellow men." Carkin also noted "certain acts in life which were considered sinful if committed by a member of the church, although they could bring no harm to the unconverted as they were already as deep as possible under the 'wrath of God,' and no act of theirs could possibly make them more vile than they were by nature." Indeed, even "games were forbidden to church members," in addition to "the singing of secular song." 96

Carkin concluded "the more intelligence became disseminated" among her students the more successful would be her work. In order to be successful, however, she and other teachers had to overcome the strong pull of religion on the freedpeople. "The whole idea of a religious revival among the Freedmen at the time of our work there could be summed up in the phrase 'Spiritual Intoxication."”97

A major part of the revivals as well as the regular Sunday services was the singing, which Carkin described as "natural to the negro as to the birds and all their religious exercises were varied and enlivened by Gospel Hymns, and the old plantation melodies." Uncertain of their origins, Carkin conceded that the

\footnotetext{
${ }^{96}$ Carkin, Reminiscences.

${ }^{97}$ Many if not most of the members of the New England Freedmen's Aid Society belonged to the Unitarian faith. For an in-depth examination see: Lawrence Buell, Literary Transcendentalism: Style and Vision in the American Renaissance (Ithaca: Cornell University Press, 1973); William Ellery Channing, William Ellery Channing: Selected Writings, ed. David Robinson (New York: Paulist Press, 1985); Perry Miller, "From Edwards to Emerson," in Errand into the Wilderness (Cambridge: Harvard University Press, 1956); Conrad Wright, The Beginnings of Unitarianism in America (Hamden, Conn., 1955, Archon, 1976).
} 
tunes "seem to have sprung involuntarily from the brains of (shall we say?)

possible poets." Her attempts to describe what she heard were that of an

intellectual nature. "The words were usually a fervent invocation, and the music

of a weird nature. I recall very little of them now only the chorus of one," she

wrote:

Roll, Jordan roll! Roll Jordan roll!

I want to go to Heaven when I die, to hear Jordan roll.

or

Swing low, sweet chariot,

I'm going for to carry me home.

The songs, inspired by events in the Old Testament and the book of

Revelation, expressed what the formerly enslaved people were forbidden from expressing while they were enslaved. Later, Carkin remembered that "these plantation songs became very popular from about 1870 for ten years or so, and some of my old pupils travelled to distant lands giving concerts consisting almost wholly of these curious musical waifs." 98 One of those students was Belle Gibbons. ${ }^{99}$ She later performed with the Fisk Jubilee Singers. Primarily, the group sung the spirituals they had sung during enslavement. Although the

\footnotetext{
${ }^{98}$ The words to "Roll, Jordan, Roll" can be found in William Francis Allen, Charles Pickard Ware, and Lucy McKim, compilers, Slave Songs of the United States, (Bedford, Massachusetts, Applewood Books), p. 1. The publication was the first comprehensive collection of slave songs. For the songbook used by the Hampton singers see Thomas P. Fenner, Cabin and Plantation Songs as Sung by the Hampton Students (New York: G. P. Putnam's Songs, 1876), Virginia Historical Society Archives.

${ }^{99}$ Belle Gibbons, daughter of Isabella and Reverend William Gibbons, taught in the public school system in Charlottesville before she joined the Fisk Jubilee Choir in 1884. See 1880 U.S. Virginia Census; Albemarle District 13/4. Also see Doug Seroff's "The Fisk Jubilee Singers in Britain," in Under the Imperial Carpet: Essays in Black History, 1780-1950, edited by Rain Lotz and lan Pegg (Crawley, England, 1986), 51. Also see Veit Erlmann, “'A Feeling of Prejudice': Orpheus M. McAdoo and the Virginia Jubilee Singers in South Africa, 1890-1898" Journal of Southern African Studies. 14 (April 1988), p. 333. Finally, Gayle M. Schulman's essay, "The Gibbons Family: Freedmen" in $\mathrm{MACH}$, volume 55, 1997, 61-94.
} 
circumstances had changed, the songs were remembered and performed nationally and internationally. The musical director at Fisk University said a "smoothing down " of the singers "voices was an accomplishment which came after long and hard labor." ${ }^{100}$ However, upon hearing them, many freedpeople felt the arrangements had lost its spiritual base. "Does are de same ole tunes, but some way dey do'n sound right" one formerly enslaved man lamented. ${ }^{101}$

Some of the work songs had been sung during slavery to ease the monotonous and repetitious labor. Carkin remembered "one autumn evening in Virginia hearing a peculiar and monotone kind of singing in the distance." She asked her servant, Margaret, what it was. "O, that's a corn song," Margaret replied and then explained that "somebody's having a corn shucking, and the men are singing the corn song." When the corn was ready to be husked it the farmers "made a huge pile out of doors and a few men set to work 'shucking' and singing the corn song." An essential component of the scene was whiskey which was always "liberally served on such occasions." The event would bring out "men and boys who heard the singing" and they "would follow the sound as the rats followed the music of the Pied Piper of Hamlin. Each one as he arrived on the scene, lent a hand to the shucking and a voice to the corn song, to say nothing of a thirsty throat to the whiskey."102 In the daily lives of the freedpeople, vestiges of antebellum communal activity continued.

\footnotetext{
${ }^{100}$ Lawrence Levine, Black Culture and Black Consciousness: Afro-American Folk Thought From Slavery to Freedom (Oxford University Press 1977), 166.

Levine, Been in the Storm So Long, 166.

102 Two corn songs are also found in William Francis Allen, Charles Pickard Ware, Lucy McKim Garrison, compilers, Slave Songs of the United States (Bedford, Massachusetts: Applewood
} 
Their weddings offer evidence of abiding within legal confines as well as exhibiting public expressions of devotion and love. These ceremonies were much more than fulfilling legal obligations. They were expressions of devotion and love, public acknowledgments that confessed a desire to establish an intimate bond with another. The matrimonial commitments of the freedpeople were deliberate acts of creating a new way of life. Carkin, however, claimed that the freedpeople imitated whites. "In the celebration of marriages, and the conduct of funerals, the ex-slaves took their cue from the white people, and aped their manners and style of dress, etc. as far as they were able." Her superficial gaze seems to look no more deeply than what she sees on the surface. Yet, in her words are cultural markers that define an important, though rarely examined, part of life: the value systems of a people as seen in their daily lives.

The freedpeople's African roots had persisted. During the antebellum period both black and white cultures had intimate contact with each other. Once freedom came, however, the bonds of intimacy and the balance of power changed dramatically. The expressive culture of freedpeople took form in their entertainment in song and dance as well as their personal appearance. Many thought of hair as an extension of their souls. It adorned the body and held the energy of a spiritual world. "Many of the colored women and girls would wind pieces of twine around locks of their woolly hair making it stand up all over their heads like little tails. The process was called 'wrapping' and was done to straighten it in a measure and really served to take out some of the kink, so that

Books, 1867), 68. Those songs are entitled, "Shock Along, John" and 'Round the Corn, Sally." Carkin, Reminiscences. 
on dress occasions they could arrange their locks more after the manner of white people." Carkin, not having any knowledge of the versatile nature of AfricanAmerican's hair, assumed that the 'wrapping' process was a function to approximate an Anglo-American image. She did not understand that 'wrapping' was a functional design form. Although its function was to make the hair more manageable the design was equally important. ${ }^{103}$ The design could signify one's status, whether single, engaged, married, childless, or a mother. As a social marker and as aesthetic expression, the dressing of one's hair evidences the retention of African customs. ${ }^{104}$

In other ways, one's personal appearance expressed individuality as well as liberation. Hats replaced bandannas, particularly on Sundays. Although head wraps, or geles, worn by women remained a part of everyday life, fewer women willingly wore them outside of the home, preferring instead to adorn their heads in more Anglicized fashions. This act seemed to shun the clothing of slavery; it can be argued, however, that freedwomen understood the need to merge into the dominant culture in ways perceived to be more American than African.

As cast-off clothing from New England arrived in barrels, men, women, and children frequently were seen picking through its contents in search of clothing that not only fit but also appealed to their esthetic taste. Carkin believed the "exslaves were every whit as fond of creature comforts as their white neighbors."

\footnotetext{
${ }^{103}$ Noliwe M. Rooks, Hair Raising: Beauty, Culture, and African American Women (New Brunswick: Rutgers University Press, 1996). See also Angela Fisher's Africa Adorned (1984). ${ }_{104}$ For a discussion of the significance and background of African American hairstyles see Roy Sieber and Frank Herreman, editors, Hair in African Art and Culture (New York: The Museum for African Art, 2000).
} 
She noted the variation in skin color and the ways people of color chose their clothing. "With a wonderful intuition as to what was becoming in dress, those of very dark skins usually affected bright colors - red and yellows predominately while those of lighter or very fair complexions were apt to select softer shades of color." Carkin recognized the destitution that many of them faced but she noted that "the style and color of their dresses was as always a matter of choice with them, as some poor creatures never knew what it was to have an article of clothing made expressly for them, but had to consider themselves happy if made comfortable in the cast off apparel of others more fortunate, and in such cases the question of color was necessarily second to the greater question of comfort."105

Piecing together a life after slavery meant that every aspect of life had to be refashioned. Freedom meant there was a need to find such basics as clothing and food. Carkin remembered, however, that they "often spent large sums which they could ill afford, to procure the clothing and food they considered necessary for a reasonable display on such occasions, and perhaps, nearly starved for weeks afterward to make up for the unusual display." Maybe her memory is that of the later reconstruction years, when freedpeople might have

\footnotetext{
${ }^{105}$ Catkin, Reminiscences. Patricia K. Hunt, "The Struggle to Achieve Individual Expression through Clothing and Adornment: African American Women under and after slavery" in Discovering the Women in Slavery: (Athens: The University of Georgia Press, 1996), 227-240. Linda Bumgarten, "'Clothes for the People': Slave Clothing in Early Virginia," Journal of Early Southern Decorative Arts 14 (November 1988), 26-70; Patricia K. Hunt, "Fabric Production in the Nineteenth-Century African American Slave Community," Ars Textrina 15 (1991), 83-92; Barbara M. Starke, "U.S. Slave Narratives: Accounts of What They Wore," in Starke et al., African American Dress and Adornment, 69-79. Another perspective on clothing and the Southern slave mistress can be found in Catherine Clinton's The Plantation Mistress (New York: Pantheon Books, 1982), 94-100. Regarding the production of clothing by slave mistresses see pages 2627.
} 
had discretionary income. Initially, however, the economic times did not easily support expenditures on clothing. Carkin critically noted, however, "in this they were no worse than many people of white skins."106

Faced with the remnants of war, both black and white Southerners created ways to negotiate the new cultural landscape. In February 1866 Southern state legislators enacted the "Black Codes" chilling the political winds as new rules and regulations to restrict blacks swept across the South. Each state had its own system. In Virginia, for example, legislators clarified the definition of vagrancy. Those blacks who "refused to work for the usual and common wages given to other laborers" were faced with one of several punishments. They could be "whipped, placed in pillory, and sold for up to one year's labor."107 Although disparity regarding the Black Codes existed throughout the South, the core element remained the same: to restrict the mobility of black people. The freedpeople's experiences regarding the new restrictions also varied throughout the localities.

Central Virginia did not experience the unemployment that many federal officials noted in their reports elsewhere. To the contrary, Carkin recalled the activity of the freedpeople as the train pulled into the depot at Gordonsville. "It was curious to see the crowd of colored men, women, and children who seemed to spring out of the ground, as it were, each individual bearing aloft a tray of eatables." Their initiative and the presence of men, women, and children engaged in the creative use of their labors reveals an aggressive and industrious

\footnotetext{
${ }^{106}$ Carkin, Reminiscences.

107 Eric Foner, Reconstruction, 200.
} 
people willing and ready to meet the demands of the market place. "They flicked about the car windows vying with each other in their efforts to secure the attention of the passengers," Carkin noted. As they moved about the platform selling their wares to a captive group of potential buyers, the freedpeople's direct glances at the passengers underscored their competitive nature. "'Have a snack! Nice fresh snack!' came from many pairs of lips at once, while as many pairs of eyes threw beseeching glances upon the faces of the passengers inside." In addition to their presence at the depot, their voices lent another dimension to the emancipation experience. No longer silent or mumbling, freedpeople expressed themselves in a variety of ways. These multiple layers of emancipation were quite different from the preconceived picture of lazy and childlike former slaves waiting for the Yankees to instill in them a sense of industry. ${ }^{108}$

Upon her arrival in Charlottesville, Carkin asked several white women to direct her to the Delavan where Anna Gardner lived and worked. Repeatedly rebuffed, she finally asked a black person, who directed her. She gazed "upon the broad piazza of an immense brick building, the exterior of which struck me as being in an advanced state of dilapidation." Entering the building, Carkin stood in "a wide hall, the doors of which stood open, passed through the centre terminating in a door at the rear, with a corridor running from midway to the left. At the right of the hall the whole lower floor formed one large room. At the left were four square rooms."109

\footnotetext{
${ }^{108}$ Carkin, Reminiscences.

${ }^{109}$ lbid.
} 
After meeting with military officials and Anna Gardner, "a room was given me on the second floor." Except for "a bedstead made of short pieces of timber" and "a primitive sort of wash stand," the room was bare though a fireplace "stretched across a corner of the room." Someone "brought me a wooden chair, a small square table of the same rude style, a washstand and a short bench."110

Leaving the comforts and familiarity of home, Carkin, like many other female teachers, sought out an opportunity to enrich her life as well as the lives of others in ways she could not have done had she remained in the Massachusetts school system. "I unpacked my trunks, made up my bed, having brought bedding for the purpose, hung up my dresses on nails that were driven in the wall, put some books and small articles on the broad mantel piece and sat down feeling quite at home. I had come out expecting rough living and should have been truly disappointed had I found home comforts and luxuries."111

Although Charlottesville was considered a cultured and refined town it was far cruder than Boston. "There was no adequate water supply, wells being the sole dependence in this respect, and one well often had to serve for several families. The water was very good, however, and was bought into the houses in pails or

\footnotetext{
${ }^{110}$ lbid.

"I Carkin, Reminiscences. By the middle of the -nineteenth century the growing middle class could purchase stylish factory-made fumishings available in matching suites. A parlor suite was likely to include a settee, a side chair or two, a gentleman's chair and a lady's chair. Fumiture was gender specific. A lady's chair featured a low back and an obvious lack of arms in order to accommodate the voluminous yards of fabric in Victorian dresses. A gentleman's chair sported a high back and arms, symbolizing the elevated status of the "man of the house." Renaissance Revival-style fumishings were introduced during the 1860s and were quite large and bold in appearance. Primarily crafted of walnut, this style featured carved or applied medallions, scroll work, pediments and carved fruit drawer pulls. Until the mid 1870s, advice manuals recommended that all the fumishing in any given room should match or be the same style. Also see Eileen M. Plante, Women at Home in Victorian America (Facts on file, 1997).
} 
pitchers by servants, who often carried these vessels on their heads."

Witnessing the continuance of a tradition common among African women, Carkin recalled that "I have seen the woman who worked for us bring three full pails of water at one time - one on her head and one in each hand." ${ }^{112}$ The freedwomen's efficient use of the body enabled them to compensate for the inefficiency of the built environment. "The dwelling houses, as far as they came under my observation, were not generally constructed with an eye to convenience in the same degree as houses of the same class in the North." In an effort to prevent fires from burning down the domicile, "kitchens were usually small separate buildings in the rear of the main house." Carkin recognized that "very little thought seemed to have been given to the idea of making one's labors light."113

Like other Northern commentators, Carkin made a connection between slavery and the laziness it incurred upon whites. She claimed that whites "who had no practical knowledge of household labor themselves, and who with their numerous slaves could see no occasion for labor saving-conveniences," were thoughtless and wasteful, "and so the work was done, in what seemed to us a very hard as well as slip-shod way."114

\footnotetext{
${ }^{112}$ Plantation wells for underground water and cisterns for the storage of rainwater usually were roofed. See K. Edward Lay, The Architecture of Jefferson Country (Charlottesville: University of Virginia Press, 2000), 69. Not until the mid 1880s, however, did Charlottesville's residents construct a municipal waterworks. See Moore, Albemarle, p. 247. 113 ibid.

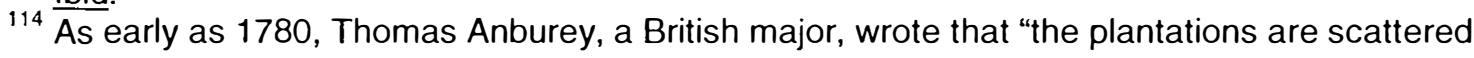
here and there. On these there is a dwelling house, with kitchen, smokehouse, and other outhouses detached." See Edgar Woods, Albemarle County in Virginia, (Harrisonburg, Va., 1900 , reprint 1972), p. 39. Camille Wells research in eighteenth century architectural history showed that kitchens, dairies smokehouses, slave quarters, barns and tobacco houses were the
} 
Black people, however, were not the only ones who found life difficult. "A little way to the west of Charlottesville, among the Ragged Mountains lived a class of people known as 'poor whites."' As early as the 1830s, popular culture had provided images of a marginal group who, though white, still were shunned by white society. In a hierarchical society their place remained fixed after the war. Carkin, having only seen depictions of them, claimed "they were exactly as one sees them represented in pictures or on the stage - long, lank, with straight unkempt locks and nondescript clothes. I would often see a whole family - man, woman, and several children come up the railroad track together on a Saturday morning each with a pail of meagre looking strawberries to sell."115

The interdependence of town and country could be seen in the most basic areas of daily life. Carkin recalled that, "The markets also seemed to depend upon the local country supplies for meat, vegetables, butter, eggs, etc. We could rarely get good beef, and the flesh of the scavenger swine had no temptation for us, but the mutton, lamb, and poultry were excellent." Across the county the cost of living was high. "In those early years all provisions were very high. I remember I paid 25 cts a pound for granulated sugar, and $40 \mathrm{cts}$ for raisins. Milk was ten cents a quart, and very blue and creamless at that. I could get no salt pork such as we have in the North - everything was bacon." Adjusting to their new environment, at times teachers found themselves forced to change their diets.

most frequently mentioned outbuildings. Ninety percent of the houses were of wood-frame construction. See Camille Wells, "The Planter's Prospect: Houses, Outbuildings, and Rural Landscapes in Eighteenth-Century Virginia," Winterthur Portfolio 28, I (Spring 1993).

${ }^{115}$ Carkin, "Reminiscences." 
"Sometimes the country roads would be impossible for days at a time and there would be a famine in such articles as fuel, fresh meat, poultry, butter, eggs and milk. "I never learned whether there was any regular system for taking care of the streets, but all the highways in and about the town were in a very poor condition." Town residents were exempt from county taxes for the upkeep of roads only if they kept their streets in good repair. "Outside the more populous part of the town the side walks were usually of plank and always more or less broken and dilapidated, and the unpaved streets after a heavy rain would be a mass of sticky mud. Wheels would sometimes sink nearly to their hubs, and the poor horses had a hard time dragging themselves and their loads through it."116 In addition to horse-drawn conveyances, rail travel linked Albemarle and Charlottesville's residents to the larger world. "Railroad accommodations were not very good at that time. The Orange and Alexandria R. R. extended from Washington through the town to Lynchburg and the Virginia Central from Richmond through Charlottesville to Staunton - perhaps farther. These roads formed a junction near our school, and I think used the same track to Gordonsville where the lines separated again. There were only two passenger trains per day each way on either road, passing through both ways near seven and midnight." 117 The arrival of the railroad in Albemarle County in the mid-

\footnotetext{
${ }^{116}$ In 1851 the Virginia General Assembly urged taxpayers to underwrite partial cost of paving streets near their homes. During the following decade this act was altered slightly. In 1859 with a vote of nearly six to one Charlottesville residents agreed to levy taxes not exceeding $\$ 3,000$. They also voted to borrow up to $\$ 5,000$ for general improvements throughout the town. The highest priority was given to grading and macadamizing Main Street. A committee suggested that the sidewalks be paved at the same time. Moore, Albemarle, p. 164-65.

${ }^{117}$ Louisa Railroad Company, also known as the Virginia Central, was the first rail line in Albemarle County in the late 1840s. The westbound from Gordonsville arrived in Charlottesville
} 
nineteenth century encouraged the construction of hotels at depots to accommodate rail travelers. Price's hotel was one of the earliest, built around 1850 on the Virginia Central Railroad. In addition to hotels, the county court licensed seventeen taverns throughout Albemarle County by $1860 .^{118}$

"I never heard that there was any law regulating the sale of liquors, so every grocery was a liquor store as well. The drinking habit was almost universal and persons in a state of beastly intoxication was a common sight on the street." One of the shopkeepers who sold liquor was W. D. Perry, who claimed "Let the world say what they can, for selling fine liquors - Perry's the man!" ${ }^{119}$ Winemaking became one of Charlottesville's major industries, alongside wool milling and shoe manufacturing. The Monticello Wine Company was chartered in 1873. Located on a hill at the end of Wine Street near Hedge Street, it became the largest in the South at that time. ${ }^{120}$

An act of the General Assembly in March 1851 had authorized the election of a mayor, four aldermen, and a town sergeant. The elected officials assumed all powers and duties formerly held and exercised by Albemarle's magistrates and sheriff within the limits of Charlottesville. In 1855 a firehouse was built on the

\footnotetext{
at 8:45 a.m. The train from Staunton arrived at 11:45 a.m. and left at noon. Freight trains went east on Monday, Wednesday, and Friday; west, on Tuesday, Thursday, and Saturday. After 1852 , the town of Charlottesville was served by the Orange and Alexandria rail line which utilized Virginia Central tracks as far as Gordonsville. By 1868, the Virginia Central had evolved into the Chesapeake and Ohio, crossing the county from Afton Mountain to Gordonsville. The Orange and Alexandria became the Southern Railway. In the late 1870s the Charlottesville and Rapidan Railway Company was organized for the sole purpose of constructing a direct link to Orange County. Moore, Albemarle, 188-89.

${ }_{118}$ Albemarle County tax lists, 1860.

${ }^{119}$ Woods, Albemarle, 171-72.

${ }^{120}$ Edward W. Hase II and Robert M. Hubbard, "Adolph Russow and the Monticello Wine Company," Magazine of Charlottesville History 46 (1988), 16-27.
} 
west side of Court Square and a fire engine was purchased from New York. Carkin, however, did not recall a firehouse, stating, "I think there was no fire company or any kind of fire apparatus in the town." ${ }^{121}$ Unwilling to move about the town and unable to believe that any type of municipal precautions existed, the freedmen teachers lived as though they had blinders on their eyes.

"There was one policeman, called the Town Sergeant, who was supposed to keep order in the place, and I think there were a few others detailed for extra duty, but street fights and rowdyism prevailed, and even murders were so common as to have lost the power of inspiring the horror they would in one of our Northern towns of like size."122 Carkin recalled that "more than once while we were in Charlottesville there were quarrels among the (University) students which ended fatally. Knives and pistols would be drawn upon the slightest provocation, but if a student were arrested and put into the jail his fellow students would batter down the doors and release him." ${ }^{123}$ The jailhouse held both town residents and University students who went astray of the law. "In what was called the 'University Burying Ground' we were shown the graves of two professors who were murdered by students."124

\footnotetext{
${ }^{121}$ K. Edward Lay, The Architecture of Jefferson Country 204. Moore, Albemarle, 164.

122 Moore, Albemarle, 163.

${ }^{123}$ Albemarle County built its fifth jail north of High Street in 1876 . The two-story high building had three-foot-thick stonewalls, a rough flagstone floor, a hipped roof with slate shingles, and two internal brick chimneys. George Wallace Spooner was the architect for the fifth Albemarle County jail. J. J. Gleason was the stonemason and Randolph Frank Harris was the ironworker. Not until 1880 did Spooner add a two-story section to the east side that had an eighteen-inch brick wall and an outside brick wall that formed a courtyard around the complex. See K. Edward Lay, The Architecture of Jefferson Country, 234.

${ }^{124}$ One of the professors, John A. G. Davis, was fatally shot by a student on November 12, 1840. See, John Hammond Moore, Albemarle: Jefferson's County, 138-9.
} 
The bold behavior of black and white males was particularly prevalent immediately following the war when issues of masculinity were at the forefront. Honor took on new meaning. ${ }^{125}$ Even "little boys" adopted the habits of older males. They "smoke and chew tobacco" and their teachers found it necessary "to take a firm stand against its use in school." Carkin also noted the "alarming habit of the male population" to carry pistols. "Even the colored boys soon acquired the habit" she recalled. "The rougher element among them (white males) showed a special spite towards any colored man or boy who was neatly dressed, usually knocking him from the sidewalk if nothing worse."126

Chivalry took on new relevance among black males. Carkin noted the difficulties black females endured as they moved about in public. "As for the young women and girls, many of whom were nearly or quite white, and some of them remarkably pretty - they were in constant danger of insult and abusive treatment, and the young colored men were frequently warned of punishment that would be meted out to them if they were rash enough to act as protectors of these girls by escorting them when it was necessary for them to go out in the evening." Determined to keep at least one segment of the formerly enslaved in "their place," white males continued to deny black women the status of a lady.

\footnotetext{
${ }^{125}$ Bertram Wyatt-Brown's study of antebellum Southern culture provides an excellent backdrop for understanding post-bellum (white and black) male behavior. Southern Honor: Ethics \& Behavior in the Old South (New York: Oxford University Press, 1982). Also see: Kenneth Greenberg, Honor \& Slavery: Lies, Duels, Noise, Masks, Dressing as a Woman, Gifts, Strangers, Humanitarianism, Death, Slave Rebellions, the Proslavery Arqument, Baseball, Hunting, and Gambling in the Old South (Princeton, New Jersey: Princeton University Press, 1996). ${ }^{126}$ Ibid.
} 
"If a young girl left unprotected in the evening reached her destination unharmed, she could well consider herself as cared for by a special Providence."127

The act of defending black women as well as the act of attacking black males who attempted to protect black women was a new battleground upon which chivalry and honor could be refashioned. "In these days when I hear so much of the crimes committed by colored men upon white women, 'wrote Carkin, "I hearken back to that time when I knew that any colored woman was looked upon (shall I say) a majority of the white men of the community as their rightful prey, and she was in a sense helpless and unprotected by the law as well as by public opinion." Citing the University as a hotbed of licentious activity, Carkin believed "that at the time I was there, there was nothing else in the locality that had so demoralizing an effect upon the colored youth of both sexes as our vicinity to the University of Virginia. Many of the growing [black] boys were employed by students as servants where they were pretty sure to receive an education of a most undesirable and vicious nature. And the girls - just released from slavery where their status was about the same as that of the domestic animals - is it any wonder that many of them were morally weak while all were practically defenseless?"

Although there was no law to protect black women, "I understood that there was a law protecting buzzards, as they were the necessary scavengers of the streets, and byways of the town. Dead dogs, cats, and other creatures were thrown on to some vacant lot for these loathsome birds to feast upon. There was

${ }^{127}$ Catherine Clinton and Nina Silber, editors, Divided Houses: Gender and the Civil War (New York: Oxford University press, 1992). 
very little pretense of effort to encourage public cleanliness and all sorts of refuse matter lay about unheeded. During my first years there cattle and pigs roamed the streets at will. Often the only subsistence of the cow of some poor person, was what she gathered at the roadside, and on open unoccupied lots. The swine were the efficient assistants of the buzzards as scavengers." ${ }^{128}$

Just before the war, Albemarle County had been at the forefront of livestock breeding and production in the state. "There was no law for the protection of dumb animals," Carkin observed, "and there seemed to be a deplorable lack of feeling in regard to their sufferings from the thoughtlessness and cruelty of their owners. Cows would wander about on the outskirts of the town all winter, nibbling the dead grass by the wayside or getting a slender feast from the sides of an occasional haystack. Mere skeletons, they seemed scarcely able to drag themselves about - without shelter in the coldest storms of winter. Horses were overloaded, overdriven and beaten without the slightest show of mercy. Slavery had hardened the hearts of both master and slave, and all animals had to suffer in consequence."129

Charlottesville was not as rural as Carkin seemed to think it was, though compared to Boston, it was a backward place. As early as 1840, commercial buildings proliferated west of downtown Charlottesville on Main Street. Following the war an economic depression and the increase in the number of bankruptcies slowed commercial activity as well as the construction of new buildings. Building activity did not fully resume until 1866 when Monticello Bank ${ }^{128}$ Carkin, "Reminiscences." 129 lbid. 
re-opened as the Charlottesville National Bank. A year later the Farmers' and Merchants' Bank began operations at 509 East Main while the Citizens' National Bank opened at 500 East Main. ${ }^{130}$

By 1860 the Albemarle County Court licensed seventy-seven retail businesses. When Philena arrived in Charlottesville shops and stores dotted Main Street from downtown to the University. Anderson Brothers' Bookstore at the corner near the University had been located at that site since 1852. Many of the commercial buildings evolved from two-story brickhouses with stepped gables, in which the owner lived above the store. R. A. Musgrove, who became a teacher to the freedpeople, operated a dry goods store with a partner on West Main Street. The second floor was used either for storage or as living space for the storekeeper and his family and oftentimes as lodging for travelers. Merchants, peddlers, and innkeepers were licensed annually by the county courts. "There were quite a number of grocerys (sic) and dry goods stores in town - two or three druggists and about the same number of jewelers."

Frederick M. Wills sold German cologne, stationery, and various pharmaceuticals. Burke Archer and Company advertised themselves as medical suppliers as well as sellers of high-end toiletries. In 1860 Fred Hartnagle sold a variety of items, as did his rival, Andrew Mannoni, who was located on the public square. J. W. Lipop, one of the jewelers, advertised the arrival and services of a Geneva-born watchmaker on his staff. Edward Benner also owned a jewelry

\footnotetext{
${ }^{130}$ Both banks closed after the national panic of 1873. Another bank, the People's National Bank, opened in 1875 at 401-3 East Market Street. Between 1870 and 1880 the number of small banks doubled.
} 
store. He sold an assortment of sterling and plate items, among them coffee urns, pitchers, and cake baskets. ${ }^{131}$

“There seemed to be no very extensive manufacturer in or about C'ville. All that I can now recall are the C'ville Woolen Mills - (the extent of which I never learned), and a brick yard which occupied the lot next to our school." The 1860 county census identified thirty-four grist mills and sixteen sawmills. Even during the Civil War a map of the county drawn in 1864 under the direction of Maj. General Jeremy F. Gilmer, chief of Confederate engineers, noted more than sixty-six mills including a steam sawmill in the vicinity of Buck Island Mills on the Rivanna River. In 1870 a flood demolished many mills and bridges. A county map published in 1875 by Green Peyton identified more than sixty-nine mills. According to the county land tax records, Charlottesville Mills, the highest-valued building in Charlottesville at that time, was assessed at $\$ 17,800$. $^{132}$

Education in Charlottesville had a long history. Both middling - and upperclass children were taught to read and write. The State Literary Fund, created in 1810 , was forward- thinking in its mission on two grounds. Initially created to educate the children of the poor, the fund also represented the first provision for state funds in Virginia to finance a statewide program of free schools. ${ }^{133}$ With instruction by parents, the clergy, or family tutors, white males from the planter class were assured of an education. Boys from the middling class learned the

\footnotetext{
${ }^{131}$ Moore, Albemarle: Jefferson's County, 1726-1976, 172.

132 David A. Maurer, Charlottesville Daily Progress, December 1, 1991; August 30, 1992; Albemarle County Tax Lists, 1870.

$133 \mathrm{~J}$. L. Blair, The Development of Public Schools in Virginia: 1607-1952, (Richmond, VA: State Board of Education), p. 29. Henry Allen Bullock, A History of Negro Education in the South. (Cambridge, MA: Harvard University Press, 1967) p., 47.
} 
rudiments enabling them to run their various enterprises with a modicum of academic training.

The Charlottesville Female Academy offered upper-class women an education as early as 1819. As many as thirty fathers "having many daughters and wishing them well educated," resourcefully acquired a building where their daughters could become members of the educated class. There were two annual sessions, each at a cost of $\$ 60.00$, which included fuel, washing, and board. Students learned geography, English, history, astronomy, use of globes, drawing of maps, and arithmetic. In addition, French and music were offered. ${ }^{134}$

Some enslaved and free blacks learned in a variety of ingenious ways. Often enslaved children would accompany their young charges to classes. These early patronage ties enabled blacks to secure basic literacy. Sometimes, an older adult in the black community would hold clandestine meetings to teach others to read and write. By and large, however, the majority of the black population was illiterate.

Carkin began teaching immediately, and just as quickly she noted the dogged determination of the students. "Many of our pupils came long distances - from two to five or six miles to school." Even as the students made the effort to "get a right smart education" they also labored in the marketplace. "I remember one boy of 18 or 19 years who lived five miles away, and attended school regularly although he had to earn his living by working at his trade - shoemaking in the evening." Carkin emphasized to her readers that the pursuit of education

${ }^{134}$ More, Albemarle, p. 103. 
involved "many others who made a similar struggle in order to enjoy the privilege of attending school."135

Adult students, both male and female, worked. They met and surpassed the mandates regarding vagrancy and in doing so enabled as many as possible to attain an education. "One old woman who did laundry work told me she kept her books on her ironing table and learned her lessons while she worked." Carkin speculated that the freedpeople "felt that the power of their white superiors lay in the education that had been denied them so they thought that no labor was too arduous and no sacrifice too great."

Both Gardner and Carkin continued to use their private rooms for instruction, filling their evenings as well as their days working with students. Carkin informed the NEFAS officials that, "I have them come to my room and read occasionally in the evening." Like freedmen's teachers throughout the South, neither Carkin nor Gardner interacted beyond a select circle of blacks and whites. Carkin's life was so bound by work she claimed that, "the time hangs heavy on my hands when I am out of school." Given the lack of a social life and also in an effort to meet the needs of all who came to her, Carkin found herself making decisions about her life to accommodate their needs. "I have planned to open a night school for such men and women as cannot study during the day on account of their occupations. I shall teach only three nights in a week." She also noted the drop in attendance due to economics. "Some few of my pupils have left." As employment opportunities shriveled, freedmen and freedwomen made no qualms about

${ }^{135}$ Carkin, Reminiscences. 
relocating. "One of my oldest girls has gone to Baltimore; and some of them have been obliged to leave school and engage in some remunerative employment."136

By April of 1866 the teachers wrote that Major Head had removed his command to other quarters and had turned over the "building formerly occupied as barracks to be used as schoolrooms for the freedmen."137 The military presence had offered a feeling of safety to the teachers and perhaps to some of the students. "The Major's Headquarters were in the Delavan where we had our first home, and the soldiers barracks were at first in the long building where we had our schools, but they were soon removed to the good-sized structure connected to the rear of the Delavan by a square platform: so we who were occupants of the house lived a kind of semi-military life. Carkin recalled that by the end of May, "orders had come for the troops to be removed from Charlottesville. The colored people were very much alarmed, and we felt that our position there would scarcely be secure without their protection, so with the approval of Maj. Head, the teacher, Miss Gardner, went to Washington to appeal to the authorities there to allow the soldiers to remain a while longer." Officials in Washington considered their request for continued protection but concluded that a military presence was no longer necessary. In recognition of the soldiers' service and protection both Anna Gardner and Philena Carkin "waved our

\footnotetext{
${ }^{136}$ The Freedmen's Record, vol. 2, no. 2, Nov. 1866. See Myra B. Young Armstead's work, "Lord, Please Don't Take Me in August": Newport and Saratoga Springs, 1870-1930 (University of Illinois Press, 1999). Armstead examines the work experiences and lives of African Americans in the locales to which they migrated.

${ }^{137}$ Ibid., vol. 2, no. 4, April 1866, p. 75.
} 
handkerchiefs as the train moved off." In return the soldiers swung their caps and "gave us three cheers." 138

On June 9, Carkin wrote, "the troops left this place two days ago." The next day, Anna Gardner stated her intention. 'We intend to hold our ground here, and we feel there will be no difficulty in doing so during the brief period prior to the closing of the school." The white people, Gardner claimed, would say that "relations between the white and colored people are so friendly here that the garrison is wholly unnecessary." Having little contact with whites themselves, neither Carkin nor Gardner could be certain of the state of race relations. They both decided to continue teaching nonetheless.

"The inner walls of the whole building were clap-boarded like the outside of a house. These walls were freshly whitewashed every year as long as we lived there, and the school rooms were decorated with wreaths and arches of evergreen which the boys would go out and gather at stated times when all hands would go to work to decorate. One huge wreath made on a barrel hoop was hung from the ceiling in the centre of the room. Arches were placed above each door and window, and large wreaths hung in the spaces between. The effect was very pretty and cheerful, taking away the grim unfinished look of the rough walls. We were too much interested in our work and too busy to let our imagination dwell upon the dark stains here and there upon the floors."

In their daily devotion to freedom, in the regular enactment of liberty, in their gatherings and celebrations, their religious and social observances, and their

${ }^{138}$ Carkin, "Reminiscences." 
very demeanor, the former slaves sought the best that life could afford them given their new realm of freedom. "Any thoughtful, unprejudiced person could not have lived among these people very long, without perceiving that all the seeming absurdities in dress, religion, etc., were the efforts of a people to adapt themselves as best they could to the circumstances by which they were surrounded, and a reaching our for something better than they had known."139

\footnotetext{
${ }^{139}$ Carkin, Reminiscences. The field of scholarly explorations on memory and history is growing. Benedict Anderson, in Imagined Communities: Reflections on the Origin and Spread of Nationalism (1991) examines nationalism as a changing construction. David W. Blight, in Frederick Douglass' Civil War: Keeping Faith in Jubilee. (Baton Rouge: Louisiana State University press, 1989), examines Douglass's memory of the Civil War. David Thelen, editor of Memory and American History (Bloomington: Indiana University Press, 1990) discusses how memory is constructed and affected by factors such as "present needs" and "new understandings."
} 


\section{Chapter Four: Harvesting the Future}

Through Miss Anna's patient teaching, and the help of God, we have improved so much that we almost think ourselves educated. ${ }^{140}$

At the close of her first formal year of education, 12-year-old Celia Rosena Wood, cognizant of her own intellectual growth, wrote to the members of NEFAS. She had begun to see herself outside of her past condition as a slave. As "Miss Anna's" student and a child of God, little miss Celia recalled an earlier time when she had not been allowed to even look at books. "Several years before the war I lived with a lady who had the power to prevent me from having anything to do with books; she said the books were not made for negroes, but they were made for her children." Celia's mistress "had two young daughters who were going to school." The mistress was hard pressed but determined to educate her daughters. "She said it was enough for her to buy books for them" and her generosity and determination did not extend to her servant, Celia. ${ }^{141}$

The memories of life under slavery would leave neither quickly nor easily.

They linked the past with the present, clinging to each move, each thought and lurking around the corner as if they were a part of the person. Their power to keep one mired in the past or to propel one forward remained to be seen when

\footnotetext{
${ }^{140}$ Freedmen's Record, vol. 2, no. 7, July 1866, p. 131.

141 Celia Wood, The Freedmen's Record, vol. 2. No 7, July 1866, p. 131. Freedchildren throughout the south began to think differently about their lives. One freedperson at Fortress Monroe said the black schoolchildren thought getting an education "was so much like the way master's children used to be treated, that they believed they were getting white." See Elizabeth Hyde Botume, First Days Amongst the Contrabands. (Boston, 1893), p. 259. For a detailed account of childhood under slavery see Wilma King, Stolen Childhood-Slave Youth in Nineteenth Century America (Bloomington, Indiana University Press, 1998). Also see Marie Jenkins Schwartz, Born in Bondage: Growing Up Enslaved in the Antebellum South (Cambridge: Harvard University Press, 2000).
} 
Celia Wood and others recalled their experiences. What steps should they take? They had no pattern to follow, no guide to lead them, no plan to implement, yet they did make a way. ${ }^{142}$

Most historians speak of the desire of the freedpeople to get an education. Yet, it was more than desire that brought them in droves to makeshift schoolrooms. They had made a decision based on their past experience as an enslaved people. Having been denied the opportunity to be educated in a society that valued education had taught them that this particular aspect of freedom held great value. They acted as rational, thinking people; a people who had observed the benefits of education. Their collective decision pushed them to pursue this valued commodity with a fierce determination. They not only consumed education, they invested in it; securing a wealth that could not be ripped from them.

When Anna Gardner and Philena Carkin returned to Charlottesville on October 1,1866 , after their annual vacation, they found themselves in a "drenching rain." Later that evening when Gardner sat by her fireside she captured her feelings on paper. "We felt ourselves much favored; and the contrast, between that warm reception and what I experienced a year ago on my arrival at this place, was great indeed." This year she and Carkin had "found a covered carriage awaiting our arrival (a carriage owned and driven by one of my adult scholars) and another scholar, one who is always foremost to help us, was

\footnotetext{
${ }^{142}$ Schwartz, Born in Bondage. For a brief discussion of literacy see pp. 150-154, 185.
} 
standing upon the platform ready to take our checks." No longer fearful of recrimination, the freedpeople had transcended their subservient past. ${ }^{143}$

Drawing on their own observations and experiences, blacks saw the link between literacy and power. Across the South, freedpeople thronged to makeshift schoolhouses, besieged Yankee schoolteachers, and made monumental sacrifices in order to be part of something they recognized as valuable. Even freedchildren recognized their new opportunities and parents made great sacrifices to see that their children received an education. At the end of September, Carkin noted the school's growth: "I opened school Wednesday with about thirty seven pupils, which number has gradually increased to sixty."144

As the agrarian landscape demanded its time the teachers learned to adjust to the unfamiliar terrain on which they now found themselves. Making concessions for habitual late-comers, the teachers calculated that, "there are about five or six more belonging to the school who have not come in yet." Carkin believed they would "be able to attend in about one or two weeks." 145 Despite the many hardships they endured, students continued to invest their time as well

\footnotetext{
${ }^{143}$ Freedmen's Record, vol. 2, no. 11, Oct. 1866.

144 Freedmen's Record, vol. 2, no. 11, Oct. 1866.

$145 \mathrm{lbid}$. Booker T. Washington recalled that his mother told him whites considered reading a dangerous practice for blacks to cultivate. "From that moment I resolved that I should never be satisfied until I learned what this dangerous practice was like." When Washington finally had the opportunity to enroll in a freedmen's school, he continued to work five hours in the morning and two hours after classes in the salt furnaces. Washington's work demands interfered with his schooling until he enrolled in the night school where he acquired "the greater part" of his elementary education. See Louis R. Harlan, Booker T. Washington: The Making of a Black Leader, 1856-1901. (New York, 1972). Booker T. Washington, Up from Slavery: An Autobiography (New York, 1902).
} 
as their dollars in education. "The scholars here pay very promptly for all their books, and have from the first, with only a few exceptions."146

Most of the students, male and female, young and old, worked. Eschewing charity, freedpeople as well as children invested in education through their work in and out of the school. ${ }^{147}$ "The work of taking care of the schoolrooms was performed by the pupils under the supervision of the teachers" Carkin recalled. "The girls did the daily sweeping and dusting, and the boys cut the wood, and made the fires. When there was a regular cleaning up the boys and girls were both pressed into service." With pride, Carkin spoke of "some young men in the school who are sufficiently acquainted with the carpenter's trade to do all that is necessary to keep the building in very good repair."

By December 1866, Carkin informed NEFAS that the local Freedmen's Aid Society "had a very successful meeting last Wednesday night." Increasing their supporters and coffers, the "freedpeople admitted thirty new members" and collected "fifteen dollars in one evening"149 Initially, however, Carkin stated that the society had "failed to come up to the mark as yet." Overlooking the economic hardships that freedpeople endured, Carkin believed the society's failure was "partly owing to the bad habit of procrastination, which is so prevalent here." Carkin also believed another reason the group was not successful was "because

\footnotetext{
${ }^{146}$ The Freedmen's Record, November, 1866, volume 2, no. 11.

147 See Amy Dru Stanley "Beggars Can't Be Choosers: Compulsion and Contract in Postbellum America," The Journal of American History (March 1992), pp. 1265-93. Stanley explores how legislators reconciled a system of compulsion with the ascendant doctrine of liberty of contract. Also see Lori D. Ginzberg, Women and the Work of Benevolence: Morality, Politics, and Class in the Nineteenth-Century United States (New Haven, 1990), 133-212.

${ }^{148}$ Carkin, "Reminiscences."

${ }^{149}$ Carkin “Reminiscences." Freedmen's Record, vol. 2, no. 12, December 1866.
} 
we cannot teach all who wish to come." Carkin recalled that when she arrived "in the spring of 1866 , the various schools that had been opened for the benefit of the Freedmen were wholly independent of each other. Each teacher admitted as many pupils as he or she could accommodate without regard to educational qualifications." 150 Turning away "children from six to ten years of age," who "will have some years to study, and probably a much better chance than the older ones had before them," Carkin again superseded her role as a teacher. "I have tried to do the best I could for them by taking such as I knew would have but a short time to go to school - those from fifteen and upwards." She was aware that "parents of those children whom we were obliged to refuse will not do anything towards helping on the school." In an effort to help those they could not teach, Carkin and the other teachers "encouraged our more advanced pupils to impart what they learned in school to their less favored friends." ${ }^{151}$ By 1867 Gardner informed officials that the Educational Society "is in a flourishing condition, and furnishes without stint all that is required to keep our schools in a comfortable condition." Throughout the localities parents and groups of parents raised funds to support the schools, exhibiting strong signs of collective self-help.

Freedpeople appreciated the opportunity to share. They held literacy in high esteem, making sacrifices to educate at least one in every family. ${ }^{152}$ Gardner recalled that one member of the freedmen's group said "Who would have thought, three years ago, that a time would ever come in Virginia, when there

\footnotetext{
${ }^{150}$ Freedmen's Record, vol. 2, no. 4, April 1866.

151 Freedmen's Record, vol. 2, no. 11, Oct. 1866.

152 Census records indicate a high percentage of households with at least one person within the household unit attending school.
} 
would be a meeting of negroes, called to confer on the subject of preparing a room in which their own people could be taught the mysteries of reading and writing." 153

Encouraged by the students' progress, Anna Gardner solicited help from J. C. Southall, the editor of the Charlottesville newspaper in the spring of 1867. "Having heard colored people speaking of you as a true friend to the cause of education among them, I take the liberty, on their behalf, of requesting you to make a donation to the Jefferson School, in the form of printed diplomas, stating that the graduate is qualified to commence teaching the rudiments of an English education, \&c." Days later Southall replied, expressing his "interest in the welfare of the negro race." He expressed concern, however, because "the impression among the white residents of Charlottesville is, that your instruction of the colored people who attend your school contemplates something more than the communication of the ordinary knowledge implied in teaching them to read, write, cypher, \&c." Denouncing Gardner's activities still further, he stated, "the idea prevails that you instruct them in politics and sociology; that you come among us not merely as an ordinary school teacher, but as a political missionary." Seeing her role as a threat to Southern society, Southall railed, "You communicate to the colored people ideas of social equality with the whites." However, he informed her, if what he had said was untrue he would gladly help her. Gardner shot back, "I teach in school and out," thus clarifying her position

${ }^{153}$ The Freedmen's Record, vol. 3, no. 3. March 1867. 
as a teacher, reformer, and social activist. ${ }^{154}$ Moving beyond her role as a teacher in the classroom, Gardner became a catalyst for change in the larger community as she articulated the needs of her students and their school.

Southall had reason to be concerned. The Civil Rights Act of March 1866 had legalized freeedmen's testimony in court. Noting its passage, Carkin wrote, "the recent good news from the North shows that the political sky is clearing and very encouraging to us indeed." ${ }^{\text {155 }}$

A year later, on March 2, 1867, the Military Reconstruction Act blended Radical and Moderate elements. As a result, neither group could control Congress. The act declared that no legal state governments existed among the ten seceded states. The act also divided the South into five military districts, each under the control of a military commander backed by a small contingent of troops. The military commanders were authorized to use military tribunals in place of the civil courts (which were controlled by local whites) if necessary to maintain order and protect the "rights of persons and property."

The primary task of the district generals was to prepare the states under their authority for readmission to the Union. Isabella Gibbons wrote, "We have lived to see the fortieth Congress and to behold a change of affairs."156 Congress had pushed through three measures that would determine subsequent events. Many Radicals, such as Thaddeus Stevens, leader of the Congressional Radical Republicans, wanted to give black males the right to vote, disenfranchise former

\footnotetext{
${ }^{154}$ The Freedmen's Record, vol. 3, no. 4. April 1867.

${ }^{155}$ Carkin, The Freedmen's Record, vol. 2 no.11, November 1867.

${ }^{156}$ Isabella Gibbons, The Freedmen's Record, vol. 3, no. 6, June 1867.
} 
Confederates for the foreseeable future, provide public education for blacks, and confiscate former rebel land and redistribute it to freedpeople. Other radicals, like Charles Sumner, gradually adopted a sympathetic attitude toward the South, though Sumner still advocated education for blacks. But Moderates were unwilling to go so far. Racism restrained them; in addition, they were also concerned for the rights of property owners and the basic commitment to majority rule in the various states.

The social changes that occurred at the local level went hard on the native whites. Paul Lewis, a former slave who by now had become a teacher, wrote, "It is very strange to the white people here to see a colored man acting as a teacher."157 The range of feeling among whites varied. Some found it difficult to accept blacks in new positions. Gardner continually encouraged her students, telling "them that the Boston Society are looking to this school for a harvest of teachers," which she believed acted as "as a healthful stimulus to their already awakened ambition."158

By the beginning of the fall term, NEFAS officials were able to inform readers about the progress in Charlottesville. The schools were "graded into three classes, comprising about one hundred and sixty scholars in all." Of these students, thirty-three "belonged to the advanced class which Anna Gardner taught "two sessions, six hours per day." The other classes, taught by Philena Carkin and Isabella Gibbons, were on the order of the New England School system as much as possible. "Our schools are all taught in one building" and the

\footnotetext{
${ }^{157}$ Paul Lewis, The Freedmen's Record, vol. 3, no. 4. April 1867, p. 59.

${ }^{158}$ Carkin, The Freedmen's Record, vol. 2, no. 12, December 1866.
} 
furnishings "consisted of rough benches without backs and a few rough tables doing duty as desks."159

The deteriorated condition of the school spurred the teachers and students to make economic decisions. After only a few days into the school term, inclement weather forced Carkin to close her school. In explaining her decision to Mrs. Cheney, Carkin demonstrated the hardiness freedmen teachers needed. "My school room was flooded with water owing to some defective shingles." In addition "we have also suffered much from the cold." Making a decision, Carkin "called the school together," informing her students "they must tell their parents that we would not have school any rainy or cold days until the leaks were stopped and the rooms furnished with stoves."160 Carkin learned there were "stoves at Gordonsville" which could be had for the freedmen's school. She made arrangements to remedy the poor condition of the schoolroom, telling her students that once the funds were collected "we would send for the stoves and perhaps there would be some money left to help towards fixing the school room." Weather conditions forced Carkin to make a decision affecting the attendance once again. On October 30, Carkin was "obliged to suspend the school for a few days, owing to very rainy and cold weather." At that time the school had not received "stovepipes and wood." Carkin "held a meeting of parents at the schoolroom, and explained the whole matter to them again." As a

\footnotetext{
${ }^{159}$ Carkin, "Reminiscences."

${ }^{160}$ Freedmen's Record, vol. 2, no. 11, Oct. 1866, p. 199.

161 Freedmen's Record, vol. 2, no. 11, Oct. 1866, p. 199.
} 
result of her efforts, she proudly proclaimed, "twelve dollars were collected."162 Whether Carkin received permission from Mrs. Cheney or any official at NEFAS, when she "told each scholar to bring ten cents Monday morning," is unknown.

When asked about the ten-cent tax required from each student, Carkin noted the sacrifice of one working mother. "There are some who could pay more, but there are others who find even that small sum difficult to raise." Economically strapped but still willing to make sacrifices in order to educate their children, parents endured various and numerous deprivations. "There is one poor woman who sent five children. She is a seamstress with poor health and failing eyesight. She had two cows which she sold in order to raise money to send her children to school this year." Acting with autonomy, Carkin " allowed her to send one without the tax." Operating within systems larger than themselves, both freedpeople and teachers weighed their options and made decisions while expanding their horizons and pushing the boundaries that had become more elastic since the war. "Another woman who supports her three children by washing and ironing I allowed to send a little girl free of charge, for as they have neither sufficient food nor clothing I knew that even that small sum could not be paid." In waiving the ten-cent tax Philena had enacted another, more personal, kind of freedom. Had she remained in Massachusetts to teach she would not have realized the "power to do" as the freedpeople claimed of their experience. Within this reciprocal web students and teachers struggled to change their lives.

${ }^{162}$ Freedmen's Record, vol. 2, no. 12, Dec. 1866, p. 213-14. 
Throughout the South, former slave-owners complained about the withdrawal of freed women and children from the fields. One bureau officer in Charlotte County noted distinctions between black men and women in the labor force. "One of the strangest developments of negro character under the free system is their indisposition to work their wives and children."163 The agent believed that freedmen should compel black women to work. White employers also refused to acknowledge the labors of freedwomen and children in any areas that did not directly benefit the former slave economy. ${ }^{164}$ Instead, they presumed, the withdrawal of women and children was due to idleness.

Whenever possible, freedwomen sought work that enabled them to meet their self-defined needs. At times, freedpeople had to decide whether they would attend school or work. "I have three or four girls, who are obliged to absent themselves from school one day in a week," Carkin informed her superiors. Recognizing the needs of her working students, Carkin asserted, "I do not feel right to tell these girls that they cannot be permitted to come to school in this way, from the fact that they are good steady scholars in every other respect." Extended families took in family members and especially children; those old enough to work were expected to contribute to the household. Carkin remembered one of the girls who was obliged to earn her keep. She "has no parents and lives with an aunt who makes a perfect slave of her." In addition to

\footnotetext{
163 Jeffrey R. Kerr-Ritchie, Freedpeople in the Tobacco South: Virqinia, 1860-1900 (Chapel Hill: University of North Carolina Press, 1999), p. 60. Lt. Lyon to Col. O. Brown, April 30, 1866, Monthly Report by BRFAL official, in RG 105.

${ }^{164}$ Peter Bardaglio, Reconstructing the Household: Families, Sex, and the Law in the Nineteenth Century South (University of North Carolina Press, 1995).
} 
household duties, this student also worked in a family business. "Her uncle keeps a restaurant, and she is often compelled to be up as late as twelve or one o'clock at night cooking and waiting on customers."165 Carkin's mission expanded as she helped her students support themselves while they completed their education. Concluding her letter, she informed the officials "two of them are nearly fitted to teach and if they could not have the one day they would be obliged to stop school altogether." As society changed, so, too, did black women's expectations of what their lives could be without the weight of slavery's chains holding them down. ${ }^{166}$

Isabella Gibbons, in particular, caught the attention of Gardner. The student that Anna Gardner tutored had become a budding scholar. "Mrs. Gibbons (a colored native teacher) is very much liked by the colored people here." Thinking of Isabella Gibbons' effect among the freedpeople, Gardner intuitively recognized that Gibbons' "nature is so noble, that she is not so liable to stimulate petty jealousy among her people as many might under similar circumstances."

Because of these qualities and more Gardner informed NEFAS officials that Mrs. Gibbons "will therefore be more likely to be useful."

When Gibbons began teaching "on the 3d of October with forty-two scholars," she "read a chapter in the Bible, choosing the eighty third psalm" which she

\footnotetext{
${ }^{165}$ NEFAS letters, Carkin to Cheney, December 4, 1874.

166 Laura F. Edwards, Scarlett Doesn't Live Here Anymore: Southern Women in the Civil War Era (University of Illinois Press, 2000); Peter Bardaglio, Reconstructing the Household: Families, Sex, and the Law in the Nineteenth Century South (University of North Carolina Press, 1995).
} 
insightfully believed was "suitable for the times." 167 In addition to political and judicial changes, labor adjustments and race riots stymied race relations. Earlier that year, constitutional amendments had been discussed, revised, and introduced to the Senate. The Joint Committee of Fifteen drafted an amendment to protect the citizenship of blacks. The Fourteenth Amendment passed Congress. Riots occurred in Norfolk, Virginia, New Orleans, and Memphis. Broken labor contracts between freedpeople and their white employers also hindered progress. In the fall elections of 1866 the Republicans had captured two-thirds of each house, giving the Radicals effective control of Reconstruction. ${ }^{168}$ Shifty politics prompted Gibbons to select a passage that spoke to the needs of a besieged people. Invoking Psalm 83 allowed Gibbons to cloak her anger with biblical justification. Soliciting spiritual help against those who would be against the upward mobility of the freedpeople, Gibbons' role as a teacher to "sixty-three students" became that of a leader. "I then told them (the

\footnotetext{
${ }^{167}$ The King James Version of Psalm 83 follows: "Keep not thou silence, O God: hold not thy peace, and be not still, O God. For, lo, thine enemies make a tumult: and they that hate thee have lifted up the head. They have taken crafty counsel against thy people, and consulted against thy hidden ones. They have said, Come, and let us cut them off from being a nation that the name of Israel may be no more in remembrance. For they have consulted together with one consent: they are confederate against thee: the tabernacles of Edom, and the Ishmaelites; of Moab, and the Hagarenes: Gebal, and Ammon, and Amalek; the Philistines with the inhabitants of Tyre; Assur also is joined with them: they have holpen the children of Lot. Selah. Do unto them as unto the Midianites; as to Sisera, as to Jabin, at the brook of Kison: Which perished at Endor; they became as dung for the earth. Make their nobles like Oreb, and like Seeb: yea, all their princes as Zebah, and as Zalmunna: Who said, Let us take to ourselves the houses of God in possession. O my God, make them like a wheel; as the stubble before the wind. As the fire burneth a wood, and as the flame setteth the mountains on fire; So persecute them with thy tempest, and make them afraid with thy storm. Fill their faces with shame; that they may seek thy name, O Lord. Let them be confounded and troubled for ever; yea, let them be put to shame, and perish: that men may know that thou whose name alone is JEHOVAH, art the most high over all the earth." David Donald, The Politics of Reconstruction, 1863-1867 (Harvard University Press, 1984).

${ }^{168}$ David Donald, The Politics of Reconstruction.
} 
students) I wanted they should conduct themselves so as to reflect credit on the school and their race, in education, and by moral improvement."169

Gibbons took on the additional responsibility of training with her teacher, Anna Gardner, "in the evenings." Reallocating her household responsibilities to her older offspring, Gibbons governed both domestic and professional spheres with agility. Reflecting on Gibbon's new status as teacher, Gardner said "I think she is doing well in her new sphere of duty, especially in the matter of government." Gardner especially thought Gibbons' personal attributes helped her succeed. "She has a kind of magnetism about her, which is a good qualification for a teacher." Indeed, her ability to read aided her professionally and helped Gardner rank her abilities. "She is really a fine reader of easy readings, and I should choose her, to prepare scholars for me in that line, from among nine-tenths of those engaged in this work, so far as I have known." So impressed with her pupil, Gardner effused, "you will never have cause to regret having employed her."170

When NEFAS wrote its annual report the officials noted with pride Gibbons' "recent appointment as a teacher of her race being an experiment as to how a colored woman, who had been a slave up to the time of the surrender, would succeed in a vocation to her so novel." Indeed, her success seemed "almost a miracle." The officials also noted her management of the school, "and of governing it without resorting in any instance to severity of discipline."171

${ }_{170}^{169}$ Freedmen's Record, vol. 2, no. 11, Nov. 1866.

170 Freedmen's Record, vol. 2, no. 11, Nov. 1866, p. 201.

171 Freedmen's Record, vol. 2, no. 12, Dec. 1866, pp. 213-14. 
One method of corporal punishment that had been frequently used in schools was feruling, or hitting the palm of a hand with a ruler. Nineteenth-century educational reformers argued that the teacher should use the ruler or rod as a last resort. The subject of corporal punishment in Boston schools had been raised several times by the Boston School Committee. Members suggested that "a regulation to define the nature of corporal punishment " was needed. They also questioned whether the practice should be abolished altogether. A committee of five was appointed to investigate the matter. After a two-year period the committee determined that girls should not, in any case, be subjected to corporal punishment. "Provision was also made, as to the instrument which should be used in punishing corporally, and the manner of its application. Nothing of this nature had existed before." The committee believed it would be a mistake to abolish corporal punishment. Rather than fear of discipline, reformers encouraged teachers to appeal to the child's natural love or order. "Hereafter corporal punishment shall not be resorted to in any of our public schools either primary or grammar."

Anna Gardner also referred to the move away from corporal punishment. "I have myself for many years been greatly opposed to it; though I should be unwilling to say in advance that it should not be resorted to under any conceivable circumstances." She firmly believed that "among a class of pupils so docile and grateful as those who attend our schools, we shall not probably ever have occasion to resort to it." ${ }^{172}$ Regarding the freedpeople, Gen. O. O. Howard,

${ }^{172}$ Freedmen's Record, vol. 1,no. 12, vol. 2, no. 3. 
head of the Freedmen's Bureau, concluded, "whipping may do for slaves, but the freedmen should do right without it."173 A method that seemed to work more efficiently than corporal punishment, Gardner found, was "the threat of expulsion, to which I used sometimes to resort." She claimed that the threat of expulsion alone "always proved sufficiently potent to insure good conduct."174

Many freedpeople had strong political sentiment that spilled over into other areas of their lives. In Charlottesville, Paul Lewis noted the machinations of some whites as they attempted to woo blacks away from the Republican Party. His letter, published in the Freedmen's Record, parodied the current political rhetoric. "They say 'you must vote for a Southern man;' if we do not, the country will never be right any more." Attempting to endear their former chattel, whites claimed that, "we are your friends; we raised you all, and know what you need best." Lewis wrote to his New England benefactors, "they have never proved their friendship to us yet. We all know who have helped us in time of need."

In Charlottesville politics superseded all else, which one federal Bureau agent noted. "A Lincoln Temperance Society was formed here in June but has not met with much success." Certain that "politics absorb all their attention," the agent believed that "now their religious meetings are detested by many who were once constant attendants." He further explained "nothing but a Union League or a Political Society can command the attention of these people at the present time."

\footnotetext{
${ }^{173}$ Boston School Committee Records, Boston Public Library, December 24, 1864; September 11, December 11, 28, 1866. Jacqueline Jones, Soldiers of Light and Love: Northern Teachers and Georgia Blacks, 1865-1873 (The University of Georgia Press, 1992), p. 125.

${ }_{174}^{74}$ Freedmen's Record, Vol. 3, no. 1, January 1867, p. 7.

${ }^{7 / 5}$ The Freedmen's Record, vol. 3, no. 7, July 1867, pp. 118-19.
} 
Serving as a form of political education, the union leagues "convened in black churches, schools, and homes and also, when necessary in woods and fields." Opening with prayer, followed by the swearing in of new members and pledges "to uphold the Republican party and the principles of equal rights," these meetings took on a religious fervor. Three items occupied a prominent place at the Union League meetings: the Bible, a copy of the Declaration of Independence, and a farming implement. ${ }^{176}$ The agent believed that "after the political excitement subsides, then the temperance cause can be agitated with good excitement." Although he had been charged with organizing a temperance group he conceded that, "in justice to the colored people it would be well to state, that in this County, there is very little habitual intemperance among them and as a class they are temperate."177

The comments of the bureau agent illuminate the freedpeople's political leanings. Just as importantly their activities speaks to a people's desire to define their lives rather than be defined by forces outside of themselves. The things by which they ordered their lives defined who they were. Self-representation, class affiliation and identity were intricately connected as freedpeople carved a new place for themselves in society. Their aspirations to live a full life became a part of their daily enactment of freedom.

The changes went hard on the native whites. Paul Lewis, the former slave, who by now had become a teacher wrote, "It is very strange to the white people

\footnotetext{
${ }^{176}$ Eric Foner, Reconstruction: America's Unfinished Revolution (New York: Harper and Row, 1988), p. 283; Jeffrey Kerr-Ritchie, Freedpeople in the Tobacco South, Virginia, 1860-1900 (Chapel Hill: University of North Carolina Press, 1999), p. 74.

177 Freedmen's Bureau Report, March-May 1867.
} 
here to see a colored man acting as a teacher."178 Although the range of feeling among whites varied most found it difficult to accept blacks in new positions. Nevertheless, blacks determined that they must seize the moment and craft their own future as best they could. Carkin recalled that a "Mr. Cook (colored), of Baltimore, has lectured here two evenings this week, making the duties of the colored people toward their own race his text. He spoke well, and gave them good, sound, practical advice." Seeking guidance from their own people, the freedpeople sought out and patronized those who they believed could help them. "Mr. Cook publishes a paper in Baltimore, called the "True Communicator," which has a large circulation among the colored people here".

Much of the initiative to change southern state constitutional law came from the desires and concerted efforts of freedpeople. During the Constitutional Conventions black politicians played a significant role in establishing universal education as a basic right throughout the South. ${ }^{179}$ Although the population had decreased, the number of illiterate whites had increased. The number of illiterate blacks remained high but fixed. ${ }^{180}$

When Virginia Republicans convened in the African Church in Richmond, more than three thousand black men, women, and children gathered outside, waiting to enter. Their large numbers forced party leaders to move the next day's session to Capitol Square. Richmond's black tobacco workers informed their

\footnotetext{
${ }_{178}$ Paul Lewis, The Freedmen's Record, vol. 3, no. 4. April 1867, p. 59.

179 Leon Litwack, Been in the Storm So Long (Vintage Books, August 1980), pp. 548, 552.

${ }^{180}$ Between 1860 and 1870 , the number of illiterate whites increased from 48,912 to 67,997 . The number of illiterate blacks was 207,505. J. L. Blair Buck, The Development of Public Schools in Virginia (Richmond: State Board of Education, 1952), p. 69.
} 
employers that they intended to stop work in order to attend the proceedings.

The intricate connection between the laboring class and their political representatives underscores a shared value system among blacks. Black delegates articulated the wants and needs of their constituents.

Locally, freedpeople elected men they knew: men who would express their economic and political needs as well as their hopes and dreams. On July 1, 1867, Charlottesville had its first large political meeting initiated by freedmen. Both black and white men had been invited to present their political opinions. The meeting, which drew a large crowd, was held at the Delavan Church.. The three black men who spoke demonstrated the range of political thought among African Americans. Ossian Johnson resided in Charlottesville. He was formerly a slave who had purchased his freedom. Although he could read he could not write. As an officer in the Delavan Church, later called the First African Baptist Church, he was well known and influential among blacks. Johnson recommended supporting whites for political office. Most of the listeners did not favor his position.

Nicholas Rickmond, also a resident of Charlottesville, was a shoemaker who had always been free. In addition to his trade he was a preacher and he could read and write. The freedmen's bureau officer claimed that Rickmond was "intelligent, and exercised considerable influence among the colored people." However, a few months later for some reason Rickmond fell out of favor with many in his congregation. When he rose to lead a hymn, "instantly the whole 
congregation, with the exception of some thirty or forty, rose to their feet and marched out of the church."181

The third black man, Fairfax Taylor, had also purchased his freedom and resided in Charlottesville. He, too, was an officer in the church. Not only could he read and write, he also had some knowledge of grammar, which the other two candidates did not have. "He is respected in the community, but his influence is said to be limited," the agent stated. Taylor contended that blacks should have all the rights and privileges whites enjoyed. He further demanded that blacks should have the right to serve on juries and to attend the University of Virginia. ${ }^{182}$ The majority of blacks favored Taylor's position.

At a subsequent meeting on September 1,1867 , to consider delegates to the Constitutional Convention, one of the blacks in the assembly nominated Taylor's son, James T. S. Taylor, stating: "I want a colored man." Fairfax opposed his son's nomination on the grounds that neither his son nor other blacks, were properly prepared for such a responsibility. Furthermore, the senior Taylor believed it would be detrimental to long-run Negro interests for blacks to hold political office. However, some still insisted on nominating James Taylor; one man asserted, "I want a loyal man, even if he don't know 'B' from a Bull's foot." 183 Race loyalty splintered as Fairfax Taylor announced that he could not support his son's political aspirations. Another man, however, felt he must support James Taylor because of their racial affiliation. The assembly split on the nomination

\footnotetext{
${ }^{181}$ Charlottesville Chronicle, November 12, 1867.

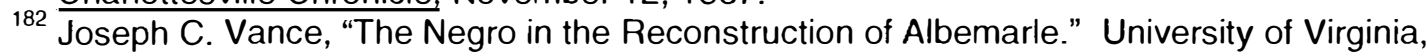
Masters Thesis, 1953. Pp. 18-20.

${ }^{183}$ Charlottesville Chronicle, Oct. 3, 1867.
} 
because some were concerned about the manner in which James Taylor would represent them at the convention. One black man $(H$. C. Harris, from Ohio) said "it would be folly to send a man to the convention who could not properly speak English." Fairfax reinforced his position and nominated instead the prominent and well-known judge, Alexander Rives. ${ }^{184}$

Yet, despite his father's lack of support, Taylor was elected to the Constitutional Convention. He was one of the 24 black representatives at the Underwood Convention. His political ascendancy amplifies intra-racial politics as well as political and generational differences within families. Simultaneously, this incident shows the diversity and fragmentation inherent in an evolving society and to a people in transition. Central to their ideas and discussions about political representation were their ideas about self-representation.

Of the seventy-three Radicals, twenty-four were men of color, nearly onefourth of the entire body of 105 members. Eleven of the 24 black representatives came from the Virginia tobacco region. ${ }^{185}$ Eight of these men had been born into slavery while four others were freeborn. ${ }^{186}$ Six of the men were literate. Only one, James B. Carter of Tennessee, was not a Virginian. Most of the men held no property although William Moseley became a large landholder as did a few others. Their occupations ranged from agriculture to ministerial work.

\footnotetext{
${ }^{184}$ Vance, p. 27.

185 They were James D. Barrett (Fluvanna County), James W. B. Bland (Prince Edward County), David Canada (Halifax County), James B. Carter (Chesterfield and Powhatan Counties), Samuel Kelso (Campbell County), William Moseley (Goochland County), Francis Moss (Buckingham County), Edward Nelson (Charlotte County), John Robinson (Cumberland County), James T. S. Taylor (Albemarle County, and John Watson (Mecklenburg County).

${ }^{186}$ James Barrett (Fluvanna County), James Bland ((Prince Edward County), Francis Moss (Buckingham County), and James T. S. Taylor (Albemarle County) had been born free.
} 
Several of them worked at multiple trades. Only three continued their work in public service. $^{187}$

Between December 1867 and April 1868 the majority of delegates elected the federal judge, John C. Underwood, as their leader and hammered out the details of a new constitution. Underwood had lived in Virginia since the 1850 s, having arrived from New York. After four months the convention delegates had crafted a document that departed significantly from previous practice. The Underwood Constitution of 1868 ratified the Fourteenth Amendment. The Constitution also disfranchised civil and military officers of the Confederacy. The constitution also adopted the township system, a New England pattern, which improved black representation in urban areas. Each township was to be divided into as many districts as were necessary.

In addition the Underwood Constitution established a statewide system of free public schools. ${ }^{188}$ The delegates recommended that there be a (1) a State

\footnotetext{
${ }^{187}$ The convention met from December 3, 1867 until April 16, 1868. Francis Moss (Buckingham County) and William Moseley (Goochland County) served in the Senate from 1869-71 while John Robinson (Cumberland County) served from 1869-73. Moss went on to serve in the House of Delegates from 1874-75. Bland became a federal official. The first historical sketches of black Republicans can be found in Luther Porter Jackson's Negro Office-Holders in Virginia, 18651895, (Norfolk: Guide Quality Press, 1945); also see Alrutheus A. Taylor, The Negro in the Reconstruction of Virginia, (New York: Russell and Russell, 1969, 1926), p. 227; Eric Foner, Freedom's Lawmakers: A Directory of Black Officeholders during Reconstruction, (New York: Oxford University Press, 1993), especially pp. 12-13, 19, 38, 42, , 125, 155-56, 159-60, 185, 209, 225. For photographs see Ibid. pp. 19, 25, 59, 69, 94, 134,169, 217. See also Richard Lowe, "Local Black Leaders During Reconstruction in Virginia," Virginia Magazine of History and Biography, 103 (April 1995), 181-206. For a comparative local perspective see Harold Forsythe's "'But my Friends Are Poor' Ross Hamilton and Freedpeople's Politics in Mecklenburg County, Virginia, 1869-1901" in Virginia Magazine of History and Biography, p.105

(Autumn 1997), pp. 409-38.

${ }_{88}^{8}$ Additionally, the Underwood Constitution replaced viva voce voting with the secret ballot; reduced the residency requirement for governor from twenty to ten years of United States residence and from five to three years of Virginia residence. The Constitution also made land taxes the chief basis of state revenue; issued a $\$ 2,000$ homestead exemption; forbade investments in internal improvements as well as forbidding interest rates in excess of 12 percent.
} 
Superintendent of Public Instruction, elected by the General Assembly, and (2) a

State Board of Education composed of the Governor, the State Superintendent of

Public Instruction, and the Attorney General, with power to appoint and remove

all county superintendents of schools, to manage the school fund and to

supervise the higher grades as later determined by law. ${ }^{189}$

Reverend William H. Ruffner of Lexington, Virginia, became the first State

Superintendent of Public Instruction elected by the Legislature. According to the

new constitution, when the General Assembly elected Ruffner, one of his first

duties was to draw up a plan, which could be enacted into law, for the

establishment and operation of the schools. Ruffner's Report on Schools

included such a plan for the establishment of free public school in Virginia as

required by the Constitution. ${ }^{190}$ He mandated that three school trustees were to

be elected in each school district for one, two, or three years respectively.

See Lynda Morgan, Emancipation in Virginia's Tobacco Belt Black (Athens: University of Georgia Press, 1992, p. 166); Richard L. Hume, "The Membership of the Virginia Constitutional Convention of 1867-68: A Study of the Beginnings of Congressional Reconstruction in the Upper South," Virginia Magazine of History and Biography 86 (October 1978), pp. 461-84; Jack P. Maddox, Jr., The Virginia Conservatives, 1867-1879: A Study in Reconstruction Politics (Chapel Hill: University of North Carolina Press, 1970), pp 57-60; Richard Lowe, Republicans and Reconstruction in Virginia, 1865-1870 (Charlottesville: University of Virginia Press, 1991), pp. 144-46.

${ }^{180}$ Regarding the future compulsory school laws the General Assembly "shall have power after a full introduction of the public free school system, to make such laws as shall not permit parents and guardians to allow their children to grow up in ignorance and vagrancy." The constitution also provided for the support of public education through the interest on the Literary Fund, and all of the capitation tax as had been done before, and then added a state property tax. Local taxation for schools was not compulsory but each county and public school district was authorized to raise additional money by a tax on property. J.L. Buck, The Development of Public Schools in Virginia (Richmond: State Board of Education, 1952), 69.

${ }^{190}$ Many of Ruffner's recommendations, submitted to the General Assembly on 28 March 1870, were incorporated into the school law adopted on11 July 1870. Ruffner believed that particular date to "be an epoch in the history of Virginia." Annual Report of the State Superintendent of Public Instruction, August 31, 1871, p. 4. J. L. Blair Buck, The Development of Public Schools in Virginia (Richmond: State Board of Education, 1952), p. 71. 
Thereafter, one trustee was to be elected or appointed annually. ${ }^{191}$ Although the school board member were all white, NEFAS officials still believed it would be judicious to put "two of the colored men on the Board." From their interactions with Paul Lewis and from what they had leamed from Philena Carkin and Anna Gardner, they believed Lewis was "one of the most intelligent and reliable colored men they had met."192

The New England societies continued to send teachers. At the same time they began to seek alliances with the nascent school boards throughout the South. By the 1868-69 school year NEFAS sponsored twenty-one schools and thirty teachers in Virginia. They estimated that at least fourteen hundred and sixty pupils benefited. ${ }^{193}$ "Our schools in Virginia are about the same as last year" NEFAS officials reported.

Two of Gardner's students were "engaged in teaching." Both "Mrs. Isabella Gibbins (sic) and Paul Lewis" were "among the best of our colored teachers, and are doing themselves and us great credit." Their progress assured the officials

\footnotetext{
191 Three trustees were selected in Albemarle County. Judge Alexander Rives had been admitted to the bar in 1829. Subsequently he became a member of both houses of the legislature, and of Congress, and later he was appointed Judge of the United States Court for the Western District of Virginia. See Albemarle County in Virginia by Reverend Edgar Woods (Charlottesville, Va., 1901), p. 305. John E. Abell was a democrat, and a member of the Board of Supervisors. In addition he was appointed chairman of the board of supervisors for Albemarle County. See History of Virginia (American Historical Society: Chicago and New York, 1924), volume 4, p. 324. Nathaniel C. McGhee, also served on the school board. He became a board member at the Miller School in 1885 and in 1904 he was elected treasurer of the county. See $\underline{A}$ Memorial History of the John Bowie Strange Camp of the United Confederate Veterans, edited by Homer Richey (Charlottesville: Michie Co., 1920). Thanks to Frances Pollard at the Virginia Historical Society and Margaret O'Brien at the Albemarle County Historical Society for tracking down this information.

${ }_{192}^{192}$ NEFAS Records, September 29, 1869.

${ }^{193}$ The Freedmen's Record, v. 5, no. 2, June 1869. South Carolina counted twenty-six schools, forty-two teachers, and two thousand and seven hundred and forty pupils. Throughout the South NEFAS sponsored 104 teachers, 58 schools, and 6,490 pupils during the 1868-' 69 school year.
} 
that their work must go on. "The bureau is about to build them a schoolhouse."

The dilapidated condition of the school prompted officials to report that it was "absolutely necessary to rebuild it." They believed that "there is now a fair prospect of having a school house during the summer."194

The officials wrote to Ralza Manly who had been appointed by the Freedmen's Bureau in 1865 to coordinate the activities of various philanthropic organizations in Richmond. He also worked to establish a uniform system of education for the freedpeople. In addition to being the first principal of the Negro Normal and High School of Richmond, Manly was also involved in city politics as a city school board member and a member of the council in Jackson Ward. ${ }^{195}$ The officials also wrote to Anna Gardner "asking for a few facts, in case we should wish to make an application for aid to the Bureau to establish a Normal School in Charlottesville."196

Recognizing a need to prepare for the future withdrawal of their teachers, NEFAS officials wrote, "We have for some time had the establishment of a normal school at Charlottesville in anticipation regarding that locality as a prominent center of influence." NEFAS officials asked Manly for his opinion about the "prosperity and expediency of establishing a Normal School at Charlottesville."197 Acting quickly, the officials also wrote to General Brown, informing him that "we learn indirectly that some movements are in progress to

\footnotetext{
${ }_{195}^{194}$ The Freedmen's Record, v. 5, no. 3, August 1869.

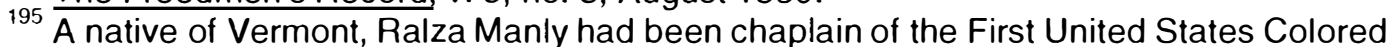
Cavalry, a black regiment in the Union Army. Michael Chesson, Richmond After the War (Richmond: Virginia State Library, 1984), 100.

${ }_{96}$ NEFAS, Daily Records, March 25, 1868.

${ }^{197}$ NEFAS, Daily Records, March 25, 1868.
} 
establish denominational schools at Charlottesville, and the aid of the Bureau will be solicited." They hoped to maintain a close working relationship with the Bureau and began to petition for continued help. The NEFAS officials hoped for the bureau's "continued interest in the school of our society, which recognize no distinctions of caste or creed."198

Toward the end of the school, year Anna Gardner informed the committee that she needed to "know something more definite respecting the Society's plans, in order to be able to raise money among the colored people." She believed that "enough money could be raised to buy land if all the scholars are to continue to receive instruction, but not if it is to be limited to only the 30 or 40 in her class, as a Normal school."199 Making their desires known, the freedpeople preferred a democratic institution that would educate as many as possible rather than a few who would then go forth and teach others. The freedpeople's ideas for a school were quite different from the ideas and plans of their benefactors. ${ }^{200}$

NEFAS officials pursued the construction of a normal school. "It is very important to educate a portion of the colored people in a high degree, as leaders of the rest." The locality fostered a strong sense of success that encouraged the officials to build an institution of higher learning. "Charlottesville, although not a large city, is important from its literary celebrity, because whatever is done there will come under the observation of the most cultivated people of Virginia." Commenting on the freedpeople's potential for success, NEFAS officials decided

\footnotetext{
${ }^{198}$ NEFAS, Daily Records, April 1, 1868.

${ }^{199}$ NEFAS, Daily Records, May 6, 1868.

${ }^{200}$ NEFAS, Daily Records, June 18, 1869.
} 
to invest a considerable effort in Charlottesville. When the chairperson of the teacher's committee, Ednah Cheney, toured the Southern schools she "heard less of the faults of enunciation peculiar to the Southern negro here, than in any other Virginia school." In particular, she mentioned Isabella Gibbons, who "has a better faculty of governing her school than most of the Southern teachers, with whom discipline is apt to be the weak point." Although Gibbons had recently entered the teaching field, officials claimed "It requires long training and culture to acquire the art of governing others." In talking with some of the students Cheney learned that "the young men and women of Charlottesville also very much desire a library and reading-room."201

When Cheny returned to Boston and submitted her report, the officials wrote a letter to Ralza Manly expressing their hope "in securing a proper, permanent school building for Charlottesville; which seems to us a very desirable place to establish a good Normal School." They were concerned after Cheney reported that the barracks where students and teachers gathered for school was a "leaky, smoky, and unsafe" building. They believed that the "influence of such a crazy old building" could have deleterious effects upon its occupants. "Our hearts are in a new school house for Charlottesville, where there is better material than almost any other place for a Normal class." In addition, the officials wanted the school to "be sustained by us, if possible, as long as we see need of its continuance." Their goal was to "work in the direction of preparing good teachers even after a public school system relieves us of the rest of our present work in

${ }^{201}$ Freedmen's Record, V. 4, no. 12 Dec 1868 
Virginia." The town of Charlottesville, the officials enthused, "seems a specially good location for such a Normal school."

After investigating the possibility of a school house, Manly determined that "the cost will not fall much below $\$ 1700$." Promising $\$ 600$ NEFAS officials managed to secure a promise of an additional $\$ 600$ from the Freedmen's Bureau. The remainder would come from the freedpeople. ${ }^{202}$

The outward signs of change occurred slowly. In large part stasis was due to the financial difficulties that everyone endured. Gardner described the conditions under which she labored. "We have only benches (without backs, mostly) and chairs which they bring from home. A few of the other scholars have furnished themselves with desks, and we have some rough tables which the soldiers left." ${ }^{203}$ Not long after this, however, Gardner noted, "desks are now being made with money furnished by the sale of Government property. We have had three meetings of the Charlottesville Branch Society." As an auxiliary to the New England Freedmen's Aid Society, the freedpersons had pooled their resources. "Eighty dollars is the amount which has been contributed for the schools here during the last three months." Gardner posited that "perhaps they may do better when matters pertaining to their political condition become a little more settled."204

At the federal level legislative changes signaled a new era. On March 2, 1867, the Military Reconstruction Act declared that among the ten seceded states no

\footnotetext{
202 NEFAS, Daily Records, June 18, 1869.

${ }^{203}$ Freedmen's Record, v. 4, no. 2, February 1868.

204 The Freedmen's Record, v. 4, no. 3, 1868.
} 
legal state governments existed. The act also divided the South into five military districts. Each district was under the control of a small contingent of troops. The district generals prepared the states under their rule for readmission to the Union.

Throughout the South, bureau agents had been charged with gathering black and white men who were considered leaders in their communities. On March 12, 1867, the Bureau agent in Charlottesville responded. He had identified nine whites and nine blacks. He admitted, however, that he was "not personally acquainted with all these men, but am informed that they are, without exception, respectable and worthy gentlemen."205

Gardner noted distinctions among the blacks she encountered. She recalled a conversation with one freedman who demonstrated an intellectual consciousness that surprised Gardner. "An old colored man of this place said to me, 'Friends are good things, but they are very slippery; there is no better friend than your money'." Gardner said he placed his hand on his pocket and referred to his money, "call upon it, and it will surely respond 'here am I'." Gardner acknowledged the lesson she learned from listening to "this old man (Tom Farrar he is called)," who "was a free negro, and amassed considerable property. He is truly "an original." It would be impossible to keep such a mind from developing intellect in some directions, but I never talk with him without thinking what a crude, restrained, unnatural development was his, under the crushing, degrading influence of slavery." As she learned more about southern culture, she also learned more about herself. "For the free colored man suffered almost as much

\footnotetext{
${ }^{205}$ See Appendix for a copy of the Bureau Agents Report.
} 
as the slave; much more than I supposed before coming to the South." ${ }^{206}$

Knowledge opened the eyes of teachers and students as they interacted in new and different ways.

The freedpeople's dire straits did not hinder them from making contributions toward their education; they willingly gave money in support of the schools. Philena Carkin referred to the fundraising efforts of the freedpeople in her letter of May 20. "They are preparing for an exhibition, the proceeds of which are to go towards fundraising land for the schoolhouse." She had asked Ralza Manly to "address the people on the subject." She and Gardner believed that "a lot of land will probably cost $\$ 200$ or more." Carkin’s letter, printed in the Freedmen's Record, highlights the faith she had in the freedpeople as well as their determination to shoulder the responsibility of educating themselves. "Miss $\mathrm{C}$. anticipates no difficulty in raising the money, as the people there give liberally toward the support of the schools." 207

In 1870, nearly one-fourth of the school-aged ex-slaves throughout the South attended "public" schools. The freedmen's initiative in starting schools and their attendance rates made it evident that "free" schooling was becoming a customary right in the postwar South. Bureau reports show uneven school attendance throughout the South. Yet, steady attendance in enough places signaled a fundamental shift in southern tradition. ${ }^{208}$ In Virginia, 2,900 schools had opened during the 1870-71 school year. The 1,400 district trustees served

\footnotetext{
${ }^{206}$ NEFAS, Daily Records, v. 4, no. 11, Nov. 1868.

207 NEFAS Daily Records, May 20, 1868.

208 James D. Anderson, The Education of Blacks in the South, 1860-1935 (The University of North Carolina Press, 1988), p. 19.
} 
3,000 teachers and 130,000 students. ${ }^{209}$ Gen. O. O. Howard increased a grant for the schoolhouse to $\$ 800$. In addition to various other sources, officials felt that enough funds were raised to "build a school house which will have all that is absolutely essential to the comfort and convenience of both teachers and scholars." 210

NEFAS officials recognized the need to continue financial support. In order to accomplish their larger mission "the normal schools will need our aid for some time to come. These schools will be necessary to educate a body of teachers to take charge of the schools, to serve as models and as stimulus for other schools, and to furnish a higher education to those who are fitted for it." They cited "Charlottesville, Richmond, and Baltimore," as three strongholds of educational reform. As proof of their success they noted their former students who had now become "engaged in teaching." They decided to continue fundraising even though they found it "harder to raise money than heretofore." NEFAS was determined that the tight economic times would not stop their quest to acquire "books and libraries" for their charges. ${ }^{211}$ The school in Charlottesville held such hope. For many of the members of NEFAS their dream of equality through literacy seemed to be coming to fruition.

NEFAS officials had raised $\$ 300.00$, half of the amount they had initially planned to raise. "We have done more than for any other place" they claimed, giving Anna Gardner permission to advance their plans to build a school house.

\footnotetext{
209 J. L. Blair Buck, The Development of Public Schools in Virginia (Richmond: State Board of Education, 1952), p. 69-70.

${ }^{210}$ Daily Records, Massachusetts Historical Society, July 7, 1869.

211 The Freedmen's Record, V. 5, no. 4. November 1869.
} 
"With $\$ 800$ from Bureau, 300 from us, 300 from land and 200 from your people, you are justified in going to work." They also admonished Gardner to steer away from the business of building a school. "Making a contract isn't an easy task. Don't you get yourself involved in it." Anna Gardner had reached a new level in her professional development. In a sense she had inverted the student-teacher dynamic. Her work for the freedmen gave her a new perspective in which to be. She became a student, learning beyond her position as teacher of the freedpeople.

Nonetheless Gardner felt compelled to remain in Charlottesville if "the building is to come down." Gardner informed the committee that the carpenter had brought a plan for her to see" but it was too expensive. He will bring in another not exceeding \$1000." Gardner had looked at the plans for the building and thought "the plan too contracted." When the committee reviewed the plan they suggested that it be "lengthened at each end about six feet if it cost no more than $\$ 150.00$." They believed they could raise the necessary funds but they cautioned Gardner "to say nothing about it to the people as it is desirable they should raise as much as possible." ${ }^{212}$ By July Gardner could report that the freedpeople raised "nearly a hundred dollars towards the building." In the meantime, Gardner put her energy toward persuading "the two Scotts and Mr. Abell to give $\$ 20$ each." Their contributions brought the total amount on hand to $\$ 200.00$. $^{213}$

\footnotetext{
${ }^{212}$ New England Freedmen's Aid Society Papers, Massachusetts Historical Society, Daily Records, July 14, 1869, p. 282.

${ }^{213}$ Daily Record, Massachusetts Historical Society, July 2, 1869.
} 
After the dedication of the new Charlottesville school building in September 1869 officials reported, "The school is full." 214 Gardner's textured description of the interior space could perhaps be a model for freedmen's schools throughout the South. "The room of the Jefferson School, about twenty five feet square, is quite an attractive place. The rough but neatly whitewashed boards which constitute its walls are ornamented with evergreens, and illustrated by new and highly colored maps, which together with vases of flowers, replenished every day by fresh bouquets, give the room a gay and cheerful aspect. Printed over three blackboards opposite the teacher's desk is the motto, 'try, try again!' and, as a still further incentive to mental effort, the familiar maxim, 'knowledge is power' is posted on every side of the school-room."215

Despite the progress made by students, both students and their teachers feared that the freedpeople would "be driven back by stern necessity into the same menial employment which they left as slaves." Economically unable to continue his education, Robert Scott "sought employment in town." Nowhere in Charlottesville or the surrounding area could he find a position befitting his new status as an educated person. Scott found himself in a submissive position. If he chose to remain in Charlottesville he had to be a "hewer of wood or drawer of water," Carkin fumed. "The unrepentent rebels are determined that their citadel of power shall never be invaded or endangered by letting down the bars to those

${ }^{214}$ The Freedmen's Record, vol. 5, no. 4., November 1869.

${ }^{215}$ The Freedmen's Record, vol. 5, no. 4, November 1869. 
colored youths who have been educated." Consequently, those with the most education received the most opposition to economic advancements. ${ }^{216}$

Carkin firmly believed that the rebels would "be particularly careful not to open a wider range to the graduates of these Normal classes." Still, 207 students, 36 of whom attended the normal class, enrolled in school. Carkin reported that eight or ten have "been with me over four years." Several were "sufficiently matured to teach" she proudly proclaimed. ${ }^{217}$ Lacking employment, "Robert Scott has returned to school to remain awhile."

NEFAS committee members recognized the possible feelings of discouragement the newly educated freedpeople were enduring. They decided to ask the Massachusetts secretary of the Board of Education if some of the pupils from the schools could be admitted to Massachusetts State Normal Schools, recommending also that the tuition be waived in exchange for a pledge to teach in Massachusetts. ${ }^{218}$

"Not a little discouraged at the aspect of the political horizon, they seem to hoard every crumb of knowledge as though they had a foreboding that their golden opportunities, which they have never been slow to appreciate, were slipping from their grasp. They clutch, seemingly with a desperate effort, at every straw, to prevent themselves from being taken in and borne back on the fast receding waves of national progress." Seeing themselves outside of their past experiences, the students' self-perception changed. At the close of the 1866

${ }^{216}$ The Freedmen's Record, vol. 5, no. 5, February 1870.

217 The Freedmen's Record, v. 5, no. 5, February 1870.

${ }^{218}$ Massachusetts Historical Society, NEFAS papers, Daily Record, July 16, 1869, p. 284. 
school year Celia Rosena Wood looked out of the window where she sat in

school and captured an indelible vision of the power of place. "From our school room we have a beautiful view of the Blue Ridge Mountains. Just opposite where I sit in school, I have a fine view of Monticello Mountain, where Mr. Jefferson lived." ${ }^{219}$ Seated in her schoolroom and in the "shadow of the little mountain," little Miss Celia learned what it meant to be free. Acknowledging her God-given right to freedom (and from obligation to her former mistress), Celia asserted a new sense of self. "Whenever I think of how they treated me, it makes me feel as if it is not my duty to be sorry." ${ }^{220}$ She was free now and she had chosen to explore the world of the intellect.

${ }^{219}$ Celia Wood, The Freedmen's Record, vol. 2, no. 7, July 1866, p. 131.

${ }^{220}$ Celia Wood, The Freedmen's Record, vol. 2, no. 7, July 1866, p. 131. 


\section{Part II: Introduction to the Papers of Philena Carkin}

The following section includes twenty-four extant letters from Philena Carkin as well as her memoir. The letters were written to her sponsors in Boston, the New England Freedmen's Aid Society, between 1873 and 1875. These last years of Carkin's stay in Charlottesville held many challenges which her letters describe. The new public school system had begun in 1870, yet in 1873 Southerners, both white and black, still resisted implementation. Tensions mounted between the New England teachers and their African American counterparts as well as the parents and students regarding graded schools, religious differences, and school board involvement. In addition, the letters and memoir offer glimpses into the personal lives of teachers and to some extent, the students.

During Philena Carkin's last years in Charlottesville she noted the passage of time, as well as her contributions. Her contemplative statement summarizes her feelings as her tenure ends. "I cannot help a feeling of sadness when I think that I shall soon leave this scene, and these scholars, some of whom have grown from little children to young men and women in my school, but I shall always have the satisfaction of knowing, there has been great improvement since I came here nine years ago, and I trust that the colored people will yet make a bright mark in our future history." 221 In a subsequent letter Carkin noted changes in the social landscape. Her own obsolescence is also a part of the new order. "A few weeks will terminate my long stay in this place and I have my hours of sadness

${ }^{221}$ NEFAS Records, Massachusetts Historical Society, April 4, 1875 
and my hours of retrospection also, and when I look back over the nine yeas I have been here, I can hardly persuade myself that this is the same place." Recalling her early experience when she "used often to write two, three, and four letters per day for the colored people," Carkin accepted the fact that "now I am never called upon, as there is scarcely a family in which they have not some one who can wield the pen." Where once freedpeople had crowded into town finding shelter wherever possible Carkin claimed she could now "count dozens of neat cottages (in sight of my window) built and owned by colored men." Admittedly there was still "much to discourage and sadden." Yet, Carkin stated with confidence that "with the colored people I feel that the south must rise or fall."222 Carkin returned to the northeast at the end of June in 1875

${ }^{222}$ NEFAS Records, Massachusetts Historical Society, June 4, 1875. 


\section{Editorial Note:}

Carkin's memoir, written in the first few years of the twentieth century, and culled from her Reconstruction-era diaries, add another layer of cultural commentary. As much as possible I have kept editorial intrusions to a minimum. Where necessary brackets are used. For example, where words could not be deciphered brackets denote such: [unclear]. In addition, when words were misspelled in the text, they remain as written followed by (sic).

Several studies guided me. They are: Editing Historical Documents: A Handbook of Practice by Michael E. Stevens and Steven B. Burg; Tombee: Portrait of a Cotton Planter by Theodore Rosengarten (1986); The Journal of Charlotte L. Forten, edited by Ray Allen Billington ( 1953); The Private Mary Chesnut edited by C. Vann Woodward and Elisabeth Muhlenfeld (1984); and $\underline{A}$ Northern Woman in the Plantation South edited by Wilma King (1993). 


\section{The Edited Letters of Philena Carkin}

My Dear Mrs. Cheney, 223

Tyngsboro Sept $21 \mathrm{st} / 73$

I write chiefly to forward the enclosed letter from Mrs. Lewis 224 which came to hand a day or so after I was with the Committee in Studio Building. 225 The

Mr. Scott referred to in the first part of the letter is a teacher from Washington and the husband of the Mrs. Scott who has taught in C. for the last two years. The last Mr. Scott, (the one who has been making repairs) is Mr. Robert Scott. 226 The letter has caused me considerable annoyance as I charged Mr. \& Mrs. Lewis not to have our rooms opened for any purpose during our absence, and I knew that you had also written them that they were to remain undisturbed. They were not in need of any repairs of the kind mentioned and I have every reason to think that all they have done will cause more discomfort than otherwise.

223Ednah Dow Littlehale Cheney, a Boston native and resident, had been actively involved in reform work for many years. She first became involved through the antislavery cause. She came from a modest background, her father was a partner in a grocery business, and her maternal grandfather had been a tanner. She married an artist, Seth Cheney, who died within three years of their marriage. They had one daughter, Margaret. Ednah Cheney's interests were broad. She assisted in founding the Boston School of Design for Women, the New England Hospital for Women and Children, the New England Woman's Club, and a Horticultural School for Women. As a member of the Executive Committee and the Committee on Teachers in the New England Freedmen's Aid Society, she corresponded with the teachers regularly and investigated the schools of the South on a number of occasions. Regarding investigations of Southern black schools, see pages 85-98 of Ednah Dow Cheney's, Reminiscences of Ednah Dow Cheney (Boston, 1902).

${ }^{224}$ In the 1870 Census Paul Lewis (age 37) listed himself as a teacher and his wife, Margaret (age 25), classified herself as a housekeeper; they valued their real estate at $\$ 600$. All but their youngest child attended school: Augusta (11), Pleasant (9), Lewisa (6) and Pearl (3). Another child, Eliza Clarkson (12) lived with them and attended school also 1870 United States Census-Virginia, T8-410, Albemarle County, St. Anne's Parish, p. 155). Lewis, a black man and native of Virginia, had been working as a teacher as early as 1868; he named his primary school of students the John Brown School (Records of the Bureau of Refugees, Freedmen, and Abandoned Lands, School Reports, File 692).

${ }^{225}$ Studio Building refers to the headquarters of the New England Freedmen's Aid Society in Boston, Massachusetts. The organization occupied room number eight in the Studio Building on Tremont Street. ${ }^{226}$ The Scotts were a family in Charlottesville well-known for their musical talent. 
Our beds, bedclothing, some of our wearing apparel, crockery etc. etc. were put in those rooms for safekeeping, and the idea of Paul Lewis searching for our keys and opening the rooms for workmen to enter, against my express desire is particularly annoying. Besides that, I feel inclined to think that Mr. Scott will call upon Mr. McGhee to advance money to pay for the work. In that case, I should be left entirely without funds to commence my school with. 227

As the members of the Committee who were present last Wednesday told me explicitly that they wished the rent for the rooms to be paid into my hands as heretofore, and knowing that three or four days delay might make a great difference (and it would have delayed a week if I had waited to consult you) I took the liberty to write to Dr. McGhee, and tell him just what was told me at Studio Building so that he might understand that Mr. Scott had no authority to call upon him for funds, and requested him to retain the rent money in his own hands until my arrival and also advising him to consult with you upon any point not made quite clear. 228 I also wrote to Mrs. Lewis and told her how annoyed I was that Paul should take such a liberty etc. The repairs they made were such as could have been postponed until I had come to superintend. Knowing the people as I do, Mr. Scott particularly, I am positive that the work will be done in a most unsatisfactory manner. I had written and engaged the carpenter to put the support under my room and as they did the same kind of work last year, I felt it would be done satisfactorily. I may be in error in regard to the manner in which Mr. Scott intends to pay for the work. He may have arranged to pay from a

\footnotetext{
227 Nathaniel C. McGhee was born in 1836 and died in 1919. He made his home in Ivy, outside of Charlottesville. In addition to serving on the new public school board he was also chairman of the board of supervisors for Albemarle County, treasurer of the county and he sat on the board of the Miller School. ${ }^{228}$ Carkin probably is referring to the Committee on Teachers, of which there were eight members: Rev. John Parkman, Loring Lothrop, Miss H. E. Stevenson, Mrs. Ednah D. Cheney, Rev. Charles Lowe, Mrs. J. A. Lane, Rev. W. Hague, D. D., and Miss M..J. Ellis (Freedmen's Record, December 1865, p. 204).
} 
portion of the money due for the land, but I have seen so much of his management - that I would not trust him with any power whatever, as he would be sure to exceed any authority delegated to him. I long to get started for $\mathrm{C}$. in order that I may as Mrs. Lewis says "Set things to right."

I haven't written this letter to annoy you, but I felt it right that you should know how Mr. L. would carry out your suggestions. I shall act upon your advice when I reach Charlottesville and endeavor to obtain an interview with Judge Rives. ${ }^{229}$ । feel sure that matters can be made pleasant, or comparatively so, if there is some one to appeal to of whom Mr. Scott will stand in awe. But he likes to hold the reins, and be acknowledged as an authority, in matters where his judgment may well be called in question. I hope that a few days will smooth out matters when I reach there, and I have no doubt my school may prove very pleasant indeed. The school has always been pleasant, except when its harmony has been disturbed by outside interference.

Miss Crocker suggested a small work on Philosophy for my use. 230 I think she said by Quackenboss, but there have been so many different works recommended that there is a confusion in my mind in regard to them. 231

With kind regards, I am as ever sincerely yours

\section{Philena Carkin}

\footnotetext{
${ }^{229}$ Judge Alexander Rives, the son of Robert and Magaret Cabell Rives, was admitted to the bar in 1829. He became a member of both houses of the Legislature and of Congress; he was later appointed Judge of the United States Court for the Western District of Virginia. He died in 1885 (Rev. Edgar Woods, Albemarle County in Virginia [Charlottesville, Va., 1901], 305).

230 Lucretia Crocker served on several boards related to women's causes in New England.

${ }^{231}$ George Payne Quackenbos (1826-1881) wrote several textbooks all published by D. A. Appleton in New York. He began in 1858 with an illustrated school history book and continued writing through 1872, finishing with an arithmetic book. He also wrote on grammar, rhetoric and composition.
} 
My Dear Mrs. Cheney,

Charlottesville Oct 12th/73

I have deferred writing to you until I could be able to tell you just how matters stand here.

Heretofore, everything has been so unsettled that it would have been impossible to have given you a satisfactory idea of the state of affairs, but now I feel that we have arrived at a point where I can stop and review matters a little.

On our arrival here I was happy to find matters in a better condition than I had feared they might be. The house had been whitewashed and certainly looks much more respectable than it did before. The support had been put under my schoolroom in accordance with my orders to Mr. Lewis. Our private property had been so well cared for by Margaret that nothing was disturbed or injured. What was better than all, Mr. Scott had made arrangement with the workman he engaged to wait for his pay until he could get some money Mr. Moses had promised him. So my apprehensions on that score were quieted. While Miss $\mathrm{H}$ was here, we had a great many callers, all of whom seemed earnest in regretting her removal. 232

On our arrival we found Mr. Scott (of whom I wrote to you in a former letter) teaching in the school-room formerly occupied by Miss $\mathrm{H}$. Rumors from different sources reached our ears that he had declared his intention of not acting in connection with the other schools in the building - had even forbidden his pupils playing with the other scholars here, but told them they must go over to the church and play with Mrs. Scott's scholars. Both he and Mrs. Scott set themselves in direct opposition to me in every possible way. I sent a note to Dr. McGhee containing the bill for the rent of the rooms, and expressing a desire to

${ }^{232}$ Miss Holmes was also a NEFAS teacher, possibly from Concord, Massachusetts. 
see him at his earliest convenience. He answered promptly in person, and I

stated to him the desire of the committee that the school should continue as one, as heretofore etc. etc. He said there would be no difficulty in the matter for although he had written for Mr. \& Mrs. Scott to take the school, when he learned that it was decided I should return he had told them that of course I was to hold my position as Principal. I made several little suggestions to him in regard to such matters as keeping the rooms clean etc. and asked if he would mention it to his teachers and he promised to do so. He went immediately into Mr. Scott's room and remained there a long time in consultation with him. Presently he returned, and asked to see me again. I could see at once that he was annoyed. He told me that in talking with Mr. Scott he found that he (Mr. S.) had somehow got the idea that his school was to be a separate affair altogether and that he was very much opposed to having pupils graded from his room into mine etc. The Dr. then proposed to have a meeting of the teachers and Board that P. M. with Mr. Powers the county superintendent. 233 Before the meeting Mr. Powers, Dr. McGhee, and Mr. Long (chairman of the board) subjected Mr. Scott to an examination, as Mr. Powers (the one on whom that duty devolves) lives at Scottsville, a distance of about twenty miles, and had not seen him before. As he, Mr. S. was a student in Howard University they had felt no hesitation in allowing him to open school prior to examination not having the slightest doubt of his competency. 234 Upon examination however, he was found deficient in the

\footnotetext{
${ }^{233}$ David Pinckney Powers became Albemarle County's first Superintendent of Schools in 1870. He held the position until 1882, when L.A. Michie, was appointed. When Michie retired in 1886, Powers again assumed the title and kept it until his death in 1894. See John Hammond Moore, Albemarle: Jefferson's County, 1727-1976 (Charlottesville, 1976), 234-35, 269, 323.

${ }^{234}$ Named for Gen. Oliver 0 . Howard who headed the Freedmen's Bureau, the institution became known as "the capstone of Negro education." Howard University opened in Washington, D.C., on May 1, 1867, under the auspices of the Freedmen's Bureau. (Alton Hornsby, Jr., Chronology of African-American History: Significant Events and People from 1619 to the Present [Detroit, 1991], 40).
} 
very branches, he would have to teach in the room he occupied. After examining Mr. Scott, Dr. McGhee, Mr. Long, and Mr. Powers, came to my room, and Dr. M. requested me to repeat before the other gentlemen what I had told him in regard to the wishes of the Society etc. I did so, and gave them a full understanding of your idea of what you wished the school to be. They asked particularly if I taught Algebra. I told them what you had said to me in regard to that very branch. They all coincided heartily with your views, and Mr. Powers remarked that, in his opinion, that was just where they failed in Howard University--the pupils were put into the higher branches to the neglect of that which was more important. They all expressed themselves in favor or your plans, and were particularly pleased with the idea that I should have a class of pupils of lower grade for my more advanced pupils to instruct.

They then sent for the other teachers to come in-Mr. Lewis Mrs. Gibbons and Mr. \& Mrs. Scott. Dr. McGhee then proceeded to tell them that they wished to carry out the plans of the founders of the school and make it a regularly graded school, all the teachers working as one. "The highest department" he said "should be taught by Miss Carkin. There was to be no question about that." He then proceeded to say that Mrs. Scott should take the second. Mr. Scott, the third, Mrs. Gibbons, the fourth, and Mr. Lewis, the beginners. After he had stated the plan he asked if the teachers had any arrangements to make etc. Mr. Scott then said that all he had to say was that he and Mrs. Scott should resign. They tried to reason with him-and told him that his salary was not to be affected by the position they assigned him. He was obstinate, and they asked him if he was not convinced that he was not qualified for a higher position. He told them decidedly that he was not convinced. They told him that the place they gave him was the best for his own improvement, but all they could say would not do -- it 
must be the first for himself and Mrs. S., or nothing. They told him if that was his decision they must supply their places. And so the matter was left. I dispatched a note to Robert Scott and asked him to apply for the position which he was only too glad to do, as his father likes him at home. The Board waited a few days for Mr. \& Mrs. S. to change their minds and then gave the school to Robert, and I suppose he will open tomorrow and then we shall come together and grade them properly. You do not know how much I am pleased that everything has terminated so satisfactorily. It is so much more than I dared to hope for. I feel that I can look for real assistance from Robert Scott. But from Mr. \& Mrs. S. I could expect only opposition. Another pupil of Miss Gardner's, Egbert Gerry, will take the other department so I see no reason for any discord whatever, now the discordant elements have taken themselves away. 235 Mrs. Scott has always been a stumbling-block in our path ever since she came. She came in a wrong spirit, and she has cherished a wrong spirit all through.

Mr. Long, Dr. McGhee, and Mr. Powers certainly gave them no reason to complain of ill-treatment, for they were courteous and temperate in all they said, but firm. It was more than I expected of them. I feared their anxiety to retain Mrs. Scott would result in some compromise detrimental to the school - but they told Mr. Scott explicitly that they could not consider individuals, they must look to

\footnotetext{
${ }^{235}$ In 1889 Robert Scott was still communicating with the former sponsor, NEFAS. "We are now in the midst of a heated campaign and if we can only get a fair count I believe the Republican ticket will win, but there is the rub. The election machinery is all in the hands of the democrats and they will endeavor to work it to their advantage. Our party is better organized than ever before and a fall vote will be polled. The color question is fully and unmistakably drawn by the democracy and the only issue with it is White man's government and white men against the Nigger." Although interested he could not participate as he had done earlier, citing "poor health." He had hoped a "rest of three months" would enable him to, "continue my work teaching." Having seen "every physician who attributed his complaint to working in a poorly ventilated schoolroom" he now found himself with serious throat trouble. Scott had also conferred with doctors in Richmond and Philadelphia and had "taken a great deal of Medicine." His condition remained the same. Realizing after a month of teaching that he needed to relinquish his position, he also decided to relocate to "some hospital North" because "specialists cannot very well treat me at a distance." See Boston Public Library, Manuscript A.1131, Robert Scott to NEFAS, October 14, 1889.
} 
the good of the school. I must say that I feel encouraged-that they have shown interest in the school that I did not expect, and I hope that their experience is as much advantage to them, as to others. In regard to the money due for rent, the panic makes matters a little awkward for us, as the Bank where the Public Fund is deposited does not cash orders above $\$ 15.00$ in amount. 236 Dr. McGhee has paid that sum, and says that the treasurer says that he thinks he will be able to get the rest in a few days. I have now given you a full account of what has taken place here, and I think there is nothing new to prevent success. At any rate I am hopeful and very much encouraged. I think the colored people seem to appreciate the thought of the school more, they came so near losing it. I shall need some blanks to make out my reports as I have none on hand. Hopefully, and sincerely yours,

\section{Philena Carkin}

\section{Charlottesville Nov 1st/73}

My Dear Mrs. Cheney,

I hope you did not fail to receive the letter I wrote on the 12th Oct. as that contained a full account of our opening etc.

We are getting on finely in our school now--are all full, and I have a large number of my old advanced pupils, some of whom were engaged in teaching last

\footnotetext{
236"The Panic of 1873" was a result of low prices and tight credit. The Funding Act of 1871 had given precedence over payment of the war debt rather than allocations for roads, schools, and public services. One of the leading private investment banks, Jay Cooke and Company, failed on September 18, 1873; the failure was felt across the nation. See James T. Moore Two Paths to the New South: Funders, Readjusters and the Virginia Department, 1870-1883. (Lexington, KY, 1974), 83-92. After the war there were four banks in Charlottesville: Farmers and Merchants, Citizens National, Charlottesville National, and Virginia Loan and Trust Company. Due to the downturn of economic conditions in 1873, all four of them had closed by 1877 (Moore, Albemarle, 263).
} 
year. You will perceive by the enclosed report that I have two beginners. They are little girls, who were unable to get into the other schools owing to their crowded state, and I took them into my room, and gave them into the charge of Mary Ann Tinsley, a girl only thirteen years of age, but a remarkably apt pupil and one of the best of girls. She takes the whole charge of their studies. My first class in Geography recites to Miss Nancy Brown, a young lady well qualified to give instruction in that branch. 237 The second division is taught by Master Burnley Watkins - one of my most thorough scholars. 238 David Smith and John Brown each teach classes in grammar, and William Jackson and Joseph Sellers teach Arithmetic. 239 Harriet Waynes, my oldest pupil teaches a class in reading and spelling, and a fine teacher she is in that branch. I have just as much work as I can possibly do, with all the assistance rendered me by the pupils. I listen to the lessons recited to the pupils, and admire them in regard to methods of instruction as much as possible, and their scholars are doing very well.

The school-board have paid up all arrears, and I have had the house made as comfortable as possible with the proceeds. The scholars in my department pay a tax of ten cents per month to pay one pupil to make fires, keep the halls clean, and take charge of the wood-house. The rent money not being sufficient, after the repair bills were paid, and my own ten dollars taken out. My own domestic

\footnotetext{
${ }^{237}$ Seventeen-year-old Nancy Brown, a black Virginian, listed her occupation as washing(woman) in the 1870 census. p. 153.

238 Not only did Burnley attend school, his older sister, Florence, also attended school. According to the 1870 Census (p. 91), their parents, Martha (45) and Pleasant (65) worked as housekeeper and domestic servant, respectively. The black couple chose to forego the additional household income their children could have brought in so that Florence and Burnley could receive an education. At the time Burnley was ten years old and Florence was fifteen years old.).

${ }^{239}$ John Brown's parents, sixty-year-old Wilson, a farmhand, and fifty-six year old Eliza, a housekeeper, valued their real estate at $\$ 1,000$. Although the black couple had three other offspring, Martha (20), Mannie (11), and Harry (8), seventeen-year old John was the only one to attend school in 1870. (1870 Census, p. 88). Mary Ann Tinsley, David Smith, William Jackson, Joseph Sellers, and Harriet Waynes have not been identified.
} 
matters are much better arranged than ever before, and I think that Margaret

tries very hard to have every thing done right. 240 I think the fear that the society were going to give up the school had the effect of making the people appreciate it more. Now that Robert Scott is in charge of the school next to mine, I feel that I have a hearty co-worker, but if Mr. Scott from Howard University had stayed, I should have looked for no aid nor sympathy from him. I mentioned in my former letter that I had no blanks for reports. I found that I had just one. Will you please send me some in season for next report? I have nothing more to say except that I have met with sufficient encouragement to warrant my anticipation of a pleasant and profitable year.

\section{Sincerely yours \\ Philena Carkin}

P.S. Do you know any benevolent persons who would like to give my scholars a Christmas treat this year? The fires in Chicago and Boston have kept them out of it for two years. 241

My Dear Mrs. Cheney, Charlottesville Dec 1st/73

I enclose my report for November. You will perceive that my school has increased in number this month. One item in my present report may not be quite

\footnotetext{
${ }^{240}$ Many teachers hired black women to attend to their domestic needs. In doing so, they enabled many black women to improve their economic conditions. See Rupert S. Holland, editor, Letters and Diary of Laura M. Towne: Written from the Sea Islands of South Carolina, 1862-1884 (New York, 1969), 126-27. Also see, Wille Lee Rose, Rehearsal for Reconstruction: the Port Royal Experiment (Indianapolis, 1964), 159. Both works refer to the employment of blacks (women in particular) by the teachers.

${ }^{241}$ A big fire swept Chicago in 1871 and in Boston fires raged for days in 1872. (Edgar Goodspeed, History of the Great Fires (New York, 1873).
} 
correct. I refer to the number enrolled in Oct. I think it was 37, but unfortunately lost my account of it. In regard to the two questions, "Is your school supported in part by public School boards and "Is your school supported in part by Freedmen?" I was in some doubt, but upon consideration, I concluded that the money paid for the rent of the rooms, could not properly be considered as support from outside, but was too such an amount self-supporting. But if you view the matter differently I will credit the amount to the school board, or to the Freedmen. I did not report it this time thinking it best to state my reasons for not doing so, first, and await your decision after looking at the matter once more. I have not received any money from the school board this last month, as Dr. McGhee told me that their funds were low, and they would not be replenished until the first of December when he should be able to pay for both months. He sent me ten dollars worth of wood, as he has made an arrangement with a gentleman to furnish his schools with fuel, and await his (Dr. M) convenience. So we have not been inconvenienced for want of money with the exception of not having enough to pay two bills due to workmen. I shall expect to receive the money this week however.

My school is very interesting now although there are not minutes enough in an hour to get through with an hour's work. I examine the classes taught by my pupils at the end of every month to see how much they have learned. As a general thing they had done very well. One young man failed to do as well as he might by his class. Two others far exceeded my expectations. One of these, a class in Arithmetic, was taught by Joseph Sellers, and the pupils were very thorough and accurate. The other, a class in Grammar, taught by David Smith did themselves and their teacher great credit, as they had never attempted to 
parse a word in their lives before, and can parse simple sentences very readily now.

I have formed a class in Geology in this way. I have nine pupils who are in advance of the rest. Indeed, five of them have taught school. I found in our library a work on Geology and whenever we can get a little time about three times in the week I let one of the pupils take the book and read a paragraph, and then we talk about it until the pupils feel that they understand it, then we read another if we have time. We never occupy more than ten or fifteen minutes in this way, but the pupils have become very much interested. Indeed it is not more interesting to them, than to myself. We propose to have lessons in Natural Philosophy on a similar plan this month. The financial troubles are severely felt among these poor people but there seems to be no falling off from school in consequence, as I feared there might be. We have been favored with good weather thus far, which is a very important item as regards the regularity of my pupils as many of them come from a distance, through the muddy Virginia roads.

With kind regards, I am as ever hopefully yours,

\section{Philena Carkin}

My Dear Mrs. Cheney,

Charlottesville Jan1st/74

I send the "compliment of the season" with hearty good will to all sympathizers and co-workers in the north.

I have had quite a pleasant Christmas this year. The box sent by the ladies of Kings Chapel, gave great satisfaction to all. 242 It was a delightful surprise to the scholars. We made quite a little festival of the occasion. I received several very

\footnotetext{
242 King's Chapel has long been known as a venerable old church in downtown Boston associated with antislavery activity.
} 
pretty presents from my pupils, as this is my last Christmas here. I enjoyed the holidays very much until night before last when there came a sad break into my quiet enjoyment. A house not far from us took fire accidentally about seven- oclock in the evening, and burned to the ground in a short time. It was owned by two colored men. There were three families in the house, and they lost nearly all their furniture and clothing. One of the men had five hundred dollars which he had recently drawn from the bank, the savings of years of hard labor, and as he was away at the time it was all burned. A lady who was visiting there, a teacher from an adjoining county lost everything she had. She had been away in the afternoon, and upon returning home, had undressed and slipped on an old dress, and pair of slippers and sat down by the fire to write. She ran out when the alarm was given and lost everything - nice comfortable clothing and a beautiful new gold watch and chain which were given her that very day. The poor creature did not know where to go for she is comparatively a stranger here, and went around the streets in a state bordering on distraction, almost without clothes (it was the coldest night we have had) until a friend found her and took her in. I sent David out with a paper yesterday morning, and succeeded in raising about ten dollars for the sufferers. I sent all the clothes I could spare from my own wardrobe, and others furnished various garments, so they might have enough to keep them warm. They were all colored people and although quite comfortable in their homes had nothing besides.

In the last letter I received from the Society this question was asked, "Is ten cents per month all they are able to pay? There are some who could pay more, but their (sic) are others who find even that small sum difficult to raise. For instance there is one poor woman who sent five children. She is a seamstress with poor health, and failing eyesight. She had two cows which she sold in order 
to raise money to send her children to school this year. I allowed her to send one without the tax. Another woman who supports her three children by washing and ironing I allowed to send a little girl free of charge, for as they have neither sufficient food nor clothing I knew that even that small sum could not be paid. The money raised by the tax goes to pay for the cleaning up of the schoolroom and halls, making fires, and other extra jobs, about the building. I have taught one boy how to do it as I wish it done, and pay him for it thus enabling him to remain in school. He does a great many little jobs of work, which would cost a great deal if I had to send for a carpenter. With the hope that everything will go on as prosperously this month as last, I remain as ever, sincerely yours

Philena Carkin

Dear Mrs. Cheney Charlottesville Jan 31st/74

Please find enclosed my report for January. I have had a larger attendance this month than at any time before this session, but various causes have combined to lessen the average. Two or three of the new pupils did not enter school until the middle of the month, and one left school about the same time. Besides this, one boy met with quite a severe accident and two others were out some days on account of illness. The others have been very regular. The blank for the Report was made out by Gilly Sellers, a young man who has been a good writer, but I am sorry to say he has grown careless, or else affects a scratching hand, as being more distinguished. He has now gone to Massachusetts to live. David Smith was very much mortified when I told him what you said in regard to his writing - and more so, to think he should have misspelled Alphabet. He prides himself upon knowing how to spell. I had often told him the same that you 
wrote in regard to the unevenness of his writing, but he had become accustomed to my criticisms, and, of course, they had in a measure lost their efficacy. I think he has taken more pains with his writing since your letter came. I think it will do him much good. He is a young man of great intelligence and refined tastes. Is a reader, and keeps himself posted on the general topics of the day. Is delighted with the "Index" and "Boston Commonwealth" (both of which I take) and chooses as models the works of "George Eliot" "Charles Dickens" "Charlotte Bronte" and writers of that stamp.

Next month I must send you a specimen of the handwriting of Lillie Bradley. She is one of my lower class pupils but tries so hard to do well that I gave her the privilege of writing a blank. She is a sweet, but thoroughly simple and undeveloped girl. Still, I think she has the capacity to become a fine woman, and I am trying to bring her out in every way I can. My scholars are doing very well at present, and the other schools are in a flourishing condition. It seems, now, as if the term were drawing to a close - time always flies after February comes in. I have given away quite a number of books from the Library according to the plan we decided upon when I saw you last. There was nothing said about giving them to any others than the pupils, but there occasionally comes before me an opportunity to give a good book to some one who would appreciate it - perhaps more than any pupil I have so I thought I would ask you about it. There is a young man (colored) a graduate from Hampton, who spent his Christmas with one of the teachers here who is also from Hampton. He is a teacher in a country place, called Glendower, about twenty miles from here. He is refined and intelligent, but says he has no society where he is and can get nothing there in the way of books. I loaned him some of my own, for which favor he seemed very grateful. I know of another who is a very superior young man, very highly 
educated, and possessed of uncommon natural abilities. He is from the West Indies, and his family was wealthy, but a reverse of fortune has thrown him upon his own resources (which are not meagre) and he came to the United States to seek his fortune. He is now teaching and doing well, but his means are of course inadequate to supply him with the reading his cultured taste requires, and the kind of books that please him are not easily borrowed, unless one has access to a public library. Now there are in the library some of "Channings Works" the first volume of which is missing. The second, third and fourth volumes are all complete. They would not be appreciated by more than one of my pupils and hardly by the teachers. As the sett is incomplete I thought you would not care to have them returned to Boston, and so I take the liberty to ask you if you would be willing I should give them to either of the teachers I mentioned or to any of the other teachers in the vicinity. The two I spoke of are not of this town, and were never members of this school, so I did not know as you see fit to have any of the books disposed of except they were distributed among persons who are, or have been pupils here. We have had much rain lately and consequently there is no end of mud. The weather is mild now, but has been generally cold since Christmas. Accept my kind regards

\section{Philena Carkin}

P. S. Have read your book and enjoyed it much. 243

\footnotetext{
243 By 1874 Ednah Cheny had written several books: Handbook for American Citizens (1860), Patience (1870), Faithful to the Light and Other Tales (1871), Social Games (1871), and Sally Williams (1873). Her interests were broad, as reflected in the subjects of her books and also in her voluntary activities. She assisted in founding the Boston School of Design for Women, the New England Hospital for Women and Children, the New England Woman's Club, and a Horticultural School for Women. See Allen Johnson and Dumas Malone, editors, Dictionary of American Biography (New York, 1929), 51-52.
} 
My Dear Mrs. Cheney,

Charlottesville Feb 8th/74

I can hardly realize that a whole month has passed since I wrote you before. I have been so busy that I have taken no note of time and one half the school-term has fled away already. I have the same number of pupils this month as last, but owing to sickness, and inclement weather my average attendance is less. Those who have been in constant attendance have made the same improvement in the various branches of study pursued, but the three or four whose nonattendance made such a difference in the average were obliged to fall into a lower class. I have reason to be proud of the progress of some of my pupils, particularly in Arithmetic and Grammar. I have some very promising teachers in my school. George Howard, who teaches a class of beginners in U.S. History; James Anderson, who teachers a class in fractions, and who is particularly thorough in that branch. Harriet Waynes, who teachers reading and spelling. David Smith, who has a fine class in Grammar, and Nancy Brown who teaches Geography. I have some other teachers but these are the most promising.

We have quite an interesting Literary Society which meets once a month. The exercises consist of select readings, essays, debates, declarations, lectures, and the publication (so called) of a paper. This has thus far been edited by Robert Scott, Jr. and has been very well conducted.

(The state schools seem to be during remarkably well this year, are well conducted and filled to overflowing. All the teachers in the colored state schools of this place were Miss Gardner's pupils so her method of teaching is carried out by those whom she instructed. $)^{244}$

\footnotetext{
${ }^{244}$ The parentheses seem to have been added at a later date and in another hand; perhaps for publication in The Freedmen's Record as a testament to the quality of the teachers' endeavors.
} 
The members of the schoolboard seem to feel more real interest in the welfare of the schools than ever before, and have made every effort to promote harmony between the white and colored children, and to carry out the design of a good graded school here. As nothing has occurred out of the "even tenor of our way" for the past month I do not seem to have much to write about this time. My school has been very pleasant thus far and my whole time is filled with work, so if society were possible I should have no opportunity to attend to its demands.

This being the case I am seldom or never lonely. With kind regards to all friends, I remain sincerely yours

\title{
Philena Carkin
}

\author{
My Dear Miss Crocker, \\ Charlottesville Mar 14th/74
}

In reply to your communication of the 4 th inst, and which I received a few days since I would say that as I have had a very pleasant school this year, and know of nothing to prevent my return here another year, it would be very pleasant to do so, if the necessary means can be raised for the purpose. In case you find it impracticable, please let me know as soon as possible, and also what disposition I must make of the furniture and other articles I mentioned in my last letter.

In case this school is given up it will be necessary for me to make some arrangements for my future employment, and would therefore like [to] be informed of your decision at as early a day as possible. 
The death of Charles Sumner has cast a gloom over us here for the colored people feel that their best friend has gone. 245

\author{
Sincerely yours \\ Philena Carkin
}

[Ph. Carkin Feb. 28.'74] $]^{246}$

My Dear Mrs. Cheney Charlottesville Mar' 28/74

I have talked with Mr. \& Mrs. Lewis and Robert Scott in regard to the questions you asked me and after giving the subject much thought have come to the following conclusions.

Upon the white people in general, it will have no particular effect, as they take no interest in the colored schools, or at least they manifest none.

Upon the colored people, the effect would depend mainly upon whether the school was kept up as it is at present, and I will consider that question as being the main part of the subject. The question was asked Dr. McGhee by Robert Scott, whether, in the event of the Society withdrawing its assistance the Normal Department would still be kept up. He answered that as there were pupils sufficient for five schools that would undoubtedly be the case. I do not think there is any question as to whether they will keep up a school. But there is much doubt as to their keeping it up as at present. In the first place everything depends upon the teachers whose services they engage, as they leave the

\footnotetext{
${ }^{245}$ The Harvard-educated, United States senator from Massachusetts, Charles Sumner, became a leader in the abolitionist movement in the late 1840s. He argued for integrated public schools in Massachusetts in the Roberts Case of 1849, campaigned against slavery and later asked President Lincoln to sponsor legislation to free the slaves and grant civil rights. See David Donald, Charles Sumner and the Coming of the Civil War (New York, 1960). Also see Beverly Wilson, editor, Selected Letters of Charles Sumner, (Berkley, 1990)] 2 volumes.

246 Written in unidentified hand.
} 
whole matter of grading and all the care of the building etc to them. This is not as it should be, for some of the teachers are opposed to the grading of the school, at all, and when it is left to them they do not always send their most promising and advanced pupils into the higher departments but ask their pupils which ones wish to go and send them accordingly so if the teacher of the higher department fails in vigilance she will find herself with an inferior class of pupils in her room.

Secondly, I do not think they would employ a first-class teacher, from the fact, that they do not pay a sufficiently high salary to secure such as one.

Thirty-five dollars per month is probably all they would be willing to pay, and even that would be given grudgingly.

They would also wish the teacher to instruct at least fifty pupils, which is too many unless the grade is lowered as it would necessarily be. In fact I do not think there would be any regularly graded school after the first year, but the whole matter would be left to the whims of the parents and the choices of the teachers. Upon the more advanced pupils the effect would be simply this, they would leave the school altogether and seek instruction in some other place, or turn their minds to some employment. I wish I could have presented a brighter picture of the prospects of the Jefferson School, but that is impossible. I can truly say that I have never had a more successful year, and when I leave I shall carry with me many pleasant memories of my last session at Charlottesville. And now I wish to ask what disposal you would like to have made of certain articles of property belonging to the Society. There are four stoves, one in each school room, a magnetic globe, two setts (sic) of outline maps, one Worcester unabridged Dictionary, and quite a library of books. These books will soon be destroyed or lost after the school is given up unless they are removed from here, 
or disposed of by giving some of them to those of the more advanced pupils who would be able to appreciate them. The Dictionary would also be ruined in a short time. If there is anything here you wish to have sold, it will be necessary to begin to make arrangements about it at once, as people are poor and wages low, and when they wish to buy an article, they need a long time in order to plan their little earnings in such a way as to be able to pay for it. I have already arranged for the sale of some of my own articles of furniture in this way.

I enclose my report for the month. You will perceive their (sic) has been a slight falling off in numbers this month, although the average attendance has been very good when we take into consideration the muddy state of the roads, etc. The progress in the different branches has been excellent, and there seems to be good talent for teaching developing among those who have classes under their instruction.

\section{Sincerely Yours}

Philena Carkin 
Yours of the 21 st ult. came to hand in due season. I can scarcely realize that the N. E. Society has really disbanded - it has been so long in operation. 247 । can hardly think what would have been the condition of the colored people of the South now, but for the good work it has carried on. I shall wait anxiously to know what disposition is to be made of the Charlottesville school, so in event of its non continuance, I shall need all the time I can have to dispose of articles of furniture, and make other preparations for breaking up, to say nothing of looking abroad for some other field of labor.

I expect to have an examination of my school in a few days. I have it this early, as many of my scholars are about to leave, in order to commence their Spring work. I have or had a very fine class of ten pupils, but two of them have already left school. They have improved very rapidly, and some of them have not been absent more than two or three days for the entire session. It has been a hard winter in some respects. The money panic made it very hard for the laboring poor but, as if in compensation, the winter has been quite mild. The schools have all been, and still are, well fitted and seem to be doing well generally.

The colored people held a Memorial Meeting in the large lower room in the memory of the services of Charles Sumner. 248 Quite a number of the young men spoke. There was (sic) a large number of persons present, and resolutions testifying respect for the memory and sorrow for the loss, of the great Senator were adopted. The whole audience were (sic) very quiet and seemed very much

\footnotetext{
${ }^{247}$ Formed in 1862, the New England Freedmen's Aid Society merged with other freedmen's aid societies to form the American Freedmen's and Union Commission on Oct. 5, 1865. As a branch of the parent organization, the NEFAS published the Freedmen's Record, a monthly organ. The New England branch retained its official boards and also interacted with the main body on a regular basis. (The Freedmen's Record, December 1865, p.189).

${ }^{248}$ Charlottesville Chronicle, April 1874.
} 
impressed with a sense of loss. I shall be glad to know whether this school is to be closed at the end of the year as soon as the committee have (sic) been able to make their arrangements. If I am to return I can make many little necessary preparations before the close of school. There are several pupils who will probably continue in school in case it is kept up at present, but who will probably either give up school altogether or go away, to Washington, or Hampton if the Society work is closed here. With kind regards I remain as ever

Sincerely yours Philena Carkin

Dear Mrs. Cheney, Charlottesville May 2d/74

I enclose my report for April. You will perceive that there has been quite a falling off in number this month, and there will probably be as large a decrease before my next report. You may think it somewhat strange that I have not admitted other pupils in the place of those who have left. I did intend to do so and asked Robert Scott to send in some from his room and then refill from the lower rooms. He said he would do so but failed to send in any, so I spoke to him again after a week or two. He said he would send them soon. I heard no more from him. When Dr. McGhee came to pay the rent I spoke to him about it. He acknowledged that the pupils ought to be sent in, but said that some of the teachers were unwilling to part with their pupils etc. after working on them. He said he was told by some of the teachers that the parents of certain children were unwilling to send their children to my school, on account of the monthly tax of ten cents, and because they would have to buy some new books when they came 
into my room. So he thought it best to get along as easy as possible for the short time the term would last, and another year, the pupils should be put forward into higher departments as soon as qualified. I found partly from his conversation, and partly from another source, that Mrs. Gibbons and Robt. Scott had been to him to protest against being obliged to send their scholars into higher departments and worst of all, it was quite evident from what he said, that one or both of them misrepresented things very much, as in regard to the parents complaining of having to make a change of books etc. 249 I have not written this in way of complaint, but to show you that it is not my fault that my school is not full.

Dr. McGhee asked me, if in event of your giving up the school here in the course of another year you would like to sell or rent this property. I told him that I did not understand how it was held and referred him to Judge Rives. He requested me to ask you about it when I wrote. I knew that there is a great deal of personal property which you might dispose of to some advantage I should suppose, when the school is given up. The desks and stoves etc. which certainly belong to the Society whether the land and buildings do or not. We have had a great deal of rain this month and what is worse, because it has a more depressing influence upon the school than anything else, we are having a storm of revivals. Since this commenced I have found it impossible [to] arouse an interest in the lessons. No wonder, when the poor children are crowded and packed into a hot, close room two thirds of every night, listening to the shouts and groans of the revivalists. I only wonder that they are able to come to school at all.

249 Reverend and Mrs. Isabella Gibbons were members of the First Baptist Church on Main Street (the black church). Her salary was paid by the NEFAS. 
With kind regards, I remain sincerely yours

P. Carkin.

P. S. Shall lay my plans for another year here unless I hear from you to the contrary.

P.C.

My Dear Mrs. Cheney

Charlottesville June 1st/74

I send my May report by which you will perceive that I have had but (twentyfive) pupils this month, with an average attendance of nineteen. This is better than I expected when I wrote you last, as the Spring is the time when the larger ones leave to commence work. I shall have a smaller number in June, as two of my pupils notified me Friday that they should be unable to attend school any longer this year.

I sent your letter to Judge Rives and your message to Dr. McGhee as requested. I presume you have heard from Robt Scott re this, as Mr. Lewis told me that he showed him the letter and said he should answer it immediately. In regard to the number of pupils ready for one [another year], I know that he has had a large number fitted for my department for several months past. I do not think it likely that he has less than twenty who have arrived at the point in their various studies which used to be the standard for entering Miss Gardner's school when she was here. So nearly as I can judge now from the number of my present class who intend to continue their studies another year, and the number that I know to be ready for my department, I should have a school of more than forty pupils-- perhaps nearly fifty. Dr. McGhee assured me that the grading 
should be properly attended to if I returned next season - that as often as a vacancy occurred in my ranks, it should be filled from the next department. I must say, that I think that Robt took the school with the right feeling, and with a desire to carry out your intention in regard to transferring his best pupils to me, etc. but he is quite intimate at Mrs. Gibbons and very much under her influence, and she has been opposed to it from the first, and has used his influence over Robt. until he has been made to feel that it is a hard thing to teach pupils until they begin to be interesting and then tum them over to some one else.

As far as Mr. Lewis is concerned, he shows the right spirit in this matter. He says Mrs. G. and Robt talked with him about it, and wanted to know if he was ready to send out some of his pupils. He told them "Yes." That the oftener he could fit a class for a higher department the better he was satisfied.

I have had a class of nine pupils this season who, as far as education is concerned, are much in advance of the majority of teachers about here. I have only four in school now as two left in May - one the last day of the month. Mr. Powers, the Superintendent, told me two months ago that he should want some of them another year, as they were obliged to take very inferior teachers in many instances because they could not find those who were qualified. He likes the plan of this school, and wants it to be properly graded, but as he lives at a distance he cannot attend so well to the matter as I am sure he would if he were in town. Hoping to hear from you soon, in order that I may know whether I am to return or not so to be able to make the right preparation, I remain, yours sincerely

\section{Philena Carkin}


Dear Miss Crocker,

Tyngsboro July 5 th/74

You will doubtless be surprised at receiving this letter and I hesitated at first about writing to you, but finally concluded it could do no harm if it did no good.

When I came on I brought with me a boy - one of my best scholars - as far as New York City and from there he went on to Saratoga to work during the summer in order to earn money to enable him to attend school another year. His trunk was checked to New York and the baggage express man took the check and gave him a transfer. When he arrived at the depot the trunk had not come and he waited until the last train for its appearance and then he gave the number of his transfer to the baggage master who promised to send it to him per express. He has now been there a week, and although he has telegraphed repeatedly he has heard nothing from it. In the meantime he has been obliged to spend what little money he had left in order to purchase clothes to work in and I fear the loss will prevent his being able to attend school another year. He is my best scholar, and most promising teacher, and I wish very much to have him obtain a thorough education. $\mathrm{He}$ is the son of a very poor widow and but for the little assistance I have been able to render him could not have had the opportunity to learn what he has done. My object in writing to you is to ascertain if there are any ladies or other friends who would be willing to assist in making good a portion of his losses. I know a trunk seems a small thing to lose but it contained all he had in the world, and its loss will probably prevent his obtaining the education necessary to his success as a teacher. Mrs. Cheney told me that the ladies of the West Roxbury Society were to have an interest in my school. 250 I did not

\footnotetext{
${ }^{250}$ The ladies of the West Roxbury Society had contributed many times to helping the freedpeople. The women frequently sent clothing to the South and sponsored teachers through NEFAS. One of the teachers the group sponsored was Mrs. Isabella Gibbons. Freedmen's Record, 1866, p. 100. See also, Lori D.
} 
know but that they might be inclined to make an effort to raise a small sum for him. I could write to Mrs. Foote and I have no doubt she would do something at once, but I have applied to her for assistance in two or three cases before now, and her society have always responded very readily, and I naturally feel a delicacy in making too many applications to one person or Society. 251

If you think the matter of sufficient importance to take the trouble, will you oblige me by sending this letter to the W. Roxbury ladies or Mrs. Foote or anywhere you may see fit. Any sum however small will be acceptable, and I will add to it all I can afford. I would write to the W. Roxbury ladies, but do not know any address. I do not think he will ever recover the trunk and even if he does, the expense its loss has put him to will be very great for him. My address is Tyngsboro Mass. and anything sent to me will be immediately used for him, either in purchasing clothing to send him or forwarded as money just as he prefers. He does not know that I make this application for him as I do not wish to raise any hopes which may be disappointed. Excuse me for troubling you in this matter, but I knew you were always ready to do what you could to encourage promising scholars.

\section{Yours truly}

\section{Philena Carkin}

\footnotetext{
Ginzberg, Women and the Work of Benevolence: Morality, Politics, and Class in the 19th Century United States (New Haven Press, 1990). Although Anne Boylan's study "Women in Groups: An Analysis of Women's Benevolent Organizations in New York and Boston, 1797-1840" in the Journal of American History (December 1984), 497-523, is of an earlier period, it is useful in providing an interpretive framework.

251 "Mrs. Foote" has not been identified.
} 
Dear Miss Crocker

Tyngsboro July 26th/74

Yours of the 17th inst came duly to hand and today I received a letter from Mrs. Cheney. She advises me to make application to the express or R. R. Co. as you had previously done. A letter from David informed me that he had received his trunk at last, but it did not reach him until he had spent the whole of his money (about twenty-five dollars) partly in telegraphing for his trunk and the rest in the purchase of clothing to work in, as they would not give him any work in the hotels until he had a certain number of vests, jackets, aprons, cravats etc. etc. Of course all this was a needless expense as with my advice and assistance he had furnished himself with nearly everything that was necessary before leaving Charlottesville. Besides the expense of purchasing clothing, his trunk was open, and much damaged, when it reached him although the contents were undisturbed. I know it was securely fastened as I superintended it myself. It was locked, and strapped and over that a cover was securely nailed around and then it was corded. It must have been purposely detained and opened. There was no irregularity in getting the transfer for I was present and saw that it was all right. If I knew the name of the Express Co., I would make the application you advised (although I do not think we could recover anything without a lawsuit and that David has no means to carry one and I could not afford to do it without a certainty of success) but I do not remember the name on the transfer. I have written to David to ascertain but have not, as yet, heard from him. I will now state his case as plainly as possible in order that you may see whether he ought to be assisted. In the first place he has no home and works for his board when in Charlottesville. For the last two years he has worked for me and for Miss $\mathrm{H}$. when she was there and we gave him his board and let him lodge in a rough room in the garret. In the summer he works for some hotel proprietor in order to obtain the means to 
furnish himself with books and clothing. He will be likely to work at Saratoga about two months (perhaps less). He receives $\$ 25.00$ per month which will amount to $\$ 50.00$. When through with his work he will come here and work for his board until time to return to Virginia. Of course I shall do all I can for him while here, but we have but little for a boy to do, and he is entirely (unaccustomed) to farm work, which seems to be the only thing there is to do at present. After he has paid his expenses from Saratoga here and from here to Virginia, he will have about fifteen dollars left for the purchase of books and clothing. I am very anxious to retain him in school this year and perhaps I can assist him sufficiently to enable him to attend a part of the term at least. He has never been alienated from us on account of religious bigotry and has rendered me valuable assistance by his upright conduct and general intelligence. He does not know that I have made any application for assistance for him and I shall keep him in ignorance of it as Mrs. Cheney thinks it best not to make an application to the W. Roxbury Society but let the matter rest at present. I have been thus particular in explaining all the circumstances to you in order that you might see why I felt a desire to obtain assistance for him. I hesitated about applying but concluded that the object was worthy the attempt. Excuse me for troubling you. I would write Mrs. Cheney but her letter was mailed at York Ave. and I do not know how long she proposes to stay there.

\author{
Sincerely Yours \\ P. Carkin
}


Pardon my seeming remissness in letting a whole month pass without writing to you. I should have done so but for some unforseen circumstances which I will explain. In the first place when I arrived here I found Paul Lewis had moved his family away, and that necessarily delayed my arrangements for being settled to housekeeping. I reached here Saturday and the woman whom I engaged could not come in until Monday evening. I did not like to postpone commencing school so I opened Tuesday morning, and what with teaching regularly and sharing housecleaning, putting down carpets, setting stoves, getting in the necessary provisions and fuel, of which had [to be] done at odd times, when I could [unclear] two whole weeks passed away before I was settled. I found no time to go to see Mr. Scott except in the evening and that was out of the question, as I never go out evenings here. I sent word that I wished to see him and he said he would come up here, consequently, having so little time to go out (and, I must confess, so little inclination to call there) that I have waited for him, and look for him today. There are some little repairs needed to make the house comfortable for winter and I shall endeavor to make him get them done. You will remember that I wrote you two years ago that Mr. Scott told me that the property was deeded to him and Mr. Gilmer and Mr. Lewis as individuals instead of trustees. I was not here at the time the land was purchased, it being the year I was called home on account of my sister's illness and health, so I did not know but that it might be so, as he said it was done with Miss Gardner's advice. Since coming here it occurred to me to mention the circumstance in a letter to Miss G. She wrote in reply that she had not had it done. So it seems that the arrangement was wholly Mr. Scott's. Not much to his credit however, I think.

Robert Scott is not teaching here this year, but has gone to Harrisonburg, Va. where he commands a higher salary. Egbert Gerry teaches in his place, and his 
(Egbert's) place is filled by one of my old pupils, who has graduated from Hampton, Benjamin Tonsler. 252 His mother lives in the house and does my work. On the whole I think that matters are somewhat better than they were last year as out of the corps of teachers I have only two to work against my plans this year, as Benjamin enters heart and soul into my plans in every respect. I wish he could have had Robert's place, as he could have done much in that position, and is better qualified than Egbert. As to the change of families, I really want words to express the relief it is to me not to have those seven noisy children of Paul Lewis here. It was out of the question for Margaret to attend to my work properly with such a family of her own, consequently the much larger share fell upon my own shoulders. Mrs. Tonsler relieves one of a good many little burdens, not much in themselves, but a little hard after working in school all day and I find it a great relief indeed.

You will perceive that I have but twenty-six pupils this month. This is in consequence of the more advanced pupils in the next grade not having entered school as yet. We are never able to fill up our schools in October. Of my own more advanced pupils - that is, of a class of nine grown young men and women

${ }^{252}$ Benjamin Tonsler later became principal of the black Jefferson Elementary School; city officials later named a playground in his honor. He was also an active member of First Baptist Church on Main Street. See Richard I. McKinney "Keeping the Faith," in Magazine of Albemarle County History, 31 (1981), 92. In April of 1868, Hampton Institute opened in Virginia headed by Samuel Chapman Armstrong. (Chapman was a former Union officer and an advocate of agricultural-industrial training for the freed blacks). When Tonsler died on March 6, 1917, Charlotteville's citizens took note. As the prinicipal of the Jefferson School, and a community leader, Tonsler had earned the respect of many citizens both near and far. "By his earnestness and devotion to the upbuilding of is race he has earned a high place in the estimation of the school authorities of the state. These were strong words, particularly in the early twentieth century, when violence against African Americans was rampant. Before summer began in 1917 an estimated crowd of 1000 people gathered at akwood Cemetery and dedicated a monument to him and his work. Tonsler had been the principal of Jefferson Elementary School for Colored Children for twenty-two years. Daily Progress, March 7, 1917. Between 1882 and 1928, eighty-eight blacks were lynched in Virginia despite a 1878 law enacted by the General Assembly that prohibited such barbarity. Also see, June Purcell Guild, Black Laws of Virginia (Richmond: Whittet and Shepperson, 1936) p. 170-71. Also, Workers of the Writers' Program of the Works Projects Administration of Virginia, The Negro in Virginia (New York: Arno Press and the New York Times), 1969, p. 243. 
to whom I devoted special attention last year, four are now teaching in different parts of the state. One has entered the senior class at Hampton, with the expectation of teaching next year. One young man is expecting to open a school soon, and one young woman has been ill during the summer and is neither teaching nor attending school. The other two (young men of great promise) are still in my school and doing well. I think they intend to devote two or three years more to study if possible.

School is now in good running order and we have spent the past month mostly in reviewing last year's lessons and picking up broken threads here and there in order to be able to go on smoothly with our work. If nothing prevents I shall fit a number more for teachers this year. Can you give me Mr. Ruffin's address? 253 I had it at one time but have lost it. He told me when here that he was very anxious this school should be properly graded, etc. and requested me to

let him know if it was not. As Mrs. Gibbons and Egbert Gerry are opposed to grading, and the members of the Board a little weak generally, I would like to know his address in case it should be necessary. Of course I shall wait a week or two before writing to him in order to see if they are disposed to do what is right. But in case they fail in their duty, do you not think it best to let him know? Please give me your opinion on the matter. You can see I do not have the utmost confidence in Dr. McGhee. In regard to the rent they readily acceded to the payment of the sum required at 25.00 per month so I have no tax to trouble me this year.

I think you told me that a society in W. Roxbury was interested in my school this year. I wish to give my scholars a Christmas Festival this year, as it is the

${ }^{253}$ A freedmen's bureau agent. 
last time I shall be with them. Do you think they or the ladies of King's Chapel, would send us a box to make merry with? If so I would like to know as soon as possible as there are a few things that certain persons here would like to send on and purchase. Clothing is very high here - that is certain articles - and if I could know that a box was to be sent I would endeavor to assist some of the very poor in getting a few things at a lower price in Boston. As a few women have said they would like to buy some such grey flannel underskirts, as were sent me at one time and some young men of limited means would like to provide themselves with good second hand overcoats, which are almost as necessary here in midwinter as at home, but which their means are not sufficient to provide. Young men who work in boarding houses here only receive 8 or 10 dollars per month, and have to provide themselves with a room out of that. You will see at once that they have to calculate very closely in regard to clothing. With kind regards I remain sincerely yours

Philena Carkin

Dear Mrs. Cheney, Charlottesville Dec 4th/74

I enclose with this a report for November and hope you will perceive a slight improvement in regard to punctuality. I should have stated in my other letter that the cause of the low average etc. was that some of the pupils did not commence school until a week or more after the opening, and were it not for the fact that I have three or four girls, who are obliged to absent themselves from school one day in a week, my attendance would be almost perfect. I do not feel right to tell these girls that they cannot be permitted to come to school in this way, from the 
fact that they are good steady scholars in every other respect, and two of them are nearly fitted to teach and if they could not have the one day they would be obliged to stop school altogether. One of the girls, in particular has a very hard time, as she has no parents and lives with an aunt who makes a perfect slave of her. Her uncle keeps a restaurant, and she is often compelled to be up as late as twelve or one o'clock at night cooking, and waiting upon customers. She is only fifteen years of age, and is a quiet, modest girl, and one of my most promising pupils. I could not have the heart to refuse her admission on account of her forced absence. The other cases are not quite so bad but similar in some respects. These girls make up in studiousness what they lack in punctuality and with one exception keep up with their classes.

I acted upon your advice and wrote to Mrs. Foote about a Christmas box. She wrote in reply that she was happy to be able to promise me one, and that one of the ladies knew you and would communicate directly with you.

My school has been very pleasant this month, and the pupils have in most cases made very marked progress.

My plan is to examine the classes taught by the advanced pupils at the end of each month and see what progress has been made. I am pleased to be able to tell you that the examination was most satisfactory. I know of nothing that develops a pupil's thinking faculties so rapidly and efficiently as having a class to teach. I must mention one of my pupils - a little boy eight years of age, as I consider him one of the most wonderful children I ever met. He is a beautiful reader, and studies Arithmetic, Geography, and Grammar, and learns them, not merely by rote, but seems to have such a clear understanding of all that is comprehended in those branches. He could easily take lessons in History and Philosophy if I thought it judicious to cram his little brain to that extent, but I think 
he has all the study that is good for him. I very much fear that his parents and teachers may push him along too fast after this year, but while I stay I shall be careful not to give him too much study. He is far in advance of his years in other respects as for example, in being trusty and respectable etc. With judicious training he will be a credit, not only to his race, but to mankind generally. With kind regards I remain as ever truly yours

\section{Philena Carkin}

P.S. Will you please send me a few blanks for my reports? I have but one more.

Dear Mrs. Cheney, Charlottesville Dec 27th/74

My conscience smites me because I have not written to you before now and acknowledged the receipt of the two beautiful presents you sent me, for which accept my thanks. I prize them both--particularly the book, although I have not yet had time to read it. It has been a very busy month with me, both in school and out, for it has taken all my spare time to make arrangements for our Christmas Festival which took place last Friday evening and was a perfect success. One of my former pupils (who last year graduated at Hampton) played the part of Santa Claus, and made them all very merry with quaint remarks while he distributed the gifts. My little boy seemed in ecstasies of delight. It was enough to make one happy to see him. We had a few tableaux in which he figured conspicuously and he also spoke a piece called "Christmas Times" for which he was heartily applauded.

I forgot to tell you in my last letter that the girls I mentioned as being absent, do have a definite day for that purpose, and they have each chosen the day on which they have the least to do in school. One of them teaches a class in 
Arithmetic, and as we omit that lesson Wednesdays, she stays at home that day in preference to another. They are very punctual in every other respect.

You spoke of the account of our Society in the Woman's Journal. 254 I was not aware that there had been an account published of it. Previous to our Festival I wrote to Lucy Stone in regard to having a song printed for the occasion [unclear] and she sent us a very kind and encouraging letter, so in reply I wrote her giving an account of the Festival, not thinking our little efforts here would be thought worthy of notice. 255 If I knew the number of the paper, I would send for a few copies, for the encouragement of these girls, who are beginning to learn that freedom of opinion costs (sic) something.

Accept my thanks for the kindly interest you manifest in my future welfare. I have no definite plan as yet and it is hard for me to settle upon anything as I do not feel willing to leave my mother again as she is now seventy-two years of age and quite broken in her mind. If I find that a word from you will be of advantage to me, I shall not hesitate [to] accept your kind offer. I send my report with this. The blank was prepared by my best pupil-David Smith-I am sorry to say that he is not a particularly neat writer. He is superior in many respects to those who went out as teachers at the close of last session. He is my chief assistant in school, and teaches a class in Arithmetic who are now working in Decimals, and

254 The Woman's Journal_was published on January 8, 1870, by the American Woman Suffrage Association (AWSA). The editor in chief, Mary Livermore, was part of a well-connected, Boston-based group who formed a stock company that provided the capital. The publication merged with Woman Citizen in 1917, three years before passage of the 19th amendment. See Doris Weatherford, American Women's History (New York, 1994), 379.

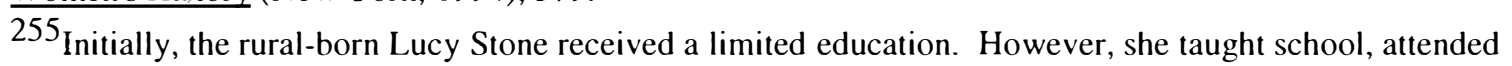
Mt. Holyoke and Oberlin and married Samuel Blackwell all while maintaining an involvement in the abolitionist movement. She edited the Woman's Journal from 1872-1893. (Andrea Moore Kerr, Lucy Stone: Speaking Out For Equality (New Brunswick, 1992). For a glimpse into Lucy Stone' personal relationships, see Loving Warriors: Selected Letters of Lucy Stone and Henry B. Blackwell, 1853-1893, edited by Leslie Wheeler (New York, 1981) and Friends and Sisters: Letters between Lucy Stone and Antoinette Brown Blackwell, edited by Carol Lasser and Marlene Deahl Merrill (Urbana, 1987). Both studies also provide insights into New England antislavery society. 
he often supplies the place of teacher in one of the other schools, when the regular instructor is sick or called away. He has taught for me two or three days this year when I have been too unwell to go into the schoolroom and arranged the school beautifully. I am quite proud of him. The little boy I spoke of in my last is the only one I have of that age. I have two other pupils only eleven years old. The rest are from twelve to twenty-two. Accept my sincere wishes for a Merry Christmas and Happy New Year. Sincerely yours

\section{Philena Carkin}

Dear Mrs. Cheney Charlottesville Feb 28th/ 75

It scarcely seems possible that the time has come for me to report myself and school again, but my calendar tells me that it is the last day of winter.

I enclose my report for Feb. Considering the numerous obstacles in the shape of snow, wind, rain, mud, and cold weather that we have had to contend with for the last five weeks, I think we have done remarkably well. There have been a good many days when the mud was nearly ankle-deep at our door, and the roads outside of town were in a state impossible to describe. Still the scholars got here in some way. I scarcely know how, for if anything would cool my enthusiasm for going out, it would be the sight of Virginia mud.

The [unclear] for report for this month was made out by Miss Sallie Bradley, a beautiful young girl less than sixteen years of age. She has been to school but little, but learns very well, is easy and ladylike in her manners, neat in her dress, quiet, modest, sensible, and well-behaved besides being very handsome. I 
regret that she cannot have the advantage of a higher state of society for she is capable of becoming an ornament to her race in more senses than one.

Some of the [unclear] questions in her blank were misplaced and I did not perceive the error until I went to make it out this morning - too late to have it rewritten.

The next four months will pass away so rapidly that I think I had better speak to you on the subject of the Dictionary, and Encyclopedia of which we have two setts (sic). A young man, one of the teachers asked me if the Dictionary was to be sold. If so he would like to buy it and also one sett of the Encyclopaedias if they came within his means. The Dictionary has been in use seven years and is of course some worn, and one leaf is partly torn out. I do not know the price of a new one, and therefore should not know what to value this at. If you will let me know what you think a fair price I will tell him and if he does not feel able to take it perhaps I will buy it myself as I have no large one of my own. One sett of the Encyclopaedias is in fifteen large volumes. It is an old British sett called the "Penny Encyclopaedias." The other is the "Encyclopaedia of Americana" and is in twelve Vols. They are both old setts but well preserved and we find them very useful. If you would like to have them sold and will tell me about what you think to be a fair price I may be able to dispose of them. I know that everything that is left to the public schools will be destroyed, for the teachers are not careful, and the school Board would feel no interest in anything of the kind.

With kind regards I am so ever sincerely yours,

$$
\text { Philena Carkin }
$$


I write as you requested to lay before you what little matter of business occurs to me at this time, although there seems to be but little just now. I presume some little matters which cannot be foreseen will present themselves after awhile. At present the chief thing that occurs to me is the matter of disposing of the stoves and desks. You authorized me to dispose of them to the schoolboard if possible, but it occurred to me that perhaps the matter would meet with more consideration if the proposition were to come directly from you. There are something over one hundred desks, and they cost $\$ 2.50$ each. They have been well taken care of and are not cut and injured as one often sees the furniture of Virginia schools. I think it no more than right that the Society should hold them and sell them for what they can get for them. There are also five stoves, one in each schoolroom-three of them being nearly as good as new. I do not suppose they will be willing to pay more than one fourth of the actual value of the stoves and desks, but I think that would be much better than giving them away and if they do not feel willing to buy them at all, I can dispose of the stoves at some of the stores here. I would suggest that perhaps it would be better not to lay the matter before the schoolboard until later in the season, say about May, or June or if they purchased the furniture they might feel a kind of proprietorship in the building and wish to deduct it from the rent. I don't presume to advise, however but just lay the matter before you for consideration. I would also say that, as in all probability it will take me several days, perhaps two weeks, to get all the little matters of closing up arranged satisfactorally. I would like to be allowed to close my school about the middle of June, if I find it necessary to do so. I shall try to have everything done as rapidly as possible, but people here are very slow, and besides closing up the affairs pertaining to the school, I shall have my own furniture to dispose of etc. 
I have racked my brains to think about other business I have to lay before you, but nothing more occurs to me. The colored people have held a meeting to testify their joy and gratitude for the passage of the Civil Rights Bill. 256 The mud has been so bad here that people have been unable to come in from the country with teams, but it is drying rapidly now.

\section{Truly Yours}

\section{Philena Carkin}

P. S. There is a set of Collins outline maps here. I suppose you would like to have them sold. If I cannot sell them, shall I send them to you or leave them here?

Note: Written in another hand: Not send anything north but get it into the best hands at any price[.] Outline Maps to Paul Lewis.

Dear Mrs. Cheney Charlottesville Apr 4th/75

I enclose my report for March, the blank of which was made out by William Watson, a young man of seventeen. He has been a pupil in my school off and on for the last six years, is possessed of more than ordinary ability, and is steady and reliable.

Unfortunately, his father cannot be made to see that a good education is of greater importance than the pitiful sums he can earn doing little jobs for people, so William usually gets about two months in the year to attend school and in this

\footnotetext{
${ }^{256}$ The Civil Rights Bill prohibited discrimination in places of public accommodation. The bill, however, was ruled unconstitutional by the United States Supreme Court in the Civil Rights Cases of 1883. Not until the 1964 Public Accommodations Act did Congress once again pass a law opening public places to all on a nondiscriminatory basis. See Edgar A. Toppin, A Biographical History of Blacks in America Since 1528 (New York, 1969), 143.
} 
way has picked up a little education. He has one important qualification for a teacher - he is a good reader. He might have been among the most advanced pupils of this school had he been allowed to attend school steadily.

I thank the Committee most sincerely for their present and for their kind words to me, and I shall always look back upon my connection with them as one of the pleasant remembrances of my life. In regard to the present of the maps to Mr. Lewis, I have not given them as yet for the reason that he already has a sett of his own, which were sent him some years ago by Miss Francis, I think.

I thought perhaps, that being the case you would rather he should have something else. Mrs. Gibbons has also a sett of maps which were sent her by the W. Roxbury people. I will give him the maps if you still think best. I have not given Mrs. Gibbons the book yet, as I thought I should wait until I heard from you again and found what you would like to have done with the maps, whether to give them to Mr. L. or something else in their place.

One thing I forgot to mention in my other letter was the globe. It is a magnetic globe, and has been in use six years. One of Miss Gardner's pupils knocked it off the stand and injured it somewhat when it was nearly new. I am sorry it slipped my mind when I wrote before. I might possibly be able to sell it for a small sum, and I might not. What shall I do about it? It is likely that several of my larger pupils will leave school this month. Two of the girls expect to go to Massachusetts in three weeks, and some others will probably leave. I can not help a feeling of sadness when I think that I shall soon leave this scene, and these scholars, some of whom have grown from little children to young men and women in my school, but I shall always have the satisfaction of knowing there has been great improvement since I came here nine years ago, and I trust that 
the colored people will yet make [a] bright mark in our future history. Accept my kind regard

\section{Philena Carkin}

Dear Mrs. Cheney, Charlottesville June 4/75

A few weeks will terminate my long stay in this place and I have my hours of sadness and my hours of retrospection also, and when I look back over the nine years I have been here, I can hardly persuade myself that this is the same place. In my impatience and haste, it has often seemed as if the wheels of progress had ceased to move, but when I remember the spring I came here, nine years ago, the change is very apparent. In those times I used often to write two, three, and four letters per day for the colored people. Now I am never called upon, as there is scarcely a family in which they have not some one who can wield the pen. Then it was a rare thing to find a colored man with a home of his own. Now I can count dozens of neat cottages (in sight of my window) built and owned by colored men. Although there is much to discourage and sadden, the prospect is cheering, for I truly believe the colored people are improving mentally, morally, religiously and physically, and with the colored people I feel that the South must rise or fall. I am glad to give my testimony of the cheerful side, although I do not ignore the evils of ignorance or superstition, intemperance, dishonesty etc which are so frightfully prevalent here.

My school has dwindled away to a little more than half of the number I had in the winter. Those who are still in school are doing remarkably well. I am particularly proud of the passing of some of my smaller boys - those who knew nothing about Grammar until this year. My little boy of whom I spoke in a 
previous letter, would surprise you by the manner in which he can dispose of a sentence. He is a dear, manly little fellow, and never asks for assistance with any lesson until he has exerted his own little brain to the utmost, and then when a leading question, or a word of explanation has set him on the right track it would do you good to see the sunshine in his face. There never was a happier little face than his when he has conquered a difficult task. It would make sunshine in the cloudiest day. He always brings me a smile every morning, but as to that, he is such a general favorite, that every one of the pupils smile at him, so I suppose smiling comes easy to him.

I saw Dr. McGhee yesterday and spoke to him about the school furniture. He will let me know what action the board will take, early in the week. I think they will take the desks and stoves.

Will there be any Committee Meeting in July where I can see you and close up the affairs of this place? I have sold the Encyclopaedias for $\$ 5.00$. The other schools are doing well.

The mountains are beautiful now although the season has been an unusually dry one, and the freeze in April killed all the early fruit and vegetables.

Truly yours,

Philena Carkin

Dear Mrs. Cheney Charlottesville June21/75

I enclose my last report - the one for June - by which you will perceive that I had a very small number of pupils this month. I knew that it would require some days to settle up the school affairs properly so I closed school last Wednesday. I have, however, two advanced pupils who come in a little while every day and 
practice on their arithmetic as they are expecting to teach and I wish them to be very thorough. They are the best scholars I have ever had, and I wish to give them every advantage I can in order that they may do themselves credit as teachers. Robert Scott has applied for the situation as Principal. I do not know whether he will succeed in obtaining it or not. I could have retained the school under the Board had I been so disposed but I feel that duty calls me home now, as my mother is old and much broken in her mind. I have sold the desks, stoves and Encyclopaedias, according to your directions. For the desks the Board allowed $\$ 100.00$ for the stoves $\$ 10.00$ and the Encyclopaedias were sold for 5.00 making in all 115.00. This is much better than I expected to do with them, and it is a great relief to feel the matter is settled. I have several articles of furniture etc. belonging to myself which I must dispose of and then I shall be ready to leave. Dr. McGhee desired me to tender his kindest regards to you and express his appreciation of the service you have rendered the cause of education here.

There was a little social gathering of teachers and pupils in my schoolroom a few days ago, and a resolution was adopted which I will enclose. I will also enclose one of the compositions of the little boy I wrote about in my last. I send it just as it came from his pen at first, without any corrections. He read the story of the Boston Boys remonstrating with Gen. Gage and took it for his subject.257 We had a series of sociables, and the pupils wrote articles and had them copied into a paper called the "Scholars Companion." This was William's first attempt at

\footnotetext{
${ }^{257}$ For a first-hand account of Gen. Thomas Gage's participation in the Revolution see Thomas Gage, Gage's Instructions (The New York Times \& Arno Press, 1971). An overview of the times and Gage's place in it can be found in Fred Anderson's, A People's Army (New York, 1984) and Merrill Jensen, The Founding of a Nation: A History of the American Revolution, 1763-1776 (New York, 1968), Pauline Maier, From Resistance to Revolution: Colonial Radicals and the Development of Opposition to Britain 1765-1776 (New York, 1972).
} 
writing for the paper. I thought I would correct it and let him re-write it, but finally concluded to send it to you just as he wrote it with all its imperfections, and let you judge of a little boy's abilities from it.

Many thanks for your kind invitation which I shall take pleasure in accepting if nothing occurs to prevent me in doing so. The mountains are looking their loveliest on purpose, it seems to me, to increase my regret at leaving them. I haven't heard from Miss Holmes for several months but I suppose she is still in Columbus. When I reach Boston I will see Mr. Hooper and balance our accounts. 258 It seems strange to sever every connection with the Society, and I have experienced so much kindness and consideration at the hands of its members, that I cannot do so without regret. While I live I shall look back upon my connection with them as a very pleasant part of my life. Accept my kindest regards. Yours sincerely

\section{Philena Carkin}

My Dear Mrs. Cheney, Tyngsboro Dec 3d/75

I have been away from home since last Monday and consequently did not receive your letter until tonight. You can well imagine what an unpleasant surprise it gave me to find matters so misrepresented, and I hasten to write at once, and inform you how the matter really stands to the best of my ability.

At the time the new house was built I was not present at any of the meetings that were held to arrange for it by the people of Charlottesville. I went home 
about the $22 d$ of May on account of the illness of my sister who died in July. After her death a brother who was also in consumption failed very rapidly and died the 24th of August. The care and trouble of so much sickness and death in the family prevented my being able to return to the South as easily as usual, and when I did return the house was nearly ready to go into, and the desks were in process of making. If there had been a meeting of the colored people for that purpose, I do not remember of hearing Miss Gardner mention it, and she had the whole management of the matter. Mr. Scott's memory must be at fault, for I never acted as Secretary at any of their meetings. I acted as Treasurer, while the Society lasted there. I regret that I have not the book with me in which I kept my accounts. I think I left it in the care of Mr. Benjamin E. Tonsler, one of my former pupils, and now a teacher in that school. I do not think that the money to purchase the desks was raised by a tax on the pupils, from the fact that they were all made and put in before the school opened, and (I feel quite sure) paid for when done. The tax was not a new thing at the time of the building of the house. It had been levied after the first year in order to relieve the Society from the burden of the incidental expenses of the school, including wood, lights for night meetings, repairs, and the purchase of such articles as were necessary for the use of the schools. Mr. Scott represents it in a very different light. It was always understood by Miss Gardner and myself and also by Miss Holmes, that whatever articles were purchased from the tax money were the property of the Boston Society and if the desks were purchased in that way I should look upon it in the same light. There were one hundred desks at a cost of 2.50 each. In fact twenty of them were made for Miss Gardner's room the year before at a cost of three dollars each. So the whole would amount to even $\$ 250.00$. So the whole tax of one year would but little more than pay for them to say nothing of the 
incidental expenses. I think Miss G. and myself made a great mistake in not keeping the matter entirely in our own hands. But we wished to have them feel that they had an interest in the matter, and deferred so much to their opinions, that some of them became intolerably assuming upon all matters relating to the spending of the school funds in our hands. Miss G. explained to them at last that it belonged to the Community to manage the matter. That by paying a tax of 10 or 15 cts. each child was entitled to all the benefits of the school and that it was for the committee to say through us how the money should be used, always with the understanding that it was to go for the benefit of the school. That it was used in the most economical and judicious manner possible for such a purpose, Miss G. and Miss Holmes can both testify. That a small portion of it went towards paying for the desks is highly probable, but that the furniture of the schools was entirely purchased in the way, and with the understanding that Mr. Scott says is not true. He is simply mistaken.

I wish that his zeal for putting the money for that piece of land into the hands of the rightful owners, were as great as his anxiety to prove some wrong in my management of affairs. As I acted under your authority and by your express orders in selling the furniture, I presume he will have no more to say about it, but I have reason to feel that there is pure malice at the bottom of all he has written and I doubt if there are any (with the exception a small clique, who were opposed to us because we would not be governed by their advice in matters of which we were the best judges) that have said a word of condemnation about the sale. I have letters from there frequently, and have not heard a word of the kind before.

I hope my explanation will prove satisfactory to you, but it came upon me so suddenly and I am in such a state of confusion just now, that I can scarcely collect my mind enough to write. I am now in a transition state, for I expect to 
move to Concord, Mass, the first of the week, and my hands and mind are more than full. I am going to try my fortune there, although my present prospects are not flattering. If Miss Gardner could be consulted she could probably give you a more satisfactory account of the exact manner the money was raised for the desks than I am able to. If you think it necessary I will write to Benjamin for the book in which the school accounts were kept. That which is put down in black and white is better than mere memory sometimes, and if the tax money paid for the desks it will be found in the record made there. I hope Benjamin has not destroyed it. When I came away I put that into his care with some other things and told him I did not know as they would ever be of any importance.

If you think it necessary to write me again upon the subject you can direct to North Chelmsford and the letter will be forwarded if I have moved. It is very annoying to me to have my honesty called in question, particularly from such a source, but as my conscience is clear I shall not let it trouble me much.

Sincerely yours

Philena Carkin

Dear Mrs. Cheney Concord Mass Dec 16th/75

Miss G. has returned Mr. L's letter to me, which I hasten to enclose to you with Miss G. comments upon the same. I have moved down here, and am not fully settled as yet, but I have a girl with me who just came from Charlottesville. 259 ।

${ }^{259}$ Carkin is referring to Margaret Hailstock Terry, the daughter of Nancy and George Hailstock (slaves of Alfred Benson). Terry claimed that when Carkin moved to Concord, Massachusetts, she (Terry) went with Carkin and lived for two years. She attended high school there and stayed until 1877. When Terry returned to Albemarle County she taught at Ivy (2 years), St. John (3 years), Porters [Precint] (5 years), St. John (1 year), Earlysville (5 years), Cismont (6 years), Charlottesville (37 years). She retired from teaching on May 18, 1937 after 59 years of teaching. See Charles L. Perdue, Jr., Thomas E. Barden, and Robert 
asked her in regard to what Mr. L. wrote about people making the sale of the furniture the subject of their animadversion. She said she had never heard one word of it before. Excuse haste from yours sincerely

Philena Carkin

Phillips, Weevils in the Wheat: Interviews with Virginia Ex-Slaves (Charlottesville: University Press of Virginia, 1976), 285-86. 


\section{Appendix I}

\section{The Reminiscences of Philena Carkin ${ }^{260}$}

\section{Chapter First}

The New England Freedmens Aid Society was organized Feb. $7^{\text {th }}, 1862$, having its headquarters in Room 8 Studio Building, Tremont St. Boston, Mass. ${ }^{261}$

Hon. John S. Andrew, the famous war governor of Massachusetts was the first President, and the Society numbered among its members some of the noted people of the time. Miss Hannah E. Stevenson was Secretary of the Teachers Committee when I received my commission as teacher. Other members whose names were well and widely known were Wm. Lloyd Garrison the famous abolitionist, Mrs. Ednah D. Cheney Lucretia Crocker, Thomas W. Higginson, Rev. John Parkman, Hon. Martin Brimmer, and many others whose names were regularly published in the "Freedmen's Record" a small magazine issued (at first) monthly, and later on at irregular intervals for a time until finally its publication was dropped. ${ }^{262}$

\footnotetext{
260“The Reminiscences of Philena Carkin", (Alderman Library, Special Collections, University of Virginia.

${ }_{261}$ Located at the corner of Bromfield and Tremont, The Studio Building was originally the working space for artists. An open, artsy world would co-exist well with the founders of the New England Freedmen's Aid society (NEFAS).

262 John Albion Andrew became known as the "War Governor." Under his direction Massachusetts assumed leadership in the North's military mobilization. When the war began, Massachusetts was prepared to send a full regiment to the defense of Washington, D.C. in April 1861. His papers are at the Massachusetts Historical Society. Henry Greenleaf Pearson, The Life of John Andrew (1904), is an old but standard biography. Richard H. Abbot, Cotton and Capitalism: Boston Merchants and Antislavery Reform, 1854-1868 (1991). Abbot's study provides useful information and contexts bearing on Andrew's career.

Thomas W. Higginson's social activism spanned the antebellum and Progressive eras. Higginson freed, enlisted, and trained former slaves. Though never engaged in a major Civil War
} 


\section{Auxiliary Branch Societies were organized in various towns throughout New}

\section{England. Each Branch Society raising the sum of 500.00 had a special teacher}

assigned to it, with whom the secretary of each society entered into

correspondence upon matters relating to his or her school. ${ }^{263}$ (It was usually her

as women teachers far outnumbered men). ${ }^{264}$ Each teacher was expected to

write, at least one letter, and make out a report of the school, every month to the

parent Society in Boston, and a monthly letter to the Branch Society, and it was

frequently necessary to write two or three in place of one. For a time also they

were expected to report monthly to the Freedmen's Bureau in Washington. In

battle, the well -publicized success of his black troops helped stimulate Union recruitment of African Americans. The minister, reformer, soldier, and author advocated free land and immediate enfranchisement for former slaves and initially supported radical Reconstruction. Higginson's manuscripts are in the Houghton Library, Harvard University.

Ednah Dow Cheney assisted in founding the Boston School of Design for Women, the New England Hospital for Women and Children, The New England Woman's Club, and the Horticultural School for Women. She was also the author of several books: Handbook for American Citizens (1860), Patience (1870), Faithful to the Light and Other Tales (1871), Social Games (1871), and Sally Williams (1873).

The actual founding date is February 4,1862 . The meeting was originally held in the home of Rev. Manning. The Freedmen's Record began publication in January 1865. NEFAS was one of twenty-four secular freedmen's aid groups (excluding federation and local auxiliaries). In addition there were sixteen ecclesiastical freedmen's aid societies between 1862 and 1875 . See Ronald

E. Butchart, Northern Schools, Southern Blacks, and Reconstruction, (Westport, CT: Greenwood Press, 1980), pp 5,7.

${ }^{263}$ In its "Report of the Committee on Teachers" The Freedmen's Record stated that in 1864 at least twenty-eight auxiliary societies had formed and others were in the process of forming. The Daily Records of NEFAS state that "branch societies are invited to become such on these terms: payment of three hundred dollars annually into the Treasury of the Parent Society. On engaging to do that, the Branch Society has a right to select from the list of teachers already employed one person as the special correspondent of that Society, or, if they prefer to do so, to nominate to the Commission on Teachers some person, who if chosen by the Commission would be sent out as Teacher and correspond with their Branch. We merely name $\$ 300$ annually as convenient definiteness for the Societies to begin with; some pay that some twice as much.

${ }^{264}$ Jo Anne Preston "Female aspiration and male ideology: School-teaching in nineteenthcentury New England" Current Issues in Women's History, (1989): 171-82. Richard M. Bernard and Maris A. Vinovskis, "The Female School Teacher in Ante-Bellum Massachusetts" Journal of Social History 10 (1977): 332-45. Approximately one out of five white women in pre-Civil War Massachusetts was a schoolteacher at some time in her life. 
fact, no Freedmens teacher ever had to seek far for an occasion to write a letter to somebody as for somebody.

The main Society paid the salaries of the teachers and their travelling expenses to and from their schools every year. ${ }^{265}$

Buildings for school purposes were usually furnished by the War Department or Freedmen's Bureau...taking any suitable building that had been used for Confederate hospitals or other Confederate purposes. These buildings were used until means could be procured to erect better ones. Money for this purpose was raised in various ways. Contributions from individuals and from Freedmen's Bureau and funds raised by the Freedmen themselves, all helped to swell the amount required, so that after a few years fairly comfortable and convenient buildings were erected in many of the larger cities and towns. Later on when the Societies and Bureau had closed their work the war impoverished towns of the South found these buildings a great help in starting the schools required by their new constitutions. ${ }^{266}$

After a few years the Freedmens Aid Society became a part of a national organization called The Freedmen's Union Commission, and other changes took place, from time to time in that association as well as in the Freedmens Bureau. As fast as the people of the Confederate States showed a disposition to accept

\footnotetext{
${ }^{265}$ The Daily Records of NEFAS stated in February 1865, "The fixed salary of lady teachers in their first year of service is $\$ 20$ per month if they return to a second term of service, the salary from the day of return is $\$ 25$ per month. One month, or six weeks of vacation is considered necessary for each teacher; and it is optional with each whether to receive salary through the vacation, and pay the transportation home, or to have the transportation paid by the Society instead of salary through vacation. The usual salary of gentlemen is $\$ 30$ per month."

${ }^{266}$ Paul Skeels Pierce, A Chapter in the History of Reconstruction: The Freedmen's Bureau and Reconstruction: Reconsiderations. (Fordham University Press, 1999.)
} 
the situation and co-operate with the friends of education in the North, the Society gradually withdrew its teachers from the field, leaving the local school boards to take up and carry on the work they had begun - until finally in the late seventies the entire work was dropped as far as organized northern aid was concerned. The schools, well equipped with necessary furniture and other articles, were from that time, continued and carried on under the auspices of the people of the South. In many instances the native colored teachers were adopted with the schools. This explanation will help to make the situation clear to any one, who, although having heard of the Freedmen's schools never knew how they originated or were supported.

During the nine and a half years that I labored among these people, I met with many and varied experiences of a curious, interesting terrifying or comical nature, and have thought it might not be amiss to put such of these experiences as I can now recall, on paper, for future reference or the possible entertainment of other persons and will begin with my journey to and first appearance in Charlottesville omitting all events this side the Potomac. ${ }^{267}$

\section{Chapter Second}

I wonder if I shall ever forget the absorbing interest with which I looked from the car window as I travelled down the Orange \& Alexandria R.R. the morning of March 2d 1866. The names of the different stations as they were hurled at us by

${ }^{267}$ Karen V. Hansen, A Very Social Time: Crafting community in Antebellum New England. (University of California Press, 1994.) 
the shrill quick voice of the conductor - Brandy Manassas - Rappahannock Orange - Culpepper - Rapidan, etc had each its little separate history that meant so much to me as some one that I knew.

One year of peace had not effaced the outward scars of war. Remnants of old uniforms, old canteens, and the bleaching bones of horses were scattered all about, while here and there stockades and other defensive works still remained. "The Yankees have made a terrible piece of work of this country" said a lady who occupied a seat by my side a portion of the way. ${ }^{268}$

At Gordonsville $e^{269}$ the cars stopped half an hour for refreshments or some other cause, and it was curious to see the crowd of colored men, women, and children who seemed to spring out of the ground, as it were, each individual bearing aloft a tray of eatables. They flicked about the car windows vieing with each other in their efforts to secure the attention of the passengers. "Have a snack!" Have a snack!" "Nice fresh snack!" came from many pairs of lips at once, while as many pairs of eyes threw beseeching glances upon the faces of the passengers inside. I succumbed to the combined entreaty of lips and eyes, and invested in-apiese-of some fried chicken, daintily couched upon a piece of bread, although I had brought a well filled lunch basket with me, the contents of which were not as yet exhausted. The chicken proved quite palatable, but its accessory, the bread, belonged to that unfortunate class of objects whose

\footnotetext{
${ }^{268}$ Nina Silber, The Romance of Reunion: Northerners and the South, 1865-1900 (Chapel Hill: University of North Carolina Press, 1993). Catherine Clinton \& Nina Silber, editors, Divided Houses: Gender and the Civil War (Oxford University Press, 1992).

${ }^{269}$ William H. B. Thomas, Gordonsville, Virginia: Historic Crossroads Town (McClure Press, 1954).
} 
appearance is not such as to create a desire for a more intimate acquaintance so, as the train moved on I cast it forth, heedless as to whether it fell "upon the waters" as otherwise. If it did Heaven it may not "return" even "after many days."270

One source of constant anxiety to me was that at so many places where we stopped, there would be no station or other house in sight. Often the only sign of life would be a man standing upon an uncovered platform, a saddle-horse tied to a post, and two or three barrels and boxes doing duty for civilization. I thought if Charlottesville should be like that what was I to do with my two trunks and no conveyance to take me anywhere. However as the train approached my destination there grew to be a more decidedly inhabited look about the country, and finally we steamed into Charlottesville, amid the shouts of hack drivers and posters. In something of a spirit of mischief I addressed myself to several white ladies asking where I could find Miss Anna Gardner, she being the teacher who had preceded me by several months, and with whom I was to be associated. Each one whom I addressed drew back with a cold stare and the reply "No, I don't know her," so I gained nothing by my questions but the curious, and not over friendly regard of the crowd assembled at the station. I was about to pursue my inquiries among the colored people where I knew I should get the information I required when I met another lady to whom I put my question. She, more courteous than the others pointed out an omnibus which she told me would take me where I wished to go, and even spoke to the driver for me. I learned her

\footnotetext{
270 "Cast your bread upon the water, for after many days you will find it again. Ecclesiastes chapter 11, verse 1, New International Version.
} 
name afterwards, but regret to say I have forgotten it, but I have not forgotten her exceptional politeness. $^{271}$

Upon arriving at my destination I was deposited upon the broad piazza of an immense brick building the exterior of which struck me as being in an advanced state of dilapidation. A wide hall, the doors of which stood open passed through the centre terminating in a door at the rear, with a corridor running from midway to the left. At the right of the hall the whole lower floor formed one large room. At the left were four square rooms. I do not suppose I studied out this fact immediately upon entering, but having pointed out the feature of the hall, enter into this further bit of information. ${ }^{272}$

The only person in sight was a blue-coated soldier facing the hall with a gun upon his shoulder. I was about to go forward and address him, when an officer stepped out of a door at the left. I explained my business to him, and he kindly sent a message to Miss Gardner, who was in school at that hour, to inform her of my arrival, and courteously invited me to dine with his family who were quartered there. This officer was Major Head - a man with many good qualities and one great failing - an occasional over indulgence in strong drink. ${ }^{273}$ While awaiting

\footnotetext{
${ }^{271}$ John Hammond Moore, Albemarle: Jefferson's County, 1727-1976 ((Albemarle County Historical Society, 1976).

272 Ibid. pp 173, 203, 216, 227, 231-32. K. Edward Lay, The Architecture of Jefferson Country. 273 In May 1865 Lieutenant Colonel Franklin A. Stratton arrived and reported, "Not many disorders have come to my notice throughout the country, but there is much need of a military post at this place to preserve order and to protect the citizens from small bands of mauraders and robbers investing various localities between here and the Blue Ridge." In June 1866 Stratton was replaced by Captain William L. Tidball, who served both as military commander and district supervisor of the Bureau of Freedmen, Refugees, and Abandoned Lands. Tidball was highly thought and the Chronicle noted his departure, "no officer could have conducted himself with more fairness, kindness, and tact than he has exhibited in the difficult position he has occupied here...he has been truly a mediator and peacemaker between the blacks and whites." See Webb, "Charlottesville and Albemarle County, 1865-1900" (Ph.D. dissertation, University of
} 
dinner Miss Gardner came in. Although this was our first meeting it seemed as if we were old acquaintances, as we were both Massachusetts women, and met upon what then seemed the soil of the enemy, and amid such formidable surroundings. And so began a friendship which lasted as Long as she lived.

After dinner Major Head and Miss Gardner held a council, and a room was given me on the second floor which had been occupied by a young man - Mr. Woodman - a teacher from Newburyport Mass. He had occupied the room but a short time and then gone to board in a family near by named Musgrove. Mr. Musgrove was also a teacher. ${ }^{274}$

The room was bare of furniture except a bedstead made of short pieces of timber a rough frame to put a bed on. The straw bed used by Mr. W. was still there. There was also a primitive sort of a wash stand with the bowl and pitcher of the previous occupant.

Major Head sent his orderly for my trunks and when they arrived, Miss Gardner directed her woman to build a fire in the fireplace which stretched across a corner of the room, and brought me in a wooden chair, a small square table of the same rude style as the washstand and a short bench. I unpacked my trunks, made up my bed, having brought bedding for the purpose, hung up my dresses on nails that were driven in the wall, put some books and small articles on the broad mantle piece and sat down feeling quite at home. I had come out

Virginia, 1965). After Tidball's tenure in Charlottesville, Lieutenant A. F. Higgs arrived followed by Lieutenant Town. Thanks are due to Thomas Riedel for his research in this area.

${ }^{274} \mathrm{Mr}$. Woodman, the young male teacher might have been recommended to the position by way of Reverend Higginson who was the minister for a brief time of the First Religious Society (Unitarian) in Newburyport. Robert A. Musgrove was also a merchant on West Main Street. 
expecting rough living and should have been truly disappointed had I found home comforts and luxuries.

The next day I went with Miss Gardner to her school which was kept in a large wooden building erected by the Confederates for a hospital. It was 140 feet long by some 70 feet in width and two stories high. This served us as a school building for three or four years, and for a portion of that time we had living rooms fitted up for ourselves in the second story.

Here we had a school of four grades numbering something more than two hundred pupils, ranging in age from six to twenty five or thirty years, and of every shade of color from the purest blonde to the duskiest black. I even had for a time in my day school two women who were past sixty years of age, for old as well as young flocked to us hungering and thirsting for the knowledge which had been denied to them heretofore. Poor souls! It was hard to refuse any but our conveniences for teaching were limited.

I opened an evening school where I instructed forty-five adults, three evenings in a week, and we encouraged our more advanced pupils to impart what they learned in school to their less favored friends; and this was the way the work began in Charlottesville.

When at the end of nine and a half years I bade a final adieu to the scene of so much pleasant labor, I could hardly realize that this was the place were we had found a race of people so ignorant that they imagined "a right smart education" could be acquired by a few weeks study. Their mistakes in this matter were both ludicrous and pathetic. Said one man, who by this native shrewdness 
and industry had acquired some little property, "I shall take Sarah (his daughter) out of school. I have been sending her to Miss Anna due six months and she don't know 'nuff to do my law business for me." But old and young learned, in time, that an education could not be acquired in six months or six years, and as time sped on the mists were lifted in a measure from their poor darkened eyes, and they began to realize that freedom meant ownership of themselves with the privilege of choosing their own occupations - not as many of them first thought, exemption from all labor.

\section{Chapter Third}

Charlottesville, va

Charlottesville is on the Rivanna river, a branch of the James, and is about 118 miles southwest of Washington D.C. and 90 miles northwest of Richmond. The main range of the Blue Ridge mountains is some 20 miles northwest of the town but there are scattering spurs of this range all about the place. The Ragged Mts, as they are called lie a little to the west or southwest while Monticello and some other eminences are near by the town.

The scenery about the place is magnificent beyond description with the long blue line of the mountains in the distance, and the wooded giant hills near by. Sometimes in the early morning the sun would pour a flood of light upon the green upper portion of the mountain nearest us, and tinge with a variety of colores the clouds as mists hovered about one third of the way below the 
summit. Always beautiful, at such times its charms would be enhanced a hundred fold. No further words are needed for one to understand that Charlottesville, as far as locality is concerned must in the nature of things be a wonderfully beautiful place.

The soil is of a reddish clay which during a rain forms into a clinging kind of mud, very unpleasant to travel through. During the years I was in the place there were very few street crossings such as are accustomed to in northern towns. Instead they had what they called stepping stones. - that is stones of varying shape and size placed at irregular distances across the street. One needed to be an expert gymnast to accomplish the crossing feat in safety. Should he happen to slip from the top of one of these curious conveniences, many of which would be round and smooth on the upper side, he would find himself liberally bespattered with a solution of the "sacred soil of Virginia." This same soil, however, was rich in nutriment for vegetation as the fields of corn, wheat, tobacco etc attested.

The climate of Charlottesville is, of course much milder than that of New England. Still there was much cold weather in the winters, and the mercury would sometimes fall below the zero mark, and there would be snowfalls of considerable depth. But the snow never lasted long - scarcely as long as the mud it helped to form, and Spring greeted us quite early. High winds were frequent, and sometimes terrifying. We never remained through the hottest season - always coming north the last of June or first of July. 
The incorporated town, or rather city of Charlottesville numbered some 4000 inhabitants in the late sixties. It was the county seat of Albemarle. Outside the town limits was a considerable area of unincorporated land in Albemarle Co. belonging to Charlottesville township. Our school was outside the corporation, as was also the University of Va.

A stranger visiting Charlottesville was likely to be impressed by the sight of the liberal handiwork of Nature, and the very meagre assistance she had received from man. For a town of its size, the place was singularly destitute of municipal conveniences. There was no adequate water supply, wells being the sole dependence in this respect, and one well often had to serve for several families, consequently instead of being placed conveniently near one house they were usually arranged so to be inconvenient for all. The water was very good however, and was brought into the houses in pails or pitchers by servants, who often carried these vessels on their heads. I have seen the woman who worked for us bring three full pails of water at one time - one on her head and one in each hand. I asked her once if she could manage to carry one on each shoulder too.

Aside from the lack of water I think there was no fire company or any kind of fire apparatus in the town, so any building that caught fire might well be considered as doomed, and it is really a matter of great surprise that during the years that I was there, there was never a serious conflagration. A good many isolated buildings were burned, but there were no fires on a large scale. In case of a fire the citizens turned to and did what they could in carrying water and other 
work necessary to subdue the flames or save property, but it was unorganized work and very inefficient.

I never learned whether there was any regular system for taking care of the streets, but all the highways in and about the town were in a very poor condition. Outside the more populous part of the town the side walks were usually of plank, and always more or less broken and dilapidated, and the unpaved streets after a heavy rain would be a well of sticky mud. Wheels would sometimes sink nearly to their hubs, and the poor horses had a hard time dragging themselves and their loads through it.

Sometimes the country roads would be impassible for days at a time, and there would be a famine in such articles as fuel, fresh meat, poultry, butter eggs and milk. I remember one time when we could get no wood on account of the state of the roads caused by a prolonged rainstorm, and should have suffered for want of a fire had not some of our boys brought us wood from their homes, in bags slung over their shoulders. There was probably a dealer in wood and coal in the town, but the business must have been on a small scale, and when we needed fuel we would have some of the older boys watch for a load of wood coming in from the country - make a bargain for it, and have it put in the place of storage. To a New Englander this seems rather a hap-hazard way of getting supplies, but it was the best we could do at that time.

The markets also seemed to depend upon the local country supplies for meat, vegetables, butter, eggs, etc. We could rarely get good beef, and the flesh of the scavenger swine had no temptation for us, but the mutton, lamb, and poultry 
were excellent. We also had an occasional meal of vinison, as well as some of the smaller wild game, as squirrels, pheasants, etc. I often regret that I made no effort to try a bit of possum, but I did not think much about it while there. When I first went out it was hard to get butter fit to eat, but after a while we learned to watch for country dealers, and get a supply from them. In those early years all provisions were very high. I do not recall the price of butter, but I remember I paid 25 cts. a pound for granulated sugar, and 40 cents for raisins. Milk was ten cents a quart, and very blue and creamless at that. I could get no salt port such as we have in the north - everything was bacon. Baked beans of New England style was unknown. One of the colored women heard me bemoan the fact that I could have no baked beans, so she set herself to work to prepare some for me. first she boiled the beans to a mush and rubbed them through a strainer, then formed them into small round cakes and baked them. They were quite palatable but didn't seem much like the real article. A little experience with Virginia beans showed me that many of them were tenanted by a small black bug. This was not appetizing so I learned to carry beans, salt pork and [unclear] as well as many other articles of food with me and after that I had my regular dish of New England baked beans.

I did a good deal of my own cooking as the Virginia methods were too rich to be healthful for ones regular diet, but the cooks were masters of the art in their own way, and I shall never forget their delicious fried chicken and Sally Lunns. ${ }^{275}$

\footnotetext{
${ }^{275}$ Sally Lunns are a bread-like cake.
} 
A good deal of their cooking was done by an old fashioned fireplace. For baking they used a large, round, flat kettle with a tight-fitting cover, which they called an oven. As I never witnessed the process of baking in it, I do not know how it was managed, but however it was done they usually made a success of their work.

Their were quite a number of grocerys and dry goods stores in town. - two or three druggists and about the same number of Jewellers. There was no large city nearer than Richmond so people depended largely upon the local merchants. I never heard that there was any law regulating the sale of liquor, so every grocery was a liquor store as well. The drinking habit was almost universal, and persons in a state of beastly intoxication a common sight on the street. There was one policeman, called the Town Sergeant who was supposed to keep order in the place, and I think there were a few others detailed for extra duty, but street fights and rowdyism prevailed, and even murders were so common as to have lost the power of inspiring the horror they would in one of our northern towns of like size. All this seems the more remarkable when we remember that Charlottesville is a town of the highest culture and great refinement. In trying to account for this extraordinary state of things, one must remember that many different causes have combined to effect this difference. The very foundations of Virginia and New England were as different as possible. There could be little in common between the earnest, sober, hardworking Puritans of the northern section, and the gay, idle, impecunious and extravagant younger sons of noblemen who settled Virginia. The climatic influences were different, and more 
than all, the habits of thought and feeling engendered by slavery tended to develope a recklessness of action among the people which culture scarcely seemed to soften to any great extent.

The town was not protected from epidemics of sickness by any very rigid sanitary measures. I understood that there was a law protecting buzzards, as they were the necessary scavengers of the streets, and byways of the town. Dead dogs, cats, and other creatures were thrown on to some vacant lot for these loathsome birds to feast upon. There was very little pretense of effort to encourage public cleanliness, and all sorts of refuse matter lay about unheeded. During my first years there cattle and pigs roamed the streets at will. Often the only subsistence of the cow of some poor person, was what she gathered at the roadside, and on open unoccupied lots. The swine were the efficient assistants of the buzzards, as scavengers.

The people of the place were professedly religious and there were a goodly number of churches of the various Orthodox denominations - Presbyterians Methodists, Baptists, Carmelites, Episcopalians and a sect called Christians, and I think there was a Jewish synagogue, as there were a good many Jews in the town.

Our position as teachers of the Freedmen was such as to shut us out of the sympathy and society of the white people generally, so I can say but little in regard to them socially, except that I have reason to think they were, in their own way, very kind and charming people. A few-a very few met us with some degree of cordiality, and we found them very agreeable, but we went there 
immediately after the close of the war, and it was too soon for us to expect the feeling of bitterness to have died out. We ourselves had suffered and carried the bitterness of that suffering in our own souls, but these people had witnessed the death of all they had hoped for and fought for. - and we were Yankees. It could not have been easy for them to look upon us as friends so soon particularly in view of the work we went there to do, which, to their minds was not a friendly one.

There were no public schools in Charlottesville when I went there, but these came in with the new state constitution. There was a young ladies school, or seminary, but if I every heard how it was managed I have forgotten. There was a school for boys taught by a Mr. Williams. The school was within a few rods of our own, and as I think of it now it seems remarkable that there was never a clash between the boys of the two schools. There were probably other private schools in the place, but I either never heard of them, or have forgotten them.

I never saw any snuffdipping while there, although tobacco in other forms was universally used by the men, and not unfrequently by the women. It was quite common for little boys to both smoke and chew tobacco, and it was necessary for us to take a firm stand against its use in school, or the boys would have chewed during school hours. However when they found it must be no tobacco, or no school they submitted with such grace as they could.

Another rather alarming habit of the male population was carrying pistols. Even the colored boys soon acquired the habit, and several times I found it necessary to take pistols from boys who had brought them to school. A stranger 
coming into my schoolroom might have thought I had to resort to desperate measures to govern my school seeing one or two revolvers lying on my table. But the boys even learned that pistols like tobacco were not allowed in school, and I ceased to be annoyed by them which was no small relief.

A little way to the west of Charlottesville, among the Ragged Mts. lived a class of people known as "poor whites." They were exactly as one sees them represented in pictures or on the stage - long, lank, with straight unkempt locks, and nondescript clothes. I would often see a whole family - man, woman, and several children come up the railroad track together on a Saturday morning each with a pail of meagre looking strawberries to sell. These they would dispose of for a small sum, and lay out the proceeds in a little bacon and corn meal, the larger part going for whiskey and tobacco. If we walked down the street a little later in the day we would be likely to find them sitting contentedly on the curbstone, smoking their pipes and talking over the incidents of the day. Thus the whole family would spend the entire day in doing what one bright boy could have done in half the time, except, perhaps the amount of smoking accomplished. I was told that some of these people lived in a kind of hut with only the bare earth for a floor, and that they generously shared these primitive accommodations with their pigs and fowls, as well as their dogs.

There seemed to be no very extensive manufacturer in or about Charlottesville. All that I can now recall are the Charlottesville Woolen Mills (the extent of which I never learned), and a brick yard which occupied the lot next our school. The land being a red clay was particularly suited to this purpose. 
The works were extensive - there being only a small number of kilns. I fancy all the bricks made there found a market in the town or vicinity but I may be mistaken.

Travelling about the vicinity was largely done on horseback, two or three persons often riding together on one horse. I once saw a man riding with a harrow fastened in some way upon the back of the horse behind him. It was probably much easier getting over the rough roads on horse back than in a carriage. An omnibus used to run between the town and the University with some attempt at regularity.

Railroad accommodations were not very good at that time. The Orange \& Alexandria R.R. extended from Washington through the town to Lynchburg. (How much, if any farther, I do not know) and the Virginia Central from Richmond through Charlottesville to Staunton - perhaps farther. These roads formed a junction near our school, and I think used the same track to Gordonsville where the lines separated again. There were only two passenger trains per day each way on either road, passing through both ways near noon and midnight.

The dwelling houses, as far as they came under my observation were not generally constructed with an eye to convenience in the same degree as houses of the same class in the north. The kitchens were usually small separate buildings in the rear of the main house, and very little thought seemed to have been given to the idea of making one's labors light. That would naturally be a remote consideration to people who had no practical knowledge of household 
labor themselves, and who with their numerous slaves could see no occasion for labor saving conveniences; and so the work was done, in what seemed to us a very hard as well as slip-shod way.

There was no law for the protection of dumb animals, and there seemed to be a deplorable lack of feeling in regard to their sufferings from the thoughtlessness and cruelty of their owners. No doubt there were many of the citizens whose feelings like our own were outraged by the barbarities inflicted upon the lower creatures, but there was little that could be done, with no law, and no visible public sentiment on the side of kindness. Cows would wander about on the outskirts of the town all winter, nibbling the dead grass by the wayside or getting a slender feast from the sides of an occasional haystack. Mere skeletons, they seemed scarcely able to drag themselves about. - without shelter in the coldest storms of winter. Spring must have seemed doubly beautiful to them. Horses were over loaded, over driven and beaten without the slightest show of mercy. Slavery had hardened the hearts of both master and slave, and all animals had to suffer in consequence. Of course there were exceptions, but brutality was such an ever present habit that we came to regard it as the hard unfailing rule. It was the custom in Charlottesville to keep a great many dogs.-pa rtly for hunting and partly for protection from marauders. If a man were in moderate circumstances he might content himself with two or three, but if he were very poor indeed he would perhaps have five or six. These dogs were usually ferocious and when one had occasion to call at a house he was likely to be met by three or four yelping, snarling canines. People usually waited at the gate for 
some one to come and call the creatures off, but never having been accustomed to savage dogs, I at first paid no attention to this apparent ferocity and would go right on up to the door through the snarling pack, supposing that this was their eccentric way of welcoming a stranger. I wonder now that I am here to tell of it, but I really had no idea that they were dangerous until I witnessed the surprise of people at what they looked upon as my temerity. Perhaps the fact that I showed no fear, held the savage brutes in awe.

Through the early years of the Civil War, Charlottesville escaped the ravages of the marching armies, and became a rendezvous for the sick and wounded. The spacious buildings of the University of Va. were put to hospital uses along with the three storied Mudwall or Delevan House, which was our home for a time. There were also five or six rough wooden hospital buildings erected near by, the largest of which was $140 \mathrm{ft}$ long by about 70 feet in width and two stories high. The sick and wounded Confederate soldiers and a few Union prisoners in like condition were cared for here. Among the latter was Major Savage, a brother of the wife of Prof. Wm. B. Rogers who with some other 13 or 14 Union prisoners died here, and were buried in the cemetary attached to the University grounds where, in after years we would go occasionally to lay our offering of flowers in memory of those whose graves were beyond our reach. ${ }^{276}$ Later on their remains were removed to the national cemetery at Culpepper. Many were the

\footnotetext{
${ }^{276}$ James Savage, Jr., was the only son of the Honorable James Savage of Boston, Massachusetts. He was born April 21, 1832, and graduated from Harvard College in 1854. He died in Charlottesville on October 22, 1862, from wounds he sustained at the battle of Cedar Mountain on August 9, 1862. Originally buried at the university Cemetery, his casket as well as several other Union soldiers was then moved to Culpeper. See Gayle Schulman's article in MACH, 55 (1997), 92.
} 
delicacies these poor Union soldiers received from the hands of the colored people, conveyed to them in various secret ways.

When Sheridan made his famous raid through this part of Virginia the people of this place got their first taste of what war meant at their own doors. As there were no troops to oppose them the town escaped the ruin which is the usual fate of places where battles are fought. Sheridan soon moved on, and many of the slaves followed in the wake of the army - refugees they called it.

Among the most noted men of Charlottesville was Judge Alexander Rives, whose residence-Carlton-was on the outskirts of the town. If my memory serves me correctly he was a brother of the Hon. Wm. C. Rives at one time minister to France, and early lover of Eugenie who afterward married Napoleon, III. Judge Rives was a cultured high-bred gentleman - one of whom Virginia could well afford to befriend. I understand from the colored woman who had been the nurse of his children that he graduated from Harvard College. ${ }^{277} \mathrm{He}$ was a large slave holder, and keen sighted enough to see that secession meant the death of this peculiar institution, consequently he cast his vote against the measure. This raised the ire of the hot-blooded young secession element, and a part of young men - presumably mostly students from the University-went out

\footnotetext{
${ }^{277}$ Isabella Gibbons most likely worked in the household of the prominent Albemarle slaveholding family, Professor Francis H. Smith (1829-1928). Although enslaved people could not legally marry, Isabella and William Gibbons did form a union and had several children. William Gibbons later became a licentiate or lay preacher to the Delavan Church. In 1869 he was called to Washington, D. C. where he pastored Zion Baptist, a large church, for eighteen years. Reverend Gibbons died at the age of 61 years old on June 28, 1886. The Gibbons' had several daughters named Maria, Alice, and Bella. One of their sons, William P. Gibbons, became a minister, like his father. Another son, John West, is also believed to be one of Isabella Gibbons' offspring. Isabella worked as a nurse and tended soldiers at the University of Virginia as early as July 1862. One $f$ the men she nursed was Major James Savage, Jr., Lieutenant Colonel of the $2^{\text {nd }}$ Regiment, Massachusetts Volunteers.
} 
to his place one night, and cut off the tops of two rows of young shade trees which had recently been planted on both sides of the long avenue leading up his house. It is gratifying to be able to say that this act of vandalism failed in its object as the cutting only served to make them take on a more symmetrical form.

However Judge Rives might oppose secession he was a true Virginian rather than a true American, and went with his state. After the war was over he wisely accepted the situation and gave his hearty support to the U.S. government. It was my good fortune to hear him deliver an eloquent address before the delegates to the Constitutional Convention at Richmond. He became one of the trustees of the Hampton Normal School at the solicitation of Gen. Armstrong who came to Charlottesville for that purpose, and called on us while there. He also became one of the trustees of our school at Charlottesville, and in doing so became a member of the same board as one of his ex-slaves Paul Lewis, his one time body servant. ${ }^{278}$

\section{Another noted citizen was Col. Jefferson Randolph, a grandson of Thomas} Jefferson. He with several other gentlemen of the place addressed the colored people on the grounds in front of our school house previous to the election of delegates to the constitutional convention. He was a white haired old man at this

\footnotetext{
${ }^{278}$ Judge Alexander Rives, the son of Robert and Margaret Cabell Rives was admitted to the bar in 1829. He became a member of both houses of the Legislature, and of Congress, and following that he was appointed Judge of the U.S. Court for the western district of Virginia. He was an active member of the public school board Of Albemarle County before he died in 1885.

In the 1870 Census Paul Lewis (age 37) listed himself as a teacher and his wife Margaret (age 25) classified herself as a housekeeper. They valued their real estate at $\$ 600$. Their children were: Augusta (11), Pleasant (9), Lewisa (6), and Pearl (3). All but their youngest child attended school. Another child, Eliza Clarkson (12) lived with them and also attended school. Lewis was a native of Virginia and had worked as a teacher as early as 1868. His primary level school, classified as a class, was called the John Brown School.
} 
time and began his address by telling the colored people that many years before he had favored emancipation. Perhaps the words of his distinguished wise grandfather rang in his ears. "I tremble for my country when I remember that God is just."

There were several other men of considerable note of whom I can now recall only the names, like Judge Cochrane, Profs. Miner and McGuffy of the University and many whose names even have escaped me.

I have tried to make as correct and faithful a picture as possible of Charlottesville as I knew it, and if some things seem exaggerated I can only say that I have written without prejudice, and have told all things as I found them to the best of my recollection. I often regret that I took no notes when there-but never dreamed I should have occasion to use them, and was too much absorbed in my daily work to give any thought to such matters.

\section{Chapter Fourth}

Monticello

Monticello, the mountain upon which stood the home of Thomas Jefferson was one and a half or possibly two miles from the centre of the town of Charlottesville, and a little farther from our school

We made several visits to the place during the years we were there - visits that have left a vivid impression of the magnificent beauty of the place, and of the terrible condition of the road we had to travel to reach it. Visitors must have recalled the old tune "Jordans a hard road to travel" when making a trip over this 
particular piece of highway. Before reaching the foot of the mountain, whether by the regular road or by driving through the grounds of "Carlton" Judge Rives place it was necessary to ford the river, as there was no bridge at the time. This feat was accomplished with much splashing and jerking. The waters being very muddy like all streams in that part of Virginia it was necessary that the uninitiated should exercise a wholesome faith in horse, driver and vehicle in order to insure his own comfort when it would seem sometimes as if the horse was about to disappear altogether. The ascent of the mountain was by a road, than which nothing could possibly be worse. When I remember the rocks, stumps and gullies that filled what was by courtesy called the road, I wonder that horses could have dragged us up, or that any vehicle could have been made that would stand such a strain. But our courage was always equal to the venture and the object attained justified our efforts. The view from the summit was magnificent beyond description. In one direction was the long level line of the horizon with nothing to obstruct the vision. Below us the town and all about waving fields of grain with the silver thread of the Rivanna winding through the green fields and meadows. No Eden could be fairer. The house is a stately old mansion. Through the front door we entered a hall octagonal or hexagonal in form (I cannot be sure which but think it was a hexagon). A clock over the front door showed a dial both outside and inside: the weights hanging on each side of the door in the hall. A gallery ran around a portion of the hall at the height of the second floor. On a high shelf at the left of the door stood a bust of Voltaire. ${ }^{279}$

${ }^{279}$ Carkin first wrote and struck out the word "right" before inserting the word "left." 
The floor of the hall was a wonderful piece of work. A hexagonal figure of some dark wood, nine or ten inches in diameter, framed by very light wood possibly two inches wide the whole put together so nicely, that it seemed like one wide board very highly polished. This was the work of one of his slaves and is a marvel of beauty and perfection. It was into this hall that the British Col. Tarleton rode his horse when he came with his troopers to capture Jefferson; who discovered their approach in season to escape into the mountain by a secret passage. We were told that the marks of his horses' shoes could be found on the floor of the hall but we failed to discover them. We visited the parlor and library and went up stairs. Such curious, narrow, wholly enclosed winding flights of stairs! It would be impossible to take a large modern chair up over them. The bedrooms were very peculiar. Each had an alcove as large as a full sized bed, with slats of wood fitted in lengthwise upon which the bed was made, so no bedsteads were required and no one could get to the bed except from the front. The windows swung in and out as transomes sometimes do. There seemed but little to see that had belonged to the distinguished owner. In a chamber we were shown the chair he used after his health failed - a plain wooden rocker. The slave quarters consisted of long low building divided into small compartments, neither so comfortable or cheerful as we should provide for our cattle. The grounds about the house must have been beautiful when Jefferson was there to care for them. A little way from the summit of the mountain is the family burial place, which we visited, and from which I once brought away a root of very beautiful ivy, and one of periwinkle and sent to a friend, who planted them and they flourished for 
years. At that time Jeffersons monument had suffered much at the hands of vandal sight-seers and was dreadfully defaced by pieces of the tone being chipped off to carry away as relics. I hope the place is better cared for now, and that it has been made more convenient for tourists to reach the home of one of Virginia's greatest men. It would seem as if it might be made interesting by putting the place in charge of some one capable of giving information on many points, which the curious visitor of my day had to content himself to do without. It would be of especial interest to strangers to be shown the avenue through which Jefferson escaped the clutches of Tarleton as well as many other points of interest, but even as I saw it I found it very interesting - so interesting that after the lapse of thirty years it stands as a vivid picture in my memory, and I would give much to repeat the tour and see through my age-dimmed vision that which charmed the clear eyes of my younger days.

\section{Chapter Fifth.}

The University of Virginia

I regret that I did not learn in what years this University was founded - only that it was the offspring of the brain of Thomas Jefferson so it must have been very late in the 18 or early in the 19 century. ${ }^{280}$ It is, I should say, about three fourths of a mile from the centre of Charlottesville on the Virginia Central R.R.

\footnotetext{
${ }^{280}$ Jefferson established the University of Virginia in 1819 when he secured passage of a charter for the University. It was forty years after he had proposed his comprehensive plan for public education.
} 
near its junction with the Orange \& Alexandria R.R. The college grounds are enclosed by the main buildings at one end from the right and left sides of which extend the dormitories of the students. So many years have passed since I visited the place that my recollections of it all are very dim. I remember that the students had formed themselves into two societies - the Washington Society and the Jefferson Society. Each society had its own hall. In Jefferson hall I think, there was a fine copy of Raphaels' "School of Athens," each figure in the group being life size. A fine statue of Jefferson was placed in position during the years I was there. An excellent whispering gallery was a feature of one of the rooms of the building.

Jeffersons whole soul went into the planning and making of this University, and he watched its material progress with the closest scrutiny and deepest anxiety. I am afraid he would have found less satisfaction in the mental and moral progress of the students, had he come upon the scene about a century later. This is only a whisper however, and detracts nothing from the moral value of his efforts to establish a model University.

Young men from all parts of the South, and some parts of the North come here as students. Any one living near the University would soon become impressed with the idea that it was a pretty wild and reckless crowd judging from appearances Probably the larger parts were orderly and studious but the disorderly and reckless elements are always more in evidence from the very fact of their disorderliness, and our experience of them as neighbors did not tend to raise them in our estimation as a whole. Woe to the unfortunate individual, be he 
professor or citizen of the town who in any way gained the ill will of one of these students. With faces masked, and torches made of brooms dipped in tar and lighted, they would march to his house to the music of tin drums and tin horns, and surrounding the building make night hideous, as only yelling demons can. The victim might not always escape with only a Calithump. Injury to person and property were not uncommon, and murder not unknown. As we lived about half way between the town and the University we were naturally objects of some interest to them, although they never treated us to a Calithump. During the first few years of our work there, they probably felt that we were in a way under the protection of the national government, a nd in later years they had become accustomed to our work there so we were never seriously disturbed. I do not mean by this that we were wholly ignored, for they often paid us the compliment of threats, or broke our windows or showed us some other delicate attention of a similar nature. At one time they had a habit of climbing upon the top of the cars of the Va. Central trains that stopped at the University station. With their pockets filled with stones, as the train moved on they would throw these missiles right and left as they pleased. The train passed within a rod of our school building, and they would sometimes make a target of our windows two or three times breaking every pane of glass in a window. This was expensive as well as unpleasant for us. One Saturday when I heard the train coming I seated myself quietly at my open window facing the track, book in hand. As the train drew near I could see that every one had a stone ready. I looked up from my book innocently as if it had never occurred to me that they would do so brutal a thing 
as to throw - and they didn't! Disquieted with their conduct, the railroad company refused to allow the trains to stop at the University, after that so when it was necessary for them to take the cars, they were compelled to go down town to do so.

On the night that the news was received of the first election of Gen. Grant to the Presidency I was roused from a sound sleep by the crashing of stones through the window of my sitting room. A party of students had been down town to get the election returns, and, furious at learning of the Republican success vented their spite in that way, making the act energetic by a vigorous accompaniment of oaths and imprecations - as if we could have prevented the election of Grant had we wished to do so - which we didn't. ${ }^{281}$ It was fortunate for me that my bedroom was in the rear of my sitting room. Had it been otherwise the consequences might have been serious.

During the years when the Ku Klux were causing so much disturbance in the South, they once left a picture of a coffin with the regulation mark K. K. K. upon it at our door, and they made various efforts to annoy us - perhaps with a view of frightening us away; not considering, perhaps, that had we been timid and easily frightened we should not have gone in the first place. I have mentioned here two or three instances of their exhibition of ill will toward us as Yankees, and toward our work of educating the freed people, as specimens of some of the annoyances to which we were occasionally subjected, but it would lengthen this

\footnotetext{
281 Ulysses S. Grant was elected as a Republican to two terms as president (1869-1877). His administrations were marred indecisive leadership as well as corruption and an inconsistent policy on southern Reconstruction.
} 
chapter unnecessarily to recount them all, even if I could remember them. They formed a unique part of our experience there and I have introduced enough to make the whole easily comprehended.

On a few occasions some of the Professors or students visited our schools. This we were always glad to have them do, hoping in this way to arouse an interest in our work there, and we often had a good deal of satisfaction in hearing through various sources, that they had been very favorably impressed with what they had seen and heard. One of the Professors even complimented our work highly in an article published in the local paper. Coming from such a source it meant a good deal to us.

One day - late in the afternoon - I was surprised by the entrance of two young men who walked up to my platform, their faces beaming with smiles and introduced themselves in this wise, "We are students from the University. We study Moral Philosophy under Prof. McGuffey, and we are anxious to know something of the working of your school system." This was all so sudden, and they were so breezy and so sunny, that I found myself shaking hands with them without any volition on my part, and giving them a smiling welcome, before I fully realized their presence. I had seats placed for them and went on with the lesson that was in progress when they entered to which they listened with every appearance of interest. I strongly suspected that the interest was all on the surface, but if so they were good actors, and commended what they heard very highly, and rising they bowed themselves out saying they wished to visit the other rooms. It was evident they had been drinking a little, although not what one 
could call the worse for liquor - only excessively polite. When they went to Miss Gardners room it was quite late in P.M. and she had already dismissed a class of boys, who had stopped in the vicinity of the school house for a game of ball. Soon after they left my room it was time for me to close school, and some of my boys told those of Miss Gardners who were outside that two drunken students had gone into her school-room upon which six or seven of her larger boys grown young men - sent for her to come to the door, and volunteered to remove the students if she wished them to do so. She thanked the boys but assured them that she was very glad to have the young men visit the school, as they were perfectly well behaved and exceptionally intelligent. She took a good deal of pains to show them what her pupils could do, and they confessed they were much surprised as well as pleased. After my school was dismissed, I remained in the room while some of the girls put it in order for the next day. I stood upon the platform with one hand full of tiny flags, which had been used in an entertainment the night before, and which I had gathered from the desks where they had been left, when the students coming from Miss Gardners room were about to pass my door. Seeing me they came in to tell how well they had been entertained there. Then one of them said, referring to the flags in my hand "Shall we take one?" I replied "Certainly" when each took a flag and stuck in the lapel of his coat, saying as they did so "We will wear them in remembrance of you." As I knew that many of the students had been Confederate soldiers I embraced the opportunity for a little bit, "O, no!" said I. "Wear them as an emblem of the Union." "I don't know as we shall prize them much as an emblem of the Union," 
was the reply "But we will wear them in remembrance of you and your school," and bowing politely they passed out. We learned afterwards that they spoke in the highest terms of the school, and the proficiency of the colored pupils in their studies, and we were also told that these two students were at the head of the classes.

We were the recipients of frequent notes from students expressing an interest in our work and asking permission to call on us. We invariably replied that we should be pleased to receive them as visitors in our school any day they chose to call. On a few occasions some of them called at our rooms without the formality of a note asking permission-by merely sending up a card at the door. At such times Miss Gardner always insisted, spite of my protests, that we should receive them. However I took care to throw the burden of the conversation upon her, which I think was much to her liking, as I knew she enjoyed subjecting them to a moral and intellectual dissection.

More than once while we were in $\mathrm{C}$. there were quarrels among the students which ended fatally. Knives and pistols would be drawn upon the slightest provocation, but if a student were arrested and put into the jail his fellow-students would batter down the doors and release him. In what was called the "University Burying Ground" we were shown the graves of two professors who were murdered by students.

The rougher element among them showed a special spite towards any colored man or boy who was neatly dressed, usually knocking him from the sidewalk if nothing worse. Occasionally some high spirited young colored man 
would resist such interference when, perhaps pistols would be drawn on both sides. Luckily in every instance that came to my knowledge there were cooler heads who used their influence with both parties and prevented bloodshed - and possibly a race war. As for the young women and girls, many of whom were nearly as quite white, and some of them remarkably pretty - they were in constant danger of insult and abusive treatment, and the young colored men were frequently warned of punishment that would be meted out to them if they were rash enough to act as protectors of these girls by escorting them when it was necessary for them to go out in the evening. If a young girl left unprotected in the evening reached her destination unarmed, she could well consider herself as cared for by a special Providence.

In these days when I hear so much of the crimes committed by colored men upon white women, I hearken back to that time when I knew that any colored woman was looked upon by (shall I say) a majority of the white men of the community as their rightful prey, and she was in a sense helpless and unprotected by the law as well as by public opinion. It seems a terrible accusation to make, but nevertheless I believe, that at the time I was there, there was nothing else in the locality that had so demoralizing an effect upon the colored youth of both sexes as our vicinity to the University of Virginia. Many of the growing boys were employed by students as servants where they were pretty sure to receive an education of a most undesirable and vicious nature. And the girls - just released from slavery where their status was about the same as that of the domestic animals - is it any wonder that many of them were morally weak 
while all were practically defenceless? And it was a common and bitter experience with us to have some girl of whom we had hoped to make a bright particular star for the guidance and uplifting of the race, disappoint our hopes in the cruelest way through the temptations and influences emanating from the University.

I have not written thus strongly in condemnation of the University and its students, because of the occasional annoyances we suffered through their actions. On the contrary I have vainly endeavored to recall something of which I can speak more favorably, but my utmost efforts to do so have failed. I am sorry, for I would like to say something pleasant of this great work of Jefferson - this largest of Southern universities. I have "set down naught in malice" and heartily which it might have been my good fortune to have caught an occasional glimpse of the "silver lining" behind the clouds I have described. I firmly believe the "silver lining" was there, but from our position only the dark side was apparent. It would give me great pleasure to learn that the unfortunate conditions I have described no longer exist and that this great college has attained to the ideal of its founder.

\section{Chapter Sixth}

Our Homes and School Houses.

Our first home was in the large brick building described in a previous chapter and known as the Mudwall, or Delavan. It was three stories high and there were eight rooms on the $2 \mathrm{~d}$ floor and the same number on the $3 \mathrm{~d}$. The lower floor was 
described in Chap. 2d. There was also a basement with several cellar-like rooms where some of the very poorest colored people were allowed to burrow while the property was held by the U.S. government. The rooms above were all exactly alike. A door opened from the hall, opposite which was one large window. A fireplace was built across the corner of the room, over which was a mantel. There were no closets or anything to take away the bare appearance of the plastered walls My room was furnished at first as described in Chapter $2 \mathrm{~d}$ but I gradually accumulated a few necessary articles: a desk, an extra chair or two etc. It did not required much to make me comfortable then, and bare walls, and bare floors were circumstances hardly worth considering as I mentally contrasted the luxury of our surroundings with the homeless life of the poor soldiers whose toil and sufferings, had made this opportunity possible. This was our home for the first year and a portion of the second. Our schoolrooms were in the long building mentioned in a previous chapter. My own was at the front end to the left of the hall. Mrs. Gibbons', one of the colored teachers was opposite mine at the right. Miss Gardner's at the extreme rear at the left and Mr. Pratts (previously taught by Mr. Musgrove a citizen of the place, and after Mr. Pratt left by Paul Lewis one of Miss Gardners' pupils was opposite hers. Between my room and Miss Gardners were two large rooms, which served as a place for the pupils wraps, and storage for fuel and other purposes. The large space between the two schoolrooms on the right was used for a time by the colored people for a Baptist church. While Mr. Woodman taught there his school was up stairs on the right side at the front. Paul Lewis, with his family had living rooms up there, and 
also his father and mother, who had with them a daughter son and grandson.

Behind the rooms I have mentioned there was a large amount of unoccupied space until the Delavan, where we lived was ceded back to the original owners, by the United States government, when Miss Gardner and I had each two rooms fitted up there for our use which we occupied April 5th 1867.

These rooms were quite large. My sitting room had two windows at the north and two looking east - my bedroom one window only facing east. This rear room was my dining room and storage place as well as chamber. The two occupied the space immediately above my schoolroom. The inner walls of the whole building were clap-boarded like the outside of a house. These walls were freshly whitewashed every year as long as we lived there and the school-rooms were decorated with wreaths and arches of evergreen which the boys would go out and gather at stated times when all hands would go to work to decorate. One huge wreath made on a barrel hoop was hung from the ceiling in the centre of the room. Arches were placed above each door and window, and large wreaths hung in the spaces between. The effect was very pretty and cheerful, taking away the grim unfinished look of the rough walls. We were too much interested in our work and too busy to let our imagination dwell upon the dark stains here and there upon the floors, stains as unremovable as those upon the keys of Bluebeard - and as significant,- -but the superstition of some of our colored friends peopled the building with phantom soldiers who flitted restlessly about the place at night. Poor fellows! If they did gather about the last scenes of their life 
on earth, they kindly refrained from disturbing us, and we lived there as serenely as if there were no phantoms of friends or enemies about us.

For some years our school furniture consisted of rough benches without backs, and a few rough tables doing duty as desks. Indeed we had little else until we built a school house some years later. The furnishings of my sittingroom consisted of an air tight stove, a long narrow rough table which I covered with a green cloth, and upon which I kept books, ornaments, etc. a small table, four or five chairs and a wood box. Anything served as an ornament for the walls - wreaths, pictures cut from magazines, and papers etc. This was our home and work shop for some three years or a little more, and I will try to give here a rough outline of the building as I recall it now after the lapse of more than thirty five years. $^{282}$

The points of the compass on these rough plans (drawn mostly in pencil for convenience) are those used on maps, so one can see that the house fronted north or nearly so. The Orange \& Alexandria R.R. passed directly in front of the building not more than a rod from the door, and there was a large open lot between the railroad and the street, which our pupils used as a playground.

On the east of the school-house was a small brick yard, and there was quite an extent of open ground at the west and south. At the end of the time mentioned above the U.S. government gave the building for a school, and with help from the Freedmens Bureau and the aid gained through friends at the North and some work on our own part in getting up entertainments of various kinds we

\footnotetext{
282 In the original document two diagrams followed which show the layout of the building.
} 
got the means to buy the land and take down and rebuild the house in a manner better suited to the purposes of a school. This was mostly done during the summer vacation of three months although we found quite a little to be completed when we returned to our work in October.

The new house had two schoolrooms on the first and two on the second floors. In the rear of the lower schoolrooms were two living rooms for the janitors family - Paul Lewis one of the teachers acting in that capacity at first. Miss Gardner and I each had a sitting room above the janitors rooms and we also each had a rough room fitted up as a sleeping room in the loft. By this time we had begun to come to an appetite for a few simple luxuries, so I got wall paper and put it on myself and we each indulged in a modest carpet. Miss Gardner bought a second hand lounge, and I got together some pieces of timber and boards, and with the aid of one of the boys built one for myself stuffing and covering it nicely, so at last we began to live in a civilized way. Aside from one or two slight changes we had made in the building everything seemed settled for the rest of the time we remained there. The changes consisted in enlarging one of the lower rooms by taking in the hall which gave space for a small stage, or platform where we could have entertainments or other gatherings. A piazza was also built each side of the projecting porch, and doors were cut from our living rooms up stairs into our school-rooms. The schools were all furnished with plain durable desks black boards and maps, and a few pictures. A small library was collected for the use of the schools, and later a Worcesters, Unabridged Dictionary and a magnetic globe were sent us as well as a few other necessary small articles. We used as text 
books Hilliards Readers, Keels Grammar, Greenleafs and Robinson Arithmetics Colton \& Fitcher Geography, various books on U.S. History, Geology, Algebra Philosophy, Botany, Literature, etc. In short we were not confined to special text books, but read and taught from what seemed to offer the best instruction. We naturally became much attached to the homes and schools that had grown up under our hands, and gained in usefulness and comfort with the years, and although some of the details of that old time picture cannot now be accurately recalled, the general idea of the whole seems to stand out as clearly as ever. In a sense our home there was more to us than it might have been under other circumstances for we had little or nothing outside our homes and our work, except as it reached out and included the social religious and political life of the people: and although their lines of work reached far out into the country about us, they all centred in the spot where we lived and worked. ${ }^{283}$

This is a very rude and imperfect outline of the lunchrooms of the new home. I never read the measurements and I can see that I have failed to get the right proportions but it will give some idea of the form and arrangement of the rooms. The upper hall should have been made wider with little ante room at the entrance to the schoolrooms. There was a stairway leading to the attic near the entrance of the rear hall under the whole schoolhouse was a basement woodroom.

\section{Chapter Seventh.}

The Military

\footnotetext{
${ }^{283}$ In the original document a diagram followed which show the layout of the lunchroom area.
} 
When I reached Charlottesville March 2d-66 I found a small guard of soldiers stationed there under command of Major Head. I think these troops belonged to some Pennsylvania regiment but do not remember which one. The Majors Headquarters were in the Delevan where we had our first home, and the soldiers barracks were at first in the long building where we had our schools, but they were soon removed to the good-sized structure connected to the rear of the Delevan by a square platform: so we who were occupants of the house lived a kind of semi-military life. As our work took us to our schoolrooms frequently in the evening we became quite accustomed to the challenge of the sentinel on our return "Who goes there?" "Friends." "Advance friends and be recognized." After which ceremony we could pass into the building and up to our rooms. The presence of Mrs. Head, whose mother and sister, visited her separately during the spring; gave us a little pleasant Society. Major Head was a good disciplinarian and as a rule the soldiers were orderly, but occasionally some one would be guilty of some misconduct - usually it would be a case of too much strong drink - and be put under guard. Such cases usually came under our notice as the guard would have to bring his prisoner to the common pump to wash his face and hands. One morning when I rang my bell, a very young soldier under guard at the pump, evidently under the impression that he was a school boy, walked quietly in and took his seat with the boys in spite of the protestation of his guard who was too much taken by surprise at his unexpected movement to stop him before he got in and seated himself. It was quite evident that he was under a drunken delusion, and it took considerable energetic waxing 
on the part of his guard to get him away. Judging from his looks he had not been long out of school.

Occasionally some of the soldiers would indulge in a little sport at the expense of the colored boys and frighten them by chasing them around the building when they were sure the Yankee teaches were not where they could see them. But we always knew about it for some of the boys who were sure to complain to us that the "Yankees have been running us." All soldiers who wore a blue uniform were "Yankees" to them, whether they came from Maine or Oregon. We rarely heard them spoken of as soldiers. In fact I think the white people always gave them this title - to them a most offensive term.

But whatever may have been the faults of the soldiers, we were treated with the utmost courtesy by them. Wherever we met them they silently raised their caps, or put up a hand in military salute. There were only two or three whose names we learned out of the crowd of seventy or eighty stationed there. The Majors orderly and one or two others but they all knew us and gave us the same courteous recognition as they tendered Mrs. Head, the Major's wife.

Our pupils used to bring us the greatest profusion of the most beautiful flowers - so many that they actually constituted "an embarrassment of riches." I had so many one day that I left them in the school-room until one of my girls could get a basket to bring them over to me. When she came she said the soldiers at the barracks in the rear of the house tried to coax her to let them have some. "Please give me just one white flower." But she sternly refused. "They are all for Miss C" she told them. I told her I thought I might share a few out of 
half a bushel, so I filled two or three vases and sent the rest down to them. If there was a sick soldier in the hospital we shared our flowers with him, and we often furnished the soldiers with enough to decorate the graves of the Union dead who rested in the University burying ground a half mile away. After the soldiers were gone we used to make little pilgrimmages to the place with our own offering of flowers until the bodies were removed to the national cemetery at Culpepper.

In the latter part of May of '66 we were told that orders had come for the troops to be removed from Charlottesville. The colored people were very much alarmed, and we felt that our position there would scarcely be secure without their protection, so with the approval of Maj. Head, and the other teacher Miss Gardner went to Washington to appeal to the authorities there to allow the soldiers to remain a while longer. They gave her request respectful consideration, but their final conclusion was that a guard was no longer necessary there, and on the morning of the 8 of June, a special train stood on the track about two rods in the rear of our home and we sat at the windows and watched the soldiers file on board. When all was ready for a start Miss G. said "We ought not let them go without a sign that we notice their departure" so we waved our handkerchiefs as the train moved off. Instantly the soldiers swung their caps in return, and gave us three cheers. So ended my small experience of military life. We heard of many threats to break up our school after the soldiers left. I find in my diary of that date this significant item. "they threaten to drive us 
out", but we went on with our work as if we had no thought of trouble, and it proved the wisest course, for the trouble did not come.

\section{Chapter Eighth}

Our teachers.

When Miss Anna Gardner was sent to Charlottesville in the autumn of '65 she found a school for colored children which had been opened by a Mr. Musgrove, a white citizen of the place. She reported the fact to the Society in Boston at once, and they as promptly offered to adopt his school and pay him a salary for his work. He was glad to accept their offer, as he had been teaching for such uncertain and meagre fees as the poor colored people could pay, and the change to sure and definite wages was naturally agreeable. He held the position of teacher for the Society but a short time, however. His methods of teaching the various branches required were not up to the standard, and the Committee felt that they could not afford to waste the funds of the Society; so, he was removed to make way for one considered more satisfactory. We all regretted that the Committee was not willing to have given him a longer trial as he had enlisted so promptly in the cause of teaching the freedmen. It seemed to us that a few timely hints as to methods, and a little time given for opportunity to improve would have been both just and wise, and we made an appeal in his favor, but they seemed to feel that the welfare of the school depended upon the change, 
and so the change was made and Mr. Musgrove no longer formed one of our corps of the teachers.

Miss Anna Gardner, the first teacher sent to Charlottesville by the Freedmens Aid Society organized the school in the autumn of '65. She was a native of Nantucket, and was a woman of middle age when I made her acquaintance. She was an old time abolitionist, and had stood before furious pro-slavery mobs with Garrison, Phillips, Steven \& Abby Kelley Foster, Lydia Maria Child, and others of the famous anti-slavery people who fought the "sum of all villianus" in those never-to-be-forgotten years that preceded the Civil War. She was a Quaker by birth and education but she was a soldier by nature although her Quaker training made her deprecate bloodshed. But she was always ready to meet the foe in argument, and never handed down her flag or sounded a retreat. She used to say that she was a physical coward, but she rightfully claimed that she was morally brave. For the first two or three years of our work there she seemed to be in constant dread of danger from mobs, or secret assassins, but in spite of her fears she never hesitated to say or do the thing she thought ought to be said or done, regardless of the irritation or anger it might cause among those who were opposed to both our work and our presence among them. I think now it would have been wiser had she taken a more conciliatory tone in her dealings with a people who were sore from their recent struggle and defeat. But she was aggressive in the honesty of her opinions, and seemingly could not make allowance for the different views held by her opponents. 
She was a most excellent teacher, never permitting a half understanding of any subject in her pupils. Every step must be made perfectly clear before the next was taken. When the school was fairly organized and graded she was placed at the head as Principal, a position she held for more than five years. The school at Charlottesville was not her first experience among the Freedmen. She had previously taught in New Bern N. C. and after leaving Charlottesville she taught some time in Elizabeth N. C. Her interest in the colored people had formed a part of her whole life. In 1838 when a very young woman, she opened a school for the colored children of Nantucket, who were not then allowed public school privileges. She had a beautiful, heart-shaped gold medal which those pupils presented her, which was engraved with a statement of this fact. She had aided many poor fugitive slaves to escape, by secreting them and in other ways assisting them to gain their freedom across the line in Canada. She told me that one of her first recollections was a fugitive slave whom the man hunter had traced to her fathers house. She could never forget the contrast between his black skin and the ashy whiteness of his lips when he found they had come for him. Her father managed to get him out of an obscure rear window while the search was on, and other abolitionists aided his escape. She came of good old anti-slavery stock One of her ancestors was the "Goodman Macy" of Whittiers poem. ${ }^{284}$ Mrs. Phebe Ann Hanaford was her cousin, and she numbered among her friends most of the noted people of the day. She wrote articles for various periodicals upon the burning questions of the times - Temperance, Anti-

\footnotetext{
${ }^{284}$ See Whittier's poem.
} 
slavery-Woman Suffrage etc. Some of these with various poems, and other articles from her pen were gathered into a small volume called "Harvest Gleanings," not many years before she died. This work was done under the supervision of Mrs. Hanaford. ${ }^{285}$

When well along in years Miss Gardner met with a serious accident which crippled her for life. She attempted to rescue a child which had been thrown down in the street under the feet of a horse and her hip was broken in doing so. Miss Gardner lived beyond the four score mark and was bright and active to the end. We corresponded regularly for a number of years until her eyesight failed her, and after that occasional letters passed between us. ${ }^{286}$ She was one upon whose friendship I felt I could always rely. One who was never afraid to criticize my work or disagree with me when she thought me in the wrong, and for that reason I came to feel that I could always learn the truth from her - the truth as she saw it, and I knew that a word of praise from her lips was of value, for she never bestowed it to flatter ones vanity or win his good will. A good, brave, noble woman, who always did the thing that seemed right in her eyes.

Another teacher from the north had preceded me by a few months - a young man from Newburyport Mass., Mr. Charles $\mathrm{H}$. Woodsman. It was a strange thing for the Society to do, particular as they usually were not careful to send very young or inexperienced teachers into the field, that they should have made an exception of this wholly inexperienced and immature boy of eighteen years. Two circumstances evidently influenced them in his favor. He was enthusiastic in the ${ }^{285}$ Harvest Gleanings
see Boston Public Library Letters. 
cause, and had the warm friendship and admiration of an influential member of the Teachers Committee. He was a bright, intelligent well-meaning lad having a fair education, and doubtless entered into the work of teaching the Freedmen with the true missionary spirit, ready and willing to make sacrifices if need be in the cause. But he knew nothing of teaching and the position in which he found himself held many temptations for an immature young man, whose moral stamina had not become sufficiently strengthened by the habits of self-control.

He remained until the close of the school year at the end of June, but was not given a position again in Charlottesville or elsewhere.

When I had been in Charlottesville about two months a change was made in one of the schools - Mr. Musgrove being removed and his school put in charge of Mr. John Wesley Pratt of Massachusetts who took charge of the school the latter part of April. As I remember Mr. Pratt I should say that he was upwards of forty years old at that time. He was a successful teacher but only remained in $\mathrm{C}$. until the end of the school year, as the Committee thought it best to put some of the more advanced of the colored pupils in charge of the Primary classes, so Mr. Pratt, with his wife and young son were sent to Orange Court House, Va where they taught for some time - I do not now remember how long, but probably as long as the Society continued to support a school in that place.

The next teacher to assume her duties under the auspices of the Society was a native colored woman, Mrs. Isabella Gibbons. I think she opened her school in the fall of 1866. Her husband was a Baptist preacher of a great deal of untutored power and eloquence. They had both been slaves and were especially happy to 
be free, as they had a large family of children for whose welfare they were naturally anxious. Mrs. Gibbons was a handsome, capable woman, some thirtyfive years old. She made an excellent teacher. She was one of the colored people who had rendered much aid to sick and wounded senior prisoners lodged in the hospitals around Charlottesville. She continued in the work during my stay there, and for several years after I came away, being employed by the local school board.

In February 1867 a colored man Paul Lewis, who like Mrs. Gibbons, was one of Miss Gardners pupils was placed in charge of another school of the same grade as that of Mrs. Gibbons. Both of these teachers were given positions with the understanding that they should continue their studies while teaching. Paul Lewis was a slave of Hon. Alexander Rives. His mother was the nurse of Mr. Rives children. He was wholly unlike Mrs. Gibbons who was very quick and bright. Paul was slow, but deep. He made a good teacher, adopting Miss Gardners methods of instruction, and drilling his pupils very thoroughly. $\mathrm{He}$ continued in the work for a year or two after I left, and then owing to some trouble he had with a white resident, he lost his position as teacher, and resumed his old trade of shoe making.

In 1871 Miss Gardner thinking it best to make a change, resigned her position as Principal of the school at Charlottesville and I was promoted to fill her place. Miss Annie D. Holmes of Chelsea Mass. was elected to the position made vacant by my promotion. Miss Holmes had already had a large experience as teacher among the Freedmen. She had taught on the South Carolina islands, and in 
Columbus and Jonesboro Ga. and Gordonsville Va. and brought to the work in Charlottesville all the advantages gained from that experience as well as her natural intelligence and enthusiasm for the work. She possessed the gift of winning the confidence and affection of her pupils in a marked degree. She was very independent in her views and actions, and set about rectifying what seemed wrong in her eyes with absolute fearlessness as regarded consequences.

Our stations were of the pleasantest nature and I felt the deepest regret when, at the end of two years, the Society in Boston decided to withdraw her from Charlottesville and put her to work elsewhere. This was in accordance with the rule they had made of gradually dropping their work into the hands of the local school-boards. Miss Holmes went again to Georgia, and I was left the only white teacher in the school where I remained two years longer. But our friendship has survived more than thirty years of separation fed by the remembrance of our work together, and by occasional meetings and an irregular correspondence.

The isolated northern teachers felt for each other something of the comradeship that soldiers feel for their companions in march and battle. We were, in a sense in the enemys country, and looked to each other for companionship and support amid trials which it would be difficult for the uninitiated to understand, because only those who have lived the life can know the brightness of it's sunshine or the darkness of its clouds. But however black the clouds might sometimes hover, I do not believe there is a surviving teacher of that period who would say that she was sorry she had been given the opportunity 
to taste the bitter as well as the sweet of the life of a teacher among the

Freedmen. $^{287}$

\section{Chapter Ninth}

Our Schools

When I went to Charlottesville in the spring of 1866, the various schools that had been opened for the benefit of the Freedmen were wholly independant of each other. Each teacher admitted as many pupils as he or she could accommodate without regard to educational qualifications: for in spite of the fact that it was unlawful in Virginia to teach a slave to read, many of them had tasted the forbidden fruit in one way or another, so there was quite a material difference in the attainments of the applicants for admission to the "free schools" as ours were called by the colored people.

Miss Gardner had been quick to recognize the necessity of better organization and placed the matter before the committee The result was that I was sent to take charge of the pupils collected under her care, with the exception of thirty of the more advanced who remained with her, forming the nucleus of what was later styled the High \& Normal department of the school. In addition to the thirty or forty pupils that came under my care from Miss Gardners room I admitted a sufficient number of outsiders to increase my number to seventy or more. A year or so later the schools were systematically graded - two rooms being devoted to

${ }^{287}$ Note text in another hand. 
the Primary department, from which the pupils graduated into the Grammar School and from there to the High School.

It must be explained here that the status of this school was not the same as that of a High School in one of our northern cities or towns. As a High School it was simply a dream of the future, but the object was to make it a reality as speedily as possible.

The branches taught in this grade were Reading, Writing, Arithmetic, Grammar with composition, Geography, Natural Philosophy, History, a little geology etc. etc. It was necessary that the languages, higher mathematics etc should wait until the pupils strongly understood those branches which would be of most importance in their every day lives. So the branches taught in the two upper grades differed less in kind than in degree. The pupils in the Primary department learned to read write and spell and were grounded in the rudiments of Geography and Arithmetic. The two teachers in this department - Mrs. Gibbons and Mr. Lewis followed the methods of Miss Gardner by whom they had been themselves instructed so their classes always entered the Grammar School well fitted to take up the work which was expected them there.

As years passed, the grades advanced somewhat, but owing to the difficulties of the situation, the schools could not in the few years we spent there be raised to the level of the same grade in the North, but the few branches studied were thoroughly understood not only as regarded the facts themselves but the causes underlying those facts. We found the colored people were naturally dramatic and many of them had beautifully soft and clear voices so they were easily taught to 
be fine readers and speakers. Aside from this they were, like pupils everywhere, some proficient in one branch, some in another, and some seemingly mere dullard, although we avoided as far as possible admitting pupils of the latter class, as it would have been a waste of our time and the means of the Society to give instruction to such when those of better ability were waiting to be taught. We were supposed to give our time to such as would be useful in the uplifting of the race. The dull ones were not to be neglected in the end, but our first object was to push the bright adult pupils forward as rapidly as possible that they might serve as teacher for others, younger or less brilliant.

In the early years of our work there it was suggested that each teacher give a name to his or her school. Miss Gardner was a great admirer of Thomas Jefferson so her school was named for him. In tender remembrance of our recently martyred President, mine was called the "Lincoln School" The Primary school under Mrs. Gibbons was called the "Major Savage School["] in honor of a Union officer who died a prisoner in Charlottesville and whose remains were interred in the cemetary just beyond the buildings of the University of Virginia. The Primary school taught by Paul Lewis was called the John Brown School after the hero of Harpers Ferry. When the new school home was built it was named "The Jefferson School" as it had now become one school of three grades with a Principal and sub-teachers. Our school hours were from 9 A.M. until 12 and from 1 to 4 P.M. every week day except Saturday Our holidays were Thanksgiving Day, Christmas wee, the Monday after Easter, and the Monday after Whitsuntide. The Christmas holidays included New Years, \& Emancipation Day. 
Many of our pupils came long distances - from two or three to five or six miles to school I remember one boy of 18 or 19 years who lived five miles away, and attended school regularly although he had to earn his living by working at his trade - shoe-making-in the evening He told me after he left school that he hardly knew how he lived at the time. There were many others who made a similar struggle in order to enjoy the privilege of attending school. To them the old adage "Knowledge is Power" was full of meaning, and they felt its truth in all its intensity. ${ }^{288}$ They felt that the power of their white superiors lay in the education that had been denied them so they thought that no labor was to arduous, and no sacrifice too great, so that they might drink of the cup held out to them by their friends at the North.

The colored people are naturally very musical and our school exercises were usually opened and closed with singing. The songs were various in their nature. Sunday school hymns, Temperance songs, and songs born of the events of the Civil War were the most common. Mrs. Howe's "Battle Hymn of the Republic" was a favorite. For special occasions we wrote the words of songs which were adopted to well known tunes. It was a pleasure to do this, they all seemed so pleased with a song prepared expressly for them.

Miss Gardner and I each fitted words to the once familiar tune "Kingdom Come,"289 and many other popular tunes were made to bear similar burdens. I don't know how it happened that the old plantation hymns were never sung in our schools. Perhaps they carried with them too strong a savor of the old slave days.

\footnotetext{
${ }^{288}$ Locate author.

${ }^{289}$ Locate author.
} 
However that might be, some of our pupils in after years travelled the world over singing these old slave melodies before vast crowds of enthusiastic listeners.

It would be hard for one educated in our public schools, to understand the confused idea many of the freed people entertained concerning the relation of cities and towns to the States - in regard to historical facts and many other circumstances. I happened to mention one day that I came from Massachusetts. "Is Massachusetts in Boston?" queried one of my pupils. In the minds of some of these people, Boston meant the whole North. All their hopes seemed centered in this great, all-embracing Boston. I will relate another little circumstance which will give an idea of their hazy views in regard to historical facts. One day in our reading we came upon something relating to Bunker Hill so I told them about the great battle that was fought there in 1775. "Were you there?" ["]Do you remember about it?" were the questions asked. To their minds all wars were included in the Civil War which meant so much to them. At another time I was explaining the lines on the map of the earths surface to a class in Geography. I was careful to speak of them as imaginary lines, but the adjective evidently did not impress itself upon their minds as it should have done for at the end of the lesson one boy remarked that he should think that "ships at sea would get all tangled up in the equator." These incidents will serve to show that we had to begin at the very bottom of every subject taught. Even the common, ordinary words we used in explanation of facts, often conveyed a different meaning to their minds from that intended. The first day I taught in school I dismissed them for the noonday recess at twelve o-clock. "Shall you have school this evening?" 
they asked. "No" said I "There will be no school in the evening." At one o-clock I rang the bell, and about a dozen or fifteen pupils straggled in. "Where are all the others?" said I. "They said you wouldn't have school this evening" was the reply.

So I learned the meaning of the word "evening" as they understood it. One day when two or three women - parents of some of the pupils were calling on us, the conversation turned upon a boy who had many very peculiar traits, and I happened to remark, that he was a "great rogue" They seemed much shocked, and one of them said that she "never thought that of him." I assured her that "I didn't mind it at all." In fact "I rather liked a rogue." This was more shocking still until Miss Gardner, who was quietly laughing to herself, said "They think you mean a thief," and explained to them the different meaning we gave the word in the North. So my reputation was saved from the stigma of encouraging a thief.

The work of taking care of the schoolrooms was performed by the pupils under the supervision of the teachers. The girls did the daily sweeping and dusting, and the boys cut the wood, and made the fires. When there was a regular cleaning up the boys and girls were both pressed into service.

Occasionally some of the older boys would do a little job of carpenter work, or other repairing, like setting panes of glass, or fixing a refractory lock, re hanging a door etc.

The text books used in the schools were shipped to us from the rooms of the Society in Boston and sold to the pupils as needed, the money thus received being credited to the Society as such a part of our wages. After the Society co- 
operated with the local school board the text books of the state of Virginia were introduced into those department that fell under their supervision.

Very soon after I began teaching in 1866 I opened an evening school for adults, holding a two hour session three evenings in a week. I kept this up for about two years, until we had trained some of the more advanced pupils to take up work of this kind. In this class I had pupils from twenty, to more than sixty years of age. The very oldest attempted nothing beyond reading and writing, but many of those of forty years and under made remarkable progress. One woman who did laundry work told me she kept her books on her ironing table and learned her lessons while she worked and nearly all these adult pupils found it necessary to pursue their studies under similar difficulties. But they were in earnest and determined to overcome all obstacles. I remember when I reached home one summer, I found a letter awaiting me which had anticipated my arrival by a day. This letter was from one of my evening pupils - a woman named Johnson, who, six weeks before could not form a single letter with her pen. It was a wonderful satisfaction to her to be able to send me the first letter I received from the South during my summer vacation.

It will be readily understood that there wasn't time in the few brief hours I could devote to the evening class, to give instructions in many branches. I taught them to read, spell, and write, and they learned the rudiments of Arithmetic.

Some of the brightest pupils became quite proficient in the latter branch-through decimal fractions. 
This seems a very meagre education: but it meant much to them, and they showed that they appreciated my efforts to help them in every way they could. Their efforts to show their devotion to us were often pathetic in their eagerness. They blossomed out in the form of gifts of articles which they thought would please us, and which we often felt they could ill afford. We were the recipients of numerous pieces of gaily decorated china ware - cups and saucers, plates, vases, mugs etc. and sometimes articles in silver were given us. Now and then some one would select a book or picture as an offering. Flowers and fruits were showered upon us in their season and the amount of cooked food that was brought us at certain times would have enabled us to set up a boarding house. I had a rough table which must have been at least seven feet by three, and I now recall one Christmas when it was loaded with food from end to end. Chickens fried and roasted boiled ham, roast pig (or shote as they called it) baked fish, oysters, salads, sweet and white potatoes, squashes, parsnips, turnips, onions, cabbage, apples oranges bananas, grapes raisins figs dates nuts pies, cake, blanc, custards, bread, rolls, crisp little short biscuits, and the delicious Virginia Sally Lunns, with plenty of candy to sweeten us up. Nor did they show their devotion to us in gifts alone. They got up feast, and picnics, and barbecues, and every kind of entertainment in their power for our amusement, and frequently some of the young men who owned musical instruments would bring their violins or guitars and give us an evening serenade. Each summer when we left for our annual vacation early in July they bade us God speed with sad faces and many tears, and they welcomed our advent in late September with many 
demonstrations of joy It may be true that as a race these people are apt to be careless and thoughtless, but I can testify that they were ever thoughtful for us, and spared no pains to make our life among them as pleasant as it lay in their power to do.

As every circumstance of our lives in Charlottesville was in some way connected with our school work it is not necessary to give further special attention to this subject.

\section{Chapter Tenth. \\ Entertainments}

As the colored people were not permitted to share in the amusements of the whites except in a manner to emphasize the fact of their degradation we felt it incumbent upon us to have some sort of entertainment of a moral and educational character, which should serve both to instruct and amuse; and the most available plan at first was the School Exhibition in which songs, recitations and dialogues formed the whole of the program. These were all carefully selected by ourselves, and each pupil given the part but adapted to his ability. Miss Gardner, as Principal was the first to bring out her pupils in this way, and the other schools followed in succession, so that the School Exhibition came to be looked forward to by the pupils as an agreeable change from the ordinary routine of school work. Miss Gardner also originated the idea of a Masquerade party, and we selected all the characters and planned the costumes for the maskers. In all these entertainments we were greatly assisted by two of the most 
prominent colored men in the town - Messrs Robert and James Scott, brothers, who with the son of the former, Robert Scott Jr. furnished us with the best music the town afforded. The Scotts were noted musicians, and their services were in demand in the most aristocratic families of Charlottesville.

After I became Principal of the school, I formed among my pupils the "Jefferson Amateur Diamond Association." Our plays dealt largely with the question of intemperance, as the drinking habit was so common among both the white and colored people of the place. If my memory serves me rightly "Ten Nights in a Bar-room ["] was the most pretentious piece we put upon the boards. ${ }^{290}$ "Bakers Temperance Dramas" furnished us several "The Little Brown Jug" "The Last Loaf" "Man with a Demijohn," "Seeing the Elephant," "We're all Tee totallers" etc. I also remember one called "Aunt Dinahs Pledge" which I picked up somewhere and I also found plays on other subjects suited to our needs. We usually charged an admission fee of $15 \mathrm{cts}$. and we always had a few white people in the audience. It would give a real actor spasms to look over our stage properties. For instance, in the scene in the wood, or grove in "Ten Nights in a Bar-room" small evergreen trees were made to stand on the stage through which the actors skulked in and out as necessary. For the Bar Room a long wooden table was arranged with glasses, bottles, etc. to resemble a bar. In "Seeing the Elephant," the huge beast was made of two boys, two paper cones,

\footnotetext{
${ }^{290}$ In the 1840 s Neal Dow of Portland, Maine, became actively involved in prohibiting the manufacture and sale of intoxicating liquors. He achieved his goal in 1851 when the "Maine Law" was enacted. Thirteen of the thirty-one states had a similar law by 1855 . In the 1870 s groups of women added their strength to the temperance movement. Frances Willard became president of the Woman's Christian Temperance Union (WCTU). These groups of women were active in every major city in the North. Freedmen teachers actively carried the temperance message to the South by incorporating the tenets of the movement in their teaching methods.
} 
and a grey blanket. Where money was required Confederate bills of which plenty could be obtained at that time, were used.

We also had entertainments, consisting of tableaux charades etc, and we occasionally consented to the pupils holding a Fair for some special school purpose All the money raised through the different entertainments was used for some special school purpose. We also formed Societies for various purposes. A Freedmen's Aid Society" as a branch to the one in Boston, A Mutual Improvement Society," A "Union League," The "Cheney Society" The "Equal Rights Association" The "Gardner Society" etc. These did not all exist at the same time, but were formed when occasion for some new organization seemed apparent and disbanded when the object was obtained or seemed no longer desirable. Sometimes one organization became merged in another of a different name but similar nature.

The colored people often prepared entertainments for our especial benefit. Sometimes it was a picnic or a barbecue - sometimes a feast at one of their houses. When it became a matter of preparing good things to eat, there was never any lack either in quantity or quality. It was a matter of regret to us that these poor people should so strain the small means at their disposal, to make a feast for us, but, the cost incurred, there was nothing for us to do but to show our appreciation of their efforts by enjoying the same.

I have mentioned in a previous chapter that we were frequently treated to a serenade in the evening 
At Christmas we usually had a tree with gifts for all our pupils. These gifts were sent to each school by the special branch society actively interested in its welfare, and consisted of books, pictures, clothing, handkerchiefs and other articles of use or for omament. I will describe one Christmas festival which was a little out of the ordinary. That year our branch society failed to send articles suitable for a tree in sufficient number to supply more than twenty or thirty of my seventy odd pupils. I explained the matter to them and asked if they were willing that the contents of the box should be distributed among the very poor, to which they readily consented. I then arranged a program for a little festival on Christmas eve in which the exercises were to be in singing, reading, etc. A few days later Miss Gardners society sent her an enormous box, with special gifts marked for each of her pupils, besides a vast number of other nice things; and she generously offered me enough to put with the few suitable articles I already had to make a nice gift for each member of my school.

As they expected nothing I planned a little surprise for them, and arranged with one of Miss Gardners older boys to act the part of Santa Claus It being difficult to procure a sledge, with the proper supply of reindeer, I had a barrel filled with the gifts neatly done up and marked. This was placed on a wheelbarrow, in the room back of the school room, while we went through the exercises of the evening as planned. When we were all through with the exception of the closing song, I made a little speech in which I told them that without doubt, anta Claus appreciated this unselfishness in donating their Christmas gifts to those more needy than themselves, and as he was probably 
riding about that evening, $f$ we could hail him in passing he might possibly be induced to make us a call. Two of the older irls were appointed to look for him. By this time the interest and curiosity of the pupils was at its height, and they watched with eager eyes as one of the girls opened the stove door, and called "Santa Claus! Santa Claus!" There was no response and I told them the stove pipe was probably too small for him to come through with his pack so they had better try the door. They opened the door into the hall and repeated the call but in vain. Then they went to the back door and called. Immediately a figure with a long white beard, and clad in furs, pushing a wheel-barrow in front of him passed through the aisle and stationed itself in the open space before the platform.

What a moment of excitement followed! They jumped up and down and clapped their hands, and cheered and shouted until it was a perfect pandemonium and it took some time for them to subdue their emotions sufficiently to enable us to proceed with the distribution of the gifts. The surprise was perfect, and the value of the simple gifts correspondingly heightened.

As a rule our Christmas entertainments consisted of recitations, singing, and a tree and we usually had some kind of a celebration on Jan. 1, Emancipation Day and on several occasions we combined the two, postponing our Christmas festival a week. Christmas had always been the greatest day of the year with the colored people, whether bond or free, but we did what we could to teach them, the importance to themselves, of Emancipation Day.

On April 19, 1875 we celebrated the day by reading the story of the "Concord Fight" and many other entertaining bits of history of Revolutionary days, and the 
singing of patriotic songs, with speeches by their friends who came to witness the exercises etc so while Massachusetts town was rejoicing with elaborate festivities we had our humble celebration six hundred miles away. There were other entertainments as the dedication of a new school house we had built. - a festival of the "Equal Rights Association" and many occasions of a pleasant nature that are only vaguely remembered now, but in every instance whatever the occasion we always tried to so manage the affair that it would instruct as well as amuse.

\section{Chapter Eleventh}

Religious Revivals, Etc.

One of the greatest difficulties we had to contend with in our work, was the occasional spell of madness which would attack the chief part of the community of colored people, called a religious revival. When the frenzy was at its height, all sense of responsibility in other matters became second to the one idea of saving souls.

Meetings would be held every night far into the small hours of the morning, where, not only men and women, but even little children, many not more than five or six years old, would be exhorted and prayed for, until frightened and excited, they would be led trembling and crying to the "mourners bench." Not unfrequently they would seem to fall in fits, and roll upon the floor, groaning and praying; the more ignorant the subject, the greater and more wonderful were the manifestations of a new birth. Then would follow days of "mourning," when a 
subject of these attacks would go about mechanically with sober face, speaking to no one except to answer a question or respond to a salute, and cowering by himself in some secluded spot whenever possible. This might go on for several days, or possibly two or three weeks, and then he would proclaim his conversion to the world, and relate the wonderful experience through which he had passed. Now he had "found Jesus," and was "born again—in short, he had become a "Christian."

Our pupils who became victims of the prevailing mania, would lose all interest in their studies, and possibly give up school entirely for a time, until the heat of the spiritual contest was over, when most of them would return to us, anxious to be installed in their old positions as pupils, and some of them rather ashamed of the figure they cut during the time of excitement. Before many weeks had passed, the bountiful harvest of converts would be much reduced by many backsliders. A very honest and intelligent young woman related to me the circumstances connected with her conversion. She was talking with several other girls who had passed through truly wonderful experiences. This girl - Margaret was of a naturally serious turn of mind, and anxious to attain the highest spiritual good through any source that offered opportunity and she tried to make her companions understand her feelings in this matter: with their minds so full of their own crude ideas of what religion meant they failed utterly to comprehend her views, and put their own constructions upon her efforts to explain. "O, you have found Jesus!" "Maggie's done got Religion!" etc. were the exclamations that greeted her remarks. She was dazed, and excited and submitted to be led 
by them to the "mourner's bench," and finally taken into the fold as a "lamb of God," but she always felt there was a mistake, because her quiet desire for spiritual good seemed so different from the wonderful experiences she had heard related by others.

The great mass of the colored people held very unique views as to what constituted religion. It seemed to be a subtle something which elevated its subject to the dignity of a "child of God," without in the least affecting his moral attitude towards his fellow men. There were certain acts in life which were considered sinful if committed by a member of the church, although they could bring no harm to the unconverted, as they were already as deep as possible under the "wrath of God," and no act of theirs could possibly make them more vile than they were by nature. All kinds of games were forbidden to church members, so was the singing of secular songs, but religion had nothing to do with morals. A pure, upright, honest life was not considered a necessary part of the spiritual outfit of a Christian. As is the case with most rules, this one had its exceptions, and the more intelligence became disseminated among them, the more numerous became the exceptions. The whole idea of a religious revival among the Freedmen at the time of our work there could be summed up in the phrase ["]Spiritual intoxication["].

Singing seems as natural to the negro as to the birds and all their religious exercises were varied and enlivened by Gospel Hymns, and the old plantation melodies. These latter are of unknown origin and seem to have sprung involuntarily from the brains of (shall we say?) possible poets. The words were 
usually a fervent invocation, and the music of a weird nature. I recall very little of them now only the chorus of one here and there, as

Roll, Jordan roll! Roll Jordan roll!

I want to go to Heaven when I die,

To hear Jordan roll.

or

Swing low sweet chariot,

I'm going for to carry me home.

These plantation songs became very popular from about 1870 for ten years, or so, and some of my old pupils travelled to distant lands giving concerts consisting almost wholly of these curious musical waifs. ${ }^{291}$ There were other songs written by white people often spoken of as "Negro Melodies": such as "Suwanee River," "Old Kentucky Home," "Nellie Grey," "Old Black Joe," and others, which were familiar to our ears about the middle of the 19 century. ${ }^{292}$ I remember one autumn evening in Virginia hearing a peculiar and monotonous kind of singing in the distance, and asked my serving woman what it was. "O," said she "That's a corn song. Somebody's having a corn shucking,

\footnotetext{
${ }^{291}$ Isabella and William Gibbons' daughter, Belle, left Charlottesville in 1884 to join the Fisk Jubilee Singers. The choir had organized in 1871 to raise money for the Fisk University Building Fund. The group sang in major cities throughout the Northeast, as well as throughout Europe. See. Doug Seroff, "The Fisk Jubilee Singers in Britain," in Under The Imperial Carpet: Essays in Black History, 1870-1950, editor, by Rain Lotz and lan Pegg (Crawley, England, 1986), 51. ${ }^{292}$ See Slave Songs of the United States compiled by William Francis Allen, Charles Pickard Ware and Lucy McKIm Garrison (Bedford, Ma: Applewood Books) for examples of plantation songs. Also, see Dena Epstein, Sinful Tunes and Spirituals: Black Folk Music to the Civil War Urbana: Univ. of Illinois Press, 1877); Lawrence Levine, Black Culture and Black Consciousness: Afro-American Folk Thought from Slavery to Freedom (New York: Oxford University Press, 1977); Eugene D. Genovese, Roll, Jordan, Roll: The World the Slaves Made (New York: Pantheon, 1974); Sterling Stuckey, Slave Culture: Nationalist Theory and the foundations of Black America (New York: Oxford University Press, 1987).
} 
and the men are singing the corn song." She went on to explain that when some farmers had his corn ready to be husked, it was made into a huge pile out of doors, and a few men set to work "shucking" and singing the corn song. As whiskey was always liberally served on such occasions, men and boys who heard the singing would follow the sound as the rats followed the music of the Pied Piper of Hamlin. Each one as he arrived on the scene, lent a hand to the shucking and a voice to the corn song, to say nothing of a thirsty throat to the whiskey. In this way the corn would be quickly undressed with no expense to the owner except the price of some cheap whiskey.

Returning to the subject of religion most of the Freedmen about Charlottesville professed the Baptist faith, and supported two churches, the 1 and $2 \mathrm{~d}$ Baptist. There were also some Methodists-enemy! to form a small society, which was presided over by a very ignorant colored man, well stocked with piety but sadly lacking in moral qualities. In the earlier years of our life among these people, the ministers who were supposed to proclaim the work of God from the desks of the two Baptist churches were much like their Methodist brother in character but sometime in the early seventies, each of these churches secured the services of a young man of good moral character and fair education. As the lives of the church members were so much under the influence of their minister, it was quite a step in the right direction for them to secure religious leaders who really 
influenced them for their good, and consequently no little help and

encouragement to us-as one can readily believe. ${ }^{293}$

In the celebration of marriages, and the conduct of funerals, the ex-slaves took their cue from the white people, and aped their manners, and style of dress etc. as far as they were able. They often spent large sums which they could ill afford, to procure the clothing and food they considered necessary for a reasonable display on such occasions, and, perhaps, nearly starved for weeks afterward to make up for the unusual outlay: but, perhaps, in this they were no worse than many people of white skins, and a better opportunity to judge between what is necessary and proper, and what is simply foolish extravagance.

One of the superstitions of the more ignorant of these people was the fear of being "conjured" which meant the same as what is more commonly called "hoodooed." Whether the belief in this peculiar from of the black art was common among the people of Charlottesville I am unable to say, as I seldom heard the subject mentioned except now and then among our pupils as a matter for a joke; but enough was said to show that there were some who believed that evil minded persons could often exercise some supernatural power for ill over those who were so unfortunate as to offend them.

The ex-slaves were every whit as fond of creature comforts as their white neighbors. "Good eatings" and warm rooms were very essential to their happiness. Good, well-fitting clothes were also necessary to the more intelligent,

${ }^{293}$ The white Baptists and Methodists in Charlottesville had actively evangelized among the black population since the early eighteenth century. See Woods, Albemarle, pp 79-80. 
while cheap finery and yew-gaws filled all the requirements in this line for those of a less intelligent sense of the fitness of things.

Many of the colored women and girls would wind pieces of twine around locks of their woolly hair making it stand up all over their heads like little tails. The process was called "wrapping" and was done to straighten it in a measure and really served to take out some of the Kink, so that on dress occasions they could arrange their locks more after the manner of white people. ${ }^{294}$

With a wonderful intuition as to what was becoming in dress, those of very dark skins usually affected bright colors - red and yellows predominately - while those of lighter or very fair complexions were apt to select softer shades of color. However the style and color of their dresses was as always a matter of choice with them, as some poor creatures never knew what it was to have an article of clothing made expressly for them, but had to consider themselves happy if made comfortable in the cast off apparel of others more fortunate, and in such cases the question of color was necessarily second to the greater question of comfort. $^{295}$

Any thoughtful, unprejudiced person could not have lived among these people very long, without percieving that all the seeming absurdities in dress, religion, etc. were the efforts of a people to adapt themselves as best they could to the

\footnotetext{
${ }^{294}$ The literature on hair as it relates to public image is growing. For the most current resource in public history see Hair in African Art and Culture edited by Roy Sieber and Frank Herreman for the Museum for African Art (New York).

${ }^{295}$ See Lydia J. Ware's dissertation, "Dress of the African American Woman in Slavery and Freedom, 1500-1935" (Purdue 1981).
} 
circumstances by which they were surrounded, and a reaching our for "something better than they had known."

\section{Chapter Twelfth.}

Incidents of Travel.

In looking over old diaries, I find, under date of July 8th 1867 this item. "On my way from Virginia I rode from Washington to New York in the car with Gen. \& Mrs. Grant." This was the only time I ever saw Gen. Grant except on the day of his Inauguration March 4 1869. At that time I had been teaching in Charlottesville three years, and went to Washington accompanied by Mrs. Isabella Gibbons one of our colored teachers. Her husband was a Baptist preacher and presided over a church in that city, so, through him we secured accommodations for a few days. I did not attempt to witness the inauguration ceremonies but saw the procession from the Treasury Building, from which spot I waved my handkerchief, to the Incoming president in return for the bow with which he saluted the group assembled there. After the procession, (which was very long) had passed, we went to the Capitol, and Mr. Gibbons who was familiar with every part of it, took us well over the vast structure. Although I had seen the main part of the building before, I had not been in the basement, so this was quite a revelation to me with its restaurants, barbershops etc. etc. Returning to the main floor, Mr. G. spied a page hastening toward the Senate Chamber with a message. Said he "That boy has a list of the names of the new President's 
Cabinet. We'll see who they are," saying which he stopped the page and asked to see the list. So we got ahead of the U.S. Senate that time. We went on to the Senate Chamber, however, and heard the news read to that august body. I stayed in Washington three or four days at that time, and while there heard "Blind Tom" the musical wonder, visited Charles Sumners' house, the navy yard, Smithsonian Institute and other places of interest. ${ }^{296}$ This was not my first visit in Washington, however, as in July 1867 Miss Gardner and I stopped over for a day, on our way to Charlottesville at the Hotel of Mr. Joy, corner of $8^{\text {th }}$ and Pennsylvania Ave. Mr. Joy was a Massachusetts man, and upon learning that we were Freedmens teachers exerted himself to make our visit there pleasant. He introduced us to Mr. \& Mrs. John Jollippe. Mr. Jollippe was a Virginia lawyer, a Quaker by birth, and an old time abolitionist. He was the lawyer who defended Margaret Garner, the slave mother who killed her two little daughters to save them from the fate she knew awaited them in slavery. He was very much interested in our work, and opened a correspondence with us in regard to it. He had a good deal of influence in Washington, and offered to get us positions in the schools there, or if we preferred, in some of the departments, but we were too much interested in our work in Virginia to consider any other position however advantageous it might be. Mr. Jollippe died, at an advanced age, a year or two later, and was followed to his grave by a procession which included a large part of the colored population of the city.

\footnotetext{
${ }^{296} \mathrm{Blind}$ Tom, a celebrated pianist and composer, was born in bondage in 1849. He was named Thomas Bethune and sometimes called Thomas Wiggins. He died in 1908. See Blind Tom by Rebecca Harding Davis, Electronic Text Center, University of Virginia.
} 
It was on the visit above mentioned that I had the good fortune to meet a young gentleman from Boston, whose name I have most ungratefully forgotten, but who acted as my escort to all the principal places of interest in the city, and it was with him that I made my first ascent up the dome of the Capitol. -- a feat I accomplished two or three times afterward. He took me around to Fords Theatre where President Lincoln was shot, and pointed out the house where he died, as well showing me the patent Office, Smithsonian Institute and Treasury Building. We stopped at Mr. [unclear] once more - the following year, I think - and went into both Houses of Congress, which was in session at the time. I remember hearing Charles Sumner say a few earnest words, but do not now recall the matter under discussion. I saw Ben Butler in the House. The relations between President Johnson and the Congress were very much strained at the time. Miss G. and I wished very much to attend one of the receptions at the White House, but our feelings toward Mr. Johnson were none too kindly and we could not make up our minds to shake hands with him, while we would not commit so unpardonable a breach of good manners as to follow the example of some, who, we were told, deliberately insulted the President by refusing his proffered hand when introduced. No act of his could be an excuse for such discourtesy, for no one, unconnected with affairs of the government was compelled to meet him. He undoubtedly acted up to his own idea of what was right, and should, at least, have been accorded the consideration due to the President when met at a public reception. 
I have always regretted that I never took the trip to Mt. Vernon which I could easily have done by stopping over an extra day in Washington, but I postponed it from time to time until the opportunity slipped away, as opportunities have a habit of doing, unless we sieze them as they halt before us.

Early in 1868 a Convention for the purpose of framing a new State Constitution preparatory to readmission to the Union was held at Richmond. ${ }^{297}$ Two delegates - both Republican - were sent from Charlottesville. Mr. Thompson, white, a printer, and an old friend of Garrison, and James T. T. Taylor, colored - a former pupil in my night school. Naturally Miss Gardner and I were much interested in the work of this convention, so, on Feb. 27 we went down to Richmond for a few days. Mr. Thompson secured board for us at the Monticello House where he was staying. He with a friend of his, also a delegate, met us at the station, and asked us if we would like to attend a political meeting to be held that evening in the Convention Hall at the Capital. Judge Rives of Charlottesville Mr. Underwood, and John Minor Botts were to be the principal speakers. Of course we accepted the invitation gladly. After supper, Mr.

Thompson came to us and said that he had learned that there would probably be no ladies present, and possibly we would not care to go under such circumstances but Miss Gardner assured him it would make no difference to her, if he and his friend did not object to taking us there. Of course they proffered to be more than willing, and equally of course, I felt all right to follow Miss Gardners lead, so we went and listened to bright and witty speeches from Mr. Underwood

\footnotetext{
${ }^{297}$ The state constitutional convention met in Richmond from 3 December 1867 to 16 April 1868.
} 
and Mr. Botts, and an exceedingly eloquent and delightful one from Judge Rives. There was just one other lady present on that occasion, the wife of one of the delegates. We felt that she was, probably glad that we were there to keep her in countenance, although she was probably, like ourselves too independent to mind it much. There was one other delegate, with whom we had a slight acquaintance - Lieut. Fred. Poor from Gordonsville. He recognized us and came from his place in the hall to greet us. We enjoyed the speeches much, and were very glad we went.

On the following day we visited the school taught by Miss Bessie Canedy who was an old friend of Miss Gardner's and in the afternoon we attended the Convention at the Capitol.

Feb. 29 we visited Libby Prison, attended the Convention, and called at the Teachers Home. In this Home were some with whom we had become acquainted, viz Miss Abby Francis of Cambridge, a niece of Lydia Maria Child, and the Misses Bell and Miss Harriet Buttrick of Concord. ${ }^{298}$

March 1 Sunday. Attended Jeff Davis Church (Episcopal) in the morning and dined at the Teachers Home by invitation. ${ }^{299}$

March 2d. went out to Gambill Hill, visited several schools, and attended the Convention. This wound up our trip to Richmond as we returned to Charlottesville the following day.

${ }^{298}$ Teachers from throughout the Northeast were working in Richmond under the auspices of several freedmen's aid societies. See Ronald E. Butchart, Northern Schools, Southern Blacks, and Reconstruction: Freedmen's Education, 1862-1875 (Westport, CT: Greenwood Press, 1980).

${ }^{299}$ Jefferson Davis attended St. Paul Episcopal Church. During his lifetime the church had balconies for its African American members. St. Paul's is also the church where Patrick Henry made his speech for freedom. 
I had an interesting experience beginning with Sept. 29 1870. I was on my way to Charlottesville, and when the train left Washington that morning it was raining heavily. Occupying the seat with me was a refined appearing lady of seventy odd years, whom I afterwards learned was Mrs. Mary S. Livermore of Cambridge. ${ }^{300}$ Travelling in company with her were Mrs. Lewis, a young woman from Tennessee, with her little son six years old. Mrs. Lewis had been visiting in the North, and Mrs. Livermore was going on to spend the winter with her. I learned these facts from the conversation that passed between the two ladies, as Mrs. Lewis and her son sat directly in front of us.

The rain continued to fall in torrents through the forenoon. We reached Gordonsville about mid-day, where trains usually halted half an hour or so for lunch. But the half hour extended to an hour - two hours - and other trains arrived - this being a junction - and still we stayed on. Finally the word got round among the passengers that there was a great flood on the streams ahead of us, and the bridges were either unsafe or entirely swept away. There was nothing to do but to make the best of it, and the passengers who did not care to leave the train for the hotel, resorted to all sorts of expedients to make themselves comfortable for the night. Whenever the harassed conductor came into the car he was besieged with questions which he was unable to answer

\footnotetext{
${ }^{300}$ Mary S. Livermore (1850-1905) was unequivocal in her commitment to women's suffrage. She called to order the first women's suffrage convention ever held in Chicago. Consequently she was elected president o the Illinois Woman Suffrage Association. Although the Illinois Constitutional Convention ultimately rejected women's suffrage, the legislature did enact married women's property legislation in 1869. For the first time, married women could control their own wages and hold title to real estate Born in Boston in 1820, she met and married a Universalist minister, Daniel Livermore, in 1845; they had three children. In 1861 Mary organized the Chicago branch of the U.S. Sanitary Commission. In 1863 she and Jane Hoge, a colleague, organized the Great Northwestern Sanitary Commission Fair. She published her memoirs in the 1890s.
} 
satisfactorily, and the hotels were besieged by hungry travellers for food, which it strained their resources to provide. There was a terrible onslaught made upon the poultry yards to appease the appetites of so many hungry people. Happily for me, I had plenty of food still in my lunch basket, which I shared with Mrs. Livermore and her companions. We made acquaintance rapidly under the unusual circumstances, and Mrs. Livermore became a lifelong friend. The train remained stationed there that night, and until late in the afternoon the following day when it moved on about sixteen miles to a small place called Shadwell which was only four miles from Charlottesville, but between us and my destination two bridges had been swept away - the one across the Rivanna river, which we struck at Shadwell and the one across Moores Creek over Charlottesville. The Rivanna, usually a tiny stream, which could, at times be crossed in some places on the stones in its bed, was now a raging, seething torrent. As it was impossible to proceed with the train, it was decided to take it back to Washington. Previous to this, however, the conductor had returned to me the last coupon of my ticket, saying he thought it unlikely that he should be able to see me through to my destination. I still keep it as a souvenir of that memorable journey. In the meantime I had learned from the conversation I could not avoid hearing that passed between Mrs. Livermore and Mrs. Lewis, that they were without money to meet such an emergency as we had met. They had through tickets and their baggage was expressed through, and Mrs. Livermore had her bank books, and some jewelry of value, but they had less than five dollars in money between them. Mrs. Livermore was a feeble old lady, and Mrs. Lewis was in no condition 
to contend with extra hardships in travelling being within a month of her

confinement. Fortunately I had a good supply of money with me, as the Society in Boston had advanced me two months salary besides my travelling expenses, so I had over a hundred dollars on hand, therefore I offered them the loan of ten dollars, which they gratefully accepted. I also invited them to stop with me in Charlottesville when we got there until they could resume their journey for we soon learned that the flood was quite extensive and travel by rail between us and Tennessee was impossible, so they were very glad to accept the offer of a shelter under my roof and when it was announced that the train was to return to Washington, Mrs. Livermore went out to a nearby house and asked the woman who occupied it if she could keep us over night which she readily consented to do; so we took up our hand baggage consisting of travelling bags, lunch baskets, wraps and a basket containing pots of small plants which Mrs. Lewis was taking home with her. Our exodus was not unnoticed, some fine gentlemen put in an appearance and asked for lodging. Our hostess evidently considered it the part of wisdom to "make hay while the sun shines" so she agreed to take them. The establishment was not a large one. The main house consisted of two good sized square rooms, in the rear of which was the kitchen, separate from the house as usual was at that time in Virginia. Our hostess, with the help of a colored girl, prepared us a very good and substantial supper, which if I remember rightly, we ate in the Kitchen, and then came the preparations for the night. The four gentlemen occupied what I suppose was the living room, camping as best they could on the floor. In the other room was an old fashioned ordinary bed, which 
Mrs. Livermore, Mrs. Lewis and myself were told we were to occupy. We partially undressed and threw ourselves upon it crosswise. On a low chest was made a fairly comfortable pallet for Mrs. Lewis' little boy. Our hostess had five children of her own. She reserved a trundle-bed, which she drew from beneath the larger bed, for herself and her youngest child. For the others she would throw down a mat or a woolen garment, and point to one of the other four to lie down upon it. Each one would obediently curl himself upon the spot indicated by her gesture, and all of them remained quiet through the night, as I can testify for I slept very little myself. The comical side of the position in which we found ourselves presented itself with so much force that I was shaking with smothered laughter a good part of the night. It was so ludicrous - ten of us in one moderate sized room spread about very much like sheep in a pen-a most unique experience, and as I was young and well, and not far from my destination I could enjoy the strangeness of it all, but I doubt if it seemed as funny to Mrs. Livermore and her friend with no money, and still a long journey before them. In the morning we had our breakfast and settled with our hostess, and then looked over the situation. The river had settled a little, but was still a whistling mass of water. The four gentlemen had disappeared, and we were told that they had crossed the river. I said if they could get across we could do the same, so we applied to a colored man who had a boat to take us over. He agreed to take us one at a time but would not attempt to carry us all at once. I went first, and when well out in the stream the boat got pretty giddy; but I was landed safely in a tobacco field, which the day before had been under water. Anyone acquainted with the nature 
of Virginia soil, will understand the luxurious softness of the ground beneath our feet after we were all safely landed. We made tracks-and pretty deep ones, too - for the nearest house which belonged to a well-to-do gentleman named Smith, where, we had been told we might procure horses to take us to Moores Creek. We were kindly received and urged to remain until we could proceed on our journey in comfort, but I was too near home to be contented to stay and my companions were as eager as myself to get on to Charlottesville, so Mr. Smith sent a man to ascertain if horses could go to the Creek. He soon returned with the discouraging news that there were so many gullies washed out, that travelling on horseback would be impossible. So thanking Mr. \& Mrs. Smith for all they had done, and all they had tried to do for us we set out on our pilgrimage of two and a half miles to the Creek. We were accompanied by a colored man and woman and a boy and girl some twelve or thirteen years of age. They carried our hand baggage, and assisted us in any necessary way. I suppose these helpers were sent with us by the Smiths, but do not now remember whether that was the case, or whether we had engaged the man, and the others had volunteered their assistance. Any way we could hardly have got along without them. We did not make any special effort to follow the road, which gave us no better travelling than the fields. We [unclear] to get our feet entangled in the telegraph wires (the poles having been thrown down by the flood) as well as other obstacles, so we chose the easiest walking, whether highway or field. My chief anxiety was on account of poor Mrs. Lewis, who would frequently drop deep down and declare her inability to proceed. At such times, while Mrs. Livermore sat by her to 
encourage and comfort her, I would hasten on a little way and then return, to assure them that the path before us, was much better than that we had already travelled, and so encouraged and a little rested she would face the inevitable and press on once more. We would frequently come to ditches or gullies five or six feet wide, and as many in depth. In such emergencies, the man who accompanied us would bring a rail from a nearby fence to form a slender bridge which we would cross by clasping hands - the man at the head of the chain, and sidle across. I do not remember how many such bridges we traversed.

Sometimes we would have to climb a steep bank - pulling ourselves up by the vines and bushes growing there. At one place I found I had assisted myself by clinging to the vine of the poison oak as it is called in Virginia - better known here as ivy, but, luckily I experienced no ill effects from it. We were thankful enough when we came in sight of Moore Creek - the last obstacle between us and Charlottesville - and a mud be-spattered, dilapidated looking crowd we were. They had constructed a ferry across the Creek, so we crossed easily to the Charlottesville side. A man was waiting there, with a rough wagon, who wanted to take us into town, and my companions were in favor of employing him, but I said most emphatically "No! We have had a hard journey so far, and will finish it in comfort." and seeing a colored boy who belonged to our schools loitering about there I sent him to town for a carriage "the best one in town" was the order. I then took my tired friends to the house of a colored woman I knew to await its arrival. She made Mrs. Lewis lie down, while she prepared tea for us, and did all she could for our comfort. By the time the carriage arrived, all were much 
refreshed, and in a better condition to finish our journey. As we rode through the principal street of the town, we passed two of the gentlemen who had lodged in the house with us at Shadwell. They recognized us and raised their hats and Mrs. Lewis expressed her gratitude that I did not consent to taking the shabby vehicle we saw at the Creek. She had not supposed that Charlottesville was so large and important a place. When we reached my Virginia home, I had Miss Gardners bed chamber put in order for Mrs. Lewis and her little boy, and Miss G. had not arrived and I knew she could not reach the place until the roads were passable. A bed was made each night on the couch in my sitting room for Mrs. Livermore. They remained by guests for a week, when learning that a freight train was about to try to pass down their line, they decided to get passage on it if possible. Chairs were carried out to the junction of the two roads near the school house, and there they sat with their few belongings about them for hours, not daring to leave for fear the train would come along, and knowing it would only wait to change the switch. It finally came, and they were helped into a car and rode on-as we afterwards learned, into greater hardships and more difficulties than they had experienced before. Sometimes they rode on hand cars, and sometimes they had to walk for miles between conveyances. The money I loaned them purchased food and paid for lodgings here and there. People were kind to them seeing their pitiful condition, and after several days of this uncomfortable pilgrimage, they reached Mrs. Lewis in Tennessee. I heard from them as soon as they could possible write me, and they returned the ten dollars promptly. Miss Gardner arrived the day they left. One of my trunks reached me 
in about a week, and the other some days later. I considered myself fortunate to get them at all. This storm was always spoken of afterwards by the colored people, as the time of the "great fresh" meaning freshet.

\section{Chapter Thirteenth}

Incidents About Home.

I have related in a previous chapter that our first home was in a large brick building called indifferently "The Mudwall" or "The Delavan." This building had been used by the Confederates for a hospital, and so came under the jurisdiction of the U.S. Government, at the close of the war. Sometimes in '67 or '68 the property was ceded back to the original owners, and we had living rooms fitted up for us in the building used for our schools. A colored family named Poindexter had occupied some of the lower rooms in Mudwall, having acted as servants in Major Head's family while the military were there. ${ }^{301}$ This family hastened to secure a home elsewhere as quickly as possible, but it was necessary for Miss Gardner and myself to remain until our rooms in the school building were ready for us to occupy. Miss Gardner felt that it wasn't quite safe for us to be entirely alone in this big building at night, so a young man who attended my evening school, volunteered to sleep in one of the lower rooms to act as a guard, or be called upon in any emergency. He was a tall strong fellow-quite black, and had been a soldier in some one of the colored regiments. He was very anxious to

\footnotetext{
${ }^{301}$ See Joseph C. Vance's thesis "The Negro in the Reconstruction of Albemarle County" (University of Virginia 1953).
} 
learn, and used to spend his evenings while guarding our postals in studying his "Second Reader" I do not now recall his name.

One evening there was to be some Kind of a political meeting among the colored people, so he asked us if we would mind if he did not come in until about 10 o-clock as he wished to attend the meeting. We assured him that it would be all right, and we would sit up until he came and let him in, so we barred the doors securely and went to our separate rooms, to read or write. Sometime between 9 and 10 Miss Gardner came to my room in a state of great trepidation declaring that she had heard some one walking about in the rooms down stairs. I felt sure that it was her imagination, but said I would go down and see, so I took my lamp and went down, the remaining lamp in hand at the head of the stairs as a sort of rear guard. I searched three of the rooms on the left of the hall without success, and then as I started for the large room at the right, I heard a slight sound and felt sure the intruder was in there. It seemed anything but a pleasant duty to go in, but I thought if danger was there it was best to put on a bold front and meet it half way rather than to wait for it to creep upon us, so I went in - a little shaky, I must confess, but determined to ferret out the cause of the sounds we had heard. I looked all about the room, behind the big pillars, and in the dark corners. There was nothing there to produce any kind of a sound. There was still one more room at the immediate left of the front door, and as I came back into the hall, I heard a slight noise in that direction. I started to go in when a hearty laugh at the front door stopped me, and I saw our guard looking in through the side light You can imagine that it was with a sense of relief that I unbarred the door and 
admitted him. It happened that the meeting closed some what earlier than he expected it would, and it was his step upon the piazza, and knock at the door that Miss Gardner had mistaken for noises in the rooms below. He saw me come down the stairs, as he supposed to let him in, and could not, at first, understand why I went hurrying from room to room instead of opening the door. But when I came out of the large room, and started for the one near the door, the truth dawned upon him, and the comical features of the situation struck him so forcibly that he laughed aloud - the best think he could have done, as nothing else could have swept away the creepiness of the situation so promptly as did that merry, hearty laugh.

I have mentioned in a previous chapter some of the annoyances we suffered from the students breaking our windows etc. and I will here relate another of their escapades as it seems to fit into this chapter. The incident occurred several months previous to the one just related while the Poindexters still occupied their rooms on the lower floor. The front door opening on the piazza usually stood open until quite late, and one evening some students passing up the railroad track, bravely "bearded the lion in his den," by rushing into the hall stamping and swearing like demons. Evidently their purpose was simply to frighten us, but knowing the reputation many of them bore, we could not be sure that no harm was intended. Miss Gardner hastened to my room and begged me to lock the door, which I did at first, but as the noise and racket continued I could not endure to remain inside, so I went out telling her to lock herself in if she chose, but I preferred the freedom of the large halls and many rooms to dodge about in if 
there were any real danger, and I wanted to see just what they were doing; so I placed myself at the head of the stairs, where I was in the dark, and could see them jumping and kicking about in the hall below, the open door giving light enough for that purpose. "Come on up stairs! Come on! Lets go up stairs!" I could hear one of them say but no move was made to do so. Had they started to come up, it was my intention to speak, and if possible, halt them at once. Some of the colored people had told them to be very careful how they disturbed us, as we each had two revolvers and knew how to use them. This was a fairy tale, but it might have had its weight, for, of course, had it been true, we should have had a decided advantage, standing at the head of the stairs in the dark, while they were exposed from the light through the open door. However they made no move to come up, and much to my relief, they soon went away. I saw as they passed through the door that there were four of them. I remained at the head of the stairs a few minutes, then started to descend to look up the Poindexters who had vanished completely, when several colored men walked in, armed with sticks and I knew not what other weapons. They had a meeting at the church that night, and some of them hearing the racket at our house, and mistrusting the cause, came to our assistance. Mrs. Poindexter and her daughter now came from their places of concealment, too frightened to know what they were talking about, and disposed to make their story as terrifying as possible. "How many were there?" asked the leader of the rescuing party. "O!" said Mary Poindexter "There were more than twenty!" “O, Mary!” said I “Don't exaggerate. There were just four. I counted them as they passed out." This was the only time that any 
students ever entered our house in this way, although as I have said before they did not hesitate to stone our windows without the slightest provocation, and one night a party of them called at our house very late in the evening and wanted to see the teachers. Paul Lewis and his family occupied rooms in the house at the time, it being after we had moved from the Mudwall into the school building. The doors were securely fastened, and he did not open them telling them, that they could not see us as we had retired, which was true. They professed to disbelieve him and declared they would see us, and began pummelling the door. Lewis armed himself with a gun, and an old sword and awaited their next movement. After pounding awhile, they fired a pistol, and departed. They were probably under the influence of liquor.

It was while we were living in our second home, the Confederate hospital building, that the following incident occurred. There had been some new desks made for Miss Gardners school-room, and, one day, after school hours, she was giving directions to the colored carpenters as to how they should be placed, etc I was with her watching the progress of the work, when a white man walked unannounced into the room and seated himself near Miss Gardners desk I had never seen a pirate that I knew to be such, but were I an artist, and wanted to make an ideal picture of one, I would be willing to pay that man a good salary to pose for me long enough for me [to] copy the ferocious expression his countenance wore that afternoon. With the regulation dress and accouterments of a pirate as usually pictured, and a flag bearing the skull and cross bones, he would be perfect. Even with the peaceful background of a school-room for a 
setting, no one could fail to note the resemblance. He commenced the conversation by asking Miss Gardner various questions about her school etc questions which I do not now remember, and to which Miss G. made very brief replies, such as would not tend to encourage him to prolong the conversation. Perceiving this he said "I am not asking these questions out of curiosity." "Is it because you are interested in our work here?" queried Miss Gardner. His reply as near as I can recollect was something like this, "I think this country was made for the white man, and the white man is going to rule here" and much more of a similar nature. Then turning to the carpenter he addressed him "What do you think of a white man, anyway?" The man, a little confused and startled repeated his question. "What do I think of a white man?" "Yes," said our visitor. "What do you think of a white man?" Miss Gardner interfered with a reply. "He thinks a white man is just as good as a black man as long as he behaves himself." "You think that, do you?" said our visitor, still addressing the carpenter. Between the man's loyalty to Miss Gardner, and his fear of offending his questioner, he was evidently in doubt how to answer, but loyalty prevailed and he said, "Well, yes, I think so." Upon hearing this Mr. Pirate turned fiercely toward us. "You mark my words, "said he. "There will be a tragedy enacted here sometime. There will be a tragedy enacted here." He then walked out with as little ceremony as he had entered. I told Miss Gardner we seemed to be having the comedy in advance of the tragedy.

I think that what I am now about to relate occurred in the fall of 1872 . We were occupying the building that had been erected on purpose for our schools Miss 
Gardner had left Charlottesville, and Miss Holmes was my associate in the school. Our rooms were up stairs above those of the janitor whose wife, Margaret, did our work. One evening after tea Miss Holmes was sitting with me while Margaret was finishing up the work in her room. Presently she came to my door and said, "Miss Annie, have you locked up any of the scholars in your school-room? I can hear some one snoring in there." We all went to the schoolroom, not knowing but some child might have fallen asleep and been overlooked, but everything was still there. We then went into the front hall, and could hear the snoring distinctly. It was after dark and Margaret brought a light when we discovered a man stretched on the three lower stairs, evidently in a drunken slumber. I called down to him and asked him who he was and what he was there for. His reply was “It's me, Mary-George Lincoln - it's me!” I spoke tọ him several times telling him we wanted him to go away, and Margaret called down to a young girl who was calling at her rooms to tell Paul to come. The girl shouted back, "Paul isn't at home!" There was no other way to go up or down stairs, and it was necessary to have him moved as soon as possible, so I said "I am going down to stir him up" and suited the action to the word. Margaret followed me, and Miss Holmes held the lamp for us at the head of the stairs. I managed to push by him and open the door at his feet, and then taking a position on the step above him, I spoke rather sternly, telling him we wanted him to get up and leave the house at once. He seemed now to wake up to a realization that some move was being made to disturb him. Slowly and surly he rose to his feet and confronted us. "I want-to-see-the-landlord-of-this-hotel," he growled. "I am the 
master of this house, and I want you to go," said I. He looked at me a moment and then began slowly feeling in the Jacket of his coat, whether for a pistol or his card I never knew. "Let-me-just-show-

you--" "No!" I said throwing my hand toward the open door, and putting my foot down as emphatically as I knew how. "Go!" He went out as if he were thrown out - propelled by the sheer force of anothers will - hypnotized - one might say for the moment. As we fastened the door of his exit he hastened round to the one at the other side of the porch but Margaret was too quick for him. Finding that locked he started for the rear of the house, but Margaret got there first and locked that. He had but one arm - in fact we discovered when he rose to his feet on the stairs In relating the circumstance to some of my pupils who came that evening for a lesson, Margaret said "Why, Miss Carkin took him by the collar and kicked him out!" And I have no doubt that in her excitement she thought so, but the only force I used was that of a determined will, backed by the feeling that I was equal to the emergency.

\section{Chapter Fourteenth.}

\section{Little Trips Outside Charlottesville}

I have always regretted that I did not take the opportunity to see more of Virginia while residing there. It would have been an easy matter to have visited Mt. Vernon when passing through Washington but each time I went back and forth there would seem to be some cause to hasten on, so I would wait for the convenient time which never came. Lynchburg was only some fifty miles from 
us, and the wonderful Natural Bridge about the same distance I think. Weir's Cave was another interesting natural curiosity we neglected to see, and we never visited the historical towns of Fredericksburg, Petersburg and Norfolk to say nothing of many other places of interest. I look back now to the indifference that allowed such an opportunity to have laid up treasures of memory with one great, big regret, that we allowed ourselves to become so absorbed in our work that we rarely left Charlottesville to go anywhere.

While there were schools under the auspices of the Freedmens Aid Society at Gordonsville, Orange Court House, and Louisa Court House, we did stray so far from our own fold, as to visit the Northern teachers at their places occasionally but the visits were few and far between. When I went to Charlottesville, Miss Jane Holmes of Concord Mass, and Miss Harriet Stone of Keene, N.H. were teaching at Gordonsville, and these being our nearest neighbors - only twenty miles distant - several visits passed between us. Owing to inconvenient railway communication between these near by places, we usually spent the night with the friends we visited. Otherwise it would be necessary to return to our homes in the middle of the night. Notwithstanding the inconveniences we made as many as three or four visits to Miss Holmes and Miss Stone while they were there. I remember the first time I visited them, the three of us slept together in one bed. On one of my visits there Miss Holmes was alone. I do not now remember how it happened that Miss Stone was away, but owing to her poor health she may have returned north earlier than usual. In the morning Miss $\mathrm{H}$. and I rose early, and took a train on the Virginia Central railroad to visit Miss Lucy Chase at Louisa 
C.H. We arrived in season to breakfast with her, and she was as delighted to see us as a lone woman in a lonely place could be to see friends from outside. Her stock of table ware was limited to just what she must have for herself. One of us drank our coffee from a cup and one from a mug. To one of us she gave her Knife and the other had a fork. I have forgotten how the one teaspoon was shared, but we had a delightful visit and a jolly time, in spite of a shortage in china and silver. After Miss Holmes and Miss Stone left Gordonsville, Miss Martha Chase of Providence R.I. taught there for a year I think and a niece of John E. Whittier was with her a short time. Miss Gardner and I visited Miss Chase once. Miss Holmes succeeded her and Miss Stone returned as Miss Holmes assistant and I made them one or two visits. In 1871 I think, this school was discontinued.

I once visited Mr \& Mrs. John W. Pratt, who with their young son, were at Orange C.H. a short time. I remember very little about this trip except the fact of my visit there, that one time.

In looking over some old Freedmens Records for data, I find I made a mistake in speaking of Miss Harriet Stone as of Keene, N.H. Her home was Chesterfield, N.H.

I have forgotten in what year I made a trip to Staunton in company with Miss Mary Scott, eldest daughter of Robert Scott, one of the leading colored men of the place. He had always been free, and was in very good circumstances, being in great demand as a musician. Miss Scott had friends in Staunton and invited me to accompany her there. We made the trip in late October, and the ride 
across the Blue Ridge Mts. was delightful, with the exception of one mile through the tunnel. The foliage was in all its autumn glory, and looking down from the heights the eye could take in miles of the most beautiful color imaginable. I say a marked difference in the streams on the two sides of the mountains. On the eastern side the water was very muddy, from the nature of the soil which is a reddish clay. After crossing the mountains we found the water clear and sparkling like our streams in New England.

We went to Staunton on Saturday and returned the following Monday, so I had Sunday in which to see a little of the place. My most vivid recollection is of a visit I made to the U.S. cemetary for Union soldiers, which was about a mile from my stopping place. The day was cold and raw and we had a rough walk, but I would not have missed going even had the difficulties been much greater I do not remember the number buried there but it must have been many hundred for the cemetary was a large one. The graves were arranged in regular rows each with its white head board, lettered in black and very many of the graves bore only this inscription "Unknown Union Soldier" with Co. and Regt. This brought home to me in all its force the fact that there were many families mourning the loss of dear ones, whose fate was all unknown to them, and of whose last resting place they had no knowledge.

Of course we made a good many trips to Monticello (which place I have described in a previous chapter) this being the most interesting spot in the vicinity to our occasional visitors, but what I have related covers about all that we made 
any attempt to see outside Charlottesville in the nine and a half years I was there. 


\section{Appendix II}

\section{Reports on Prominent Whites and Freedmen ${ }^{302}$}

In May 1867 Bureau agents were asked "to report the names of six or more white citizens, residents of the county, and six of the most intelligent of the freedmen, in whom both races have confidence." 303 Following are the individuals identified by the agent in Albemarle County. "During the war there were very few really loyal men in this county, and all such are not qualified for the discharge of the duties of magistrates. But of these men I am unable to give much information touching their politics before the war.

George W. Dillard was a Union man throughout the war, and on two occasions well nigh lost his life for his opinion's sake. Once, but for a timely escape, he would certainly have been hung. I am informed that he was for many years a Whig, and afterwards a Douglass Democrat. He resides at Scottsville, which is his post office.

Orville Allen, formerly an extensive slave holder, was also a Union man during the war. I am not personally acquainted with him, but he is said to be a man of excellent qualifications for the office of magistrate. He was formerly a Democrat. He resides at Earlysville, which is his post office.

Thomas J. Savage was also a friend of the Union during the war. I am told that his life was once or twice threatened and endangered. He is an elderly

\footnotetext{
302 Bureau of Refugees, Freedmen, and Abandoned Land, Reel 67, Records of the Assistant Commissioner for the State of Virginia, 1865-1869, accession 30080. "Reports of Whites and Freedmen Recommended for positions of Trust and Responsibility, 1867.

${ }^{303}$ The Freedmen's Bureau Assistant Commissioner for Virginia, Brevet Brig. Gen. Orlando Brown. March 8, 1867, Letters and Telegrams Sent, Bureau of Refugees, Freedmen, and Abandoned Lands, 1865-69, Library of Virginia.
} 
gentleman, but possesses a good constitution and a strong mind. He was formerly a Clay Whig. His residence and Post Office is Charlottesville.

Henry O. Austin, a retired physician, and a large landholder on the Rio River, was also a Union man. He was not known in past times as a politician, but is said to have been a Clay Whig. He resides about six miles north of Charlottesville, which is his post office.

John R. Woods, whose resident and post office is Ivy Depot, a large land holder, and formerly a large slave holder, is also a retired physician. I believe he was in favor of secession and rebellion, but is now zealous for acceptable reconstruction. He was formerly a Clay Whig. He lives seven miles west of Charlottesville.

Henry Benson, of the firm of $\mathrm{H}$. Benson, \& Bro, was, until recently, an alderman of this place, and one of the very best magistrates in the county - prompt, fearless, and impartial. He was formerly a Democrat, and during the war favored rebellion, but now urges acquiescence and acceptable action. He resides in Charlottesville.

Nathaniel H. Massie, President of the Charlottesville Bank, was made a magistrate during the war, and continued on until November last, when he resigned, that he might give more attention to his business. He was formerly a member of the Freedmen's Court, selected by the colored people, and gave (unclear) satisfaction. If he would serve, he would make a most acceptable magistrate. He is not a politician, but is said to have been a Clay Whig. His residence is in Charlottesville. 
William T. Early, Esq., a retired counsellor at Law, was regarded during the war as a Union man, though under the act of conscription compelled to take part in the Rebellion. I believe he commanded a company of Home Guards. He was a large slave holder, but a humane master. He was a Clay Whig. He, too, if he will serve, would make an acceptable magistrate. He resides two or three miles from Charlottesville, which is his post office.

Charles D. Everett, formerly a physician of Philadelphia, but for some years past a resident of Virginia, having inherited a large estate which he now possesses, resides in the eastern part of the county, near Keswick Depot, which is his post office. He was a friend to secession and rebellion, but is esteemed by all classes as a most worthy gentleman. He was formerly a Clay Whig.

Most of the gentlemen of highest respectability in this county are disqualified to hold office under the law, on account of offices which they formerly held under the government of the United States. This applies in some instances to devoted Union men.

Among the colored people in this county there are very few who have intelligence beyond their ordinary avocations, and still fewer who have any education. And upon inquiring I find the most intelligent are not in all cases the most influential.

Robert Scott, an octoroon, is a musician. He has always been free, owns considerable property, and reads and writes. He mingles but little with either race, but is by both highly esteemed. He resides in Charlottesville. 
Nicholas Rickmond, a quadroon, is a shoemaker. He has always been free. $\mathrm{He}$ is also a Baptist preacher, and is highly respected in the community. He reads and writes. He is intelligent, and exercises considerable influence among the colored people. He resides in Charlottesville.

William Gibbons, a mulatto, is a farmer, and was formerly a slave. He, too, is a Baptist preacher - a man of less thought perhaps than Rickmond, but of greater fluency. As a preacher he is very popular, and has a large influence. He reads and writes. He lives in Charlottesville.

Henry Smith, a black man, is a farmer and a Baptist preacher. I am not personally acquainted with him, but am told that he reads well, and it is believed he can also write. He was formerly a slave. Among his people he has much influence. He resides near Scottsville.

Spotswood Jones, a mulatto, is also a farmer and Baptist preacher. With him I have no personal acquaintance, but he is represented as being able to read well, and to write. Formerly he was a slave. Among his people in his neighborhood he exerts considerable influence. He resides at Carter's Bridge.

Emanuel Madison, a black man, formerly a slave, is a farmer. He is a prominent member of the Baptist Church, and in his neighborhood has a large influence. It is believed he can read, but he can not write. He resides near Keswick Depot.

Peter A. Cross, a quadroon, is a blacksmith. He was always free, and has some property. He is an officer in the Baptist church, and respected in the 
community. Writes his name, but I am told cannot write anything else, or even read well. He has considerable influence, and lives in Charlottesville.

Ossian Johnson, a black man, formerly a slave, but had purchased his won freedom, is also an officer in the Baptist church. He is able to read, but not to write. Among his own people he is popular, and exerts a wide influence. He resides in Charlottesville.

Fairfax Taylor, a black man, formerly a slave, freed by his own purchase, is also an officer of the Baptist Church. He has been attending the colored school in this place, and can not only read and write, but has some knowledge of grammar, which none of the others have unless it be Robert Scott. He is respected in the community, but his influence is said to be limited. He resides in Charlottesville." 


\section{Bibliography}

Primary Sources:

Albemarle County Minute Book, 1869-1874, Albemarle County Court House,

Boston School Committee Records, 1840-1890, Boston Public Library

New England Freedmen's Aid Society Records, 1862-1876, Massachusetts

Historical Society

The Reminiscences of Philena Carkin, Alderman Library, Special Collections,

University of Virginia

Records of the Bureau of Freedmen, Refugees and Abandoned Lands, National

Archives

United States Census Records, 1870, Library of Virginia

Newspapers

Charlottesville Chronicle, Charlottesville, Virginia

Southern Workman, Hampton University Archives

The Freedmen's Journal, Massachusetts Historical Society

The Planet, Library of Virginia

The True Southerner, The College of William and Mary

The Woman's Journal, Massachusetts Historical Society 
Secondary Sources:

Abrahams, Roger D. Singing the Master: The Emergence of African American Culture in the Plantation South. New York: Pantheon Books, 1992.

Ajayi, J. F. Ade, and Michael Crowder. History of West Africa. New York: Columbia University Press, 1972.

Amadiume, Ifi. Male Daughters, Female Husbands: Gender and Sex in an African Society. London: Zed Books, 1987.

Anderson, James D. The Education of Blacks in the South, 1860-1935. Chapel Hill: University of North Carolina Press, 1988.

Armstead, Myra B. Young. "Lord, Please Don't Take Me in August": African Americans in Newport and Saratoga Springs, 1870-1930. Urbana: University of Illinois Press, 1999.

Ash, Stephen V. Middle Tennessee Society Transformed, 1860-1870: War and Peace in the Upper South. Baton Rouge: Louisiana State University, 1988.

Ayers, Edward L. The Promise of the New South: Life After Reconstruction. New York: Oxford University Press, 1992.

Bardaglio, Peter. Reconstructing the Household: Families, Sex, and the Law in The Nineteenth Century South. Chapel Hill: University of North Carolina Press, 1995.

Benedict, Michael Les. A Compromise of Principle: Congressional Republicans and Reconstruction, 1863-69. New York: Norton, 1974.

Berlin, Ira, et al, editors. Freedom: A Documentary History of Emancipation, 1861-1867. Series 1, vol. 2, The Wartime Genesis of Free Labor: The Upper South. New York: Cambridge University Press, 1993.

Billings, Dwight B. Jr. Planters and The Making of a New South: Class, Politics, and Development in North Carolina, 1865-1900. Chapel Hill: University of North Carolina Press, 1979. 
Billington, Ray Allen, editor. The Journal of Charlotte L. Forten. New York: Collier Books, 1953.

Blair, William. Virginia's Private War: Feeding Body and Soul in the Confederacy, 1861-1865. New York: Oxford University Press, 1998.

Blassingame, John W. The Slave Community: Plantation Life in the Antebellum South. New York: Oxford University Press, 1972.

Boles, John B. The South Through Time: A History of an American Region. Volumes I, II. New Jersey: Prentice Hall, 1999.

Boney, F. N. John Letcher of Virginia: The Story of Virginia's Civil War Governor. Tuscaloosa: University of Alabama Press, 1966.

Boone, Sylvia Ardyn. Radiance from the Waters: Ideals of Feminine Beauty in Mende Art. New Haven: Yale University Press, 1986.

Breen, T. H. Tobacco Culture: The Mentality of the Great Tidewater Planters on the Eve of Revolution. Princeton: Princeton University press, 1985.

, and Stephen Innes. "Myne Owne Ground": Race and Freedom on Virginia's Eastern Shore, 1640-1676. New York: Oxford University Press, 1980.

Brown, Kathleen M. Good Wives, Nasty Wenches, \& Anxious Patriarchs: Gender, Race, and Power in Colonial Virginia. Chapel Hill: University Press of North Carolina, 1996.

Brown, Richard D. Knowledge is Power: The Diffusion of Information in Early America, 1700-1865. New York: Oxford University Press, 1989.

Buck, J.L. Blair. The Developement of Public Schools in Virginia, 1607-1952. Richmond: State Board of Education, 1952.

Bullock, Henry Allen. A History of Negro Education in the South. Cambridge: Harvard University Press, 1967.

Burton, Orville, Vernon. In My Father's House are Many Mansions: Family and Community in Edgefield, South Carolina. Chapel Hill: University of North Carolina Press, 1985.

and Robert C. McMath, Jr., ed., Class, Conflict, and Consensus:

Antebellum Southern Community Studies. Westport, Conn: Greenwood, 1981. 
- Toward a New South? Studies in Post-Civil War Southern

Communities. Westport, CT: Greenwood, 1982.

Bushnell, David. The Manahoac Tribes of Virginia, 1608. Washington, D. C.: Smithsonian Institution, 1935.

Butchart, Ronald E. Northern Schools, Southern Blacks, and Reconstruction: Freedmen's Education, 1862-1875. (Westport, Conn.: Greenwood Press, 1980).

Carter, Dan T. When the War Was Over: The Failure of Self- Reconstruction in the South, 1865-1867. Baton rouge: Louisiana State University Press, 1985.

Chesson, Michael B. Richmond After the War 1865-1890. Richmond: Virginia State Library, 1981.

Clinton, Catherine. Fannie Kemble's Civil Wars. New York: Simon and Schuster, 2000.

Clinton, Catherine and Nina Silber, editors. Divided Houses: Gender and the Civil War. New York: Oxford University Press, 1992.

Collins, Patricia Hill. Black Feminist Thought: Knowledge, Consciousness, and the Politics of Empowerment. New York: Routledge, 1990.

Cornelius, Janet Duitsman. When I Can Read My Title Clear: Literacy, Slavery, and Religion in the Antebellum South. Columbia: The University of South Carolina Press, 1991.

Cott, Nancy. The Bonds of Womanhood: Woman's Sphere in New England. New Haven: Yale University Press, 1978.

Cross-White, Agnes. Images of America: Charlottesville: The African American Community. New Hampshire: Arcadia Publishing, 1998.

Dailey, Jane. Before Jim Crow: The Politics of Race in Post-Emancipation Virginia. Chapel Hill: The University Press of North Carolina, 2000.

Davis, Angela Y. Women, Race, and Class. New York: Vintage Books, 1981.

Davis, Richard Beale. Intellectual Life in Jefferson's Virginia, 1790-1830. Chapel Hill: University of North Carolina Press, 1946.

Donald, David. The Politics of Reconstruction, 1863-1867. Cambridge: Harvard University Press, 1984. 
Edwards, Laura. Gendered Strife and Confusion: The Political Culture of Reconstruction. Urbana: University of Illinois Press, 1997.

Engs, Robert. Freedom's First Generation: Black Hampton, Virginia, 1861-1890. Philadelphia: University of Pennsylvania Press, 1979.

Escott, Paul D. Slavery Remembered: A Record of Twentieth-Century Slave Narratives. Chapel Hill: University of North Carolina Press, 1979.

Faust, Drew Gilpin. Mothers of Invention: Women of the Slaveholding South in the American Civil War. Chapel Hill: University of North Carolina Press, 1996.

. The Creation of Confederate Nationalism: Ideology and Identity in the Civil War South. Baton Rouge: Louisiana State University Press, 1988.

Fisher, Miles Mark. Negro Slave Songs in the United States. New York: First Carol Publishing, 1990.

Foner, Eric. Freedom's Lawmaker's: A Directory of Black Officeholders During Reconstruction. New York: Oxford University Press, 1993.

Reconstruction: America's Unfinished Revolution. New York:

Harper and Row, 1988.

. Nothing but Freedom: Emancipation and its Legacy. Baton Rouge:

Louisiana State University Press, 1983.

Foner, Philip S., editor. Frederick Douglass on Women's Rights. New York: Da Capo Press, 1992.

Foster, Frances Smith, editor. A Brighter Coming Day: A Frances Ellen Watkins Harper Reader. New York: The Feminist Press @ The City University of New York, 1990.

Foster, Gaines M. Ghosts of the Confederacy: Defeat, the Lost Cause, and the Emergence of the New South, 1865-1913. New York: Oxford University Press, 1987.

Fox-Genovese, Elizabeth. Within the Plantation Household: Black and White Women of the Old South. Chapel Hill: University of North Carolina Press, 1988.

Franklin, John Hope. Reconstruction: After the Civil War. Chicago: The University of Chicago Press, 1961, 1994. 
, and Alfred A. Moss, Jr. From Slavery to Freedom: A History of

African Americans. New York: McGraw-Hill, 1998.

Gaston, Paul M. The New South Creed: A Study in Mythmaking. New York: Knopf, 1970.

Genovese, Eugene. Roll, Jordan, Roll: The World the Slaves Made. New York: Vintage Books, 1976.

Gordon, Ann D. with Bettye Collier-Thomas, editors. African American Women and the Vote, 1837-1965. Amherst: University of Massachusetts Press, 1997.

Gray, Lewis C. History of Agriculture in the Southern United States to 1860. 2 vols. Washington, D. C.: Carnegie Institution of Washington, 1933.

Greene, Lorenzo G. and Carter G. Woodson. The Negro Wage Earner. Washington, D. C.: Association for the Study of Negro Life and History, 1930.

Greenwood, Janette. Bittersweet Legacy: The Black and White Better Classes of Charlotte, North Carolina. Chapel Hill: University of North Carolina Press, 1994.

Hahn, Steven. The Roots of Southern Populism: Yeoman Farmers and the Transformation of the Georgia Upcountry, 1850-1890. New York: Oxford University Press, 1983.

Hine, Darlene Clark and Kathleen Thompson. A Shining Thread of Hope: The History of Black Women in America. New York: Broadway Books, 1998.

Holt, Thomas. Black over White: Negro Political Leadership in South Carolina during Reconstruction. Urbana: University of Illinois Press, 1977.

Horst, S. L. Education for Manhood: The Education of Blacks in Virginia during the Civil War. Lanham, MD: University Press of America, 1987.

Horton, James Oliver and Lois E. Horton. Black Bostonians: Family Life and Community Struggle in the Antebellum North. New York: Holmes and Meier, 1979.

Hubbard, Dolan, editor. Recovered Writers/ Recovered Texts: Race, Class, and Gender in Black Women's Literature. Knoxville: The University of Tennessee Press, 1997.

Hunter, Tera W. To 'Joy My Freedom: Southern Black Women's Lives and Labors After the Civil War. Cambridge: Harvard University Press, 1997. 
Irwin, Marjorie Felice. The Negro in Charlottesville and Albemarle County. 1929.

Isaac, Rhys. The Transformation of Virginia, 1740-1790. Chapel Hill: University of North Carolina Press, 1982.

Jackson, Luther P. Negro Office-Holders in Virginia, 1865-1895. Norfolk: The Guide Quality Press, 1945.

Jeffrey, Julie Roy. The Great Silent Army of Abolitionism: Ordinary Women in the Antislavery Movement. Chapel Hill: University Press of North Carolina, 1998.

Jones, Jacqueline. Labor of Love, Labor of Sorrow: Black Women, Work and the Family, From Slavery to the Present. New York: Vintage, 1985.

Soldiers of Light and Love: Northern Teachers and Georgia Blacks, 1865-1873. Athens: The University of Georgia Press, 1992.

Jordan, Ervin L. Charlottesville and the University of Virginia in the Civil War. Lynchburg: H. E. Howard, 1988.

Kerr-Ritchie, Jeffrey R. Freedpeople in the Tobacco South: Virginia 1860-1900. Chapel Hill: The University of North Carolina Press, 1999.

King, Wilma, editor. A Northern Woman in the Plantation South: Letters of Tryphena Blanche Holder Fox, 1856-1876. Columbia: University of South Carolina Press, 1993.

Kolchin, Peter. American Slavery, 1619-1877. New York: Hill and Wang, 1993.

Levine, Lawrence W. Black Culture and Black Consciousness: Afro- American Folk Thought from Slavery to Freedom. New York: Oxford University Press, 1977.

Link, Arthur A. A Hard Country and a Lonely Place: Schooling, Society, and Reform in Rural Virginia, 1870-1920. Chapel Hill: University of North Carolina Press, 1986.

Litwack, Leon. Been in the Storm So Long: The Aftermath of Slavery. New York: Knopf, 1979.

Loewenberg, Bert James and Ruth Bogin. Black Women in Nineteenth-Century American Life. University Park: Pennsylvania State University Press, 1976. 
Logan, Rayford W. The Negro in American Life and Thought: The Nadir, 18771901. New York: Collier, 1954.

Lowe, Richard. Republicans and Reconstruction in Virginia, 1856-1870.

Charlottesville: The University Press of Virginia, 1991.

McColley, Robert. Slavery and Jeffersonian Virginia, 2nd edition. Urbana: University of Illinois Press, 1973.

McKinney, Richard I. A History of the First Baptist Church, 1863-1980.

Charlottesville: West Main Street, 1981.

McKitrick, Eric. L. Andrew Johnson and Reconstruction. Chicago: University of Chicago Press, 1960.

McLaurin, Melton A. Celia: A Slave. Athens, University of Georgia Press, 1991.

McPherson, James M. Ordeal by Fire: The Civil War and Reconstruction. New York: Knopf, 1982.

Moore, John Hammond. Albemarle, Jefferson's County, 1727-1976.

Charlottesville: Albemarle County Historical Society, 1976.

Morgan, Lynda J. Emancipation in Virginia's Tobacco Belt, 1850-1870. Athens: The University of Georgia Press, 1992.

Morris, Robert C. Reading, 'Riting and Reconstruction: The Education of Freedmen in the South, 1861-1870. Chicago: University of Chicago Press, 1981.

Morton, Patricia. Disfigured Images: The Historical Assault on Afro-American Women. Westport: Praeger, 1991.

Nieman, Donald G., editor. Freedom, Racism and Reconstruction: Collected Writings of LaWanda Cox. Athens: University of Georgia Press, 1997.

Ownby, Ted. Subduing Satan: Religion, Recreation, and Manhood in the Rural South, 1865-1920. Chapel Hill: University of North Carolina Press, 1990.

Perdue, Charles L. Thomas E. Barden and Robert Phillips. Weevils in the Wheat: Interviews of Virginia's Ex-Slaves. Charlottesville: University Press of Virginia, 1976. 
Perman, Michael. Reunion Without Compromise: The South and Reconstruction, 1865-1868. New York: Cambridge University Press, 1973.

Rable, George, C. Civil Wars: Women and the Crisis of Southern Nationalism. Urbana: University of Illinois Press, 1989.

Raboteau, Albert J. Slave Religion: The Invisible Institution in the Antebellum South. New York: Oxford University Press, 1978.

Rachleff, Peter J. Black Labor in the South: Richmond, Virginia, 1865-1890. Urbana: University of Illinois Press, 1984.

Ransom, Roger L. and Richard Sutch. One Kind of Freedom: The Economic Consequences of Emancipation. New York: Cambridge University Press, 1977.

Reilly, Wayne E., editor. Sarah Jane Foster: Teacher of the Freedmen.

Charlottesville: University of Virginia, 1990.

Romero, Patricia w. and Willie Lee Rose, editors. Reminiscences of My Life: A Black Woman's Civil War Memoirs. New York: Markus Wiener Publishing, 1998.

Rose, Willie Lee. Rehearsal for Reconstruction: The Port Royal Experiment Indianapolis: Bobbs-Merrill, 1964.

Schwalm, Leslie A. A Hard Fight For We: Women's Transition from Slavery to Freedom in South Carolina. Urbana: University of Illinois Press, 1997.

Schwartz, Marie Jenkins. Born in Bondage: Growing Up Enslaved in the Antebellum South. Cambridge: Harvard University Press, 2000.

Scott, James C. Domination and the Arts of Resistance: Hidden Transcripts. New Haven: Yale University Press, 1988.

Scott, Anne Firor. The Southern Lady: From Pedestal to Politics, 1830-1930. Chicago: University of Chicago Press (1970)

Sobel, Mechal. The World They Made Together: Black and White Values in Eighteenth-Century Chesapeake Society. Ithaca, N. Y.: Cornell University Press, 1987.

Sterling, Dorothy, editor. We Are Your Sisters: Black Women in the NineteenthCentury. New York: W. W. Norton \& Company, 1984. 
Stevenson, Brenda E. Life in Black \& White: Family and Community in the Slave South. New York: Oxford University Press, 1996.

Summers, Mark W. Railroads, Reconstruction, and the Gospel of Prosperity: Aid Under the Radical Republicans, 1865-1877. Princeton: Princeton University Press, 1984.

Taylor, Alrutheus A. The Negro in the Reconstruction of Virginia. Washington, D.C. 1926.

Terborg-Penn, Rosalyn. African-American Women in the Struggle for the Vote, 1850-1920. Bloomington: Indiana University Press, 1998.

Trelease, Allen W. White Terror: The Ku Klux Klan Conspiracy and Southern Reconstruction. New York: Harper \& Row, 1971.

Varon, Elizabeth R. We Mean to Be Counted: White Women and Politics in Antebellum Virginia. Chapel Hill: University of North Carolina Press, 1998.

Wade, Richard C. Slavery in the Cities: The South 1820-1860. New York: Oxford University Press, 1964.

Wagoner, Jennings and Urvin Wayne. American Education: A History. Boston: McGraw Hill, 2000.

Walker, Margaret. Jubilee. New York: Houghton Mifflin Company, 1966.

White, Deborah Gray. Ar'n't I a Woman?: Female Slaves in the Plantation South. New York: W. W. Norton \& Co., 1985, 1999.

Williamson, Joe. After Slavery: The Negro in South Carolina During Reconstruction, 1861-1877. Chapel Hill: University of North Carolina, 1965.

Wilson, Charles Reagan. Baptized in Blood: The Religion of the Lost Cause, 1865-1920. Athens: University of Georgia Press, 1980.

Woodward, Comer Vann. The Burden of Southern History. Baton Rouge: Louisiana State University Press, 1968, 1993.

Woodward, C. V. The Private Mary Chesnutt: The Unpublished Civil War Diaries. New York: Oxford University Press, 1984.

Wright, Gavin. The Political Economy of the Cotton South: Households, Markets, and Wealth in the Nineteenth Century. New York: Norton, 1978. 
Writer's Program of the Work Projects Administration in the State of Virginia. The Negro in Virginia. New York: Hastings Publishers, 1940.

Wyatt-Brown, Bertram. Southern Honor: Ethics and Behavior in the Old South. New York: Oxford University Press, 1982.

Wynes, Charles E. Race Relations in Virginia, 1870-1902. Charlottesville: University Press of Virginia, 1961.

Yellin, Jean Fagan, editor. Incidents in the Life of a slave Girl Written by Herself. Cambridge: Harvard University Press, 1987.

Theses and Dissertations:

Branscome, James. "Impressment in the State of Virginia During the Civil War." M. A. thesis, Wake Forest University, 1976.

Brooks, Albert. "Education of Negroes in Virginia Prior to 1861." M. A. thesis, Howard University, 1938.

Brown, Emma. "A Study of the Influence of the Philosophies of Accommodation and Protest on Five Colleges Established in Virginia for Negroes, 1865-1940." D. Ed. Dissertation, Columbia University, 1967.

Carmichael, Peter S. "The Last Generation: Sons of Virginia Slaveholders and the Creation of a Confederate Identity, 1850-1865." Ph.D. dissertation, Pennsylvania State University, 1996.

Coleman, Annie C. "The Negro in Virginia and South Carolina, 1861 to 1877, as seen by contemporary Observers and Newspapers and by Historians." M. A. thesis, Virginia State University, 1967.

Echols, James Robert. "An Analysis of Higher Education for Negroes in the Commonwealth of Virginia." Ph.D. dissertation, University of Virginia, 1948.

Fields, Emmett B. "The Agricultural Population of Virginia, 1850-1860." Ph.D. dissertation, Vanderbilt University, 1953.

Florence, Charles W. "Training of Colored Teachers for the Public Schools of Virginia." M. A. thesis, University of Pittsburgh, 1923.

Golden, Alan Lawrence. "The Secession Crisis in Virginia: A Critical Study of Argument." Ph.D. dissertation, Ohio State University, 1990. 
Hartzell, Lawrence. "The Exploration of Freedom in Black Petersburg, 18651902.” Ph.D. dissertation, University of Virginia, 1991.

Hickin, Patricia. “Antislavery in Virginia, 1832-1860.” Ph.D. dissertation, University of Virginia, 1968.

Horst, Samel Levi. Education for Manhood: The Education of Blacks in Virginia during the Civil War. Ph.D. dissertation, University of Virginia, 1977.

Hunt, Patricia K., "The Influence of Fashion on the Dress of African American Women in Georgia: 1870-1915." Ph.D. dissertation, Ohio State University, 1990.

Johnston, James Hugo. "Race Relations in Virginia and Miscegenation in the South, 1776-1860.” Ph.D. dissertation, University of Chicago, 1937.

Jones, Newton Bond. "Charlottesville and Albemarle County, 1819-1860." Ph.D. dissertation, University of Virginia, 1950.

Joray, Thomas Michael. "Blueprint of the Virginia State Freedmen's Bureau School System." M. A. thesis, University of Maryland, 1976.

Krug, Donna. "The Folks Back Home: The Confederate Home Front during the Civil War.” Ph.D. dissertation, University of California, Irvine, 1990.

Lloyd, Hermine Elizabeth. "History of the Public Education of the Negro in Virginia." M. A. thesis, Howard University, 1936.

Mansfield, Betty. "That Fateful Class: Black Teachers of Virginia's Freedmen, 1861-1882.” Ph.D. dissertation, Catholic University of America, 1980.

McColley, Robert McNair. "Gentlemen and Slavery in Jefferson's Virginia." Ph.D. dissertation, University of California, Berkeley, 1961.

McConnell, John Preston. "Negroes and Their Treatment in Virginia from 1865 to 1867." Ph.D. dissertation, University of Virginia, 1904.

McFarland, George M. "The Extension of Democracy in Virginia, 1850-1895." Ph.D. dissertation, Princeton University, 1934.

O' Brien, John Thomas, Jr., "From Bondage to Citizenship: The Richmond Black Community, 1865-1867." Ph.D. dissertation, University of Rochester, 1974. 
Owens, Martha Warren. "The Development of Public Schools for Negroes in Richmond, Virginia, 1865-1900". M. S. thesis, Virginia State College, 1947.

Pleck, Elizabeth Hafkin. "Black Migration to Boston in the Late Nineteenth Century." Ph.D. dissertation, Brandeis University, 1973.

Richey, Thomas Webster. "The Virginia State Convention of 1861 and Virginia Secession." Ph.D. dissertation, University of Georgia, 1990.

Shultz, Jane E. "Women at the Front: Gender and Genre in Literature of the American Civil War." Ph.D. dissertation, University of Michigan, 1988.

Simkins, Anna A., "The Functional and Symbolic Roles of Hair and Headgear among Afro American Women: A Cultural Perspective" Ph.D. dissertation, University of North Carolina, 1982.

Stauffenberg, Anne Lenore. "Albemarle County, Virginia, 1850-1870: An Economic Survey Based on the U. S. Census." M. A. thesis, University of Virginia, 1973.

Stennette, Janice Schmid. “Teaching for the Freedmen's Bureau." Ph.D. dissertation, University of Virginia, 1996.

Vance, Joseph Carroll. "The Negro in the Reconstruction of Albemarle County, Virginia." M. A. thesis, University of Virginia, 1953.

Ware, Lydia J. "Dress of the African American Woman in Slavery and Freedom, 1500-1935." Ph.D. dissertation, Purdue University, 1981.

Wolfe, Allis. "Women Who Dared: Northern Teachers of the Southern Freedmen, 1862-1872." Ph.D. dissertation, City University of New York, 1982.

Wright, Dianne Swann. "A Way Out of No Way: Learning the Ways of Freedom in the New South, 1865-1930. Ph.D. dissertation, University of Virginia, 2000.

Wynes, Charles Eldridge. "Race Relations in Virginia, 1870-1902.” Ph.D. dissertation University of Virginia, 1960.

Journal Articles 
Alston, Lee J. and Kyle D. Kauffman. "Up, Down, and Off the Agricultural Ladder: New Evidence and Implications of Agricultural Mobility for Blacks in the Postbellum South." Agricultural History, 72, Spring, 263-79.

Anderson, James D. "The Hampton Model of Normal School Industrial Education, 1868-1900," in New Perspectives on Black Educational History, Vincent P. Franklin and James D. Anderson, editors, 1978.

Aucoin, Brent J. "Thomas Goode Jones (1844-1914) and African American Civil Rights in the New South". Historian, 60, Winter, 257-71.

Barr, Alwyn. "Black Urban Churches on the Southern Frontier, 1865-1900." Journal of Negro History, 82, Fall (1997), 368-83.

Blyn, Robin. "Memory Under Reconstruction: Beloved and the Fugitive Past." Arizona Quarterly, 54, Winter, 111-40.

Boyd, Herb. Radicalism and Resistance: The Evolution of Black Radical Thought. Black Scholar, 28, Spring, 43-53.

Burton, Orville Vernon. African American Status and Identity in a Post bellum community: An Analysis of the Manuscript Census Returns (Edgefield District, S. C.)", Agricultural History, 72, Spring, 213-40.

Butchart, Ronald E. "Recruits to the "Army of Civilization": Gender, Race, Class, and the Freedmen's Teachers, 1862-1875," Journal of Education 172:3 (1990), 76-87.

"Outthinking and Outflanking the Owners of the World": A Historiography of the African American Struggle for Education," History of Education Quarterly. 28 (Fall 1988): 333-66.

. "They Gave Them Schools...But Why Only Schools?" History of Education Quarterly (Winter 1994): 619-25.

Cobb, James C. "Beyond Planters and Industrialists: A New Perspective on the New South," Journal of Southern History, 54 (February 1988), 45-68.

De Cunzo, Lu Ann. A Future After Freedom, Historical Archaeology, 32, no. 1 pp. $42-54$.

Edwards, Laura. "The Problem of Dependency: African Americans, Labor Relations, and the Law in the Nineteenth-Century South." Agricultural History, 72, Spring, 313-40. 
Ellenberg, George B. African Americans, Mules, and the Southern Mindscape, 1850-1950. Agricultural History, 72, Spring, 381-98.

Ferleger, Louis. The Problem of "Labor" in the Post -Reconstruction Louisiana Sugar Industry. Agricultural History, 72, Spring, 140-58.

Ferguson, Dean. “'Living by Means Unknown to their Neighbors': The Informal Economy of Louisville's Blacks, 1865-1880." Filson Club Historical Quarterly, 72, Oct. 357-78.

Fitzgerald, Michael W. "Republican Factionalism and Black Empowerment: The Spencer-Warner Controversy and Alabama Reconstruction, 1868-1880." Journal of Southern History, 64, August 473-94.

Ford, Lacy K. "Rednecks and Merchants: Economic Development and Social Tensions in the South Carolina Upcountry, 1865-1900," Journal of American History, 71 (September 1984), 294-318.

Formwalt, Lee W. "Moving in 'That Strange Land of Shadows': African American Mobility and persistence n Post-Civil War Southwest Georgia." Georgia Historical Quarterly, 82, Fall, 507-32.

Forsythe, Harold S. "'But My Friends are Poor; Ross Hamilton and Freedpeople's Politics in Mecklenburg County, Virginia, 1869-1901." Virginia Magazine History and Biography, v. 105, Autumn, 409-38.

Franklin, Jimmie Lewis. 'Black Southerners, Shared Experience, and Place: A Reflection" The Journal of Southern History (volume LX, no. 1, February 1994).

Fryer, Peter. "The 'Discovery' and Appropriation of African Music and Dance." Race and Class, 39, January-March, 1-20.

Gilmore, William. "Elementary Literacy on the Eve of the Industrial Revolution: Trends in Rural New England 1760-1830" Proceedings of the American Antiquarian Society 92, part 1 (1982): 87-178.

Harris, Peggy G. "Beyond the Marginality Thesis: The Acquisition and Loss of Land by African Americans in Georgia, 1880-1930." Agricultural History, 72, Spring 241-62.

Hays, Christopher K. "The African American Struggle for Equality and Justice in Cairo, Illinois, 1865-1900." Illinois Historical Journal, 90, Winter (1997), 265-84.

Hoffert, S. D. "Yankee Schoolmarms and the Domestication of the South." Southern Studies, 24 188-201. 
Hunt, Patricia K. "The Struggle to Achieve Individual Expression through Clothing and Adornment: African American Women Under and After Slavery" in Discovering the Women in Slavery: Emancipating Perspectives on the American Past, edited by Patricia Morton (1996) University of Georgia Press, 227-240.

Hunt, Thomas C. and Jennings L. Wagoner, Jr. "Race Religion, and Redemption: William Henry Ruffner and the Moral Foundations of Education in Virginia." American Presbyterians, 66:1 (Spring 1988).

Irwin, James R. and Anthony Patrick O'Brien. "Where Have All the Sharecroppers Gone?' Black Occupations in Postbellum Mississippi." Agricultural History, 72, Spring, 280-97.

Israel, Charles A. "From Biracial to Segregated Churches: Black and White Protestants in Houston, Texas, 1840-1870." Southwestern Historical Quarterly, 101, Spring 1992, 428-58.

Jennings, Thelma. "'Us Colored Women Had to Go through a Plenty': Sexual Exploitation of African American Slave Women." Journal of Women's History 1 (Winter 1990): 45-74.

Johansen, Mary Carroll. "'Intelligence, Though Overlooked': Education for Black Women in the Upper South, 1800-1840." Maryland Historical Magazine, 93, Winter, 443-65.

Kimball, Greg D. "African, American, and Virginia: The Shaping of Black Memory in Antebellum Virginia, 1790-1860." In Where these Memories Grow: History, Memory, and Southern Identity, edited by W. Fitzhugh Brundage (Chapel Hill: University of North Carolina Press), pp. 57-77.

Landsmark, Theodore C. "Comments on African American Contributions to American Material Life." Winterthur Port, 33, Winter, 261-82.

Lichtenstein, Alex. "Was the Emancipated Slave a Proletarian?" Reviews in American History, 26, March 124-45.

Morris, Christopher. "The Articulation of Two Worlds: The Master-Slave Relationship Reconsidered.” Journal of American History, 85, Dec. 982-1007.

McPherson, James M. "The New Puritanism: Values and Goals of Freedmen's Education in America." Lawrence Stone, editor, The University in Society. Princeton, Princeton University Press, 1974: 611-42. 
Neary, Margaret R. "Some Aspects of Negro Social Life in Richmond, Virginia, 1865-1880." The Maryland Historian I, Fall 1970.

Ochiltree, Ian D. "A Just and Self-Respecting System"? Black Independence, Sharecropping, and Paternalistic Relations in the American South and South Africa." Agricultural History, (72), 352-80.

Okonjo, Kamene. "The Dual-Sex Political system in Operation: Igbo women and Community Politcs in Midwestern Nigeria." In Women in Africa: Studies in Social and Economic Change, edited by Nancy Hafkin and Edna Bay, 45-58. Stanford: Stanford University Press, 1976.

Onuf, Peter S. "To Declare them a Free and independent People"; Race, Slavery, and National Identity in Jefferson's Thought." Journal of the Early Republic, 18, Spring: 1-46.

Penningroth, Dylan. "Slavery, Freedom, and Social claims to Property among African Americans in Liberty County, Georgia, 1850-1880." The Journal of American History, September 1997: 405-35.

Rabinowitz, Howard. "Half a Loaf: The Shift from White to Black Teachers in the Negro Schools of the Urban South, 1865-1890." The Journal of Southern History, (Nov. 1974): 565-94.

Schulman, Gayle. "The Gibbons Family. The Magazine of Albemarle County History, (55), 1997, pp. 61-94.

Schultz, Mark R. "The Dream Realized? African American Land Ownership in Central Georgia Between Reconstruction and World War Two." Agricultural History, 72, Spring, 298-312.

Schwalm, Leslie A. "Sweet Dreams of Freedom"; Freedwomen's Reconstruction of Life and Labor in Lowcountry South Carolina." Journal of Women's History, 9, Spring, 9-38.

Sklar, Kathryn Kish. "The Schooling of Girls and Changing Community Values in Massachusetts Towns, 1750-1820." The History of Education Quarterly, Winter 1993: 511-41.

Smith, John David. "The Work It Did Not Do Because It Could Not"; Georgia and the "New" Freedmen's Bureau Historiography." Georgia Historical Quarterly, 82, Summer, 331-49.

Stanley, Amy Dru. "Beggars Can't Be Choosers: Compulsion and Contract in Postbellum America." The Journal of American History, March 1992: 1265-93. 
Stanton, Lucia. "Monticello to Main Street: The Hemings Family and Charlottesville." The Magazine of Albemarle County History, volume 55, 1997: 95-126.

Tarter, Brent. "The New Virginia Bookshelf." The Virginia Magazine of History and Biography, volume 104:1 (Winter 1996): 7-103.

Vance, Joseph C. "Freedmen's Schools in Albemarle County During Reconstruction." The Virginia Magazine of History and Biography, volume 61, 1953: $430-38$.

. "Race Relations in Albemarle During Reconstruction." Magazine of Albemarle County History, volume 23, 1956: 23-45.

Vandal, Gilles. "Property Offenses, Social Tension and Racial Antagonism in Post-Civil War Rural Louisiana." Journal of Social History, 31, Fall (1997), 12753.

Von Daccke, Kirt. "Slaves Without Masters? The Butler Family of Albemarle County, 1780-1860." The Magazine of Albemarle County History, volume55, 1997: $39-60$.

Wagoner, Jennings, "The American Compromise: Charles W. Eliot, Black Education, and The New South." Edited by Ronald Goodenow and Arthur White in Education and the Rise of the New South. Boston: G. K. Hall, 1981.

Wolf, Kurt J. "Laura M. Towne and the Freed People of South Carolina, 18621901." South Carolina Historical Magazine, v.98, Oct. 375-405.

Woodman, Harold D. "Sequel to Slavery: The New History Views the Postbellum South." Journal of Southern History, volume 43 (November 1977), 523-54. 